\title{
10
}

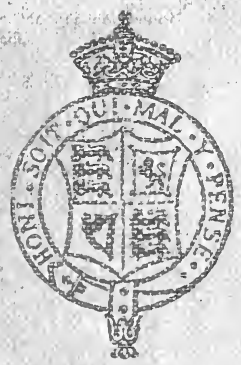

\section{OLD TESTAMENT}

\section{NARRATHVES}




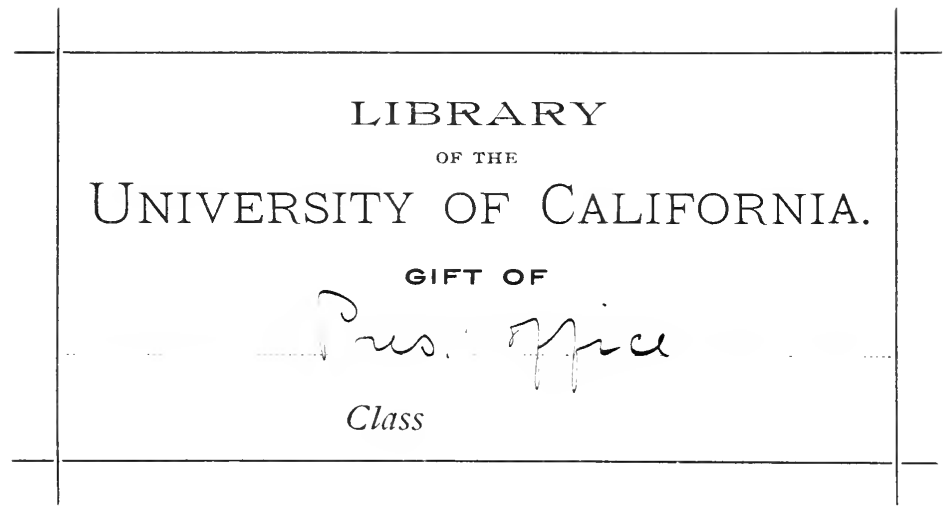





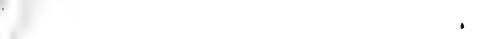


Digitized by the Internet Archive in 2007 with funding from

Microsoft Corporation 
. 


\section{OLD TESTAMENT \\ N A R R A T I VES}

SELECTED AND EDITED

BY

\section{GEORGE HENRY NETTLETON}

Assistant Professor of English in the Sheffield

Scientific School of Yale University
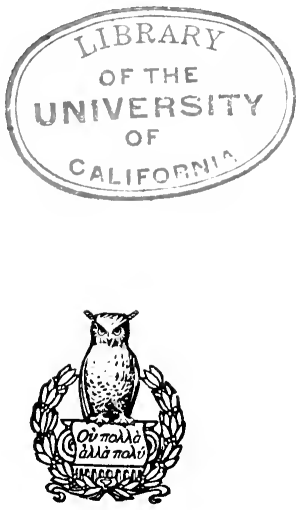

NEW YORK

HENRY HOLT AND COMPANY

I 9 I I 


$$
\beta^{5} i^{4 !}
$$

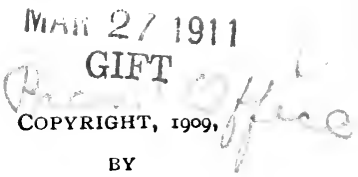

HENRY HOLT AND COMPANY

QUINN \& BODEN COMPANY PRESS

RAHWAY, N. J. 
To

IIIS IISotber 


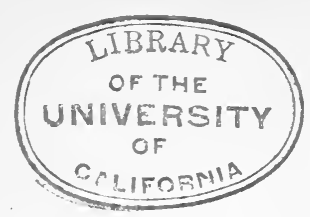

\section{PREFACE}

THIS book aims to present a considerable body of Old Testament narrative in a form convenient both for the general reader and for the student of literature. Practical experience with college classes has confirmed my belief that literary study of the Bible should begin with the stories of the Old Testament. These give at once an effective introduction to the vocabulary and phrase of the Bible, an explanation of many of the most frequent Biblical allusions in secular literature, and a basis for study of literary art in its most popular form.

The choice of selections has been difficult. The general aim has been to select passages interesting in themselves and important in the development of the whole Hebrew record. Obviously it is impossible to include within the limits of three hundred pages every incident that commends itself to an editor or critic. I shall be amply satisfied if the book meets in reasonable measure the need which I have felt in my own classes for a text of Hebrew narrative compact in form, yet somewhat comprehensive in scope. In the belief that the general reader should study the Bible itself rather than about it, I have adhered strictly to the simple Bible text, with no summaries of story, and with no other notes than the few brackets which explain the 
meaning of significant Hebrew proper names or of obsolete English words.

The text follows the King James or Authorised Version for reasons fully set forth in the Introduction. It differs from the usual form only in the neglect of italics, in the omission of verse-divisions, in slight changes in capitalization due chiefly to that omission, and in the adoption of convenient paragraphs. It is now commonly admitted that the ordinary text of the Bible recognizes somewhat arbitrary distinctions in chapter and verse form, but fails to recognize fully more vital distinctions of literary structure and style. The division into verses, adopted in the Genevan Bible for ease of reference, is somewhat of an obstacle to modern readers. The Revised Version, indeed, though it retains verse numerals in the margin, groups verses in paragraphs. The use of italics to indicate additions in the translation to the original text concerns the scholar rather than the general reader. In the various stages of manuscript and proof, my text has been collated with eight modern editions of the King James Version. Modern texts show not a little correction and revision of the early editions. Both issues of the I6I I edition contain misprints, and the "Wicked Bible" of 1632 , which omitted the word " not" from the seventh commandment, and the "Vinegar Bible" of I7 I7, which printed "Vinegar" for "Vineyard" in the heading of one of the parables, are striking instances of typographical errors. Modern editions themselves do not conform to an absolute standard. No two of the eight which I collated are absolutely identical. Sometimes the 
differences are intentional, as in the modernization of spelling - " plaster" for " plaister," "basin " for " bason," " assuaged " for "asswaged." I have preferred to retain the slightly archaic flavor in diction. Sometimes the differences seem accidental, as in editions which in a hundred pages differ only in a single comma or semicolon. In the absence of any universally accepted standard text of the Authorised Version, I have preferred the "Oxford text." Other good texts are those of the so-called "Speaker's Commentary" and of the Cambridge Paragraph Bible, edited by Dr. Scrivener.

In the Introduction, I have tried to indicate briefly the processes by which the Bible has come into its modern form. I have attempted to make accessible the chief facts drawn from some scores of general and special authorities in fields in which I can make no pretence to original scholarship. Of the more general and popular works which I have found helpful I wish to mention the following: A General View of the History of the English Bible, by Brooke F. Westcott, D.D.; The History of the English Bible, by W. F. Moulton, D.D.; The Literary Man's Bible, by W. L. Courtney, LL.D.; How We Got Our Bible, by J. Paterson Smyth; The Bible as English Literature, by Professor J. H. Gardiner. It is unnecessary to enumerate the numerous works of specialists by which I have tried to check statements of fact and to reconcile frequent discrepancies. I am indebted to Professor C. C. Torrey, of Yale, for helpful suggestions which accompanied his reading of the Introduction, both in manuscript and in proof.

The selections in this volume cover the recom- 
mendation adopted in New York City, February 22, I909, by the National Conference on Uniform Entrance Requirements in English, in the following form: "The Old Testament, comprising at least the chief narrative episodes in Genesis, Exodus, Joshua, Judges, Samuel, Kings, and Daniel, together with the books of Ruth and Esther." This action of the National Conference has deep significance. For years the ignorance of the Bible on the part of students in school and college has attracted constantly increasing attention. In his vigorous leaflet, Why Not the Bible? (November I, 1906), Professor William Lyon Phelps, of Yale, put the case tersely. In heading with the Old Testament its list of books for school reading, the National Conference now publicly emphasizes the importance to every student of knowledge of the Bible as literature. Without forgetting many who have worked in a common cause, I cannot fail to mention the service of Professor Wilbur L. Cross, of Yale, chairman of the important committee which has dealt with the revision of college entrance requirements.

Yale University, March 17 , 8909. 


\section{CONTENTS}

SELECTION

PAGE

I. The Creation : $\cdot$ •

Genesis i.-ii. 3.

II. The Garden of EdeN .

Genesis ii. 4-iii.

III. Cain and Abel • • • • • • • $\quad$ • 8

Genesis iv. I-r5.

IV. The Flood •

Genesis vi. 5-ix. 17 .

V. The Tower of BAbel . • . . • • 16

Genesis xi. I-9.

VI. Abraham :

(a) The Call of Abraham . . . . . I7

Genesis xii. 1-7.

(b) The Covenant with Abraham . . 18

Genesis xvii. $\mathbf{I}-8$.

VII. The Destruction of Sodom and Gomorrah

Genesis xviii. 16-33; xix. 12-29.

VIII. The Sacrifice of IsAaC . . . .

22

Genesis xxii. I-I9.

IX. The Wooing of Rebekah

24

Genesis xxiv.

X. Esau and Jacob • • • • • • 30

Genesis xxv. 27-34; xxvii.-xxviii. 5 ; xxviii. 10xxix. 30 ; xxxii.-xxxiii. 17 .

XI. Joseph ANd his Brethren

Genesis xxxvii.; xxxix.-xlvi. 7; xlvi. 28-xlvii. 12.

XII. The Death of Jacob and Joseph . -

Genesis xlvii. 28-xlviii.; xlix. 33-1. 3; 1. 15-26.

XIII. Moses

Exodus i. $8 \cdot 14$; ii.-iv. 23 ; iv. 29-31. 
XIV. The Oppression of the IsRaelites

XV. The Ten Plagues

Exodus vi. 28-xii. 4 I.

XVI. The Passage of the Red Sea . . . IoI Exodus xiii. 17-xiv.

XVII. The Ten Commandments Exodus xix.-xx. 21.

XVIII. The Golden Calf

Exodus xxxii.

XIX. The Death of Moses . Deuteronomy xxxiv.

XX. Rahad and the Spies. Joshua ii.

XXI. The Siege of Jericho. Joshua vi.

XXII. Joshua at Gibeon . Joshua X. 1-15.

XXIII. The Death of Joshua Joshua xxiii.-xxiv. 3 I.

XXIV. Sisera ANd JaEL . Judges iv.

XXV. Gideon's Army Judges vii.

XXVI. ABImelech and Jotham Judges viii. 33-ix.

XXVII. Jephthah's Vow .

Judges xi. 30-40.

XXVIII. SAmSON

Judges xiii. 24-xvi.

XXIX. Ruth .

$$
\text { Ruth. }
$$

XXX. The Call of Samuel . 
SELECTION

PAGE

XXXI. The Ark of the Covenant . . . 159

1 Samuel iv. $1-18$.

XXXII. The Anointing of Saul . . . . . 161 I Samuel viii.-x. 9.

XXXIII. Jonathan AND his Armourbearer . . I Samuel xiv. 1-23.

XXXIV. Saul's Disobedience • . . . . 170 I Samuel xv.

XXXV. The Anointing of David . . . . 174 I Samuel xvi.

XXXVI. David and Goliath . . . . $\quad$. 176

I Samuel xvii.-xviii. 16.

XXXVII. David and Jonathan . . . . . 183 I Samuel xx.

XXXVIII. David and Saul . . . . . . $\quad$. 188

I Samuel xxiv.; xxvi.-xxvii. 4

XXXIX. The Witch of EN-Dor . . . . 193

1 Samuel xxviii. $3-25$; xxxi. 1-6.

Xl. David and Bath-Sheba . . . . 197 Ir Samuel xi.-xii. 24.

Xli. The Revolt of Absalom . . . . 202 II Samuel xviii.

XliI. The Judgment of Solomon . . . 206 I Kings iii. 5-28.

XliII. The Queen of Sheba . . . . . 208 I Kings X. I-13.

XliV. Rehoboam and Jeroboam . . . . 210 I Kings xi. 4-13; xi. 26-xii. 20.

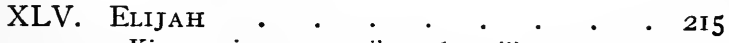

1 Kings xvi. 29-33; xvii. 1-16; xviii. 1-2; xviii. 17-xix.

XLVI. Naboth's Vineyard • • • • . 223 I Kings $x$ xi.

XlViI. The Death of Ahab . . . . . 226 I Kings xxii. 29-40. 
XLVIII. The Translation of Elijah • • • 227 II Kings ii.

XLIX. Elisha • • • • • • • 230 II Kings iv. 1-37.

L. NaAman, the Leper • • • • . 234 II Kings v.

LI. Jehu AND JeZEBeL • • • • • • 237 II Kings ix.

LII. The Death of Elisha • . . . 24I II Kings xiii. 14-20.

LIII. HEZEKIAH • • . • • • . 242 II Kings xviii. 1-17; xix. 1-19; xix. 35-xx.

LIV. Josiah's Renewal of the Covenant . 248 II Kings xxii.-xxiii. 5.

LV. The Capture of Jerusalem • • 252 II Kings xxiv. 8-xxv. I3.

LVI. ESTHER • • • • • • • 255 Esther.

LVII. Nebuchadnezzar's Dreams • • 274 Daniel ii. and iv.

LVIII. The Burning Fiery Furnace • • $\quad 284$ Daniel iii.

LIX. Belshazzar's Feast • • • • 287 Daniel v.

LX. The Den of Lions . • • . . 29I Daniel vi. 
Later in the Gospel of Matthew occurs this passage: "Thou shalt love the Lord thy God with all thy heart, and with all thy soul, and with all thy mind, This is the first and great commandment. And the second is like unto it, Thou shalt love thy neighbour as thyself. On these two commandments hang all the law and the prophets." In each quotation the final phrase is significant. It points to a distinction between parts of the Old Testament as familiar then as the distinction between the two Testaments is to-day. In its more extended form, "The Law, the Prophets, and the Other Writings (or, the Rest of the Books)," the phrase marks with reasonable accuracy the three major divisions in the formation of the Old Testament.

The processes of development within each division may be illustrated sufficiently by some comment upon the so-called "five books of Moses." Whoever reads the account of the death of Moses in the last chapter of Deuteronomy sees that the tradition which ascribes the authorship of the first five books of the Bible to Moses cannot be accepted literally in complete detail. In an earlier chapter in Deuteronomy, where Moses bids the Levites place the "book of the law" which he had written "in the side of the ark of the covenant," the reference is evidently not to the complete Pentateuch, or "five books of Moses," in the form now known to the English reader. Obviously the Pentateuch developed gradually, assuming final form only after many transitional stages. Hebrew literature followed a natural course. With primitive peoples records are transmitted rather by oral tradition 
than by written document. With progress from a nomadic state to more formal political organization comes the need of permanent laws and records. It has been claimed that the earliest written record in the Pentateuch was probably the "ten words of Moses," afterwards expanded into the Ten Commandments. At all events, as the legal and ceremonial aspects of Hebrew life and religion developed, there was a growing necessity for definite written documents. Broadly speaking, the process that went on was the constant transmission and revision, from age to age, of ever increasing literary material-history, law, poetry, religious ritual-until the original elements were moulded into a composite mass.

Higher Criticism has been busy with the task of resolving this composite into its original elements. Its general conclusions may be briefly indicated. The Pentateuch, in its final form, comes chiefly from the hands of priestly writers during and after the Hebrew exile in Babylon. Previously the various documents included in it had undergone several revisions. Four writers, or sets of writers, can be distinguished in the final composite. Of these the earliest are designated as the Jahvist (or Jehovist), who uses "Jahveh," and the Elohist, who uses "Elohim," to render " God." They date respectively from about 850 and 750 B.C. Their work, found chiefly in the Pentateuch and Joshua, was united by a later hand. The third writer, the Deuteronomist, dates from Josiah's promulgation of the original Deuteronomy in 62I B.C. Finally come the Priestly revisers, especially about the time 
of Ezra and Nehemiah, in the fifth century B.c. Various considerations of statement, style, and viewpoint aid the Biblical scholar in distinguishing the original elements thus merged in the final composite record.

After the student of literature has become somewhat familiar with the general processes of evolution of the text of the Bible, his inquiry is apt to turn toward the reasons for the inclusion of some and the rejection of other books in the formation of the accepted Bible. The word "Canon," meaning in the original Greek a "straight rod," is figuratively applied to those Scriptures which are accepted as genuinely of sacred authority, in distinction from the "apocryphal" books of uncertain authority. In 62I B.c. King Josiah took the "book of the law" found by the high priest, read it in solemn assembly to his people, and "made a covenant before the Lord, to walk after the Lord, and to keep his commandments and his testimonies and his statutes with all their heart and all their soul, to perform the words of this covenant that were written in this book. And all the people stood to the covenant." (2 Kings xxiii. 3.) The act marks the acceptance of certain written words as invested with peculiar sanctity.

During the period of the Babylonian exile, in the sixth century B.C., the priests developed more and more the authority of the Law. About the middle of the next century there returned from Babylon to Jerusalem with the second section of the Hebrew exiles, "a ready scribe in the law of Moses" named Ezra. He had "prepared his heart to seek the law 
of the Lord, and to do it, and to teach in Israel statutes and judgments." It has been suggested that he was "the final redactor of the Pentateuch, separating it from the historical work consisting of Joshua and the subsequent writings." He seems at least a central figure in the establishment of the "Law" as the final authority for the guidance of his race.

The second division, or "layer," in the Old Testament Canon-the "Prophets"-is linked with the name of Nehemiah. The second chapter of the second book of the Maccabees records that Nehemiah, "founding a library, gathered together the acts of the kings, and the prophets, and of David, and the epistles of the kings concerning the holy gifts." Nehemiah's collection included probably the historical books beginning with Joshua, most of the prophetic books, and some writings that did not establish themselves in the Canon. Later works, like the book of Jonah, were afterwards added, but in the second century B.c. the frequent use of the phrase, "The Law and the Prophets," seems to show that the second division of the Old Testament had been completed, and accepted side by side with the "Law."

The third division of the Old Testament includes the " Other Writings," or " The Rest of the Books." Their varying character and contents raise many details of controversy, but the general basis for their inclusion in the Canon is largely their connection with the previously accepted books. Thus the Psalms gain authority by association with David, and Proverbs with Solomon. Disputes as to the 
inclusion of such books as Esther and Ecclesiastes did, indeed, persist vigorously until about the end of the first century of the Christian era, and spasmodically even later. Furthermore, even the final establishment of the regular Hebrew Canon did not settle the matter for all sects. The Samaritans accepted only the Pentateuch, while the Alexandrian Jews used the Greek version of the Scriptures, the "Septuagint," which intermingled canonical and apocryphal books.

Josephus, the historian, in a memorable, but not wholly accurate passage (Contra Apion. i. 8), shows the attitude of many toward the Hebrew Canon in the latter part of the first century A.D.: "For we have not an innumerable multitude of books among us . . . but only twenty-two books, which contain the records of all the past times: which are justly believed to be divine." His added statement, that since the days of Artaxerxes-in whose reign Ezra returned from Babylon-" no one has been so bold as either to add anything to them, to take anything from them, or to make any change in them," is disproved by the history of his own century, but there were many to share the belief that the Hebrew Canon was closed. The modern reader notices the discrepancy between the thirty-nine books of the Old Testament, as they now stand, and the number given by Josephus. His list includes five books of Moses, thirteen of the Prophets, and four of "hymns to God and precepts for the conduct of human life." The number twenty-two corresponds with the number of letters in the Hebrew alphabet, and is usual with early Christian writers. In the 
Hebrew Bible, Samuel, Kings, and Chronicles counted as single, not double, books and there was other coupling of books which stand separate in the English Bible-as, for instance, Ezra and Nehemiah, Jeremiah and Lamentations. Questions of order and arrangement remained accordingly for later settlement, but, for present purposes, the history of the Hebrew Old Testament ends with the establishment of the Canon.

II. THE SEPTUAGINT AND THE VULGATE.

Two versions of the Bible in other languages have special significance in the history of the English Bible. The most important Greek version, the "Septuagint," owes its name to the tradition that it was the work of some seventy men. In its elaborated form the story went so far as to claim that the translation was made independently by seventytwo Jews, working in separate cells, and that their results when compared were found identical, and hence accepted as inspired. The marked inequalities of different parts of the work sufficiently disprove this legend and seem to support the belief that the version was the product of different times as well as of different hands. Probably begun about three hundred years before the Christian era, the Septuagint was the version used by the Alexandrian Jews and by the early Christians. From it were taken practically all the quotations from the Old Testament which occur in the Greek New Testament. In the first place, then, it ultimately, though indirectly, influenced the English translations of the 
Greek New Testament in form of literary expression. In the second place, it gave the modern order of arrangement of the Old Testament books. The Hebrew Canon, it will be recalled, had arranged its three layers in chronological order of development-the Law, the Prophets, the Other Writings. The Septuagint substituted a literary rearrangement - the historical books in proper sequence, then the poetic and wisdom books, and finally the prophets. In the third place, the Septuagint supplied to English translators the apocryphal books, which were not included in the Hebrew Canon but which possess at least marked literary importance.

Far more significant, however, in influence upon the English Bible was the great Latin version known as the "Vulgate." The name, derived from the Latin "vulgata" (supply " editio" or "versio"), signifies that it was the commonly known version. Down to the time of the Reformation, in fact, it was the Bible of the European Church. Toward the close of the fourth century A.D., the various Latin texts of the Scriptures had become so much corrupted that revision was imperative. For this important work the Pope selected the great scholar best known as Saint Jerome. Jerome's work consisted partly of revision of previous texts and partly of direct translation from the original Hebrew of the Old Testament. At first Jerome's Bible encountered violent opposition in some quarters, but eventually it established itself as the recognized version of the Western Church. In process of time errors of copyists and commentators corrupted Jerome's text so that there grew up various dis- 
cordant versions, and there was authoritative revision of the Vulgate text at the close of the sixteenth century.

The Vulgate vitally influenced the English Bible because it was the Bible of the Early English translators. The virile strength and rich beauty of Jerome's Latin animated and colored the literary style of Tyndale and his followers. Jerome's Latin was not classical, but that Low Latin which admitted more colloquial forms and greater flexibility of word-order and construction. Furthermore, Jerome's work was important in giving to the varying styles of earlier hands a common unity of expression. The Vulgate influenced directly the phrasing of specific passages even in the King James version, and in a larger sense stamped its impress infallibly on the general literary style of the English translators.

\section{ENGLISH VERSIONS OF THE BIBLE.}

Anglo-Saxon literature contains various versions of parts of the Bible, ranging from the free Paraphrase of Cædmon, the seventh-century monk who, according to the venerable Bede, "sang the creation of the world, the origin of man, and all the history of Genesis," together with many other things, to Bede's own translation of the Gospel according to St. John. It is characteristic of that devout spirit which linked naturally the sacred with the secular that Alfred the Great prefixed to his "Book of Laws," in somewhat altered form, the Ten Commandments of Moses. In general, the Anglo-Saxon 
Biblical versions now extant include the Psalter, the Gospels, the Pentateuch, and some of the Old Testament historical books. Doubtless there were other versions now lost, but though such works may have fostered the spirit of devotion, they can have had little tangible influence upon the letter of the text of the English Bible. After the Norman Conquest there were poetical paraphrases, like the Ormulum, written by the monk Orm, or Ormin, about the beginning of the thirteenth century, and finally some fourteenth-century versions of the Psalter, the earliest in English prose.

The first complete English translation of the Bible was primarily the work of John Wycliffe, the "Morning Star of the Reformation." Assisted by Nicholas of Hereford, who translated much of the Old Testament and of the Apocrypha, he rendered the Bible from the Latin of the Vulgate into English, about I382. Wycliffe died in I384, and a few years later John Purvey revised the work. Copies of the versions circulated in manuscript, despite the opposition of the Church and its prosecution of many who persisted in owning or reading the Bible in English.

From the scholarly standpoint the chief defect of Wycliffe's Bible is that it was translated not from the original Hebrew and Greek, but from the Latin of the imperfect Vulgate texts then current. From the popular standpoint its chief drawback was that it had to circulate in manuscript. Two mighty influences of the fifteenth century tended to remove these obstacles to the advance of the English Bible. The Renaissance, or revival of learning in Europe, 
spread the study of Greek among scholars; the discovery of the art of printing heralded the time when the Bible should become generally accessible to the people. The fall of Constantinople, in I453, turned the tide of Greek scholarship to Italy. Thence, scholars like Colet and Grocyn, who had studied in Italy, brought to England the new enthusiasm for learning. Oxford and Cambridge began to teach Greek, and finally, in 1516, Erasmus published the first edition of his Greek New Testament. Later editions were used by Luther and Tyndale. Fortunately, to Colet and Erasmus, scholarship was the means to a great end. For centuries theologians had been, to use Bacon's phrase, cymini sectores, "hairsplitters." Colet and Erasmus declared that the Bible could be readily understood by all and should not be reserved for a handful of theologians. "I totally dissent," wrote Erasmus, "from those who are unwilling that the Sacred Scriptures, translated into the vulgar tongue, should be read by private individuals, as if Christ had taught such subtle doctrines that they can with difficulty be understood by a very few theologians, or as if the strength of the Christian religion lay in men's ignorance of it."

The teachings of Colet and Erasmus found yet more powerful utterance in William Tyndale. Whether he studied directly under Colet at Oxford and under Erasmus at Cambridge is questionable, but at all events his years at both universities brought him close to the enthusiasm they had kindled. The desire of Erasmus that the husbandman might sing parts of the Scriptures at his 
plough is echoed in Tyndale's remark to a "learned man": "If God spare my life, ere many years I will cause a boy that driveth the plough shall know more of the Scripture than thou doest." Believing that "it was impossible to establish the lay people in any truth except the Scripture were plainly laid before their eyes in their mother tongue, that they might see the process, order and meaning of the text," Tyndale set himself to translate the Bible into English. Unable to accomplish his task either in the country or in London, where he vainly sought the aid of the Bishop of London, he left England forever. Even on the Continent danger threatened. Enemies interrupted his attempt to print his work in Cologne, but in the Lutheran city of Worms he completed both the annotated quarto edition of the New Testament begun at Cologne and an octavo edition without marginal notes-the first English versions translated from the original Greek.

Despite warnings to Henry VIII. of the impending "infection and danger," despite determined efforts to destroy or to exclude Tyndale's translation, copies of his New Testament arrived in England early in . I526, and circulated rapidly. Attacks upon the translation as heretical and confiscation and burning of copies of the work were alike ineffective in stilling the tide of awakening popular interest. Some four years later Tyndale published a translation from the Hebrew of the Pentateuch, and in 1534 a revision of his New Testament. When Tyndale's Testament was burned in England he wrote: "In burning the New Testament, they did none other thing than I looked for; no 
more shall they do if they burn me also, if it be God's will it shall so be." The words were prophetic. Betrayed in Antwerp, Tyndale met death at the stake in I536. In his Book of Martyrs, Foxe rightly called him " an apostle of England."

Tyndale was the father of the modern English Bible. He fixed essentially its literary style. Study of his vocabulary and phrase emphasizes the resemblances rather than the differences between his text and later versions. Clearness, simplicity, vigor, vividness, dignity-these were the qualities which Tyndale impressed upon the English Bible. To other revisers we owe countless and important changes in detail; to Tyndale we owe the very character of the noblest English prose. Scholarly research has shown the remarkable influence of Tyndale upon the Authorised Version, even in the reproduction of faults and inconsistencies in his rendering. Partisans of Wycliffe have sometimes sought to transfer to him much of the credit due to Tyndale, but few who study the biography of Tyndale will be disposed to question the sincerity of his statement that he had "no man to counterfeit [imitate], neither was holpen with English of any that had interpreted the same or such like thing in the Scripture beforetime."

Tyndale never translated the entire Bible. The first complete translation into English by a single hand was published by Miles Coverdale, in I 535 . In the decade since Tyndale's New Testament had appeared, Henry VIII. had been proclaimed supreme head of the Church of England, and had broken with the Pope, who had refused to sanction his 
marriage to Anne Boleyn. 'Tyndale's work had gone forth without even bearing his name; Coverdale was able to issue his work under the patronage of Thomas Cromwell, and with a dedication to the king. Coverdale's translation was not direct, but was based on "sundry translations, not only in Latin, but also of the Dutch [German] interpreters," and on Tyndale. His own modest disclaimers show that he spoke not with authority, but as one of the scribes. His chief services were in maintaining Tyndale's simplicity of diction, while imparting greater finish and rhythm of phrase, and in completing the Old Testament translation.

In I 537 appeared Matthew's Bible. Possibly the name of Thomas Matthew, which stands on the title-page as that of the translator, was only assumed by John Rogers, who edited the work. In all probability Matthew's Bible contains for the first time a translation by Tyndale of the books from Joshua through Chronicles, which he might readily have intrusted to Rogers during his association with him in Antwerp. In general, Matthew's Bible followed the translation of Tyndale, supplying the missing parts from Coverdale's complete version. ${ }^{1}$

Tyndale's translation had been vigorously assailed by the king; Coverdale's first edition, though rot directly sanctioned by the king, was not suppressed, and the editions of I 537 were "set forth with the king's most gracious license;" Matthew's Bible, though it contained Tyndale's condemned work, was " allowed by his [the king's] authority to be bought

${ }^{1}$ Of minor importance is Taverner's Bible, printed in London in 1539, based chiefly on Matthew's. 
and read within this realm." Still more authoritative sanction by the government was accorded to the "Great Bible" of I539. Thomas Cromwell, who had been instrumental in securing the king's license for the English Bible, sent Miles Coverdale to Paris to prepare a new version based on Matthew's. The work was interrupted by the power of the Inquisition, but Coverdale and Grafton, his printer, escaped to London with workmen, presses, and most of their printed sheets, and completed the work. In I540 a second edition appeared, with a preface by Archbishop Cranmer, and though the "Great Bible" was due mainly to Coverdale's labor and Cromwell's zealous support, the work is frequently known as "Cranmer's Bible." When the king issued a favorable declaration "to be read by all curates upon the publishing of the Bible in English," when six Bibles were set up in St. Paul's Church to be read by the people, and when six editions of the Great Bible were printed in 1540 and I54I, it seemed that the English Bible had become at last an open book.

The current so favorable to the English Bible soon turned. In I 543 Parliament passed a stringent act restricting the reading of the Scriptures, proscribed Tyndale's work, and required the excision of notes in other copies of the Bible. Three years later Coverdale's New Testament came also under the ban. The death of Henry and the accession of Edward VI., in I547, checked the reaction. In the six and a half years of Edward's brief reign there appeared thirteen editions of the entire Bible and thirty-five of the New Testament. The young 
king not merely removed Henry's restrictions upon the use of the Bible, but required that copies should be set up for reading in the churches.

In the reign of Mary the pendulum swung back again to the side of reaction. Rogers and Cranmer suffered death, Coverdale and many other English Protestants became refugees on the Continent, and the English press was shut against the Bible. Geneva, the home of Calvin, was a natural refuge for the English Calvinists. From that little band of exiles came a new translation of the Bible of wide-reaching significance. The Genevan Testament, probably the work of Whittingham, who had married Calvin's sister, was published in 1557. An interesting detail connected with the work is that it gave to English readers for the first time the modern system of short verses in the arrangement of the text. With the accession of Elizabeth, in I558, most of the Protestant exiles returned to England, but two or three remained with Whittingham to complete the Biblical translation. The Genevan Bible ${ }^{1}$ was printed in 1560 . Everything seemed to conspire in favor of its success. The work had been accomplished under circumstances in reality favorable. The very exile of the translators deepened their solemn devotion to their task, and in Geneva their labors were uninterrupted by political turmoil at home. The work was brought forth after Elizabeth had succeeded to the throne. It was printed in Roman letter, with chapters divided

1 Popularly, it is known as the "Breeches Bible," on account of the rendering "made themselves breeches," in the third chapter of Genesis. 
into verses, and in quarto form instead of in the unwieldy folios that had preceded it. The marginal comments were clear and to the point. The dominant note of the translation was faithful accuracy to the original texts. Although it did not supplant the Great Bible in English ecclesiastical use, the Genevan Bible was so popular that some seventy editions of all descriptions were issued during Elizabeth's reign. For the larger part of a century it was the household Bible of the English people.

The popularity of the Genevan Bible soon brought to light the imperfections of the Great Bible, which was still in Church use since the Genevan Bible was colored by traces of Calvinistic theology in its notes. Archbishop Parker determined with the aid of various scholars to make a satisfactory revision. Since many of his helpers were bishops, the work which finally appeared in I568 was known as the Bishops' Bible. As different books were assigned to different men, the translation was not uniform, and though it obtained the sanction of the Church, it deservedly failed to supplant the Genevan Bible in general use.

In I 582 was published at Rheims a translation of the New Testament made by Gregory Martin and other Oxford scholars, of the Roman Catholic faith. William Allen, founder of the Romish Seminary at Douai, which was transferred, in 1578 , for a time to Rheims, sought to reëstablish the power of the Church of Rome in England. The translation which he doubtless suggested was, accordingly, to be based on the Vulgate, the accepted text of the Roman Catholic Church. The appearance of the 
Old Testament translation, at Douai, was delayed until I609-10. These works are usually known as the Rhemish New Testament and the Douai Bible. In versions based on the Vulgate it was natural that Latin diction should strongly color the translation. Many renderings of the Rhemish New Testament were retained in the Authorised Version, with marked gain in richness and variety of phrase. Thus the work of scholars on the Continent directly aided the next translation in England, the King James or Authorised Version.

IV. THE KING JAMES OR AUTHORISED VERSION.

At the accession of James I., the two English versions of the Bible in widest use were the Bishops' Bible, sanctioned for ecclesiastical use, and the Genevan Bible, the common version of the people. This unfortunate conflict of authority was soon to be settled. In January, I604, there was held the Hampton Court Conference, convoked by the new king to settle differences between the Puritans and the Church of England. Among the minor proceedings one developed ultimately into paramount importance. Dr. Reynolds, President of Corpus Christi College, Oxford, a Puritan leader, " moved his Majesty that there might be a new translation of the Bible, because those which were allowed in the reign of King Henry VIII. and Edward VI. were corrupt, and not answerable to the truth of the original." Although the Conference adjourned without further steps in this matter, the king evidently approved the suggestion. On July 22 he wrote to the Bishop of London that he had "ap- 
pointed certain learned men, to the number of four and fifty, for the translating of the Bible," and instructed him to enlist the aid of learned scholars, and to provide preferment in the Church for the translators. Serious work on the revision hardly began before I607. The lists of translators now extant give but forty-seven names instead of the fifty-four of the king's letter, and doubtless there were various modifications of the original plans. The work was finally executed by six companies, two at Westminster, two at Cambridge, and two at Oxford. They divided among them the books not merely of the Old and New Testaments but of the Apocrypha. The rules of revision provided that the Bishops' Bible " be followed, and as little altered as the truth of the original will permit," but "these translations to be used when they agree better with the text than the Bishops' Bible: Tindale's, Matthew's, Coverdale's, Whitchurch's, ${ }^{1}$ Geneva." No marginal notes were to be affixed save for explanation of difficult Hebrew and Greek words, but cross-references from one part of the Bible to another were provided. In each company the different scholars were at first to work independently, then to compare notes, and then to submit their joint results to the other companies. Knotty points were to be adjusted in a general meeting " of the chief persons of each company." The final revision occupied nine months, and was followed by the publication of the work in I6II.

It is natural to ask what were the chief reasons for the supremacy of the Authorised Version. It ' Whitchurch was the printer of the Great Bible. 
should, indeed, be remembered that it did not win immediately unanimous favor. Puritans missed the Calvinistic tinge of the notes and commentary of the Genevan Bible; others objected because they thought that parts of it were unfairly rendered. Within half a century, however, the Authorised Version grew steadily into general acceptance. Three main characteristics, at least, account for the enduring vitality of the Authorised Version-depth of scholarship, breadth of spirit, and beauty of diction. In the first place, no previous translation of the Bible had been made with equal labor or scholarly research. The Address to the Reader contrasts the slowness of the work with the "posting haste" of the Septuagint, and the careful revision with the uncorrected work of Jerome. Previous translations and commentaries of English and Continental scholars and the Aramaic and Syriac versions were used in connection with the original Hebrew and Greek texts. "Neither did we disdain," wrote the translators, "to revise that which we had done, and to bring back to the anvil that which we had hammered: but having and using as great helps as were needful, and fearing no reproach for slowness, nor coveting praise for expedition, we have at the length, through the good hand of the Lord upon us, brought the work to that pass that you see."

In the second place, the Authorised Version was executed in a broad and sympathetic spirit. The provision for the rigid restriction of marginal notes tended to substitute for the Calvinistic tone of the Genevan Bible and for the sectarian bias 
elsewhere discoverable a spirit of wider tolerance. Testimony seems to prove that King James objected to the inclusion of marginal notes because some annotations in the Genevan Bible showed scant respect for the doctrine of the divine right of kings, but in any case the omission of matter that might excite controversy was a decided gain. It is characteristic of the broad spirit in which the revisers worked that, instead of holding to the letter of their instructions, they availed themselves of the best in works like the Roman Catholic Rhemish Version. Puritan, Churchman, and independent scholar worked in common accord, and struck a happy mean betwcen what they termed "the scrupulosity of the Puritans" and "the obscurity" of some scholars. Conceived in such spirit, the Authorised Version became the Bible not of a particular sect, but of the English people.

In the third place, the Authorised Version set the highest standard in simplicity and beauty of diction. Through the process of years the English Version of the Bible had grown steadily in wealth of vocabulary and flexibility of phrase. Objection has been made to the frequent practice of rendering the same word in various ways, but the loss in strict accuracy is, from the literary standpoint, more than offset by the gain in richness and variety of expression. Never probably was the English vocabulary better fitted for the translators' purpose than when it was surcharged with the rich, virile, and concrete words and imagery inherited from the Elizabethan period. Age cannot wither it, nor custom stale its infinite variety. Subsequent additions have enormously 
increased the vocabulary of scientific, philosophical, and abstract terms, but these would have clogged rather than enriched the Biblical style. The Elizabethans and their immediate successors had to a marked degree the faculty of choosing the right word for the right place. The phrasing of the Authorised Version has that inevitableness which carries conviction. The matchless simplicity of the Biblical style has been a powerful factor in maintaining its influence. Not even Bunyan, who felt so strongly its potency, makes such an immediate and direct appeal.

Striking testimony as to "the uncommon beauty and marvellous English" of the Authorised Version is found in the words of the Romanist Father Faber:" "It lives on the ear like a music that can never be forgotten, like the sound of church bells, which the convert scarcely knows how he can forego. Its felicities seem often to be almost things rather than words. It is part of the national mind, and the anchor of the national seriousness.

The memory of the dead passes into it. The potent traditions of childhood are stereotyped in its verses. It is the representative of a man's best moments; all that there has been about him of soft, and gentle, and pure, and penitent, and good speaks to him for ever out of his English Bible."

\section{THE REVISED VERSION.}

For some two centuries and a half the Authorised Version held the field with little challenge to its

"Quoted in J. Paterson Smyth's "How we got Our Bible," pp. IIo-III. 
supremacy. When the Book of Common Prayer was issued in revised form in 1662, the Psalter of the Great Bible was still retained, but with few exceptions the text of the I6I I translation was adopted elsewhere, as in the Gospels and Epistles. In the nineteenth century, however, the multiplication of ancient manuscripts hitherto unknown, the advance in textual scholarship, and the inevitable changes in the English vocabulary began to present themselves increasingly as reasons for a revision of the Authorised Version. These tendencies culminated in February, I870, in the action taken by the Convocation of Canterbury: "That a Committee of both Houses be appointed, with power to confer with any Committee that may be appointed by the Convocation of the Northern Province, to report upon the desirableness of a revision of the Authorised Version of the Old and New Testaments, whether by marginal notes or otherwise, in all those passages where plain and clear errors, whether in the Hebrew or Greek text originally adopted by the translators, or in the translation made from the same, shall, on due investigation, be found to exist." Though the Northern Province declined to cooperate, it was determined to proceed with the work of revision, dividing it between an Old Testament Company and a New Testament Company. A distinguished array of divines and scholars undertook the work, both companies holding their first meetings in June, I870. Not long afterwards steps were taken to enlist the aid of American scholars, and two American companies began their labors in October, I872. The revision of the New Testa- 
ment was completed in r880, and the entire Revised Version of the Bible appeared in May, I885.

The very name, Revised Version, shows that the intent was to make not a new translation of the Bible, but a revision of the accepted translation. Of the general principles adopted by the revisers it is significant that the first two are these: "I. To introduce as few alterations as possible into the text of the Authorised Version consistently with faithfulness. 2. To limit, as far as possible, the expression of such alterations to the language of the Authorised and earlier English Versions." Whether the Revised Version will ultimately supplant the Authorised Version is a question to be determined in the future. The superior scholarship and textual accuracy of the revision is conceded almost without question. From the literary standpoint, the greatest gain seems to be in the emphasis upon literary construction, as in the grouping of many verses into a single paragraph with reference to the thought, and in recognition of the distinction between prose and verse in Hebrew literature. Notwithstanding the many merits of the Revised Version, the fact remains that from the literary viewpoint it must still concede the pride of place to the Authorised Version. It is the Authorised Version which for almost three centuries has been an integral part of English literature, the source of endless literary reference, the crowning achievement of English prose. Gain in precision of rendering in the Revised Version has not outweighed the sacrifice of somewhat of the breadth and elemental vigor of the King James 
Version. Whether, as has been suggested, the spirit of scholarly revisers in these latter days sinks inevitably below that of men who stood close to martyrs whose blood had consecrated the pages of the Bible translation, or whether modern imitation lacks Elizabethan virility of diction are questions not to be settled by mathematical proof. But, at least for our day and generation, the Bible of English Literature is still the Authorised Version of I6II. 

$$
\text { - }
$$ 


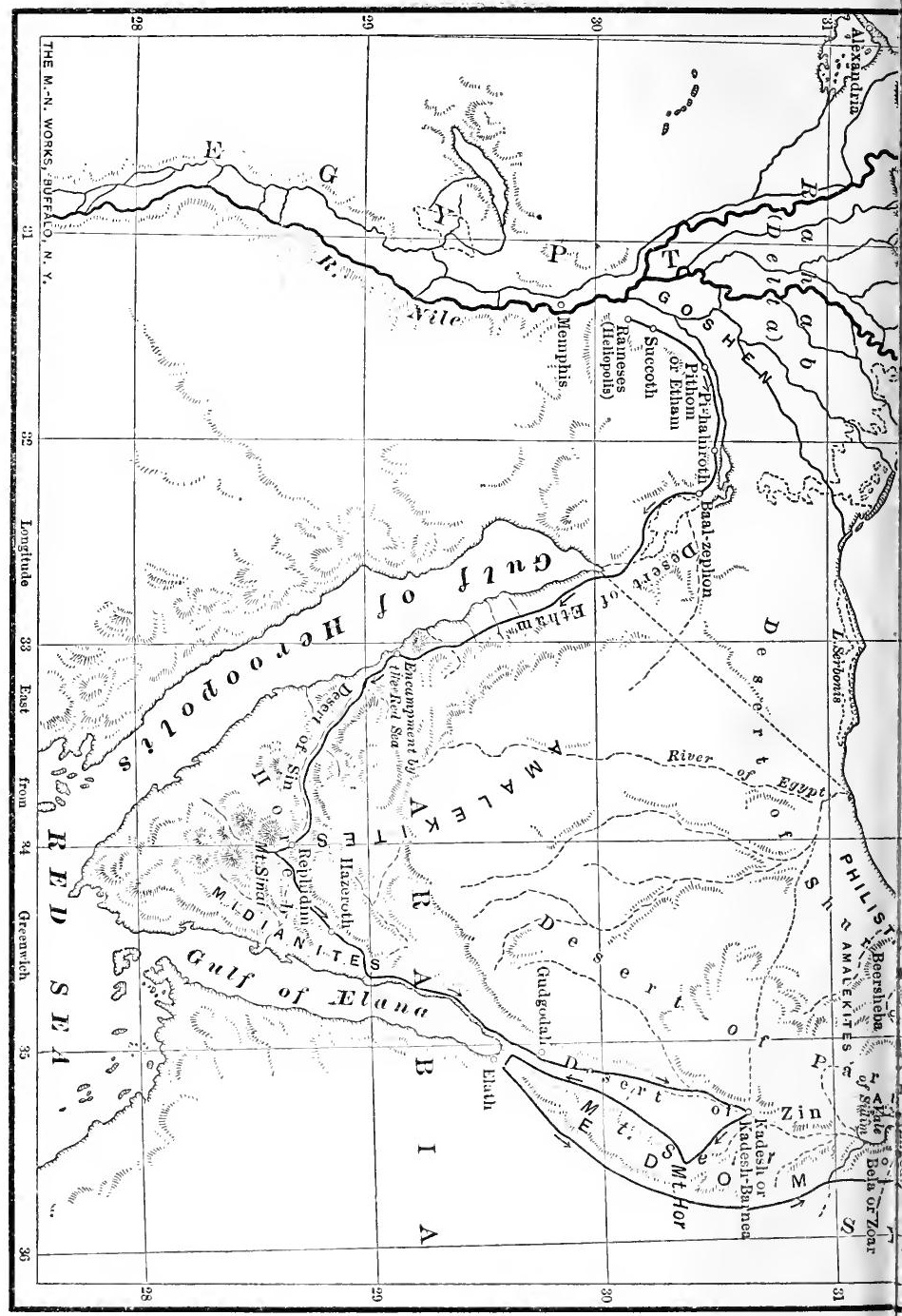




\section{OLD TESTAMENT NARRATIVES}

\section{I.}

Tbe creation.

Genesis i.-ii. 3.

In the beginning God created the heaven and the earth. And the earth was without form, and void; and darkness was upon the face of the deep. And the Spirit of God moved upon the face of the waters. And God said, Let there be light: and there was light. And God saw the light, that it was good: and God divided the light from the darkness. And God called the light Day, and the darkness he called Night. And the evening and the morning were the first day.

And God said, Let there be a firmament in the midst of the waters, and let it divide the waters from the waters. And God made the firmament, and divided the waters which were under the firmament from the waters which were above the firmament: and it was so. And God called the firmament Heaven. And the evening and the morning were the second day.

And God said, Let the waters under the heaven be gathered together unto one place, and let the dry land appear: and it was so. And God called the 
dry land Earth; and the gathering together of the waters called he Seas: and God saw that it was good. And God said, Let the earth bring forth grass, the herb yielding seed, and the fruit tree yielding fruit after his kind, whose seed is in itself, upon the earth: and it was so. And the earth brought forth grass, and herb yielding seed after his kind, and the tree yielding fruit, whose seed was in itself, after his kind: and God saw that it was good. And the evening and the morning were the third day.

And God said, Let there be lights in the firmament of the heaven to divide the day from the night; and let them be for signs, and for seasons, and for days, and years: and let them be for lights in the firmament of the heaven to give light upon the earth: and it was so. And God made two great lights; the greater light to rule the day, and the lesser light to rule the night: he made the stars also. And God set them in the firmament of the heaven to give light upon the earth, and to rule over the day and over the night, and to divide the light from the darkness: and God saw that it was good. And the evening and the morning were the fourth day.

And God said, Let the waters bring forth abundantly the moving creature that hath life, and fowl that may fly above the earth in the open firmament of heaven. And God created great whales, and every living creature that moveth, which the waters brought forth abundantly, after their kind, and every winged fowl after his kind: and God saw that it was good. And God blessed them, saying, 
Be fruitful, and multiply, and fill the waters in the seas, and let fowl multiply in the earth. And the evening and the morning were the fifth day.

And God said, Let the earth bring forth the living creature after his kind, cattle, and creeping thing, and beast of the earth after his kind: and it was so. And God made the beast of the earth after his kind, and cattle after their kind, and every thing that creepeth upon the earth after his kind: and God saw that it was good. And God said, Let us make man in our image, after our likeness: and let them have dominion over the fish of the sea, and over the fowl of the air, and over the cattle, and over all the earth, and over every creeping thing that creepeth upon the earth. So God created man in his own image, in the image of God created he him; male and female created he them. And God blessed them, and God said unto them, Be fruitful, and multiply, and replenish the earth, and subdue it: and have dominion over the fish of the sea, and over the fowl of the air, and over every living thing that moveth upon the earth. And God said, Behold, I have given you every herb bearing seed, which is upon the face of all the earth, and every tree, in the which is the fruit of a tree yielding seed; to you it shall be for meat. And to every beast of the earth, and to every fowl of the air, and to every thing that creepeth upon the earth, wherein there is life, I have given every green herb for meat: and it was so. And God saw every thing that he had made, and, behold, it was very good. And the evening and the morning were the sixth day. 
Thus the heavens and the earth were finished, and all the host of them. And on the seventh day God ended his work which he had made; and he rested on the seventh day from all his work which he had made. And God blessed the seventh day, and sanctified it: because that in it he had rested from all his work which God created and made.

\section{II. \\ The Garden of Eoen.}

Genesis ii. 4-iii.

THEse are the generations of the heavens and of the earth when they were created, in the day that the Lord God made the earth and the heavens, and every plant of the field before it was in the earth, and every herb of the field before it grew: for the Lord God had not caused it to rain upon the earth, and there was not a man to till the ground. But there went up a mist from the earth, and watered the whole face of the ground. And the Lord God formed man of the dust of the ground, and breathed into his nostrils the breath of life; and man became a living soul.

And the Lord God planted a garden eastward in Eden; and there he put the man whom he had formed. And out of the ground made the L.ord God to grow every tree that is pleasant to the sight, and good for food; the tree of life also in the midst of the garden, and the tree of knowledge of good and evil. And a river went out of Eden to water 
the garden; and from thence it was parted, and became into four heads. The name of the first is Pison: that is it which compasseth the whole land of Havilah, where there is gold; and the gold of that land is good: there is bdellium and the onyx stone. And the name of the second river is Gihon: the same is it that compasseth the whole land of Ethiopia. And the name of the third river is Hiddekel : that is it which goeth toward the east of Assyria. And the fourth river is Euphrates.

And the Lord God took the man, and put him into the garden of Eden to dress it and to keep it. And the Lord God commanded the man, saying, Of every tree of the garden thou mayest freely eat: but of the tree of the knowledge of good and evil, thou shalt not eat of it: for in the day that thou eatest thereof thou shalt surely die.

And the Lord God said, It is not good that the man should be alone; I will make him an help meet for him. And out of the ground the Lord God formed every beast of the field, and every fowl of the air; and brought them unto Adam to see what he would call them: and whatsoever Adam called every living creature, that was the name thereof. And Adam gave names to all cattle, and to the fowl of the air, and to every beast of the field; but for Adam there was not found an help meet for him. And the Lord God caused a deep sleep to fall upon Adam, and he slept: and he took one of his ribs, and closed up the flesh instead thereof; and the rib, which the Lord God had taken from man, made he a woman, and brought her unto the man. And Adam said, This is now bone of my bones, and flesh 
of my flesh: she shall be called Woman, because she was taken out of Man. Therefore shall a man leave his father and his mother, and shall cleave unto his wife: and they shall be one flesh. And they were both naked, the man and his wife, and were not ashamed.

Now the serpent was more subtil than any beast of the field which the Lord God had made. And he said unto the woman, Yea, hath God said, Ye shall not eat of every tree of the garden? And the woman said unto the serpent, We may eat of the fruit of the trees of the garden: but of the fruit of the tree which is in the midst of the garden, Gou hath said, Ye shall not eat of it, neither shall ye touch it, lest ye die. And the serpent said unto the woman, Ye shall not surely die: for God doth know that in the day ye eat thereof, then your eyes shall be opened, and ye shall be as gods, knowing good and evil. And when the woman saw that the tree was good for food, and that it was pleasant to the eyes, and a tree to be desired to make one wise, she took of the fruit thereof, and did eat, and gave also unto her husband with her; and he did eat. And the eyes of them both were opened, and they knew that they were naked; and they sewed fig leaves together, and made themselves aprons.

And they heard the voice of the Lord God walking in the garden in the cool of the day: and Adam and his wife hid themselves from the presence of the Lord God amongst the trees of the garden. And the Lord God called unto Adam, and said unto him, Where art thou? And he said, I heard thy voice in the garden, and I was afraid, because 
I was naked; and I hid myself. And he said, Who told thee that thou wast naked? Hast thou eaten of the tree, whereof I commanded thee that thou shouldest not eat? And the man said, The woman whom thou gavest to be with me, she gave me of the tree, and I did eat. And the Lord God said unto the woman, What is this that thou hast done? And the woman said, The serpent beguiled me, and I did eat.

And the Lord God said unto the serpent, Because thou hast done this, thou art cursed above all cattle, and above every beast of the field; upon thy belly shalt thou go, and dust shalt thou eat all the days of thy life: and I will put enmity between thee and the woman, and between thy seed and her seed; it shall bruise thy head, and thou shalt bruise his heel. Unto the woman he said, I will greatly multiply thy sorrow and thy conception; in sorrow thou shalt bring forth children; and thy desire shall be to thy husband, and he shall rule over thee. And unto Adam he said, Because thou hast hearkened unto the voice of thy wife, and hast eaten of the tree, of which I commanded thee, saying, Thou shalt not eat of it: cursed is the ground for thy sake; in sorrow shalt thou eat of it all the days of thy life; thorns also and thistles shall it bring forth to thee; and thou shalt eat the herb of the field; in the sweat of thy face shalt thou eat bread, till thou return unto the ground; for out of it wast thou taken: for dust thou art, and unto dust shalt thou return. And Adam called his wife's name Eve [i.e. "Living"] ; because she was the mother of all living. Unto Adam also and to his wife did 
the Lord God make coats of skins, and clothed them.

And the Lord God said, Behold, the man is become as one of us, to know good and evil: and now, lest he put forth his hand, and take also of the tree of life, and eat, and live for ever: therefore the Lord God sent him forth from the garden of Eden, to till the ground from whence he was taken. So he drove out the man; and he placed at the east of the garden of Eden Cherubims, and a flaming sword which turned every way, to keep the way of the tree of life.

\section{III.}

\section{Caín and $\mathfrak{A}$ bel.}

Genesis iv. I-I5.

And Adam knew Eve his wife; and she conceived, and bare Cain, and said, I have gotten a man from the Lord. And she again bare his brother Abel. And Abel was a keeper of sheep, but Cain was a tiller of the ground. And in process of time it came to pass, that Cain brought of the fruit of the ground an offering unto the Lord. And Abel, he also brought of the firstlings of his flock and of the, fat thereof. And the Lord had respect unto Abel and to his offering: but unto Cain and to his offering he had not respect. And Cain was very wroth, and his countenance fell. And the Lord said unto Cain, Why art thou wroth? and why is thy countenance fallen? If thou doest well, shalt thou not be 
accepted? and if thou doest not well, sin lieth at the door. And unto thee shall be his desire, and thou shalt rule over him.

And Cain talked with Abel his brother: and it came to pass, when they were in the field, that Cain rose up against Abel his brother, and slew him. And the Lord said unto Cain, Where is Abel thy brother? And he said, I know not: am I my brother's keeper? And he said, What hast thou done? the voice of thy brother's blood crieth unto me from the ground. And now art thou cursed from the earth, which hath opened her mouth to receive thy brother's blood from thy hand; when thou tillest the ground, it shall not henceforth yield unto thee her strength; a fugitive and a vagabond shalt thou be in the earth. And Cain said unto the Lord, My punishment is greater than I can bear. Behold, thou hast driven me out this day from the face of the earth; and from thy face shall I be hid; and $I$ shall be a fugitive and a vagabond in the earth; and it shall come to pass, that every one that findeth me shall slay me. And the Lord said unto him, Therefore whosoever slayeth Cain, vengeance shall be taken on him sevenfold. And the Lord set a mark upon Cain, lest any finding him should kill him.

\section{IV.}

\section{Tbe Jflood.}

Genesis vi. 5-ix. I7.

AND God saw that the wickedness of man was great in the earth, and that every imagination of 
the thoughts of his heart was only evil continually. And it repented the Lord that he had made man on the earth, and it grieved him at his heart. And the Lord said, I will destroy man whom I have created from the face of the earth; both man, and beast, and the creeping thing, and the fowls of the air; for it repenteth me that I have made them. But Noah found grace in the eyes of the Lord.

These are the generations of Noah: Noah was a just man and perfect in his generations, and Noah walked with God. And Noah begat three sons, Shem, Ham, and Japheth. The earth also was corrupt before God, and the earth was filled with violence. And God looked upon the earth, and, behold, it was corrupt; for all flesh had corrupted his way upon the earth.

And God said unto Noah, The end of all flesh is come before me; for the earth is filled with violence through them; and, behold, I will destroy them with the earth. Make thee an ark of gopher wood; rooms shalt thou make in the ark, and shalt pitch it within and without with pitch. And this is the fashion which thou shalt make it of: the length of the ark shall be three hundred cubits, the breadth of it fifty cubits, and the height of it thirty cubits. A window shalt thou make to the ark, and in a cubit shalt thou finish it above; and the door of the ark shalt thou set in the side thereof; with lower, second, and third stories shalt thou make it. And, behold, I, even I, do bring a flood of waters upon the earth, to destroy all flesh, wherein is the breath of life, from under heaven; and every thing that is in the earth shall die. But with thee will I estab- 
lish my covenant; and thou shalt come into the ark, thou, and thy sons, and thy wife, and thy sons' wives with thee. And of every living thing of all flesh, two of every sort shalt thou bring into the ark, to keep them alive with thee; they shall be male and female. Of fowls after their kind, and of cattle after their kind, of every creeping thing of the earth after his kind, two of every sort shall come unto thee, to keep them alive. And take thou unto thee of all food that is eaten, and thou shalt gather it to thee; and it shall be for food for thee, and for them. Thus did Noah; according to all that God commanded him, so did he.

And the Lord said unto Noah, Come thou and all thy house into the ark; for thee have I seen righteous before me in this generation. Of every clean beast thou shalt take to thee by sevens, the male and his female: and of beasts that are not clean by two, the male and his female. Of fowls also of the air by sevens, the male and the female; to keep seed alive upon the face of all the earth. For yet seven days, and I will cause it to rain upon the earth forty days and forty nights; and every living substance that I have made will I destroy from off the face of the earth. And Noah did according unto all that the Lord commanded him. And Noah was six hundred years old when the flood of waters was upon the earth.

And Noah went in, and his sons, and his wife, and his sons' wives with him, into the ark, because of the waters of the flood. Of clean beasts, and of beasts that are not clean, and of fowls, and of every thing that creepeth upon the earth, there went in 
two and two unto Noah into the ark, the male and the female, as God had commanded Noah. And it came to pass after seven lays, that the waters of the flood were upon the earth. In the six hundredth year of Noah's life, in the second month, the seventeenth day of the month, the same day were all the fountains of the great deep broken up, and the windows of heaven were opened. And the rain was upon the earth forty days and forty nights. In the selfsame day entered Noah, and Shem, and Ham, and Japheth, the sons of Noah, and Noah's wife, and the three wives of his sons with them, into the ark; they, and every beast after his kind, and all the cattle after their kind, and every creeping thing that creepeth upon the earth after his kind, and every fowl after his kind, every bird of every sort. And they went in unto Noah into the ark, two and two of all flesh, wherein is the breath of life. And they that went in, went in male and female of all flesh, as God had commanded him: and the Lord shut him in.

And the flood was forty days upon the earth; and the waters increased, and bare up the ark, and it was lift up above the earth. And the waters prevailed, and were increased greatly upon the earth; and the ark went upon the face of the waters. And the waters prevailed exceedingly upon the earth; and all the high hills, that were under the whole heaven, were covered. Fifteen cubits upward did the waters prevail; and the mountains were covered. And all flesh died that moved upon the earth, both of fowl, and of cattle, and of beast, and of every creeping thing that creepeth upon the earth, 
and every man: all in whose nostrils was the breath of life, of all that was in the dry land, died. And every living substance was destroyed which was upon the face of the ground, both man, and cattle, and the creeping things, and the fowl of the heaven; and they were destroyed from the earth: and Noah only remained alive, and they that were with him in the ark. And the waters prevailed upon the earth an hundred and fifty days. And God remembered Noah, and every living thing, and all the cattle that was with him in the ark: and God made a wind to pass over the earth, and the waters asswaged; the fountains also of the deep and the windows of heaven were stopped, and the rain from heaven was restrained; and the waters returned from off the earth continually: and after the end of the hundred and fifty days the waters were abated. And the ark rested in the seventh month, on the seventeenth day of the month, upon the mountains of Ararat. And the waters decreased continually until the tenth month: in the tenth month, on the first day of the month, were the tops of the mountains seen.

And it came to pass at the end of forty days, that Noah opened the window of the ark which he had made: and he sent forth a raven, which went forth to and fro, until the waters were dried up from off the earth. Also he sent forth a dove from him, to see if the waters were abated from off the face of the ground; but the dove found no rest for the sole of her foot, and she returned unto him into the ark, for the waters were on the face of the whole earth: then he put forth his hand, and took her, 
and pulled her in unto him into the ark. And he stayed yet other seven days; and again he sent forth the dove out of the ark; and the dove came in to him in the evening; and, lo, in her mouth was an olive leaf pluckt off: so Noah knew that the waters were abated from off the earth. And he stayed yet other seven days; and sent forth the dove; which returned not again unto him any more.

And it came to pass in the six hundredth and first year, in the first month, the first day of the month, the waters were dried up from off the earth: and Noah removed the covering of the ark, and looked, and, behold, the face of the ground was dry. And in the second month, on the seven and twentieth day of the month, was the earth dried. And God spake unto Noah, saying, Go forth of the ark, thou, and thy wife, and thy sons, and thy sons' wives with thee. Bring forth with thee every living thing that is with thee, of all flesh, both of fowl, and of cattle, and of every creeping thing that creepeth upon the earth; that they may breed abundantly in the earth, and be fruitful, and multiply upon the earth. And Noah went forth, and his sons, and his wife, and his sons' wives with him: every beast, every creeping thing, and every fowl, and whatsoever creepeth upon the earth, after their kinds, went forth out of the ark.

And Noah builded an altar unto the Lord; and took of every clean beast, and of every clean fowl, and offered burnt offerings on the altar. And the Lord smelled a sweet savour; and the Lord said in his heart, I will not again curse the ground any more for man's sake; for the imagination of man's 
heart is evil from his youth; neither will I again smite any more every thing living, as I have done. While the earth remaineth, seedtime and harvest, and cold and heat, and summer and winter, and day and night shall not cease.

And God blessed Noah and his sons, and said unto them, Be fruitful, and multiply, and replenish the earth. And the fear of you and the dread of you shall be upon every beast of the earth, and upon every fowl of the air, upon all that moveth upon the earth, and upon all the fishes of the sea; into your hand are they delivered. Every moving thing that liveth shall be meat for you; even as the green herb have I given you all things. But flesh with the life thereof, which is the blood thereof, shall ye not eat. And surely your blood of your lives will I require; at the hand of every beast will $I$ require it, and at the hand of man; at the hand of every man's brother will I require the life of man. Whoso sheddeth man's blood, by man shall his blood be shed: for in the image of God made he man. And you, be ye fruitful, and multiply; bring forth abundantly in the earth, and multiply therein.

And God spake unto Noah, and to his sons with him, saying, And I, behold, I establish my covenant with you, and with your seed after you; and with every living creature that is with you, of the fowl, of the cattle, and of every beast of the earth with you; from all that go out of the ark, to every beast of the earth. And I will establish my covenant with you; neither shall all flesh be cut off any more by the waters of a flood; neither shall there any 
more be a flood to destroy the earth. And God said, This is the token of the covenant which I make between me and you and every living creature that is with you, for perpetual generations: I do set my bow in the cloud, and it shall be for a token of a covenant between me and the earth. And it shall come to pass, when I bring a cloud over the earth, that the bow shall be seen in the cloud: and I will remember my covenant, which is between me and you and every living creature of all flesh; and the waters shall no more become a flood to destroy all flesh. And the bow shall be in the cloud; and I will look upon it, that I may remember the everlasting covenant between God and every living creature of all flesh that is upon the earth. And God said unto Noah, This is the token of the covenant, which I have established between me and all flesh that is upon the earth.

\section{V.}

\section{The Tower of fbabel.}

Genesis xi. I-9.

AND the whole earth was of one language, and of one speech. And it came to pass, as they journeyed from the east, that they found a plain in the land of Shinar; and they dwelt there. And they said one to another, Go to, let us make brick, and burn them throughly. And they had brick for" stone, and slime had they for morter. And they said, Go to, let us build us a city and a tower, whose top 
may reach unto heaven; and let us make us a name, lest we be scattered abroad upon the face of the whole earth. And the Lord came down to see the city and the tower, which the children of men builded. And the Lord said, Behold, the people is one, and they have all one language; and this they begin to do: and now nothing will be restrained from them, which they have imagined to do. Go to, let us go down, and there confound their language, that they may not understand one another's speech. So the Lord scattered them abroad from thence upon the face of all the earth: and they left off to build the city. Therefore is the name of it called Babel; because the Lord did there confound the language of all the earth: and from thence did the Lord scatter them abroad upon the face of all the earth.

\section{VI.}

\section{ZAbrabam.}

\section{(a) The Call of Abrahaim.}

Genesis xii. I-7.

Now the Lord had said unto Abram, Get thee out of thy country, and from thy kindred, and from thy father's house, unto a land that I will shew thee: and I will make of thee a great nation, and I will bless thee, and make thy name great; and thou shalt be a blessing: and I will bless them that bless thee, and curse him that curseth thee: and in thee shall all families of the earth be blessed. So Abram departed, as the Lord had spoken unto him; 
and Lot went with him: and Abram was seventy and five years old when he departed out of Haran. And Abram took Sarai his wife, and Lot his brother's son, and all their substance that they had gathered, and the souls that they had gotten in Haran; and they went forth to go into the land of Canaan; and into the land of Canaan they came.

And Abram passed through the land unto the place of Sichem, unto the plain of Moreh. And the Canaanite was then in the land. And the Lord appeared unto Abram, and said, Unto thy seed will I give this land: and there builded he an altar unto the Lord, who appeared unto him.

\section{(b) The Covenant with Abraham.}

Genesis xvii. I-8.

AND when Abram was ninety years old and nine, the Lord appeared to Abram, and said unto him, I am the Almighty God; walk before me, and be thou perfect. And I will make my covenant between me and thee, and will multiply thee exceedingly. And Abram fell on his face: and God talked with him, saying, As for me, behold, my covenant is with thee, and thou shalt be a father of many nations. Neither shall thy name any more be called Abram, but thy name shall be Abraham [i.e. "Father of a great multitude"]; for a father of many nations have I made thee. And I will make thee exceeding fruitful, and I will make nations of thee, and kings shall come out of thee. And I will establish my covenant between me and thee and thy seed after thee in their generations for an everlast- 
ing covenant, to be a God unto thee, and to thy seed after thee. And I will give unto thee, and to thy seed after thee, the land wherein thou art a stranger, all the land of Canaan, for an everlasting possession; and I will be their God.

\section{VII. \\ The Destruction of $\$ 000 \mathrm{~m}$ and Gomorrab.}

Genesis xviii. 16-33; xix. I2-29.

And the men [three angels whom Abraham had entertained unawares] rose up from thence, and looked toward Sodom: and Abraham went with them to bring them on the way. And the Lord said, Shall I hide from Abraham that thing which I do; seeing that Abraham shall surely become a great and mighty nation, and all the nations of the earth shall be blessed in him? For I know him, that he will command his children and his household after him, and they shall keep the way of the Lord, to do justice and judgment; that the Lord may bring upon Abraham that which he hath spoken of him. And the Lord said, Because the cry of Sodom and Gomorrah is great, and because their sin is very grievous; I will go down now, and see whether they have done altogether according to the cry of it, which is come unto me; and if not, I will know. And the men turned their faces from thence, and went toward Sodom: but Abraham stood yet before the Lord.

And Abraham drew near, and said, Wilt thou 
also destroy the righteous with the wicked? Peradventure there be fifty righteous within the city: wilt thou also destroy and not spare the place for the fifty righteous that are therein? That be far from thee to do after this manner, to slay the righteous with the wicked: and that the righteous should be as the wicked, that be far from thee: shall not the Judge of all the earth do right? And the Lord said, If I find in Sodom fifty righteous within the city, then I will spare all the place for their sakes. And Abraham answered and said, Behold now, I have taken upon me to speak unto the Lord, which am but dust and ashes: peradventure there shall lack five of the fifty righteous: wilt thou destroy all the city for lack of five? And he said, If I find there forty and five, I will not destroy it. And he spake unto him yet again, and said, Peradventure there shall be forty found there. And he said, I will not do it for forty's sake. And he said unto him, Oh let not the Lord be angry, and I will speak: peradventure there shall thirty be found there. And he said, I will not do it, if I find thirty there. And he said, Behold now, I have taken upon me to speak unto the Lord: peradventure there shall be twenty found there. And he said, I will not destroy it for twenty's sake. And he said, Oh let not the Lord be angry, and I will speak yet but this once: peradventure ten shall be found there. And he said, I will not destroy it for ten's sake. And the Lord went his way, as soon as he had left communing with Abraham: and Abraham returned unto his place. 
And the men [two angels who had visited Lot] said unto Lot, Hast thou here any besides? son in law, and thy sons, and thy daughters, and whatsoever thou hast in the city, bring them out of this place: for we will destroy this place, because the cry of them is waxen great before the face of the Lord; and the Lord hath sent us to destroy it. And Lot went out, and spake unto his sons in law, which married his daughters, and said, Up, get you out of this place; for the Lord will destroy this city. But he seemed as one that mocked unto his sons in law.

And when the morning arose, then the angels hastened Lot, saying, Arise, take thy wife, and thy two daughters, which are here; lest thou be consumed in the iniquity of the city. And while he lingered, the men laid hold upon his hand, and upon the hand of his wife, and upon the hand of his two daughters; the Lord being merciful unto him: and they brought him forth, and set him without the city. And it came to pass, when they had brought them forth abroad, that he said, Escape for thy life; look not behind thee, neither stay thou in all the plain; escape to the mountain, lest thou be consumed. And Lot said unto them, Oh, not so, my Lord: behold now, thy servant hath found grace in thy sight, and thou hast magnified thy mercy, which thou hast shewed unto me in saving my life; and I cannot escape to the mountain, lest some evil take me, and I die: behold now, this city is near to flee unto, and it is a little one: Oh, let me escape thither, (is it not a little one?) and my soul shall live. And he said unto him, See, I have accepted 
thee concerning this thing also, that $I$ will not overthrow this city, for the which thou hast spoken. Haste thee, escape thither; for I cannot do any thing till thou be come thither. Therefore the name of the city was called Zoar [i.e. "Little"].

The sun was risen upon the earth when Lot entered into Zoar. Then the Lord rained upon Sodom and upon Gomorrah brimstone and fire from the Lord out of heaven; and he overthrew those cities, and all the plain, and all the inhabitants of the cities, and that which grew upon the ground. But his wife looked back from behind him, and she became a pillar of salt. And Abraham gat up early in the morning to the place where he stood before the Lord: and he looked toward Sodom and Gomorrah, and toward all the land of the plain, and beheld, and, lo, the smoke of the country went up as the smoke of a furnace.

And it came to pass, when God destroyed the cities of the plain, that God remembered Abraham, and sent Lot out of the midst of the overthrow, when he overthrew the cities in the which Lot dwelt.

\section{VIII.}

\section{The \$acriffce of IIsaac.}

Genesis xxii. I-19.

And it came to pass after these things, that God did tempt Abraham, and said unto him, Abraham: and he said, Behold, here I am. And he said, Take now thy son, thine only son Isaac, whom thon 
lovest, and get thee into the land of Moriah; and offer him there for a burnt offering upon one of the mountains which I will tell thee of.

And Abraham rose up early in the morning, and saddled his ass, and took two of his young men with him, and Isaac his son, and clave the wood for the burnt offering, and rose up, and went unto the place of which God had told him. Then on the third day Abraham lifted up his eyes, and saw the place afar off. And Abraham said unto his young men, Abide ye here with the ass; and I and the lad will go yonder and worship, and come again to you. And Abraham took the wood of the burnt offering, and laid it upon Isaac his son; and he took the fire in his hand, and a knife; and they went both of them together. And Isaac spake unto Abraham his father, and said, My father: and he said, Here am I, my son. And he said, Behold the fire and the wood: but where is the lamb for a burnt offering? And Abraham said, My son, God will provide himself a lamb for a burnt offering: so they went both of them together.

And they came to the place which God had told him of; and Abraham built an altar there, and laid the wood in order, and bound Isaac his son, and laid him on the altar upon the wood. And Abraham stretched forth his hand, and took the knife to slay his son. And the angel of the Lord called unto him out of heaven, and said, Abraham, Abraham: and he said, Here am I. And he said, Lay not thine hand upon the lad, neither do thou any thing unto him: for now I know that thou fearest God, seeing thou hast not withheld thy son, thine 
only son from me. And Abraham lifted up his eyes, and looked, and behold behind him a ram caught in a thicket by his horns : and Abraham went and took the ram, and offered him up for a burnt offering in the stead of his son. And Abraham called the name of that place Jehovah-jireh [i.e. "The Lord will see, or provide"] : as it is said to this day, In the mount of the Lord it shall be seen.

And the angel of the Lord called unto Abraham out of heaven the second time, and said, By myself have I sworn, saith the Lord, for because thou hast done this thing, and hast not withheld thy son, thine only son: that in blessing I will bless thee, and in multiplying I will multiply thy seed as the stars of the heaven, and as the sand which is upon the sea shore; and thy seed shall possess the gate of his enemies; and in thy seed shall all the nations of the earth be blessed; because thou hast obeyed my voice. So Abraham returned unto the young men, and they rose up and went together to Beersheba; and Abraham dwelt at Beer-sheba.

\section{IX.}

\section{Tbe vollooing of tRebekab.}

Genesis xxiv.

And Abraham was old, and well stricken in age: and the Lord had blessed Abraham in all things. And Abraham said unto his eldest servant of his house, that ruled over all that he had, Put, I pray thee, thy hand under my thigh: and I will make 
thee swear by the Lord, the God of heaven, and the God of the earth, that thou shalt not take a wife unto my son of the daughters of the Canaanites, among whom I dwell: but thou shalt go unto my country, and to my kindred, and take a wife unto my son Isaac. And the servant said unto him, Peradventure the woman will not be willing to follow me unto this land: must I needs bring thy son again unto the land from whence thou camest? And Abraham said unto him, Beware thou that thou bring not my son thither again. The Lord God of heaven, which took me from my father's house, and from the land of my kindred, and which spake unto me, and that sware unto me, saying, Unto thy seed will I give this land; he shall send his angel before thee, and thou shalt take a wife unto my son from thence. And if the woman will not be willing to follow thee, then thou shalt be clear from this my oath: only bring not my son thither again. And the servant put his hand under the thigh of Abraham his master, and sware to him concerning that matter.

And the servant took ten camels of the camels of his master, and departed; for all the goods of his master were in his hand: and he arose, and went to Mesopotamia, unto the city of Nahor. And he made his camels to kneel down without the city by a well of water at the time of the evening, even the time that women go out to draw water. And he said, O Lord God of my master Abraham, I pray thee, send me good speed this day, and shew kindness unto my master Abraham. Behold, I stand here by the well of water; and the daughters of the 
men of the city come out to draw water: and let it come to pass, that the damsel to whom I shall say, Let down thy pitcher, I pray thee, that I may drink; and she shall say, Drink, and I will give thy camels drink also: let the same be she that thou hast appointed for thy servant Isaac; and thereby shall I know that thou hast shewed kindness unto my master.

And it came to pass, before he had done speaking, that, behold, Rebekah came out, who was born to Bethuel, son of Milcah, the wife of Nahor, Abraham's brother, with her pitcher upon her shoulder. And the damsel was very fair to look upon, a virgin, neither had any man known her: and she went down to the well, and filled her pitcher, and came up. And the servant ran to meet her, and said, Let me, I pray thee, drink a little water of thy pitcher. And she said, Drink, my lord: and she hasted, and let down her pitcher upon her hand, and gave him drink. And when she had done giving him drink, she said, I will draw water for thy camels also, until they have done drinking. And she hasted, and emptied her pitcher into the trough, and ran again unto the well to draw water, and drew for all his camels. And the man wondering at her held his peace, to wit whether the Lord had made his journey prosperous or not. And it came to pass, as the camels had done drinking, that the man took a golden earring of half a shekel weight, and two bracelets for her hands of ten shekels weight of gold; and said, Whose daughter art thou? tell me, I pray thee: is there room in thy father's house for us to lodge in? And she said unto him, I am the 
daughter of Bethuel the son of Milcah, which she bare unto Nahor. She said moreover unto him, We have both straw and provender enough, and room to lodge in. And the man bowed down his head, and worshipped the Lord. And he said, Blessed be the Lord God of my master Abraham, who hath not left destitute my master of his mercy and his truth: I being in the way, the Lord led me to the house of my master's brethren. And the damsel ran, and told them of her mother's house these things.

And Rebekah had a brother, and his name was Laban: and Laban ran out unto the man, unto the well. And it came to pass, when he saw the earring and bracelets upon his sister's hands, and when he heard the words of Rebekah his sister, saying, Thus spake the man unto me; that he came unto the man; and, behold, he stood by the camels at the well. And he said, Come in, thon blessed of the Lord; wherefore standest thou without? for I have prepared the house, and room for the camels. And the man came into the house: and he ungirded his camels, and gave straw and provender for the camels, and water to wash his feet, and the men's feet that were with him. And there was set meat before him to eat: but he said, I will not eat, until I have told mine errand. And he said, Speak on.

And he said, I am Abraham's servant. And the Lord hath blessed my master greatly; and he is become great: and he hath given him flocks, and herds, and silver, and gold, and menservants, and maidservants, and camels, and asses. And Sarah 
my master's wife bare a son to my master when she was old: and unto him hath he given all that he hath. And my master made me swear, saying, Thou shalt not take a wife to my son of the daughters of the Canaanites, in whose land I dwell: but thou shalt go unto my father's house, and to my kindred, and take a wife unto my son. And I said unto my master, Peradventure the woman will not follow me. And he said unto me, The Lord, before whom I walk, will send his angel with thee, and prosper thy way; and thou shalt take a wife for my son of my kindred, and of my father's house: then shalt thou be clear from this my oath, when thou comest to my kindred; and if they give not thee one, thou shalt be ciear from my oath. And I came this day unto the well, and said, O Lord God of my master Abraham, if now thou do prosper my way which I go: behold, I stand by the well of water; and it shall come to pass, that when the virgin cometh forth to draw water, and I say to her, Give me, I pray thee, a little water of thy pitcher to drink; and she say to me, Both drink thou, and I will also draw for thy camels: let the same be the woman whom the Lord hath appointed out for my master's son. And before I had done speaking in mine heart, behold, Rebekah came forth with her pitcher on her shoulder; and she went down unto the well, and drew water: and I said unto her, Let me drink, I pray thee. And she made haste, and let down her pitcher from her shoulder, and said, Drink, and I will give thy camels drink also: so I drank, and she made the camels drink also. And I asked her, and said, Whose daughter 
art thou? And she said, The daughter of Bethuel, Nahor's son, whom Milcah bare unto him: and I put the earring upon her face, and the bracelets upon her hands. And I bowed down my head, and worshipped the Lord, and blessed the Lord God of my master Abraham, which had led me in the right way to take my master's brother's daughter unto his son. And now if you will deal kindly and truly with my master, tell me: and if not, tell me; that I may turn to the right hand, or to the left.

Then Laban and Bethuel answered and said, The thing proceedeth from the Lord: we cannot speak unto thee bad or good. Behold, Rebekah is before thee, take her, and go, and let her be thy master's son's wife, as the Lord hath spoken. And it came to pass, that, when Abraham's servant heard their words, he worshipped the Lord, bowing himself to the earth. And the servant brought forth jewels of silver, and jewels of gold, and raiment, and gave them to Rebekah: he gave also to her brother and to her mother precious things.

And they did eat and drink, he and the men that were with him, and tarried all night; and they rose up in the morning, and he said, Send me away unto my master. And her brother and her mother said, Let the damsel abicle with us a few days, at the least ten; after that she shall go. And he said unto them, Hinder me not, seeing the Lord hath prospered my way; send me away that I may go to my master. And they said, We will call the damsel, and enquire at her mouth. And they called Rebekah, and said unto her, Wilt thou go with this man? And she said, I will go. And they sent away 
Rebekah their sister, and her nurse, and Abraham's servant, and his men. And they blessed Rebekah, and said unto her, Thou art our sister, be thou the mother of thousands of millions, and let thy seed possess the gate of those which hate them.

And Rebekah arose and her damsels, and they rode upon the camels, and followed the man: and the servant took Rebekah, and went his way. And Isaac came from the way of the well Lahai-roi; for he dwelt in the south country. And Isaac went out to meditate in the field at the eventide: and he lifted up his eyes, and saw, and, behold, the camels were coming. And Rebekah lifted up her eyes, and when she saw Isaac, she lighted off the camel. For she had said unto the servant, What man is this that walketh in the field to meet us? And the servant had said, It is my master: therefore she took a vail, and covered herself. And the servant told Isaac all things that he had done. And Isaac brought her into his mother Sarah's tent, and took Rebekah, and she became his wife; and he loved her: and Isaac was comforted after his mother's death.

\section{$\mathrm{X}$.}

\section{Esau allo $\mathcal{F}$ acob.}

Genesis xxv. 27-34 ; xxvii.-xxviii. 5 ; xxviii. I0-xxix. 30 ; xxxii.-xxxiii. I 7 .

AND the boys grew: and Esau was a cunning hunter, a man of the field; and Jacob was a plain man, dwelling in tents. And Isaac loved Esau, because he did eat of his venison: but Rebekah loved 
Jacob. And Jacob sod pottage: and Esau came from the field, and he was faint: and Esau said to Jacob, Feed me, I pray thee, with that same red pottage; for I am faint: therefore was his name called Edom [i.e. "Red"]. And Jacob said, Sell me this day thy birthright. And Esau said, Behold, I am at the point to die: and what profit shall this birthright do to me? And Jacob said, Swear to me this day; and he sware unto him: and he sold his birthright unto Jacob. Then Jacob gave Esau bread and pottage of lentiles; and he did eat and drink, and rose up, and went his way. Thus Esau despised his birthright.

And it came to pass, that when Isaac was old, and his eyes were dim, so that he could not see, he called Esau his eldest son, and said unto him, My son: and he said unto him, Behold, here am I. And he said, Behold now, I am old, I know not the day of my death: now therefore take, I pray thee, thy weapons, thy quiver and thy bow, and go out to the field, and take me some venison; and make me savoury meat, such as I love, and bring it to me, that I may eat; that my soul may bless thee before I die.

And Rebekah heard when Isaac spake to Esau his son. And Esau went to the field to hunt for venison, and to bring it. And Rebekah spake unto Jacob her son, saying, Behold, I heard thy father speak unto Esau thy brother, saying, Bring me venison, and make me savoury meat, that I may eat, and bless thee before the Lord before my death. Now therefore, my son, obey my voice according 
to that which I command thee. Go now to the flock, and fetch me from thence two good kids of the goats; and I will make them savoury meat for thy father, such as he loveth: and thou shalt bring it to thy father, that he may eat, and that he may bless thee before his death. And Jacob said to Rebekah his mother, Behold, Esau my brother is a hairy man, and I am a smooth man: my father peradventure will feel me, and I shall seem to him as a deceiver; and I shall bring a curse upon me, and not a blessing. And his mother said unto him, Upon me be thy curse, my son: only obey my voice, and go fetch me them. And he went, and fetched, and brought them to his mother: and his mother made savoury meat, such as his father loved. And Rebekah took goodly raiment of her eldest son Esau, which were with her in the house, and put them upon Jacob her younger son: and she put the skins of the kids of the goats upon his hands, and upon the smooth of his neck: and she gave the savoury meat and the bread, which she had prepared, into the hand of her son Jacob.

And he came unto his father, and said, My father: and he said, Here am I; who art thou, my son? And Jacob said unto his father, I am Esau thy firstborn; I have done according as thou badest me: arise, I pray thee, sit and eat of my venison, that thy soul may bless me. And Isaac said unto his son, How is it that thou hast found it so quickly, my son? And he said, Because the Lord thy God brought it to me. And Isaac said unto Jacob, Come near, I pray thee, that I may feel thee, my son, whether thou be my very son Esau or not. 
And Jacob went near unto Isaac his father; and he felt him, and said, The voice is Jacob's voice, but the hands are the hands of Esau. And he discerned him not, because his hands were hairy, as his brother Esau's hands: so he blessed him. And he said, Art thou my very son Esau? And he said, I am. And he said, Bring it near to me, and I will eat of my son's venison, that my soul may bless thee. And he brought it near to him, and he did eat: and he brought him wine, and he drank. And his father Isaac said unto him, Come near now, and kiss me, my son. And he came near, and kissed him: and he smelled the smell of his raiment, and blessed him, and said, See, the smell of my son is as the smell of a field which the Lord hath blessed: therefore God give thee of the dew of heaven, and the fatness of the earth, and plenty of corn and wine: let people serve thee, and nations bow down to thee: be lord over thy brethren, and let thy mother's sons bow down to thee: cursed be every one that curseth thee, and blessed be he that blesseth thee.

And it came to pass, as soon as Isaac had made an end of blessing Jacob, and Jacob was yet scarce gone out from the presence of Isaac his father, that Esau his brother came in from his hunting. And he also had made savoury meat, and brought it unto his father, and said unto his father, Let my father arise, and eat of his son's venison, that thy soul may bless me. And Isaac his father said unto him, Who art thou? And he said, I am thy son, thy firstborn Esau. And Isaac trembled very exceedingly, and said, Who? where is he that hath 
taken venison, and brought it me, and I have eaten of all before thou camest, and have blessed him? yea, and he shall be blessed. And when Esau heard the words of his father, he cried with a great and exceeding bitter cry, and said unto his father, Bless me, even me also, O my father. And he said, Thy brother came with subtilty, and hath taken away thy blessing. And he said, Is not he rightly named Jacob [i.e. "One that supplants"] ? for he hath supplanted me these two times: he took away my birthright; and, behold, now he hath taken away my blessing. And he said, Hast thou not reserved a blessing for me? And Isaac answered and said unto Esau, Behold, I have made him thy lord, and all his brethren have I given to him for servants; and with corn and wine have I sustained him: and what shall I do now unto thee, my son? And Esau said unto his father, Hast thou but one blessing, my father? bless me, even me also, $\mathrm{O}$ my father. And Esau lifted up his voice, and wept. And Isaac his father answered and said unto him, Behold, thy dwelling shall be the fatness of the earth, and of the dew of heaven from above; and by thy sword shalt thou live, and shalt serve thy brother; and it shall come to pass when thou shalt have the dominion, that thou shalt break his yoke from off thy neck.

And Esau hated Jacob because of the blessing wherewith his father blessed him: and Esau said in his heart, The days of mourning for my father are at hand; then will I slay my brother Jacob. And these words of Esau her elder son were told to Rebekah : and she sent and called Jacob her younger 
son, and said unto him, Behold, thy brother Esau, as touching thee, doth comfort himself, purposing to kill thee. Now therefore, my son, obey my voice; and arise, flee thou to Laban my brother to Haran; and tarry with him a few days, until thy brother's fury turn away; until thy brother's anger turn away from thee, and he forget that which thou hast done to him: then I will send, and fetch thee from thence: why should I be deprived also of you both in one day? And Rebekah said to Isaac, I am weary of my life because of the daughters of Heth: if Jacob take a wife of the daughters of Heth, such as these which are of the daughters of the land, what good shall my life do me?

And Isaac called Jacob, and blessed him, and charged him, and said unto him, Thou shalt not take a wife of the daughters of Canaan. Arise, go to Padan-aram, to the house of Bethuel thy mother's father; and take thee a wife from thence of the daughters of Laban thy mother's brother. And God Almighty bless thee, and make thee fruitful, and multiply thee, that thou mayest be a multitude of people; and give thee the blessing of Abraham, to thee, and to thy seed with thee; that thou mayest inherit the land wherein thou art a stranger, which God gave unto Abraham. And Isaac sent away Jacob: and he went to Padan-aram unto Laban, son of Bethuel the Syrian, the brother of Rebekah, Jacob's and Esau's mother.

And Jacob went out from Beer-sheba, and went toward Haran. And he lighted upon a certain 
place, and tarried there all night, because the sun was set; and he took of the stones of that place, and put them for his pillows, and lay down in that place to sleep. And he dreamed, and behold a ladder set up on the earth, and the top of it reached to heaven: and behold the angels of God ascending and descending on it. And, behold, the Lord stood above it, and said, I am the Lord God of Abraham thy father, and the God of Isaac: the land whereon thou liest, to thee will I give it, and to thy seed; and thy seed shall be as the dust of the earth; and thou shalt spread abroad to the west, and to the east, and to the north, and to the south: and in thee and in thy seed shall all the families of the earth be blessed. And, behold, I am with thee, and will keep thee in all places whither thou goest, and will bring thee again into this land; for I will not leave thee, until I have done that which I have spoken to thee of.

And Jacob awaked out of his sleep, and he said, Surely the Lord is in this place; and I knew it not. And he was afraid, and said, How dreadful is this place! this is none other but the house of God, and this is the gate of heaven. And Jacob rose up early in the morning, and took the stone that he had put for his pillows, and set it up for a pillar, and poured oil upon the top of it. And he called the name of that place Beth-el [i.e. "The house of God "] : but the name of that city was called Luz at the first. And Jacob vowed a vow, saying, If God will be with me, and will keep me in this way that I go, and will give me bread to eat, and raiment to put on, so that I come again to my father's house in 
peace; then shall the Lord be my God: and this -stone, which I have set for a pillar, shall be God's house: and of all that thou shalt give me I will surely give the tenth unto thee.

Then Jacob went on his journey, and came into the land of the people of the east. And he looked, and behold a well in the field, and, lo, there were three flocks of sheep lying by it ; for out of that well they watered the flocks: and a great stone was upon the well's mouth. And thither were all the flocks gathered: and they rolled the stone from the well's mouth, and watered the sheep, and put the stone again upon the well's mouth in his place. And Jacob said unto them, My brethren, whence be ye? And they said, Of Haran are we. And he said unto them, Know ye Laban the son of Nahor? And they said, We know him. And he said unto them, Is he well? And they said, He is well: and, behold, Rachel his daughter cometh with the sheep. And he said, Lo, it is yet high day, neither is it time that the cattle should be gathered together: water ye the sheep, and go and feed them. And they said, We cannot, until all the flocks be gathered together, and till they roll the stone from the well's mouth; then we water the sheep.

And while he yet spake with them, Rachel came with her father's sheep: for she kept them. And it came to pass, when Jacob saw Rachel the daughter of Laban his mother's brother, and the sheep of Laban his mother's brother, that Jacob went near, and rolled the stone from the well's mouth, and watered the flock of Laban his mother's brother. And Jacob kissed Rachel, and lifted up his voice, 
and wept. And Jacob told Rachel that he was her father's brother, and that he was Rebekah's son:and she ran and told her father. And it came to pass, when Laban heard the tidings of Jacob his sister's son, that he ran to meet him, and embraced him, and kissed him, and brought him to his house. And he told Laban all these things. And Laban said to him, Surely thou art my bone and my flesh. And he abode with him the space of a month.

And Laban said unto Jacob, Because thou art my brother, shouldest thou therefore serve me for nought? tell me, what shall thy wages be? And Laban had two daughters: the name of the elder was Leah, and the name of the younger was Rachel. Leah was tender eyed; but Rachel was beautiful and well favoured. And Jacob loved Rachel; and said, I will serve thee seven years for Rachel thy younger daughter. And Laban said, It is better that I give her to thee, than that I should give her to another man: abide with me. And Jacob served seven years for Rachel; and they seemed unto him but a few days, for the love he had to her.

And Jacob said unto Laban, Give me my wife, for my days are fulfilled, that I may go in unto her. And Laban gathered together all the men of the place, and made a feast. And it came to pass in the evening, that he took Leah his daughter, and brought her to him; and he went in unto her. And Laban gave unto his daughter Leah Zilpah his maid for an handmaid. And it came to pass, that in the morning, behold, it was Leah: and he said to Laban, What is this thou hast done unto me? did not I serve with thee for Rachel? wherefore then hast 
thou beguiled me? And Laban said, It must not be so done in our country, to give the younger before the firstborn. Fulfil her week, and we will give thee this also for the service which thou shalt serve with me yet seven other years. And Jacob did so, and fulfilled her week: and he gave him Rachel his daughter to wife also. And Laban gave to Rachel his daughter Bilhah his handmaid to be her maid. And he went in also unto Rachel, and he loved also Rachel more than Leah, and served with him yet seven other years.

And Jacob went on his way, and the angels of God met him. And when Jacob saw them, he said, This is God's host: and he called the name of that place Mahanaim [i.e. "Hosts," or "Companies"]. And Jacob sent messengers before him to Esau his brother unto the land of Seir, the country of Edom. And he commanded them, saying, Thus shall ye speak unto my lord Esau; Thy servant Jacob saith thus, I have sojourned with Laban, and stayed there until now : and I have oxen, and asses, flocks, and menservants, and womenservants : and I have sent to tell my lord, that I may find grace in thy sight. And the messengers returned to Jacob, saying, We came to thy brother Esau, and also he cometh to meet thee, and four hundred men with him. Then Jacob was greatly afraid and distressed : and he divided the people that was with him, and the flocks, and herds, and the camels, into two bands; and said, If Esau come to the one company, and smite it, then the other company which is left shall escape. 
And Jacob said, O God of my father Abraham, and God of my father Isaac, the Lord which saidst unto me, Return unto thy country, and to thy kindred, and I will deal well with thee: I am not worthy of the least of all the mercies, and of all the truth, which thou hast shewed unto thy servant; for with my staff I passed over this Jordan; and now I am become two bands. Deliver me, I pray thee, from the hand of my brother, from the hand of Esau: for I fear him, lest he will come and smite me, and the mother with the children. And thou saidst, I will surely do thee good, and make thy seed as the sand of the sea, which cannot be numbered for multitude.

And he lodged there that same night, and took of that which came to his hand a present for Esau his brother; two hundred she goats, and twenty he goats, two hundred ewes, and twenty rams, thirty milch camels with their colts, forty kine, and ten bulls, twenty she asses, and ten foals. And he delivered them into the hand of his servants, every drove by themselves; and said unto his servants, Pass over before me, and put a space betwixt drove and drove. And he commanded the foremost, saying, When Esau my brother meeteth thee, and asketh thee, saying, Whose art thou? and whither goest thou? and whose are these before thee? Then thou shalt say, They be thy servant Jacob's; it is a present sent unto my lord Esau: and, behold, also he is behind us. And so commanded he the second, and the third, and all that followed the droves, saying, On this manner shall ye speak unto Esau, when ye find him. And say ye moreover, Behold, 
thy servant Jacob is behind us. For he said, I will appease him with the present that goeth before me, and afterward I will see his face; peradventure he will accept of me. So went the present over before him: and himself lodged that night in the company. And he rose up that night, and took his two wives, and his two womenservants, and his eleven sons, and passed over the ford Jabbok. And he took them, and sent them over the brook, and sent over that he had.

And Jacob was left alone; and there wrestled a man with him until the breaking of the day. And when he saw that he prevailed not against him, he touched the hollow of his thigh; and the hollow of Jacob's thigh was out of joint, as he wrestled with him. And he said, Let me go, for the day breaketh. And he said, I will not let thee go, except thou bless me. And he said unto him, What is thy name? And he said, Jacob. And he said, Thy name shall be called no more Jacob, but Israel [i.e. "He who striveth with God"] : for as a prince hast thou power with God and with men, and hast prevailed. And Jacob asked him, and said, Tell me, I pray thee, thy name. And he said, Wherefore is it that thou dost ask after my name? And he blessed him there. And Jacob called the name of the place Peniel [i.e. "The face of God"] : for I have seen God face to face, and my life is preserved. And as he passed over Penuel the sun rose upon him, and he halted upon his thigh. Therefore the children of Israel eat not of the sinew which shrank, which is upon the hollow of the thigh, unto this day: because he touched 
the hollow of Jacob's thigh in the sinew that shrank.

And Jacob lifted up his eyes, and looked, and, behold, Esau came, and with him four hundred men. And he divided the children unto Leah, and unto Rachel, and unto the two handmaids. And he put the handmaids and their children foremost, and Leah and her children after, and Rachel and Joseph hindermost. And he passed over before them, and bowed himself to the ground seven times, until he came near to his brother. And Esau ran to meet him, and embraced him, and fell on his neck, and kissed him: and they wept. And he lifted up his eyes, and saw the women and the children; and said, Who are those with thee? And he said, The children which God hath graciously given thy servant. Then the handmaidens came near, they and their children, and they bowed themselves. And Leah also with her children came near, and bowed themselves: and after came Joseph near and Rachel, and they bowed themselves.

And he said, What meanest thou by all this drove which I met? And he said, These are to find grace in the sight of my lord. And Esau said, I have enough, my brother; keep that thou hast unto thyself. And Jacob said, Nay, I pray thee, if now I have found grace in thy sight, then receive my present at my hand: for therefore I have seen thy face, as though I had seen the face of God, and thou wast pleased with me. Take, I pray thee, my blessing that is brought to thee; because God hath dealt graciously with me, and because I have enough. And he urged him, and he took it. And 
he said, Let us take our journey, and let us go, and I will go before thee. And he said unto him, My lord knoweth that the children are tender, and the flocks and herds with young are with me: and if men should overdrive them one day, all the flock will die. Let my lord, I pray thee, pass over before his servant: and I will lead on softly, according as the cattle that goeth before me and the children be able to endure, until I come unto my lord unto Seir. And Esau said, Let me now leave with thee some of the folk that are with me. And he said, What needeth it? let me find grace in the sight of my lord.

So Esau returned that day on his way unto Seir. And Jacob journeyed to Succoth, and built him an house, and made booths for his cattle: therefore the name of the place is called Succoth [i.e. "Booths"].

\section{XI.}

Fosepb and bis JBretbren.

Genesis xxxvii.; xxxix.-xlvi. 7 ; xlvi. 28-xlvii. 12.

And Jacob dwelt in the land wherein his father was a stranger, in the land of Canaan. These are the generations of Jacob. Joseph, being seventeen years old, was feeding the flock with his brethren; and the lad was with the sons of Bilhah, and with the sons of Zilpah, his father's wives: and Joseph brought unto his father their evil report. Now Israel loved Joseph more than all his children, because he was the son of his old age: and he made him a coat of many colours. And when his brethren 
saw that their father loved him more than all his brethren, they hated him, and could not speak peaceably unto him.

And Joseph dreamed a dream, and he told it his brethren: and they hated him yet the more. And he said unto them, Hear, I pray you, this dream which I have dreamed: for, behold, we were binding sheaves in the field, and, lo, my sheaf arose, and also stood upright; and, behold, your sheaves stood round about, and made obeisance to my sheaf. And his brethren said to him, Shalt thou indeed reign over us? or shalt thou indeed have dominion over us? And they hated him yet the more for his dreams, and for his words. And he dreamed yet another dream, and told it his brethren, and said, Behold, I have dreamed a dream more; and, behold, the sun and the moon and the eleven stars made obeisance to me. And he told it to his father, and to his brethren: and his father rebuked him, and said unto him, What is this dream that thou hast dreamed? Shall I and thy mother and thy brethren indeed come to bow down ourselves to thee to the earth? And his brethren envied him; but his father observed the saying.

And his brethren went to feed their father's flock in Shechem. And Israel said unto Joseph, Do not thy brethren feed the flock in Shechem? come, and I will send thee unto them. And he said to him, Here am I. And he said to him, Go, I pray thee, see whether it be well with thy brethren, and well with the flocks; and bring me word again. So he sent him out of the vale of Hebron, and he came to Shechem. And a certain man found him, and, 
behold, he was wandering in the field: and the man asked him, saying, What seekest thou? And he said, I seek my brethren : tell me, I pray thee, where they feed their flocks. And the man said, They are departed hence; for I heard them say, Let us go to Dothan. And Joseph went after his brethren, and found them in Dothan. And when they saw him afar off, even before he came near unto them, they conspired against him to slay him. And they said one to another, Behold, this dreamer cometh. Come now therefore, and let us slay him, and cast him into some pit, and we will say, Some evil beast hath devoured him: and we shall see what will become of his dreams. And Reuben heard it, and he delivered him out of their hands; and said, Let us not kill him. And Reuben said unto them, Shed no blood, but cast him into this pit that is in the wilderness, and lay no hand upon him; that he might rid him out of their hands, to deliver him to his father again.

And it came to pass, when Joseph was come unto his brethren, that they stript Joseph out of his coat, his coat of many colours that was on him; and they took him, and cast him into a pit: and the pit was empty, there was no water in it. And they sat down to eat bread: and they lifted up their eyes and looked, and, behold, a company of Ishmeelites came from Gilead with their camels bearing spicery and balm and myrrh, going to carry it down to Egypt. And Judah said unto his brethren, What profit is it if we slay our brother, and conceal his blood? Come, and let us sell him to the Ishmeelites, and let not our hand be upon him; for he is our 
brother and our flesh. And his brethren were content. Then there passed by Midianites merchantmen; and they drew and lifted up Joseph out of the pit, and sold Joseph to the Ishmeelites for twenty pieces of silver: and they brought Joseph into Egypt.

And Reuben returned unto the pit; and, behold, Joseph was not in the pit; and he rent his clothes. And he returned unto his brethren, and said, The child is not; and I, whither shall I go? And they took Joseph's coat, and killed a kid of the goats, and dipped the coat in the blood; and they sent the coat of many colours, and they brought it to their father; and said, This have we found: know now whether it be thy son's coat or no. And he knew it, and said, It is my son's coat; an evil beast hath devoured him; Joseph is without doubt rent in pieces. And Jacob rent his clothes, and put sackcloth upon his loins, and mourned for his son many days. And all his sons and all his daughters rose up to comfort him; but he refused to be comforted; and he said, For I will go down into the grave unto my son mourning. Thus his father wept for him. And the Midianites sold him into Egypt unto Potiphar, an officer of Pharaoh's, and captain of the guard.

And Joseph was brought down to Egypt; and Potiphar, an officer of Pharaoh, captain of the guard, an Egyptian, bought him of the hands of the Ishmeelites, which had brought him down thither. And the Lord was with Joseph, and he was a prosperous man; and he was in the house of 
his master the Egyptian. And his master saw that the Lord was with him, and that the Lord made all that he did to prosper in his hand. And Joseph found grace in his sight, and he served him: and he made him overseer over his house, and all that he had he put into his hand. And it came to pass from the time that he had made him overseer in his house, and over all that he had, that the Lord blessed the Egyptian's house for Joseph's sake ; and the blessing of the Lord was upon all that he had in the house, and in the field. And he left all that he had in Joseph's hand; and he knew not ought he had, save the bread which he did eat. And Joseph was a goodly person, and well favoured.

And it came to pass after these things, that his master's wife cast her eyes upon Joseph; and she said, Lie with me. But he refused, and said unto his master's wife, Behold, my master wotteth not what is with me in the house, and he hath committed all that he hath to my hand; there is none greater in this house than I; neither hath he kept back any thing from me but thee, because thou art his wife: how then can I do this great wickedness, and sin against God? And it came to pass, as she spake to Joseph day by day, that he hearkened not unto her, to lie by her, or to be with her.

And it came to pass about this time, that Joseph went into the house to do his business; and there was none of the men of the house there within. And she caught him by his garment, saying, Lie with me: and he left his garment in her hand, and fled, and got him out. And it came to pass, when she saw that he had left his garment in her hand, 
and was fled forth, that she called unto the men of her house, and spake unto them, saying, See, he hath brought in an Hebrew unto us to mock us; he came in unto me to lie with me, and I cried with a loud voice: and it came to pass, when he heard that I lifted up my voice and cried, that he left his garment with me, and fled, and got him out. And she laid up his garment by her, until his lord came home. And she spake unto him according to these words, saying, The Hebrew servant, which thou hast brought unto us, came in unto me to mock me: and it came to pass, as I lifted up my voice and cried, that he left his garment with me, and fled out. And it came to pass, when his master heard the words of his wife, which she spake unto him, saying, After this manner did thy servant to me; that his wrath was kindled. And Joseph's master took him, and put him into the prison, a place where the king's prisoners were bound: and he was there in the prison.

But the Lord was with Joseph, and shewed him mercy, and gave him favour in the sight of the keeper of the prison. And the keeper of the prison committed to Joseph's hand all the prisoners that were in the prison; and whatsoever they did there, he was the doer of it. The keeper of the prison looked not to any thing that was under his hand; because the Lord was with him, and that which he did, the Lord made it to prosper.

And it came to pass after these things, that the butler of the king of Egypt and his baker had offended their lord the king of Egypt. And Pharaoh was wroth against two of his officers, against the 
chief of the butlers, and against the chief of the bakers. And he put them in ward in the house of the captain of the guard, into the prison, the place where Joseph was bound. And the captain of the guard charged Joseph with them, and he served them: and they continued a season in ward.

And they dreamed a dream both of them, each man his dream in one night, each man according to the interpretation of his dream, the butler and the baker of the king of Egypt, which were bound in the prison. And Joseph came in unto them in the morning, and looked upon them, and, behold, they were sad. And he asked Pharaoh's officers that were with him in the ward of his lord's house, saying, Wherefore look ye so sadly to day? And they said unto him, We have dreamed a dream, and there is no interpreter of it. And Joseph said unto them, Do not interpretations belong to God? tell me them, I pray you.

And the chief butler told his dream to Joseph, and said to him, In my dream, behold, a vine was before me; and in the vine were three branches: and it was as though it budded, and her blossoms shot forth; and the clusters thereof brought forth ripe grapes: and Pharaoh's cup was in my hand: and I took the grapes, and pressed them into Pharaoh's cup, and I gave the cup into Pharaoh's hand. And Joseph said unto him, This is the interpretation of it: the three branches are three days: yet within three days shall Pharaoh lift up thine head, and restore thee unto thy place: and thou shalt deliver Pharaoh's cup into his hand, after the former manner when thou wast his butler. But think on 
me when it shall be well with thee, and shew kindness, I pray thee, unto me, and make mention of me unto Pharaoh, and bring me out of this house: for indeed I was stolen away out of the land of the Hebrews: and here also have I done nothing that they should put me into the dungeon.

When the chief baker saw that the interpretation was good, he said unto Joseph, I also was in my dream, and, behold, I had three white baskets on my head: and in the uppermost basket there was of all manner of bakemeats for Pharaoh; and the birds did eat them out of the basket upon my head. And Joseph answered and said, This is the interpretation thereof: the three baskets are three days: yet within three days shall Pharaoh lift up thy head from off thee, and shall hang thee on a tree; and the birds shall eat thy flesh from off thee.

And it came to pass the third day, which was Pharaoh's birthday, that he made a feast unto all his servants: and he lifted up the head of the chief butler and of the chief baker among his servants. And he restored the chief butler unto his butlership again; and he gave the cup into Pharaoh's hand: but he hanged the chief baker: as Joseph had interpreted to them. Yet did not the chief butler remember Joseph, but forgat him.

Ancl it came to pass at the end of two full years, that Pharaoh dreamed: and, behold, he stood by the river. And, behold, there came up out of the river seven well favoured kine and fatfleshed; and they fed in a meadow. And, behold, seven other kine came up after them out of the river, ill favoured and leanfleshed; and stood by the other kine upon 
the brink of the river. And the ill favoured and leanfleshed kine did eat up the seven well favoured and fat kine. So Pharaoh awoke. And he slept and dreamed the second time: and, behold, seven ears of corn came up upon one stalk, rank and good. And, behold, seven thin ears and blasted with the east wind sprung up after them. And the seven thin ears devoured the seven rank and full ears. And Pharaoh awoke, and, behold, it was a dream.

And it came to pass in the morning that his spirit was troubled; and he sent and called for all the magicians of Egypt, and all the wise men thereof: and Pharaol told them his dream; but there was none that could interpret them unto Pharaoh. Then spake the chief butler unto Pharaoh, saying, I do remember my faults this day: Pharaoh was wroth with his servants, and put me in ward in the captain of the guard's house, both me and the chief baker: and we dreamed a dream in one night, I and he; we dreamed each man according to the interpretation of his dream. And there was there with us a young man. an Hebrew, servant to the captain of the guard; and we told him, and he interpreted to us our dreams; to each man according to his dream he did interpret. And it came to pass, as he interpreted to us, so it was; me he restored unto mine office, and him he hanged.

Then Pharaoh sent and called Joseph, and they brought him hastily out of the dungeon: and he shaved himself, and changed his raiment, and came in unto Pharaoh. And Pharaoh said unto Joseph, I have dreamed a dream, and there is none that can interpret it: and I have heard say of thee, that thou 
canst understand a dream to interpret it. And Joseph answered Pharaoh, saying, It is not in me: God shall give Pharaoh an answer of peace. And Pharaoh said unto Joseph, In my dream, behold, I stood upon the bank of the river: and, behold, there came up out of the river seven kine, fatfleshed and well favoured; and they fed in a meadow: and, behold, seven other kine came up after them, poor and very ill favoured and leanfleshed, such as I never saw in all the land of Egypt for badness: and the lean and the ill favoured kine did eat up the first seven fat kine: and when they had eaten them up, it could not be known that they had eaten them; but they were still ill favoured, as at the beginning. So I awoke. And I saw in my dream, and, behold, seven ears came up in one stalk, full and good: and, behold, seven ears, withered, thin, and blasted with the east wind, sprung up after them: and the thin ears devoured the seven good ears: and I told this unto the magicians; but there was none that could declare it to me.

And Joseph said unto Pharaoh, The dream of Pharaoh is one: God hath shewed Pharaoh what he is about to do. The seven good kine are seven years; and the seven good ears are seven years: the dream is one. And the seven thin and ill favoured kine that came up after them are seven years; and the seven empty ears blasted with the east wind shall be seven years of famine. This is the thing which I have spoken unto Pharaoh: what God is about to do he sheweth unto Pharaoh. Behold, there come seven years of great plenty throughout all the land of Egypt: and there shall arise after them 
seven years of famine; and all the plenty shall be forgotten in the land of Egypt; and the famine shall consume the land; and the plenty shall not be known in the land by reason of that famine following; for it shall be very grievous. And for that the dream was doubled unto Pharaoh twice; it is because the thing is established by God, and God will shortly bring it to pass. Now therefore let Pharaoh look out a man discreet and wise, and set him over the land of Egypt. Let Pharaoh do this, and let him appoint officers over the land, and take up the fifth part of the land of Egypt in the seven plenteous years. And let them gather all the food of those good years that come, and lay up corn under the hand of Pharaoh, and let them keep food in the cities. And that food shall be for store to the land against the seven years of famine, which shall be in the land of Egypt; that the land perish not through the famine.

And the thing was good in the eyes of Pharaoh, and in the eyes of all his servants. And Pharaoh said unto his servants, Can we find such a one as this is, a man in whom the Spirit of God is? And Pharaoh said unto Joseph, Forasmuch as God hath shewed thee all this, there is none so discreet and wise as thou art: thou shalt be over my house, and according unto thy word shall all my people be ruled: only in the throne will I be greater than thou. And Pharaoh said unto Joseph, See, I have set thee over all the land of Egypt. And Pharaoh took off his ring from his hand, and put it upon Joseph's hand, and arrayed him in vestures of fine linen, and put a gold chain about his neck; and he made him to 
ride in the second chariot which he had; and they cried before him, Bow the knee: and he made him ruler over all the land of Egypt. And Pharaoh said unto Joseph, I am Pharaoh, and without thee shall no man lift up his hand or foot in all the land of Egypt. And Pharaoh called Joseph's name Zaphnath-paaneah [i.e. "A revealer of secrets"]; and he gave him to wife Asenath the daughter of Poti-pherah priest of On. And Joseph went out over all the land of Egypt.

And Joseph was thirty years old when he stood before Pharaoh king of Egypt. And Joseph went out from the presence of Pharaoh, and went throughout all the land of Egypt. And in the seven plenteous years the earth brought forth by handfuls. And he gathered up all the food of the seven years, which were in the land of Egypt, and laid up the food in the cities: the food of the field, which was round about every city, laid he up in the same. And Joseph gathered corn as the sand of the sea, very much, until he left numbering; for it was without number. And unto Joseph were born two sons, before the years of famine came, which Asenath the daughter of Poti-pherah priest of On bare unto him. And Joseph called the name of the firstborn Manasseh [i.e. "Making to forget"] : For God, said he, hath made me forget all my toil, and all my father's house. And the name of the second called he Ephraim [i.e. "Fruitful"] : For God hath caused me to be fruitful in the land of my affliction.

And the seven years of plenteousness, that was in the land of Egypt, were ended. And the seven 
years of dearth began to come, according as Joseph had said: and the dearth was in all lands; but in all the land of Egypt there was bread. And when all the land of Egypt was famished, the people cried to Pharaoh for bread: and Pharaoh said unto all the Egyptians, Go unto Joseph; what he saith to you, do. And the famine was over all the face of the earth: and Joseph opened all the storehouses, and sold unto the Egyptians; and the famine waxed sore in the land of Egypt. And all countries came into Egypt to Joseph for to buy corn; because that the famine was so sore in all lands.

Now when Jacob saw that there was corn in Egypt, Jacob said unto his sons, Why do ye look one upon another? And he said, Behold, I have heard that there is corn in Egypt: get you down thither, and buy for us from thence; that we may live, and not die. And Joseph's ten brethren went down to buy corn in Egypt. But Benjamin, Joseph's brother, Jacob sent not with his brethren; for he said, Lest peradventure mischief befall him.

And the sons of Israel came to buy corn among those that came: for the famine was in the land of Canaan. And Joseph was the governor over the land, and he it was that sold to all the people of the land: and Joseph's brethren came, and bowed down themselves before him with their faces to the earth. And Joseph saw his brethren, and he knew them, but made himself strange unto them, and spake roughly unto them; and he said unto them, Whence come ye? And they said, From the land of Canaan to buy food. And Joseph knew his brethren, but they knew not him. And Joseph remembered the 
dreams which he dreamed of them, and said unto them, Ye are spies; to see the nakedness of the land ye are come. And they said unto him, Nay, my lord, but to buy food are thy servants come. We are all one man's sons; we are true men, thy servants are no spies. And he said unto them, Nay, but to see the nakedness of the land ye are come. And they said, Thy servants are twelve brethren, the sons of one man in the land of Canaan; and, behold, the youngest is this day with our father, and one is not. And Joseph said unto them, That is it that I spake unto you, saying, Ye are spies: hereby ye shall be proved: by the life of Pharaoh ye shall not go forth hence, except your youngest brother come hither. Send one of you, and let him fetch your brother, and ye shall be kept in prison, that your words may be proved, whether there be any truth in you: or else by the life of Pharaoh surely ye are spies. And he put them all together into ward three days. And Joseph said unto them the third day, This do, and live; for I fear God: if ye be true men, let one of your brethren be bound in the house of your prison: go ye, carry corn for the famine of your houses: but bring your youngest brother unto me; so shall your words be verified, and ye shall not die. And they did so.

And they said one to another, We are verily guilty concerning our brother, in that we saw the anguish of his soul, when he besought us, and we would not hear; therefore is this distress come upon us. And Reuben answered them, saying, Spake I not unto you, saying, Do not sin against the child; and ye would not hear? therefore, behold, also his 
blood is required. And they knew not that Joseph understood them; for he spake unto them by an interpreter. And he turned himself about from them, and wept; and returned to them again, and communed with them, and took from them Simeon, and bound him before their eyes.

Then Joseph commanded to fill their sacks with corn, and to restore every man's money into his sack, and to give them provision for the way: and thus did he unto them. And they laded their asses with the corn, and departed thence. And as one of them opened his sack to give his ass provender in the inn, he espied his money; for, behold, it was in his sack's mouth. And he said unto his brethren, My money is restored; and, lo, it is even in my sack: and their heart failed them, and they were afraid, saying one to another, What is this that God hath done unto us?

And they came unto Jacob their father unto the land of Canaan, and told him all that befell unto them; saying, The man, who is the lord of the land, spake roughly to us, and took us for spies of the country. And we said unto him, We are true men; we are no spies: we be twelve brethren, sons of our father; one is not, and the youngest is this day with our father in the land of Canaan. And the man, the lord of the country, said unto us, Hereby shall I know that ye are true men; leave one of your brethren here with me, and take food for the famine of your households, and be gone: and bring your youngest brother unto me: then shall I know that ye are no spies, but that ye are true men: so will I deliver you your brother, 
and ye shall tràffick in the land. And it came to pass as they emptied their sacks, that, behold, every man's bundle of money was in his sack: and when both they and their father saw the bundles of money, they were afraid. And Jacob their father said unto them, Me have ye bereaved of my children: Joseph is not, and Simeon is not, and ye will take Benjamin away: all these things are against me. And Reuben spake unto his father, saying, Slay my two sons, if I bring him not to thee: deliver him into my hand, and I will bring him to thee again. And he said, My son shall not go down with you; for his brother is dead, and he is left alone: if mischief befall him by the way in the which ye go, then shall ye bring down my gray hairs with sorrow to the grave.

And the famine was sore in the land. And it came to pass, when they had eaten up the corn which they had brought out of Egypt, their father said unto them, Go again, buy us a little food. And Judah spake unto him, saying, The man did solemnly protest unto us, saying, Ye shall not see my face, except your brother be with you. If thou wilt send our brother with us, we will go down and buy thee food: but if thou wilt not send him, we will not go down: for the man said unto us, Ye shall not see my face, except your brother be with you. And Israel said, Wherefore dealt ye so ill with me, as to tell the man whether ye had yet a brother? And they said, The man asked us straitly of our state, and of our kindred, saying, Is your father yet alive? have ye another brother? and we told him according to the tenor of these words: could we certainly know that he would say, Bring your brother 
down? And Judah said unto Israel his father, Send the lad with me, and we will arise and go; that we may live, and not die, both we, and thou, and also our little ones. I will be surety for him; of my hand shalt thou require him: if I bring him not unto thee, and set him before thee, then let me bear the blame for ever: for except we had lingered, surely now we had returned this second time. And their father Israel said unto them, If it must be so now, do this; take of the best fruits in the land in your vessels, and carry down the man a present, a little balm, and a little honey, spices, and myrrh, nuts, and almonds: and take double money in your hand; and the money that was brought again in the mouth of your sacks, carry it again in your hand; peradventure it was an oversight: take also your brother, and arise, go again unto the man: and God Almighty give you mercy before the man, that he may send away your other brother, and Benjamin. If I be bereaved of my children, I am bereaved.

And the men took that present, and they took double money in their hand, and Benjamin; and rose up, and went down to Egypt, and stood before Joseph. And when Joseph saw Benjamin with them, he said to the ruler of his house, Bring these men home, and slay, and make ready; for these men shall dine with me at noon. And the man did as Joseph bade; and the man brought the men into Joseph's house. And the men were afraid, because they ware brought into Joseph's house; and they said, Because of the money that was returned in our sacks at the first time are we brought in; that he may seek occasion against us, and fall upon us, and 
take us for bondmen, and our asses. And they came near to the steward of Joseph's house, and they communed with him at the door of the house, and said, $\mathrm{O}$ sir, we came indeed down at the first time to buy food: and it came to pass, when we came to the inn, that we opened our sacks, and, behold, every man's money was in the mouth of his sack, our money in full weight: and we have brought it again in our hand. And other money have we brought down in our hands to buy food: we cannot tell who put our money in our sacks. And he said, Peace be to you, fear not: your God, and the God of your father, hath given you treasure in your sacks: I had your money. And he brought Simeon out unto them. And the man brought the men into Joseph's house, and gave them water, and they washed their feet; and he gave their asses provender. And they made ready the present against Joseph came at noon: for they heard that they should eat bread there.

And when Joseph came home, they brought him the present which was in their hand into the house, and bowed themselves to him to the earth. And he asked them of their welfare, and said, Is your father well, the old man of whom ye spake? Is he yet alive? And they answered, Thy servant our father is in good health, he is yet alive. And they bowed down their heads, and made obeisance. And he lifted up his eyes, and saw his brother Benjamin, his mother's son, and said, Is this your younger brother, of whom ye spake unto me? And he said, God be gracious unto thee, my son. And Joseph made haste; for his bowels dicl yearn upon his 
brother: and he sought where to weep; and he entered into his chamber, and wept there. And he washed his face, and went out, and refrained himself, and said, Set on bread. And they set on for him by himself, and for them by themselves, and for the Egyptians, which did eat with him, by themselves: because the Egyptians might not eat bread with the Hebrews; for that is an abomination unto the Egyptians. And they sat before him, the firstborn according to his birthright, and the youngest according to his youth: and the men marvelled one at another. And he took and sent messes unto them from before him: but Benjamin's mess was five times so much as any of theirs. And they drank, and were merry with him.

And he commanded the steward of his house, saying, Fill the men's sacks with food, as much as they can carry, and put every man's money in his sack's mouth. And put my cup, the silver cup, in the sack's mouth of the youngest, and his corn money. And he did according to the word that Joseph had spoken. As soon as the morning was light, the men were sent away, they and their asses. And when they were gone out of the city, and not yet far off, Joseph said unto his steward, Up, follow after the men; and when thou dost overtake them, say unto them, Wherefore have ye rewarded evil for good? Is not this it in which my lord drinketh, and whereby indeed he divineth? ye have done evil in so doing. And he overtook them, and he spake unto them these same words. And they said unto him, Wherefore saith my lord these words? God forbid that thy servants should do 
according to this thing: behold, the money, which we found in our sacks' mouths, we brought again unto thee out of the land of Canaan: how then should we steal out of thy lord's house silver or gold? With whomsoever of thy servants it be found, both let him die, and we also will be my lord's bondmen. And he said, Now also let it be according unto your words : he with whom it is found shall be my servant; and ye shall be blameless. Then they speedily took down every man his sack to the ground, and opened every man his sack. And he searched, and began at the eldest, and left at the youngest: and the cup was found in Benjamin's sack. Then they rent their clothes, and laded every man his ass, and returned to the city.

And Judah and his brethren came to Joseph's house ; for he was yet there: and they fell before him on the ground. And Joseph said unto them, What deed is this that ye have done? wot ye not that such a man as I can certainly divine? And Judah said, What shall we say unto my lord? what shall we speak? or how shall we clear ourselves? God hath found out the iniquity of thy servants: behold, we are my lord's servants, both we, and he also with whom the cup is found. And he said, God forbid that I should do so: but the man in whose hand the cup is found, he shall be my servant; and as for you, get you up in peace unto your father.

Then Juclah came near unto him, and said, Oh my lord, let thy servant, I pray thee, speak a word in my lord's ears, and let not thine anger burn against thy servant: for thou art even as Pharaoh. My lord asked his servants, saying, 
Have ye a father, or a brother? And we said unto my lord, We have a father, an old man, and a child of his old age, a little one; and his brother is dead, and he alone is left of his mother, and his father loveth him. And thou saidst unto thy servants, Bring him down unto me, that I may set mine eyes upon him. And we said unto my lord, The lad cannot leave his father; for if he should leave his father, his father would die. And thou saidst unto thy servants, Except your youngest brother come down with you, ye shall see my face no more. And it came to pass when we came up unto thy servant my father, we told him the words of my lord. And our father said, Go again, and buy us a little food. And we said, We cannot go down: if our youngest brother be with us, then will we go down: for we may not see the man's face, except our youngest brother be with us. And thy servant my father said unto us, Ye know that my wife bare me two sons: and the one went out from me, and I said, Surely he is torn in pieces; and I saw him not since: and if ye take this also from me, and mischief befall him, ye shall bring down my gray hairs with sorrow to the grave. Now therefore when I come to thy servant my father, and the lad be not with us; seeing that his life is bound up in the lad's life; it shall come to pass, when he seeth that the lad is not with us, that he will die: and thy servants shall bring lown the gray hairs of thy servant our father with sorrow to the grave. For thy servant became surety for the lad unto my father, saying, If I bring him not unto thee, then I shall bear the blame to my father for 
ever. Now therefore, I pray thee, let thy servant abide instead of the lad a bondman to my lord; and let the lad go up with his brethren. For how shall I go up to my father, and the lad be not with me? lest peradventure I see the evil that shall come on my father.

Then Joseph could not refrain himself before all them that stood by him; and he cried, Cause every man to go out from me. And there stood no man with him, while Joseph made himself known unto his brethren. And he wept aloud: and the Egyptians and the house of Pharaoh heard. And Joseph said unto his brethren, I am Joseph; doth my father yet live? And his brethren could not answer him; for they were troubled at his presence. And Joseph said unto his brethren, Come near to me, I pray you. And they came near. And he said, I am Joseph your brother, whom ye sold into Egypt. Now therefore be not grieved, nor angry with yourselves, that ye sold me hither: for God did send me before you to preserve life. For these two years hath the famine been in the land: and yet there are five years, in the which there shall neither be earing nor harvest. And God sent me before you to preserve you a posterity in the earth, and to save your lives by a great deliverance. So now it was not you that sent me hither, but God: and he hath made me a father to Pharaoh, and lord of all his house, and a ruler throughout all the land of Egypt. Haste ye, and go up to my father, and say unto him, Thus saith thy son Joseph, God hath made me lord of all Egypt: come down unto me, tarry not: and thou shalt dwell in the land of Goshen, and thou shalt 
be near unto me, thou, and thy children, and thy children's children, and thy flocks, and thy herds, and all that thou hast: and there will I nourish thee; for yet there are five years of famine; lest thou, and thy household, and all that thou hast, come to poverty. And, behold, your eyes see, and the eyes of my brother Benjamin, that it is my mouth that speaketh unto you. And ye shall tell my father of all my glory in Egypt, and of all that ye have seen; and ye shall haste and bring down my father hither. And he fell upon his brother Benjamin's neck, and wept; and Benjamin wept upon his neck. Moreover he kissed all his brethren and wept upon them: and after that his brethren talked with him.

And the fame thereof was heard in Pharaoh's house, saying, Joseph's brethren are come: and it pleased Pharaoh well, and his servants. And Pharaoh said unto Joseph, Say unto thy brethren, This do ye; lade your beasts, and go, get you unto the land of Canaan; and take your father and your households, and come unto me: and I will give you the good of the land of Egypt, and ye shall eat the fat of the land. Now thou art commanded, this do ye; take you wagons out of the land of Egypt for your little ones, and for your wives, and bring your father, and come. Also regard not your stuff; for the good of all the land of Egypt is yours. And the children of Israel did so: and Joseph gave them wagons, according to the commandment of Pharaoh, and gave them provision for the way. To all of them he gave each man changes of raiment; but to Benjamin he gave three hundred pieces of 
silver, and five changes of rainent. And to his father he sent after this manner; ten asses laden with the good things of Egypt, and ten she asses laden with corn and bread and meat for his father by the way. So he sent his brethren away, and they departed: and he said unto them, See that ye fall not out by the way.

And they went up out of Egypt, and came into the land of Canaan unto Jacob their father, and told him, saying, Joseph is yet alive, and he is governor over all the land of Egypt. And Jacob's heart fainted, for he believed them not. And they told him all the words of Joseph, which he had said unto them: and when he saw the wagons which Joseph had sent to carry him, the spirit of Jacob their father revived: and Israel said, It is enough; Joseph my son is yet alive: I will go and see him before I die.

And Israel took his journey with all that he had, and came to Beer-sheba, and offered sacrifices unto the God of his father Isaac. And God spake unto Israel in the visions of the night, and said, Jacob, Jacob. And he said, Here am I. And he said, I am God, the God of thy father: fear not to go down into Egypt; for I will there make of thee a great nation: I will go down with thee into Egypt; and I will also surely bring thee up again: and Joseph shall put his hand upon thine eyes. And Jacob rose up from Beer-sheba: and the sons of Israel carried Jacob their father, and their little ones, and their wives, in the wagons which Pharaoh had sent to carry him. And they took their cattle, and their goods, which they had gotten in the land 
of Canaan, and came into Egypt, Jacob, and all his seed with him: his sons, and his sons' sons with him, his daughters, and his sons' daughters, and all his seed brought he with him into Egypt.

And he sent Judah before him unto Joseph, to direct his face unto Goshen; and they came into the land of Goshen. And Joseph made ready his chariot, and went up to meet Israel his father, to Goshen, and presented himself unto him; and he fell on his neck, and wept on his neck a good while. And Israel said unto Joseph, Now let me die, since I have seen thy face, because thou art yet alive. And Joseph said unto his brethren, and unto his father's house, I will go up, and shew Pharaoh, and say unto him, My brethren, and my father's house, which were in the land of Canaan, are come unto me; and the men are shepherds, for their trade hath been to feed cattle; and they have brought their flocks, and their herds, and all that they have. And it shall come to pass, when Pharaoh shall call you, and shall say, What is your occupation? that ye shall say, Thy servants' trade hath been about cattle from our youth even until now, both we, and also our fathers: that ye may dwell in the land of Goshen; for every shepherd is an abomination unto the Egyptians.

Then Joseph came and told Pharaoh, and said, My father and my brethren, and their flocks, and their herds, and all that they have, are come out of the land of Canaan; and, behold, they are in the land of Goshen. And he took some of his brethren, even five men, and presented them unto Pharaoh. 
And Pharaoh said unto his brethren, What is your occupation? And they said unto Pharaoh, Thy servants are shepherds, both we, and also our fathers. They said moreover unto Pharaoh, For to sojourn in the land are we come; for thy servants have no pasture for their flocks; for the famine is sore in the land of Canaan: now therefore, we pray thee, let thy servants dwell in the land of Goshen. And Pharaoh spake unto Joseph, saying, Thy father and thy brethren are come unto thee: the land of Egypt is before thee; in the best of the land make thy father and brethren to dwell; in the land of Goshen let them dwell: and if thou knowest any men of activity among them, then make them rulers over my cattle. And Joseph brought in Jacob his father, and set him before Pharaoh: and Jacob blessed Pharaoh. And Pharaoh said unto Jacob, How old art thou? And Jacob said unto Pharaoh, The days of the years of my pilgrimage are an hunlred and thirty years: few and evil have the days of the years of my life been, and have not attained unto the days of the years of the life of my fathers in the days of their pilgrimage. And Jacob blessed Pharaoh, and went out from before Pharaoh. And Joseph placed his father and his brethren, and gave them a possession in the land of Egypt, in the best of the land, in the land of Rameses, as Pharaoh had commanded. And Joseph nourished his father, and his brethren, and all his father's household, with bread, according to their families. 


\section{XII.}

\section{The Deatb of $\mathcal{F} a c o b$ and $\mathcal{F} 0$ sepb.}

Genesis xlvii. 28-xlviii.; xlix. 33-1. 3 ; 1. 15-26.

And Jacob lived in the land of Egypt seventeen years: so the whole age of Jacob was an hundred forty and seven years. And the time drew nigh that Israel must die: and he called his son Joseph, and said unto him, If now I have found grace in thy sight, put, I pray thee, thy hand under my thigh, and deal kindly and truly with me; bury me not, I pray thee, in Egypt: but I will lie with my fathers, and thou shalt carry me out of Egypt, and bury me in their buryingplace. And he said, I will do as thou hast said. And he said, Swear unto me. And he sware unto him. And Israel bowed himself upon the bed's head.

And it came to pass after these things, that one told Joseph, Behold, thy father is sick: and he took with him his two sons, Manasseh and Ephraim. And one told Jacob, and said, Behold, thy son Joseph cometh unto thee: and Israel strengthened himself, and sat upon the bed. And Jacob said unto Joseph, God Almighty appeared unto me at Luz in the land of Canaan, and blessed me, and said unto me, Behold, I will make thee fruitful, and multiply thee, and I will make of thee a multitude of people; and will give this land to thy seed after thee for an everlasting possession. And now thy two sons, Ephraim and Manasseh, which were born unto thee in the land of Egypt before I came unto thee into 
Egypt, are mine; as Reuben and Simeon, they shall be mine. And thy issue, which thou begettest after them, shall be thine, and shall be called after the name of their brethren in their inheritance. And as for me, when I came from Padan, Rachel died by me in the land of Canaan in the way, when yet there was but a little way to come unto Ephrath: and I buried her there in the way of Ephrath; the same is Beth-lehem. And Israel beheld Joseph's sons, and said, Who are these? And Joseph said unto his father, They are my sons, whom God hath given me in this place. And he said, Bring them, I pray thee, unto me, and I will bless them. Now the eyes of Israel were dim for age, so that he could not see. And he brought them near unto him; and he kissed them, and embraced them. And Israel said unto Joseph, I had not thought to see thy face: and, lo, God hath shewed me also thy seed. And Joseph brought them out from between his knees, and he bowed himself with his face to the earth. And Joseph took them both, Ephraim in his right hand toward Israel's left hand, and Manasseh in his left hand toward Israel's right hand, and brought them near unto him. And Israel stretched out his right hand, and laid it upon Ephraim's head, who was the younger, and his left hand upon Manasseh's head, guiding his hands wittingly; for Manasseh was the firstborn.

And he blessed Joseph, and said, God, before whom my fathers Abraham and Isaac did walk, the God which fed me all my life long unto this day, the Angel which redeemed me from all evil, bless the lads; and let my name be named on them, and 
the name of my fathers Abraham and Isaac; and let them grow into a multitude in the midst of the earth. And when Joseph saw that his father laid his right hand upon the head of Ephraim, it displeased him: and he held up his father's hand, to remove it from Ephraim's head unto Manasseh's head. And Joseph said unto his father, Not so, my father: for this is the firstborn; put thy right hand upon his head. And his father refused, and said, I know it, my son, I know it: he also shall become a people, and he also shall be great: but truly his younger brother shall be greater than he, and his seed shall become a multitude of nations. And he blessed them that day, saying, In thee shall Israel bless, saying, God make thee as Ephraim and as Manasseh: and he set Ephraim before Manasseh. And Israel said unto Joseph, Behold, I die ; but God shall be with you, and bring you again into the land of your fathers. Moreover I have given to thee one portion above thy brethren, which I took out of the hand of the Amorite with my sword and with my bow.

And when Jacob had made an end of commanding his sons, he gathered up his feet into the bed, and yielded up the ghost, and was gathered unto his people. And Joseph fell upon his father's face, and wept upon him, and kissed him. And Joseph commanded his servants the physicians to embalm his father: and the physicians embalmed Israel. And forty days were fulfilled for him; for so are fulfilled the days of those which are embalmed: and 
the Egyptians mourned for him threescore and ten days.

And when Joseph's brethren saw that their father was dead, they said, Joseph will peradventure hate us, and will certainly requite us all the evil which we did unto him. And they sent a messenger unto Joseph, saying, Thy father did command before he died, saying, So shall ye say unto Joseph, Forgive, I pray thee now, the trespass of thy brethren, and their sin; for they did unto thee evil: and now, we pray thee, forgive the trespass of the servants of the God of thy father. And Joseph wept when they spake unto him. And his brethren also went and fell down before his face: and they said, Behold, we be thy servants. And Joseph said unto them, Fear not: for am I in the place of God? But as for you, ye thought evil against me; but God meant it unto good, to bring to pass, as it is this day, to save much people alive. Now therefore fear ye not: I will nourish you, and your little ones. And he comforted them, and spake kindly unto them.

And Joseph dwelt in Egypt, he, and his father's house: and Joseph lived an hundred and ten years. And Joseph saw Ephraim's children of the third generation: the children also of Machir the son of Manasseh were brought up upon Joseph's knees. And Joseph said unto his brethren, I die: and God will surely visit you, and bring you out of this land unto the land which he sware to Abraham, to Isaac, and to Jacob. And Joseph took an oath of the children of Israel, saying, God will surely visit you, and ye shall carry up my bones from hence. So 
Joseph died, being an hundred and ten years old: and they embalmed him, and he was put in a coffin in Egypt.

\section{XIII.}

\section{Inoses.}

Exodus i. 8-I 4 ; ii.-iv. 23 ; iv. 29-3I.

Now there arose up a new king over Egypt, which knew not Joseph. And he said unto his people, Behold, the people of the children of Israel are more and mightier than we: come on, let us deal wisely with them; lest they multiply, and it come to pass, that, when there falleth out any war, they join also unto our enemies, and fight against us, and so get them up out of the land. Therefore they did set over them taskmasters to afflict them with their burdens. And they built for Pharaoh treasure cities, Pithom and Raamses. But the more they afflicted them, the more they multiplied and grew. And they were grieved because of the children of Israel. And the Egyptians made the children of Israel to serve with rigour: and they made their lives bitter with hard bondage, in morter, and in brick, and in all manner of service in the field: all their service, wherein they made them serve, was with rigour.

And there went a man of the house of Levi, and took to wife a daughter of Levi. And the woman conceived, and bare a son: and when she saw him that he was a goodly child, she hid him three months. And when she could not longer hide him, 
she took for him an ark of bulrushes, and daubed it with slime and with pitch, and put the child therein; and she laid it in the flags by the river's brink. And his sister stood afar off, to wit what would be done to him. And the daughter of Pharaoh came down to wash herself at the river; and her maidens walked along by the river's side; and when she saw the ark among the flags, she sent her maid to fetch it. And when she had opened it, she saw the child: and, behold, the babe wept. And she had compassion on him, and said, This is one of the Hebrews' children. Then said his sister to Pharaoh's daughter, Shall I go and call to thee a nurse of the Hebrew women, that she may nurse the child for thee? And Pharaoh's daughter said to her, Go. And the maid went and called the child's mother. And Pharaoh's daughter said unto her, Take this child away, and nurse it for me, and I will give thee thy wages. And the woman took the child, and nursed it. And the child grew, and she brought him unto Pharaoh's daughter, and he became her son. And she called his name Moses [i.e. "Drawn out"] : and she said, Because I drew him out of the water.

And it came to pass in those days, when Moses was grown, that he went out unto his brethren, and looked on their burdens: and he spied an Egyptian smiting an Hebrew, one of his brethren. And he looked this way and that way, and when he saw that there was no man, he slew the Egyptian, and hid him in the sand. And when he went out the second day, behold, two men of the Hebrews strove together: and he said to him that did the wrong, 
Wherefore smitest thou thy fellow? And he said, Who made thee a prince and a judge over us? intendest thou to kill me, as thou killedst the Egyptian? And Moses feared, and said, Surely this thing is known. Now when Pharaoh heard this thing, he sought to slay Moses. But Moses fled from the face of Pharaoh, and dwelt in the land of Midian: and he sat down by a well. Now the priest of Midian had seven daughters: and they came and drew water, and filled the troughs to water their father's flock. And the shepherds came and drove them away: but Moses stood up and helped them, and watered their flock. And when they came to Renel their father, he said, How is it that ye are come so soon to day? And they said, An Egyptian delivered us out of the hand of the shepherds, and also drew water enough for us, and watered the flock. And he said unto his daughters, And where is he? why is it that ye have left the man? call him, that he may eat bread. And Moses was content to dwell with the man: and he gave Moses Zipporah his daughter. And she bare him a son, and he called his name Gershom [i.e. "A stranger here"]: for he said, I have been a stranger in a strange land.

And it came to pass in process of time, that the king of Egypt died: and the children of Israel sighed by reason of the bondage, and they cried, and their cry came up unto God by reason of the bondage. And God heard their groaning, and God remembered his covenant with Abraham, with Isaac, and with Jacob. And God looked upon the children of Israel, and God had respect unto them.

Now Moses kept the flock of Jethro his father in 
law, the priest of Midian: and he led the flock to the backside of the desert, and came to the mountain of God, even to Horeb. And the angel of the Lord appeared unto him in a flame of fire out of the midst of a bush: and he looked, and, behold, the bush burned with fire, and the bush was not consumed. And Moses said, I will now turn aside, and see this great sight, why the bush is not burnt. And when the Lord saw that he turned aside to see, God called unto him out of the midst of the bush, and said, Moses, Moses. And he said, Here am I. And he said, Draw not nigh hither: put off thy shoes from off thy feet, for the place whereon thou standest is holy ground. Moreover he said, I am the God of thy father, the God of Abraham, the God of Isaac, and the God of Jacob. And Moses hid his face; for he was afraid to look upon God. And the Lord said, I have surely seen the affliction of my people which are in Egypt, and have heard their cry by reason of their taskmasters; for I know their sorrows; and I am come down to deliver them out of the hand of the Egyptians, and to bring them up out of that land unto a good land and a large, unto a land flowing with milk and honey; unto the place of the Canaanites, and the Hittites, and the Amorites, and the Perizzites, and the Hivites, and the Jebusites. Now therefore, behold, the cry of the children of Israel is come unto me: and I have also seen the oppression wherewith the Egyptians oppress them. Come now therefore, and I will send thee unto Pharaoh, that thou mayest bring forth my people the children of Israel out of Egypt. 
And Moses said unto God, Who am I, that I should go unto Pharaoh, and that I should bring forth the children of Israel out of Egypt? And he said, Certainly I will be with thee; and this shall be a token unto thee, that I have sent thee: when thou hast brought forth the people out of Egypt, ye shall serve God upon this mountain. And Moses said unto God, Behold, when I come unto the children of Israel, and shall say unto them, The God of your fathers hath sent me unto you; and they shall say to me, What is his name? what shall I say unto them? And God said unto Moses, I AM THAT I AM: and he said, Thus shalt thou say unto the children of Israel, I AM hath sent me unto you. And God said moreover unto Moses, Thus shalt thou say unto the children of Israel, The Lord God of your fathers, the God of Abraham, the God of Isaac, and the God of Jacob, hath sent me unto you: this is my name for ever, and this is my memorial unto all generations. Go, and gather the elders of Israel together, and say unto them, The Lord God of your fathers, the God of Abraham, of Isaac, and of Jacob, appeared unto me, saying, I have surely visited you, and seen that which is done to you in Egypt: and I have said, I will bring you up out of the affliction of Egypt unto the land of the Canaanites, and the Hittites, and the Amorites, and the Perizzites, and the Hivites, and the Jebusites, unto a land flowing with milk and honey. And they shall hearken to thy voice: and thou shalt come, thou and the elders of Israel, unto the king of Egypt, and ye shall say unto him, The Lord God of the Hebrews hath met with us: and now let us 
go, we beseech thee, three days journey into the wilderness, that we may sacrifice to the Lord our God. And I am sure that the king of Egypt will not let you go, no, not by a mighty hand. And I will stretch out my hand, and smite Egypt with all my wonders which I will do in the midst thereof : and after that he will let you go. And I will give this people favour in the sight of the Egyptians: and it shall come to pass, that, when ye go, ye shall not go empty: but every woman shall borrow of her neighbour, and of her that sojourneth in her house, jewels of silver, and jewels of gold, and raiment: and ye shall put them upon your sons, and upon your daughters; and ye shall spoil the Egyptians.

And Moses answered and said, But, behold, they will not believe me, nor hearken unto my voice: for they will say, The Lord hath not appeared unto thee. And the Lord said unto him, What is that in thine hand? And he said, A rod. And he said, Cast it on the ground. And he cast it on the ground, and it became a serpent; and Moses fled from before it. And the Lord said unto Moses, Put forth thine hand, and take it by the tail. And he put forth his hand, and caught it, and it became a rod in his hand: that they may believe that the Lord God of their fathers, the God of Abraliam, the God of Isaac, and the God of Jacob, hath appeared unto thee. And the Lord said furthermore unto him, Put now thine hand into thy bosom. And he put his hand into his bosom: and when he took it out, behold, his hand was leprous as snow. And he said, Put thine hand into thy bosom again. And he put his hand into his bosom again ; and plucked 
it out of his bosom, and, behold, it was turned again as his other flesh. And it shall come to pass, if they will not believe thee, neither hearken to the voice of the first sign, that they will believe the voice of the latter sign. And it shall come to pass, if they will not believe also these two signs, neither hearken unto thy voice, that thou shalt take of the water of the river, and pour it upon the dry land: and the water which thou takest out of the river shall become blood upon the dry land.

And Moses said unto the Lord, O my Lord, I am not eloquent, neither heretofore, nor since thou hast spoken unto thy servant: but I am slow of speech, and of a slow tongue. And the Lord said unto him, Who hath made man's mouth? or who maketh the dumb, or deaf, or the seeing, or the blind? have not I the Lord? Now therefore go, and I will be with thy mouth, and teach thee what thou shalt say. And he said, O my Lord, send, I pray thee, by the hand of him whom thou wilt send. And the anger of the Lord was kindled against Moses, and he said, Is not Aaron the Levite thy brother? I know that he can speak well. And also, behold, he cometh forth to meet thee: and when he seeth thee, he will be glad in his heart. And thou shalt speak unto him, and put words in his mouth: and I will be with thy mouth, and with his mouth, and will teach you what ye shall do. And he shall be thy spokesman unto the people: and he shall be, even he shall be to thee instead of a mouth, and thou shalt be to him instead of God. And thou shalt take this rod in thine hand, wherewith thou shalt do signs.

And Moses went and returned to Jethro his 
father in law, and said unto him, Let me go, I pray thee, and return unto my brethren which are in Egypt, and see whether they be yet alive. And Jethro said to Moses, Go in peace. And the Lord said unto Moses in Midian, Go, return into Egypt: for all the men are dead which sought thy life. And Moses took his wife and his sons, and set them upon an ass, and he returned to the land of Egypt: and Moses took the rod of God in his hand. And the Lord said unto Moses, When thou goest to return into Egypt, see that thou do all those wonders before Pharaoh, which I have put in thine hand: but I will harden his heart, that he shall not let the people go. And thou shalt say unto Pharaoh, Thus saith the Lord, Israel is my son, even my firstborn: and I say unto thee, Let my son go, that he may serve me: and if thou refuse to let him go, behold, I will slay thy son, even thy firstborn.

And Moses and Aaron went and gathered together all the elders of the children of Israel: and Aaron spake all the words which the Lord had spoken unto Moses, and did the signs in the sight of the people. And the people believed: and when they heard that the Lord had visited the children of Israel, and that he had looked upon their affliction, then they bowed their heads and worshipped. 


\section{XIV.}

\section{The Oppression of the $\|$ israelites.}

\section{Exodus v.-vi. 13.}

And afterward Moses and Aaron went in, and told Pharaoh, Thus saith the Lord God of Israel, Let my people go, that they may hold a feast unto me in the wilderness. And Pharaoh said, Who is the Lord, that I should obey his voice to let Israel go? I know not the Lord, neither will I let Israel go. And they said, The God of the Hebrews hath met with us: let us go, we pray thee, three days' journey into the desert, and sacrifice unto the Lord our God; lest he fall upon us with pestilence, or with the sword. And the king of Egypt said unto them, Wherefore do ye, Moses and Aaron, let [i.e. " hinder"] the people from their works? get you unto your burdens. And Pharaoh said, Behold, the people of the land now are many, and ye make them rest from their burdens. And Pharaoh commanded the same day the taskmasters of the people, and their officers, saying, Ye shall no more give the people straw to make brick, as heretofore: let them go and gather straw for themselves. And the tale of the bricks, which they did make heretofore, ye shall lay upon them; ye shall not diminish ought thereof: for they be idle; therefore they cry, saying, Let us go and sacrifice to our God. Let there more work be laid upon the men, that they may labour therein; and let them not regard vain words.

And the taskmasters of the people went out, and 
their officers, and they spake to the people, saying, Thus saith Pharaoh, I will not give you straw. Go ye, get you straw where ye can find it: yet not ought of your work shall be diminished. So the people were scattered abroad throughout all the land of Egypt to gather stubble instead of straw. And the taskmasters hasted them, saying, Fulfil your works, your daily tasks, as when there was straw. And the officers of the children of Israel, which Pharaoh's taskmasters had set over them, were beaten, and demanded, Wherefore have ye not fulfilled your task in making brick both yesterday and to day, as heretofore? Then the officers of the children of Israel came and cried unto Pharaoh, saying, Wherefore dealest thou thus with thy servants? There is no straw given unto thy servants, and they say to us, Make brick: and, behold, thy servants are beaten; but the fault is in thine own people. But he said, Ye are idle, ye are idle: therefore ye say, Let us go and do sacrifice to the Lord. Go therefore now, and work; for there shall no straw be given you, yet shall ye deliver the tale of bricks.

And the officers of the children of Israel did see that they were in evil case, after it was said, Ye shall not minish ought from your bricks of your daily task. And they met Moses and Aaron, who stood in the way, as they came forth from Pharaoh: and they said unto them, The Lord look upon you, and judge; because ye have made our savour to be abhorred in the eyes of Pharaoh, and in the eyes of his servants, to put a sword in their hand to slay us. And Moses returned unto the Lord, and said, Lord, wherefore hast thou so evil entreated this people? 
why is it that thou hast sent me? For since I came to Pharaoh to speak in thy name, he hath done evil to this people; neither hast thou delivered thy people at all.

Then the Lord said unto Moses, Now shalt thou see what I will do to Pharaoh: for with a strong hand shall he let them go, and with a strong hand shall he drive them out of his land. And God spake unto Moses, and said unto him, I am the Lord: and I appeared unto Abraham, unto Isaac, and unto Jacob, by the name of God Almighty; but by my name JEHOVAH was I not known to them. And I have also established my covenant with them, to give them the land of Canaan, the land of their pilgrimage, wherein they were strangers. And I have also heard the groaning of the children of Israel, whom the Egyptians keep in bondage; and I have remembered my covenant. Wherefore say unto the children of Israel, I am the Lord, and I will bring you out from under the burdens of the Egyptians, and I will rid you out of their bondage, and I will redeem you with a stretched out arm, and with great judgments: and I will take you to me for a people, and I will be to you a God: and ye shall know that I am the Lord your God, which bringeth you out from under the burdens of the Egyptians. And I will bring you in unto the land, concerning the which I did swear to give it to Abraham, to Isaac, and to Jacob; and I will give it you for an heritage: I am the Lord.

And Moses spake so unto the children of Israel: but they hearkened not unto Moses for anguish of spirit, and for cruel bondage. And the Lord spake 
unto Moses, saying, Go in, speak unto Pharaoh king of Egypt, that he let the children of Israel go out of his land. And Moses spake before the Lord, saying, Behold, the children of Israel have not hearkened unto me; how then shall Pharaoh hear me, who am of uncircumcised lips? And the Lord spake unto Moses and unto Aaron, and gave them a charge unto the children of Israel, and unto Pharaoh king of Egypt, to bring the children of Israel out of the land of Egypt.

\section{XV.}

\section{The Ten plagues.}

Exodus vi. 28-xii. 4I.

AND it came to pass on the day when the Lord spake unto Moses in the land of Egypt, that the Lord spake unto Moses, saying, I am the Lord: speak thou unto Pharaoh, king of Egypt, all that I say unto thee. And Moses said before the Lord, Behold, I am of uncircumcised lips, and how shall Pharaoh hearken unto me? And the Lord said unto Moses, See, I have made thee a god to Pharaoh: and Aaron thy brother shall be thy prophet. Thou shalt speak all that I command thee: and Aaron thy brother shall speak unto Pharaoh, that he send the children of Israel out of his land. And I will harden Pharaoh's heart, and multiply my signs and my wonders in the land of Egypt. But Pharaoh shall not hearken unto you, that I may lay my hand upon Egypt, and bring forth mine armies, 
and my people the children of Israel, out of the land of Egypt by great judgments. And the Egyptians shall know that I am the Lord, when I stretch forth mine hand upon Egypt, and bring out the children of Israel from among them. And Moses and Aaron did as the Lord commanded them, so did they. And Moses was fourscore years old, and Aaron fourscore and three years old, when they spake unto Pharaoh. And the Lord spake unto Moses and unto Aaron, saying, when Pharaoh shall speak unto you, saying, Shew a miracle for you: then thou shalt say unto Aaron, Take thy rod, and cast it before Pharaoh, and it shall become a serpent.

And Moses and Aaron went in unto Pharaoh, and they did so as the Lord had commanded: and Aaron cast down his rod before Pharaoh, and before his servants, and it became a serpent. Then Pharaoh also called the wise men and the sorcerers : now the magicians of Egypt, they also did in like manner with their enchantments. For they cast down every man his rod, and they became serpents : but Aaron's rod swallowed up their rods. And he hardened Pharaoh's heart, that he hearkened not unto them; as the Lord had said.

And the Lord said unto Moses, Pharaoh's heart is hardened, he refuseth to let the people go. Get thee unto Pharaoh in the morning; lo, he goeth out unto the water; and thou shalt stand by the river's brink against he come; and the rod which was turned to a serpent shalt thou take in thine hand. And thou shalt say unto him, The Lord God of the Hebrews hath sent me unto thee, saying, Let my people go, that they may serve me in the wilderness : 
and, behold, hitherto thou wouldest not hear. Thus saith the Lord, In this thou shalt know that I am the Lord: behold, I will smite with the rod that is in mine hand upon the waters which are in the river, and they shall be turned to blood. And the fish that is in the river shall die, and the river shall stink; and the Egyptians shall loathe to drink of the water of the river. And the Lord spake unto Moses, Say unto Aaron, Take thy rod, and stretch out thine hand upon the waters of Egypt, upon their streams, upon their rivers, and upon their ponds, and upon all their pools of water, that they may become blood; and that there may be blood throughout all the land of Egypt, both in vessels of wood, and in vessels of stone.

And Moses and Aaron did so, as the Lord commanded; and he lifted up the rod, and smote the waters that were in the river, in the sight of Pharaoh, and in the sight of his servants; and all the waters that were in the river were turned to blood. And the fish that was in the river died; and the river stank, and the Egyptians could not drink of the water of the river; and there was blood throughout all the land of Egypt. And the magicians of Egypt did so with their enchantments: and Pharaoh's heart was hardened, neither did he hearken unto them; as the Lord had said. And Pharaoh turned and went into his house, neither did he set his heart to this also. And all the Egyptians digged round about the river for water to drink; for they could not drink of the water of the river. And seven days were fulfilled, after that the Lord had smitten the river. 
And the Lord spake unto Moses, Go unto Pharaoh, and say unto him, Thus saith the Lord, Let my people go, that they may serve me. And if thou refuse to let them go, behold, I will smite all thy borders with frogs: and the river shall bring forth frogs abundantly, which shall go up and come into thine house, and into thy bedchamber, and upon thy bed, and into the house of thy servants, and upon thy people, and into thine ovens, and into thy kneadingtroughs: and the frogs shall come up both on thee, and upon thy people, and upon all thy servants. And the Lord spake unto Moses, Say unto Aaron, Stretch forth thine hand with thy rod over the streams, over the rivers, and over the ponds, and cause frogs to come up upon the land of Egypt. And Aaron stretched out his hand over the waters of Egypt; and the frogs came up, and covered the land of Egypt. And the magicians did so with their enchantments, and brought up frogs upon the land of Egypt.

Then Pharaoh called for Moses and Aaron, and said, Intreat the Lord, that he may take away the frogs from me, and from my people; and I will let the people go, that they may do sacrifice unto the Lord. And Moses said unto Pharaoh, Glory over me: when shall I intreat for thee, and for thy servants, and for thy people, to destroy the frogs from thee and thy houses, that they may remain in the river only? And he said, To morrow. And he said, Be it according to thy word: that thou mayest know that there is none like unto the Lord our God. And the frogs shall depart from thee, and from thy houses, and from thy servants, and from thy people; 
they shall remain in the river only. And Moses and Aaron went out from Pharaoh: and Moses cried unto the Lord because of the frogs which he had brought against Pharaoh. And the Lord did according to the word of Moses; and the frogs died out of the houses, out of the villages, and out of the fields. And they gathered them together upon heaps: and the land stank. But when Pharaoh saw that there was respite, he hardened his heart, and hearkened not unto them; as the Lord had said.

And the Lord said unto Moses, Say unto Aaron, Stretch out thy rod, and smite the dust of the land, that it may become lice throughout all the land of Egypt. And they did so; for Aaron stretched out his hand with his rod, and smote the dust of the earth, and it became lice in man, and in beast; all the dust of the land became lice throughout all the land of Egypt. And the magicians did so with their enchantments to bring forth lice, but they could not: so there were lice upon man, and upon beast. Then the magicians said unto Pharaoh, This is the finger of God: and Pharaoh's heart was hardened, and he hearkened not unto them; as the Lord had said.

And the Lord said unto Moses, Rise up early in the morning, and stand before Pharaoh; lo, he cometh forth to the water; and say unto him, Thus saith the Lord, Let my people go, that they may serve me. Else, if thou wilt not let my people go, behold, I will send swarms of flies upon thee, and upon thy servants, and upon thy people, and into thy houses: and the houses of the Egyptians shall be full of swarms of flies, and also the ground whereon they are. And I will sever in that day the land 
of Goshen, in which my people dwell, that no swarms of flies shall be there; to the end thou mayest know that I am the Lord in the midst of the earth. And I will put a division between my people and thy people: to morrow shall this sign be. And the Lord did so; and there came a grievous swarm of flies into the house of Pharaoh, and into his servants' houses, and into all the land of Egypt: the land was corrupted by reason of the swarm of flies. And Pharaoh called for Moses and for Aaron, and said, Go ye, sacrifice to your God in the land. And Moses said, It is not meet so to do; for we shall sacrifice the abomination of the Egyptians to the Lord our God: lo, shall we sacrifice the abomination of the Egyptians before their eyes, and will they not stone us? We will go three days' journey into the wilderness, and sacrifice to the Lord our God, as he shall command us. And Pharaoh said, I will let you go, that ye may sacrifice to the Lord your God in the wilderness; only ye shall not go very far away: intreat for me. And Moses said, Behold, I go out from thee, and I will intreat the Lord that the swarms of flies may depart from Pharaoh, from his servants, and from his people, to morrow : but let not Pharaoh deal deceitfully any more in not letting the people go to sacrifice to the Lord. And Moses went out from Pharaoh, and intreated the Lord. And the Lord did according to the word of Moses; and he removed the swarms of flies from Pharaoh, from his servants, and from his people; there remained not one. And Pharaoh hardened his heart at this time also, neither would he let the people go. 
Then the Lord said unto Moses, Go in unto Pharaoh, and tell him, Thus saith the Lord God of the Hebrews, Let my people go, that they may serve me. For if thou refuse to let them go, and wilt hold them still, behold, the hand of the Lord is upon thy cattle which is in the field, upon the horses, upon the asses, upon the camels, upon the oxen, and upon the sheep: there shall be a very grievous murrain. And the Lord shall sever between the cattle of Israel and the cattle of Egypt: and there shall nothing die of all that is the children's of Israel. And the Lord appointed a set time, saying, To morrow the Lord shall do this thing in the land. And the Lord did that thing on the morrow, and all the cattle of Egypt died: but of the cattle of the children of Israel died not one. And Pharaoh sent, and, behold, there was not one of the cattle of the Israelites dead. And the heart of Pharaoh was hardened, and he did not let the people go.

And the Lord said unto Moses and unto Aaron, Take to you handfuls of ashes of the furnace, and let Moses sprinkle it toward the heaven in the sight of Pharaoh. And it shall become small dust in all the land of Egypt, and shall be a boil breaking forth with blains upon man, and upon beast, throughout all the land of Egypt. And they took ashes of the furnace, and stood before Pharaoh; and Moses sprinkled it up toward heaven; and it became a boil breaking forth with blains upon man, and upon beast. And the magicians could not stand before Moses because of the boils; for the boil was upon the magicians, and upon all the Egyptians. And the Lord hardened the heart of Pharaoh, and he heark- 
ened not unto them; as the Lord had spoken unto Moses.

And the Lord said unto Moses, Rise up early in the morning, and stand before Pharaoh, and say unto him, Thus saith the Lord God of the Hebrews, Let my people go, that they may serve me. For I will at this time send all my plagues upon thine heart, and upon thy servants, and upon thy people; that thou mayest know that there is none like me in all the earth. For now I will stretch out my hand, that I may smite thee and thy people with pestilence; and thou shalt be cut off from the earth. And in very deed for this cause have I raised thee up, for to shew in thee my power; and that my name may be declared throughout all the earth. As yet exaltest thou thyself against my people, that thou wilt not let them go? Behold, to morrow about this time I will cause it to rain a very grievous hail, such as hath not been in Egypt since the foundation thereof even until now. Send therefore now, and gather thy cattle, and all that thou hast in the field; for upon every man and beast which shall be found in the field, and shall not be brought home, the hail shall come down upon them, and they shall die. He that feared the word of the Lord among the servants of Pharaoh made his servants and his cattle flee into the houses: and he that regarded not the word of the Lord left his servants and his cattle in the field.

And the Lord said unto Moses, Stretch forth thine hand toward heaven, that there may be hail in all the land of Egypt, upon man, and upon beast, and upon every herb of the field, throughout the land of 
Egypt. And Moses stretched forth his rod toward heaven: and the Lord sent thunder and hail, and the fire ran along upon the ground; and the Lord rained hail upon the land of Egypt. So there was hail, and fire mingled with the hail, very grievous, such as there was none like it in all the land of Egypt since it became a nation. And the hail smote throughout all the land of Egypt all that was in the field, both man and beast; and the hail smote every herb of the field, and brake every tree of the field. Only in the land of Goshen, where the children of Israel were, was there no hail.

And Pharaoh sent, and called for Moses and Aaron, and said unto them, I have sinned this time: the Lord is righteous, and I and my people are wicked. Intreat the Lord (for it is enougli) that there be no more mighty thunderings and hail; and I will let you go, and ye shall stay no longer. And Moses said unto him, As soon as I am gone out of the city, I will spread abroad my hands unto the Lord; and the thunder shall cease, neither shall there be any more hail ; that thou mayest know how that the earth is the Lord's. But as for thee and thy servants, I know that ye will not yet fear the Lord God. And the flax and the barley was smitten: for the barley was in the ear, and the flax was bolled. But the wheat and the rie were not smitten: for they were not grown up. And Moses went out of the city from Pharaoh, and spread abroad his hands unto the Lord: and the thunders and hail ceased, and the rain was not poured upon the earth. And when Pharaoh saw that the rain and the hail and the thunders were ceased, he sinned yet more, and liard- 
ened his heart, he and his servants. And the heart of Pharaoh was hardened, neither would he let the children of Israel go; as the Lord had spoken by Moses.

And the Lord said unto Moses, Go in unto Pharaoh: for $I$ have hardened his heart, and the heart of his servants, that I might shew these my signs before him: and that thou mayest tell in the ears of thy son, and of thy son's son, what things I have wrought in Egypt, and my signs which I have done among them; that ye may know how that I am the Lord. And Moses and Aaron came in, unto Pharaoh, and said unto him, Thus saith the Lord God of the Hebrews, How long will thou refuse to humble thyself before me? let my people go, that they may serve me. Else, if thou refuse to let my people go, behold, to morrow will I bring the locusts into thy coast: and they shall cover the face of the earth, that one cannot be able to see the earth: and they shall eat the residue of that which is escaped, which remaineth unto you from the hail, and shall eat every tree which groweth for you out of the field: and they shall fill thy houses, and the houses of all thy servants, and the houses of all the Egyptians; which neither thy fathers, nor thy fathers' fathers have seen, since the day that they were upon the earth unto this day. And he turned himself, and went out from Pharaoh. And Pharaoh's servants said unto him, How long shall this man be a snare unto us? let the men go, that they may serve the Lord their God: knowest thou not yet that Egypt is destroyed? And Moses and Aaron were brought again unto Pharaoh: and he said unto them, Go, 
serve the Lord your God: but who are they that shall go? And Moses said, We will go with our young and with our old, with our sons and with our daughters, with our flocks and with our herds will we go; for we must hold a feast unto the Lord. And he said unto them, Let the Lord be so with you, as I will let you go, and your little ones: look to it; for evil is before you. Not so: go now ye that are men, and serve the Lord; for that ye did desire. And they were driven out from Pharaoh's presence.

And the Lord said unto Moses, Stretch out thine hand over the land of Egypt for the locusts, that they may come up upon the land of Egypt, and eat every herb of the land, even all that the hail hath left. And Moses stretched forth his rod over the land of Egypt, and the Lord brought an east wind upon the land all that day, and all that night; and when it was morning, the east wind brought the locusts. And the locusts went up over all the land of Egypt, and rested in all the coasts of Egypt: very grievous were they; before them there were no such locusts as they, neither after them shall be such. For they covered the face of the whole earth, so that the land was darkened; and they did eat every herb of the land, and all the fruit of the trees which the hail had left: and there remained not any green thing in the trees, or in the herbs of the field, through all the land of Egypt. Then Pharaoh called for Moses and Aaron in haste; and he said, I have sinned against the Lord your God, and against you. Now therefore forgive, I pray thee, my sin only this once, and intreat the Lord your God, that he may take away from me this death only. And he went 
out from Pharaoh, and intreated the Lord. And the Lord turned a mighty strong west wind, which took away the locusts, and cast them into the Red sea; there remained not one locust in all the coasts of Egypt. But the Lord hardened Pharaoh's heart, so that he would not let the children of Israel go.

And the Lord said unto Moses, Stretch out thine hand toward heaven, that there may be darkness over the land of Egypt, even darkness which may be felt. And Moses stretched forth his hand toward heaven; and there was a thick darkness in all the land of Egypt three days: they saw not one another, neither rose any from his place for three days: but all the children of Israel had light in their dwellings. And Pharaoh called unto Moses, and said, Go ye, serve the Lord ; only let your flocks and your herds be stayed: let your little ones also go with you. And Moses said, Thou must give us also sacrifices and burnt offerings, that we may sacrifice unto the Lord our God. Our cattle also shall go with us; there shall not an hoof be left behind; for thereof must we take to serve the Lord our God; and we know not with what we must serve the Lord, until we come thither. But the Lord hardened Pharaoh's heart, and he would not let them go. And Pharaoh said unto him, Get thee from me, take heed to thyself, see my face no more; for in that clay thou seest my face thou shalt die. And Moses said, Thou hast spoken well, I will see thy face again no more.

And the Lord said unto Moses, Yet will I bring one plague more upon Pharaoh, and upon Egypt; afterwards he will let you go hence: when he shall 
let you go, he shall surely thrust you out hence altogether. Speak now in the ears of the people, and let every man borrow of his neighbour, and every woman of her neighbour, jewels of silver, and - jewels of gold. And the Lord gave the people favour in the sight of the Egyptians. Moreover the man Moses was very great in the land of Egypt, in the sight of Pharaoh's servants, and in the sight of the people. And Moses said, Thus saith the Lord, About midnight will I go out into the midst of Egypt: and all the firstborn in the land of Egypt shall die, from the firstborn of Pharaoh that sitteth upon his throne, even unto the firstborn of the maidservant that is behind the mill; and all the firstborn of beasts. And there shall be a great cry throughout all the land of Egypt, such as there was none like it, nor shall be like it any more. But against any of the children of Israel shall not a dog move his tongue, against man or beast: that ye may know how that the Lord doth put a difference between the Egyptians and Israel. And all these thy servants shall come down unto me, and bow down themselves unto me, saying, Get thee out, and all the people that follow thee: and after that I will go out. And he went out from Pharaoh in a great anger. And the Lord said unto Moses, Pharaoh shall not hearken unto you; that my wonders may be multiplied in the land of Egypt. And Moses and Aaron did all these wonders before Pharaoh: and the Lord hardened Pharaoh's heart, so that he would not let the children of Israel go out of his land.

And the Lord spake unto Moses and Aaron in 
the land of Egypt, saying, This month shall be unto you the beginning of months: it shall be the first month of the year to you. Speak ye unto all the congregation of Israel, saying, In the tenth day of this month they shall take to them every man a lamb, according to the house of their fathers, a lamb for an house: and if the household be too little for the lamb, let him and his neighbour next unto his house take it according to the number of the souls; every man according to his eating shall make your count for the lamb. Your lamb shall be without blemish, a male of the first year: ye shall take it out from the sheep, or from the goats: and ye shall keep it up until the fourteenth day of the same month: and the whole assembly of the congregation of Israel shall kill it in the evening. And they shall take of the blood, and strike it on the two side posts and on the upper door post of the houses, wherein they shall eat it. And they shall eat the flesh in that night, roast with fire, and unleavened bread; and with bitter herbs they shall eat it. Eat not of it raw, nor sodden at all with water, but roast with fire; his head with his legs, and with the purtenance thereof. And ye shall let nothing of it remain until the morning; and that which remaineth of it until the morning ye shall burn with fire. And thus shall ye eat it; with your loins girded, your shoes on your feet, and your staff in your hand; and ye shall eat it in haste: it is the Lord's passover. For I will pass through the land of Egypt this night, and will smite all the firstborn in the land of Egypt, both man and beast; and against all the gods of Egypt I will execute judg- 
ment: I am the Lord. And the blood shall be to you for a token upon the houses where ye are: and when I see the blood, I will pass over you, and the plague shall not be upon you to destroy you, when I smite the land of Egypt. And this day shall be unto you for a memorial; and ye shall keep it a feast to the Lord throughout your generations; ye shall keep it a feast by an ordinance for ever. Seven days shall ye eat unleavened bread; even the first day ye shall put away leaven out of your houses: for whosoever eateth leavened bread from the first day until the seventh day, that soul shall be cut off from Israel. And in the first day there shall be an holy convocation, and in the seventh day there shall be an holy convocation to you; no manner of work shall be done in them, save that which every man must eat, that only may be done of you. And ye shall observe the feast of unleavened bread; for in this selfsame day have I brought your armies out of the land of Egypt: therefore shall ye observe this day in your generations by an ordinance for ever. In the first month, on the fourteenth day of the month at even, ye shall eat unleavened bread, until the one and twentieth day of the month at even. Seven days shall there be no leaven found in your houses: for whosoever eateth that which is leavened, even that soul shall be cut off from the congregation of Israel, whether he be a stranger, or born in the land. Ye shall eat nothing leavened; in all your habitations shall ye eat unleavened bread.

Then Moses called for all the elders of Israel, and said unto them, Draw out and take you a 
lamb according to your families, and kill the passover. And ye shall take a bunch of hyssop, and dip it in the blood that is in the bason, and strike the lintel and the two side posts with the blood that is in the bason; and none of you shall go out at the door of his house until the morning. For the Lord will pass through to smite the Egyptians; and when he seeth the blood upon the lintel, and on the two side posts, the Lord will pass over the door, and will not suffer the destroyer to come in unto your houses to smite you. And ye shall observe this thing for an ordinance to thee and to thy sons for ever. And it shall come to pass, when ye be come to the land which the Lord will give you, according as he hath promised, that ye shall keep this service. And it shall come to pass, when your children shall say unto you, What mean ye by this service? that ye shall say, It is the sacrifice of the Lord's passover, who passed over the houses of the children of Israel in Egypt, when he smote the Egyptians, and delivered our houses. And the people bowed the head and worshipped. And the children of Israel went away, and did as the Lord had commanded Moses and Aaron, so did they.

And it came to pass, that at midnight the Lord smote all the firstborn in the land of Egypt, from the firstborn of Pharaol that sat on his throne unto the firstborn of the captive that was in the dungeon; and all the firstborn of cattle. And Pharaoh rose up in the night, he, and all his servants, and all the Egyptians; and there was a great cry in Egypt ; for there was not a house where there was not one dead. And he called for Moses and 
Aaron by night, and said, Rise up, and get you forth from aniong my people, both ye and the children of Israel; and go, serve the Lord, as ye have said. Also take your flocks and your herds, as ye have said, and be gone; and bless me also. And the Egyptians were urgent upon the people, that they might send them out of the land in haste; for they said, We be all dead men.

And the people took their dough before it was leavened, their kneadingtroughs being bound up in their clothes upon their shoulders. And the children of Israel did according to the word of Moses; and they borrowed of the Egyptians jewels of silver, and jewels of gold, and raiment: and the Lord gave the people favour in the sight of the Egyptians, so that they lent unto them such things as they required. And they spoiled the Egyptians. And the children of Israel journeyed from Rameses to Succoth, about six hundred thousand on foot that were men, beside children. And a mixed multitude went up also with them; and flocks, and herds, even very much cattle. And they baked unleavened cakes of the dough which they brought forth out of Egypt, for it was not leavened; because they were thrust out of Egypt, and could not tarry, neither had they prepared for themselves any victual.

Now the sojourning of the children of Israel, who dwelt in Egypt, was four hundred and thirty years. And it came to pass at the end of the four hundred and thirty years, even the selfsame day it came to pass, that all the hosts of the Lord went out from the land of Egypt. 


\section{XVI.}

\section{The Dassage of the Red sea.}

Exodus xiii. 17-xiv.

And it came to pass, when Pharaoh had let the people go, that God led them not through the way of the land of the Philistines, although that was near; for God said, Lest peradventure the people repent when they see war, and they return to Egypt: but God led the people about, through the way of the wilderness of the Red sea: and the children of Israel went up harnessed out of the land of Egypt. And Moses took the bones of Joseph with him: for he had straitly sworn the children of Israel, saying, God will surely visit you; and ye shall carry up my bones away hence with you. And they took their journey from Succoth, and encamped in Etham, in the edge of the wilderness. And the Lord went before them by day in a pillar of a cloud, to lead them the way; and by night in a pillar of fire, to give them light; to go by day and night: he took not away the pillar of the cloud by day, nor the pillar of fire by night, from before the people.

And the Lord spake unto Moses, saying, Speak unto the children of Israel, that they turn and encamp before Pi-hahiroth, between Migdol and the sea, over against Baal-zephon: before it shall ye encamp by the sea. For Pharaoh will say of the children of Israel, They are entangled in the land, the wilderness hath shut them in. And I will harden Pharaoh's heart, that he shall follow after 
them; and I will be honoured upon Pharaoh, and upon all his host; that the Egyptians may know that I am the Lord. And they did so.

And it was told the king of Egypt that the people fled: and the heart of Pharaoh and of his servants was turned against the people, and they said, Why have we done this, that we have let Israel go from serving us? And he made ready his chariot, and took his people with him: and he took six hundred chosen chariots, and all the chariots of Egypt, and captains over every one of them. And the Lord hardened the heart of Pharaoh king of Egypt, and he pursued after the children of Israel: and the children of Israel went out with an high hand. But the Egyptians pursued after them, all the horses and chariots of Pharaoh, and his horsemen, and his army, and overtook them encamping by the sea, beside Pi-hahiroth, before Baal-zephon.

And when Pharaoh drew nigh, the children of Israel lifted up their eyes, and, behold, the Egyptians marched after them; and they were sore afraid: and the children of Israel cried out unto the Lord. And they said unto Moses, Because there were no graves in Egypt, hast thou taken us away to die in the wilderness? wherefore hast thou dealt thus with us, to carry us forth out of Egypt? Is not this the word that we did tell thee in Egypt, saying, Let us alone, that we may serve the Egyptians? For it had been better for us to serve the Egyptians, than that we should die in the wilderness. And Moses said unto the people, Fear ye not, stand still, and see the salvation of the Lord, which he will shew to you to clay: for the Egyptians whom 
ye have seen to day, ye shall see them again no more for ever. The Lord shall fight for you, and ye shall hold your peace. And the Lord said unto Moses, Wherefore criest thou unto me? speak unto the children of Israel, that they go forward: but lift thou up thy rod, and stretch out thine hand over the sea, and divide it: and the children of Israel shall go on dry ground through the midst of the sea. And I, behold, I will harden the hearts of the Egyptians, and they shall follow them: and I will get me honour upon Pharaoh, and upon all his host, upon his chariots, and upon his horsemen. And the Egyptians shall know that I am the Lord, when I have gotten me honour upon Pharaoh, upon his chariots, and upon his horsemen.

And the angel of God, which went before the camp of Israel, removed and went behind them; and the pillar of the cloud went from before their face, and stood behind them: and it came between the camp of the Egyptians and the camp of Israel; and it was a cloud and darkness to them, but it gave light by night to these: so that the one came not near the other all the night. And Moses stretched out his hand over the sea; and the Lord caused the sea to go back by a strong east wind all that night, and made the sea dry land, and the waters were divided. And the children of Israel went into the midst of the sea upon the dry ground: and the waters were a wall unto them on their right hand, and on their left. And the Egyptians pursued, and went in after them to the midst of the sea, even all Pharaoh's horses, his chariots, and his horsemen. And it came to pass, that in the morning watch the Lord 
looked unto the host of the Egyptians through the pillar of fire and of the cloud, and troubled the host of the Egyptians, and took off their chariot wheels, that they drave them heavily: so that the Egyptians said, Let us flee from the face of Israel; for the Lord fighteth for them against the Egyptians.

And the Lord said unto Moses, Stretch out thine hand over the sea, that the waters may come again upon the Egyptians, upon their chariots, and upon their horsemen. And Moses stretched forth his hand over the sea, and the sea returned to his strength when the morning appeared; and the Egyptians fled against it; and the Lord overthrew the Egyptians in the midst of the sea. And the waters returned, and covered the chariots, and the horsemen, and all the host of Pharaoh that came into the sea after them; there remained not so much as one of them. But the children of Israel walked upon dry land in the midst of the sea; and the waters were a wall unto them on their right hand, and on their left. Thus the Lord saved Israel that day out of the hand of the Egyptians; and Israel saw the Egyptians dead upon the sea shore. And Israel saw that great work which the Lord did upon the Egyptians: and the people feared the Lord, and believed the Lord, and his servant Moses. 


\section{XVII.}

\section{Tbe Ten Conmanoments.}

Exodus xix.-xx. 21.

In the third month, when the children of Israel were gone forth out of the land of Egypt, the same day came they into the wilderness of Sinai. For they were departed from Rephidim, and were come to the desert of Sinai, and had pitched in the wilderness; and there Israel camped before the mount. And Moses went up unto God, and the Lord called unto him out of the mountain, saying, Thus shalt thou say to the house of Jacob, and tell the children of Israel; ye have seen what I did unto the Egyptians, and how I bare you on eagles' wings, and brought you unto myself. Now therefore, if ye will obey my voice indeed, and keep my covenant, then ye shall be a peculiar treasure unto me above all people: for all the earth is mine: and ye shall be unto me a kingdom of priests, and an holy nation. These are the words which thou shalt speak unta the children of Israel.

And Moses came and called for the elders of the people, and laid before their faces all these words which the Lord commanded him. And all the people answered together, and said, All that the Lord hath spoken we will do. And Moses returned the words of the people unto the Lord. And the Lord said unto Moses, Lo, I come unto thee in a thick cloud, that the people may hear when I speak with thee, and believe thee for ever. And Moses 
told the words of the people unto the Lord. And the Lord said unto Moses, Go unto the people, and sanctify them to day and to morrow, and let them wash their clothes, and be ready against the third day: for the third day the Lord will come down in the sight of all the people upon mount Sinai. And thou shalt set bounds unto the people round about, saying, Take heed to yourselves, that ye go not up into the mount, or touch the border of it: whosoever toucheth the mount shall be surely put to death: there shall not an hand touch it, but he shall surely be stoned, or shot through; whether it be beast or man, it shall not live: when the trumpet soundeth long, they shall come up to the mount. And Moses went down from the mount unto the people, and sanctified the people; and they washed their clothes. And he said unto the people, Be ready against the third day: come not at your wives.

And it came to pass on the third day in the morning, that there were thunders and lightnings, and a thick cloud upon the mount, and the voice of the trumpet exceeding loud; so that all the people that was in the camp trembled. And Moses brought forth the people out of the camp to meet with God; and they stood at the nether part of the mount. And mount Sinai was altogether on a smoke, because the Lord descended upon it in fire: and the smoke thereof ascended as the smoke of a furnace, and the whole mount quaked greatly. And when the voice of the trumpet sounded long, and waxed louder and louder, Moses spake, and God answered him by a voice. And the Lord came down upon mount Sinai, on the top of 
the mount: and the Lord called Moses up to the top of the mount; and Moses went up. And the Lord said unto Moses, Go down, charge the people, lest they break through unto the Lord to gaze, and many of them perish. And let the priests also, which come near to the Lord, sanctify themselves, lest the Lord break forth upon them. And Moses said unto the Lord, The people cannot come up to mount Sinai: for thou chargedst us, saying, Set bounds about the mount, and sanctify it. And the Lord said unto him, Away, get thee down, and thou shalt come up, thou, and Aaron with thee: but let not the priests and the people break through to come up unto the Lord, lest he break forth upon them. So Moses went down unto the people, and spake unto them.

And God spake all these words, saying, I am the Lord thy God, which have brought thee out of the land of Egypt, out of the house of bondage.

Thou shalt have no other gods before me.

Thou shalt not make unto thee any graven image, or any likeness of any thing that is in heaven above, or that is in the earth beneath, or that is in the water under the earth: thou shalt not bow down thyself to them, nor serve them: for I the Lord thy God am a jealous God, visiting the iniquity of the fathers upon the children unto the third and fourth generation of them that hate me; and shewing mercy unto thousands of them that love me, and keep my commandments.

Thou shalt not take the name of the Lord thy God in vain ; for the Lord will not hold him guiltless that taketh his name in vain. 
Remember the sabbath day, to keep it holy. Six days shalt thou labour, and do all thy work: but the seventh day is the sabbath of the Lord thy God: in it thou shalt not do any work, thou, nor thy son, nor thy daughter, thy manservant, nor thy maidservant, nor thy cattle, nor thy stranger that is within thy gates: for in six days the Lord made heaven and earth, the sea, and all that in them is, and rested the seventh day: wherefore the Lord blessed the sabbath day, and hallowed it.

Honour thy father and thy mother: that thy days may be long upon the land which the Lord thy God giveth thee.

Thou shalt not kill.

Thou shalt not commit adultery.

Thou shalt not steal.

Thou shalt not bear false witness against thy neighbour.

Thou shalt not covet thy neighbour's house, thou shalt not covet thy neighbour's wife, nor his manservant, nor his maidservant, nor his ox, nor his ass, nor any thing that is thy neighbour's.

And all the people saw the thunderings, and the lightnings, and the noise of the trumpet, and the mountain smoking: and when the people saw it, they removed, and stood afar off. And they said unto Moses, Speak thou with us, and we will hear: but let not God speak with us, lest we die. And Moses said unto the people, Fear not: for God is come to prove you, and that his fear may be before your faces, that ye sin not. And the people stood afar off, and Moses drew near unto the thick darkness where God was. 


\section{XVIII.}

\section{The Golden calf.}

Exodus xxxii.

And when the people saw that Moses delayed to come down out of the mount, the people gathered themselves together unto Aaron, and said unto him, Up, make us gods, which shall go before us; for as for this Moses, the man that brought us up out of the land of Egypt, we wot not what is become of him. And Aaron said unto them, Break off the golden earrings, which are in the ears of your wives, of your sons, and of your daughters, and bring them unto me. And all the people brake off the golden earrings which were in their ears, and brought them unto Aaron. And he received them at their hand, and fashioned it with a graving tool, after he had made it a molten calf: and they said, These be thy gods, O Israel, which brought thee up out of the land of Egypt. And when Aaron saw it, he built an altar before it; and Aaron made proclamation, and said, To morrow is a feast to the Lord. And they rose up early on the morrow, and offered burnt offerings, and brought peace offerings; and the people sat down to eat and to drink, and rose up to play.

And the Lord said unto Moses, Go, get thee down; for thy people, which thou broughtest out of the land of Egypt, have corrupted themselves: they have turned asicle quickly out of the way which I commanded them: they have made them a molten 
calf, and have worshipped it, and have sacrificed thereunto, and said, These be thy gods, O Israel, which have brought thee up out of the land of Egypt. And the Lord said unto Moses, I have seen this people, and, behold, it is a stiffnecked people: now therefore let me alone, that my wrath may wax hot against them, and that I may consume them: and I will make of thee a great nation. And Moses besought the Lord his God, and said, Lord, why doth thy wrath wax hot against thy people, which thou hast brought forth out of the land of Egypt with great power, and with a mighty hand? Wherefore should the Egyptians speak, and say, For mischief did he bring them out, to slay them in the mountains, and to consume them from the face of the earth? Turn from thy fierce wrath, and repent of this evil against thy people. Remember Abraham, Isaac, and Israel, thy servants, to whom thou swarest by thine own self, and saidst unto them, I will multiply your seed as the stars of heaven, and all this land that I have spoken of will I give unto your seed, and they shall inherit it for ever. And the Lord repented of the evil which he thought to do unto his people.

And Moses turned, and went down from the mount, and the two tables of the testimony were in his hand: the tables were written on both their sides; on the one side and on the other were they written. And the tables were the work of God, and the writing was the writing of God, graven upon the tables. And when Joshua heard the noise of the people as they shouted, he said unto Moses, There is a noise of war in the camp. And he said, 
It is not the voice of them that shout for mastery, neither is it the voice of them that cry for being overcome: but the noise of them that sing do I hear.

And it came to pass, as soon as he came nigh unto the camp, that he saw the calf, and the dancing: and Moses' anger waxed hot, and he cast the tables out of his hands, and brake them beneath the mount. And he took the calf which they had made, and burnt it in the fire, and ground it to powder, and strawed it upon the water, and made the children of Israel drink of it. And Moses said unto Aaron, What did this people unto thee, that thou hast brought so great a sin upon them? And Aaron said, Let not the anger of my lord wax hot: thou knowest the people, that they are set on mischief. For they said unto me, Make us gods, which shall go before us: for as for this Moses, the man that brought us up out of the land of Egypt, we wot not what is become of him. And I said unto them, Whosoever hath any gold, let them break it off. So they gave it me: then I cast it into the fire, and there came out this calf. And when Moses saw that the people were naked; (for Aaron had made them naked unto their shame among their enemies:) then Moses stood in the gate of the camp, and said, Who is on the Lord's side? let him come unto me. And all the sons of Levi gathered themselves together unto him. And he said unto them, Thus saith the Lord God of Israel, Put every man his sword by his side, and go in and out from gate to gate throughout the camp, and slay every man his brother, and every man his companion, and every man his neighbour. And the children of Levi did 
according to the word of Moses: and there fell of the people that day about three thousand men. For Moses had said, Consecrate yourselves to day to the Lord, even every man upon his son, and upon his brother; that he may bestow upon you a blessing this day.

And it came to pass on the morrow, that Moses said unto the people, Ye have sinned a great sin: and now I will go up unto the Lord; peradventure I shall make an atonement for your sin. And Moses returned unto the Lord, and said, $\mathrm{Oh}$, this people have sinned a great sin, and have made them gods of gold. Yet now, if thou wilt forgive their sin-; and if not, blot me, I pray thee, out of thy book which thou hast written. And the Lord said unto Moses, Whosoever hath sinned against me, him will I blot out of my book. Therefore now go, lead the people unto the place of which I have spoken unto thee: behold, mine Angel shall go before thee: nevertheless in the day when I visit I will visit their sin upon them. And the Lord plagued the people, because they made the calf, which Aaron made.

\section{XIX. \\ Tbe Deatb of Iisoses.}

Deuteronomy xxxiv.

And Moses went up from the plains of Moab unto the mountain of Nebo, to the top of Pisgah, that is over against Jericho. And the Lord shewed him all 
the land of Gilead, unto Dan, and all Naphtali, and the land of Ephraim, and Manasseh, and all the land of Judah, unto the utmost sea, and the south, and the plain of the valley of Jericho, the city of palm trees, unto Zoar. And the Lord said unto him, This is the land which I sware unto Abraham, unto Isaac, and unto Jacob, saying, I will give it unto thy seed: I have caused thee to see it with thine eyes, but thou shalt not go over thither.

So Moses the servant of the Lord died there in the land of Moab, according to the word of the Lord. And he buried him in a valley in the land of Moab, over against Beth-peor: but no man knoweth of his sepulchre unto this day. And Moses was an hundred and twenty years old when he died: his eye was not dim, nor his natural force abated. And the children of Israel wept for Moses in the plains of Moab thirty days: so the days of weeping and mourning for Moses were ended.

And Joshua the son of Nun was full of the spirit of wisdom; for Moses had laid his hands upon him: and the children of Israel hearkened unto him, and did as the Lord commanded Moses. And there arose not a prophet since in Israel like unto Moses, whom the Lord knew face to face, in all the signs and the wonders, which the Lord sent him to do in the land of Egypt to Pharaoh, and to all his servants, and to all his land, and in all that mighty hand, and in all the great terror which Moses shewed in the sight of all Israel. 


\section{$\mathrm{XX}$.}

\section{TRabab and the Ipies.}

Joshua ii.

AND Joshua the son of Nun sent out of Shittim two men to spy secretly, saying, Go view the land, even Jericho. And they went, and came into an harlot's house, named Rahab, and lodged there. And it was told the king of Jericho, saying, Behold, there came men in hither to night of the children of Israel to search out the country. And the king of Jericho sent unto Rahab, saying, Bring forth the men that are come to thee, which are entered into thine house: for they be come to search out all the country. And the woman took the two men, and hid them, and said thus, There came men unto me, but I wist not whence they were: and it came to pass about the time of shutting the gate, when it was dark, that the men went out: whither the men went I wot not: pursue after them quickly; for ye shall overtake them. But she had brought them up to the roof of the house, and hid them with the stalks of flax, which she had laid in order upon the roof. And the men pursued after them the way to Jordan unto the fords: and as soon as they which pursued after them were gone out, they shut the gate.

And before they were laid down, she came up unto them upon the roof; and she said unto the men, I know that the Lord hath given you the land, and that your terror is fallen upon us, and that all 
the inhabitants of the land faint because of you. For we have heard how the Lord dried up the water of the Red sea for you, when ye came out of Egypt; and what ye did unto the two kings of the Amorites, that were on the other side Jordan, Sihon and Og, whom ye utterly destroyed. And as soon as we had heard these things, our hearts did melt, neither did there remain any more courage in any man, because of you: for the Lord your God, he is God in heaven above, and in earth beneath. Now therefore, I pray you, swear unto me by the Lord, since I have shewed you kindness, that ye will also shew kindness unto my father's house, and give me a true token: and that ye will save alive my father, and my mother, and my brethren, and my sisters, and all that they have, and deliver our lives from death. And the men answered her, Our life for your's, if ye utter not this our business. And it shall be, when the Lord hath given us the land, that we will deal kindly and truly with thee. Then she let them down by a cord through the window: for her house was upon the town wall, and she dwelt upon the wall. And she said unto them, Get you to the mountain, lest the pursuers meet you; and hide yourselves there three days, until the pursuers be returned: and afterward may ye go your way. And the men said unto her, We will be blameless of this thine oath which thou hast made us swear. Behold, when we come into the land, thou shalt bind this line of scarlet thread in the window which thou didst let us down by: and thou shalt bring thy father, and thy mother, and thy brethren, and all thy father's household, home unto thee. And it 
shall be, that whosoever shall go out of the doors of thy house into the street, his blood shall be upon his head, and we will be guiltless: and whosoever shall be with thee in the house, his blood shall be on our head, if any hand be upon him. And if thou utter this our business, then we will be quit of thine oath which thou hast made us to swear. And she said, According unto your words, so be it. And she sent them away, and they leparted: and she bound the scarlet line in the window. And they went, and came unto the mountain, and abode there three days, until the pursuers were returned: and the pursuers sought them throughout all the way, but found them not.

So the two men returned, and descended from the mountain, and passed over, and came to Joshua the son of Nun, and told him all things that befell them: and they said unto Joshua, Truly the Lord hath delivered into our hands all the land; for even all the inhabitants of the country do faint because of us.

\section{XXI.}

\section{Tbe Iiege of $\mathcal{F}$ erícbo.}

\section{Joshua vi.}

Now Jericho was straitly shut up because of the children of Israel : none went out, and none came in. And the Lord said unto Joshua, See, I have given into thine hand Jericho, and the king thereof, and the mighty men of valour. And ye shall compass the city, all ye men of war, and go round about the 
city once. Thus shalt thou do six days. And seven priests shall bear before the ark seven trumpets of rams' horns: and the seventh day ye shall compass the city seven times, and the priests shall blow with the trumpets. And it shall come to pass, that when they make a long blast with the ram's horn, and when ye hear the sound of the trumpet, all the people shall shout with a great shout; and the wall of the city shall fall down flat, and the people shall ascend up every man straight before him.

And Joshua the son of Nun called the priests, and said unto them, Take up the ark of the covenant, and let seven priests bear seven trumpets of rams' horns before the ark of the Lord. And he said unto the people, Pass on, and compass the city, and let him that is armed pass on before the ark of the Lord. And it came to pass, when Joshua had spoken unto the people, that the seven priests bearing the seven trumpets of rams' horns passed on before the Lord, and blew with the trumpets: and the ark of the covenant of the Lord followed them. And the armed men went before the priests that blew with the trumpets, and the rereward came after the ark, the priests going on, and blowing with the trumpets. And Joshua had commanded the people, saying, Ye shall not shout, nor make any noise with your voice, neither shall any word proceed out of your mouth, until the day I bid you shout; then shall ye shout. So the ark of the Lord compassed the city, going about it once: and they came into the camp, and lodged in the camp.

And Joshua rose early in the morning, and the 
priests took up the ark of the Lord. And seven priests bearing seven trumpets of rams' horns before the ark of the Lord went on continually, and blew with the trumpets: and the armed men went before them; but the rereward came after the ark of the Lord, the priests going on, and blowing with the trumpets. And the second day they compassed the city once, and returned into the camp: so they did six days.

And it came to pass on the seventh day, that they rose early about the dawning of the day, and compassed the city after the same manner seven times: only on that day they compassed the city seven times. And it came to pass at the seventh time, when the priests blew with the trumpets, Joshua said unto the people, Shout; for the Lord hath given you the city. And the city shall be accursed, even it, and all that are therein, to the Lord: only Rahab the harlot shall live, she and all that are with her in the house, because she hid the messengers that we sent. And ye, in any wise keep yourselves from the accursed thing, lest ye make yourselves accursed, when ye take of the accursed thing, and make the camp of Israel a curse, and trouble it. But all the silver, and gold, and vessels of brass and iron, are consecrated unto the Lord: they shall come into the treasury of the Lord.

So the people shouted when the priests blew with the trumpets: and it came to pass, when the people heard the sound of the trumpet, and the people shouted with a great shout, that the wall fell down flat, so that the people went up into the city, every man straight before him, and they took the city. 
And they utterly destroyed all that was in the city, both man and woman, young and old, and ox, and sheep, and ass, with the edge of the sword. But Joshua had said unto the two men that had spied out the country, Go into the harlot's house, and bring out thence the woman, and all that she hath, as ye sware unto her. And the young men that were spies went in, and brought out Rahab, and her father, and her mother, and her brethren, and all that she had; and they brought out all her kindred, and left them without the camp of Israel. And they burnt the city with fire, and all that was therein: only the silver, and the gold, and the vessels of brass and of iron, they put into the treasury of the house of the Lord. And Joshua saved Rahab the harlot alive, and her father's household, and all that she had; and she dwelleth in Israel even unto this day; because she hid the messengers, which Joshua sent to spy out Jericho.

And Joshua adjured them at that time, saying, Cursed be the man before the Lord, that riseth up and buildeth this city Jericho: he shall lay the foundation thereof in his firstborn, and in his youngest son shall he set up the gates of it. So the Lord was with Joshua; and his fame was noised throughout all the country. 


\section{XXII.}

\section{Fosbua at Gibeon.}

Joshua X. I-I 5 .

Now it came to pass, when Adoni-zedec king of Jerusalem had heard how Joshua had taken Ai, and had utterly destroyed it; as he had done to Jericho and her king, so he had done to $\mathrm{Ai}$ and her king; and how the inhabitants of Gibeon had made peace with Israel, and were among them; that they feared greatly, because Gibeon was a great city, as one of the royal cities, and because it was greater than $\mathrm{Ai}$, and all the men thereof were mighty. Wherefore Adoni-zedec king of Jerusalem sent unto Hoham king of Hebron, and unto Piram king of Jarmuth, and unto Japhia king of Lachish, and unto Debir king of Eglon, saying, Come up unto me, and help me, that we may smite Gibeon: for it hath made peace with Joshua and with the children of Israel. Therefore the five kings of the Amorites, the king of Jerusalem, the king of Hebron, the king of Jarmuth, the king of Lachish, the king of Eglon, gathered themselves together, and went up, they and all their hosts, and encamped before Gibeon, and made war against it.

And the men of Gibeon sent unto Joshua to the camp to Gilgal, saying, Slack not thy hand from thy servants; come up to us quickly, and save us, and help us: for all the kings of the Amorites that dwell in the mountains are gathered together against us. So Joshua ascended from Gilgal, he, and all the 
people of war with him, and all the mighty men of valour. And the Lord said unto Joshua, Fear them not : for I have delivered them into thine hand; there shall not a man of them stand before thee. Joshua therefore came unto them suddenly, and went up from Gilgal all night. And the Lord discomfited them before Israel, and slew them with a great slaughter at Gibeon, and chased them along the way that goeth up to Beth-horon, and smote them to Azekah, and unto Makkedah. And it came to pass, as they fled from before Israel, and were in the going down to Beth-horon, that the Lord cast down great stones from heaven upon them unto Azekah, and they died: they were more which died with hailstones than they whom the children of Israel slew with the sword.

Then spake Joshua to the Lord in the day when the Lord delivered up the Amorites before the children of Israel, and he said in the sight of Israel, Sun, stand thou still upon Gibeon; and thou, Moon, in the valley of Ajalon. And the sun stood still, and the moon stayed, until the people had avenged themselves upon their enemies. Is not this written in the book of Jasher? So the sun stood still in the midst of heaven, and hasted not to go down about a whole day. And there was no day like that before it or after it, that the Lord hearkened unto the voice of a man: for the Lord fought for Israel. And Joshua returned, and all Israel with him, unto the camp to Gilgal. 


\section{XXIII.}

\section{Tbe \$eatb of Fosbua.}

Joshua xxiii.-xxiv. 3 I.

And it came to pass a long time after that the Lord had given rest unto Israel from all their enemies round about, that Joshua waxed old and stricken in age. And Joshua called for all Israel, and for their elders, and for their heads, and for their judges, and for their officers, and said unto them, I am old and stricken in age: and ye have seen all that the Lord your God hath done unto all these nations because of you; for the Lord your God is he that hath fought for you. Behold, I have divided unto you by lot these nations that remain, to be an inheritance for your tribes, from Jordan, with all the nations that I have cut off, even unto the great sea westward. And the Lord your God, he shall expel them from before you, and drive them from out of your sight; and ye shall possess their land, as the Lord your God hath promised unto you. Be ye therefore very courageous to keep and to do all that is written in the book of the law of Moses, that ye turn not aside therefrom to the right hand or to the left; that ye come not among these nations, these that remain among you; neither make mention of the name of their gods, nor cause to swear by them, neither serve them, nor bow yourselves unto them: but cleave unto the Lord your God, as ye have done unto this day. For the Lord hath driven out from before you great nations and 
strong: but as for you, no man hath been able to stand before you unto this day. One man of you thall chase a thousand: for the Lord your God, he it is that fighteth for you, as he hath promised you. Take good heed therefore unto yourselves, that ye love the Lord your God. Else if ye do in any wise go back, and cleave unto the remnant of these nations, even these that remain among you, and shall make marriages with them, and go in unto them, and they to you: know for a certainty that the Lord your God will no more drive out any of these nations from before you; but they shall be snares and traps unto you, and scourges in your sides, and thorns in your eyes, until ye perish from off this good land which the Lord your God hath given you.

And, behold, this day I am going the way of all the earth: and ye know in all your hearts and in all your souls, that not one thing hath failed of all the good things which the Lord your God spake concerning you; all are come to pass unto you, and not one thing hath failed thereof. Therefore it shall come to pass, that as all good things are come upon you, which the Lord your God promised you; so shall the Lord bring upon you all evil things, until he have destroyed you from off this good land which the Lord your God hath given you. When ye have transgressed the covenant of the Lord your God, which he commanded you, and have gone and served other gods, and bowed yourselves to them; then shall the anger of the Lord be kindled against you, and ye shall perish quickly from off the good land which he hath given unto you. 
And Joshua gathered all the tribes of Israel to Shechem, and called for the elders of Israel, and for their heads, and for their judges, and for their officers; and they presented themselves before God. And Joshua said unto all the people, Thus saith the Lord God of Israel, Your fathers dwelt on the other side of the flood in old time, even Terah, the father of Abraham, and the father of Nachor: and they served other gods. And I took your father Abraham from the other side of the flood, and led him throughout all the land of Canaan, and multiplied his seed, and gave him Isaac. And I gave unto Isaac Jacob and Esau; and I gave unto Esau mount Seir, to possess it; but Jacob and his children went down into Egypt. I sent Moses also and Aaron, and I plagued Egypt according to that which I did among them: and afterward I brought you out. And I brought your fathers out of Egypt: and ye came unto the sea; and the Egyptians pursued after your fathers with chariots and horsemen unto the Red sea. And when they cried unto the Lord, he put darkness between you and the Egyptians, and brought the sea upon them, and covered them; and your eyes have seen what I have done in Egypt: and ye dwelt in the wilderness a long season. And I brought you into the land of the Amorites, which dwelt on the other side Jordan; and they fought with you: and I gave them into your hand, that ye might possess their land; and I destroyed them from before you. Then Balak the son of Zippor, king of Moab, arose and warred against Israel, and sent and called Balaam the son of Peor to curse you: but I would not 
hearken unto Balaam; therefore he blessed you still: so I delivered you out of his hand. And ye went over Jordan, and came unto Jericho: and the men of Jericho fought against you, the Amorites, and the Perizzites, and the Canaanites, and the Hittites, and the Girgashites, the Hivites, and the Jebusites; and I delivered them into your hand. And I sent the hornet before you, which drave them out from before you, even the two kings of the Amorites; but not with thy sword, nor with thy bow. And I have given you a land for which ye did not labour, and cities which ye built not, and ye dwell in them; of the vineyards and oliveyards which ye planted not do ye eat.

Now therefore fear the Lord, and serve him in sincerity and in truth: and put away the gods which your fathers served on the other side of the flood, and in Egypt; and serve ye the Lord. And if it seem evil unto you to serve the Lord, choose you this day whom ye will serve; whether the gods which your fathers served that were on the other side of the flood, or the gods of the Amorites, in whose land ye dwell: but as for me and my house, we will serve the Lord. And the people answered and said, God forbid that we should forsake the Lord, to serve other gods; for the Lord our God, he it is that brought us up and our fathers out of the land of Egypt, from the house of bondage, and which did those great signs in our sight, and preserved us in all the way wherein we went, and, among all the people through whom we passed: and the Lord drave out from before us all the people, even the Amorites which dwelt in the land: 
therefore will we also serve the Lord; for he is our God. And Joshua said unto the people, Ye cannot serve the Lord: for he is an holy God; he is a jealous God; he will not forgive your transgressions nor your sins. If ye forsake the Lord, and serve strange gods, then he will turn and do you hurt, and consume you, after that he hath done you good. And the people said unto Joshua, Nay; but we will serve the Lord. And Joshua said unto the people, $\mathrm{Ye}$ are witnesses against yourselves that ye have chosen you the Lord, to serve him. And they said, We are witnesses. Now therefore put away, said he, the strange gods which are among you, and incline your heart unto the Lord God of Israel. And the people said unto Joshua, The Lord our God will we serve, and his voice will we obey. So Joshua made a covenant with the people that day, and set them a statute and an ordinance in Shechem.

And Joshua wrote these words in the book of the law of God, and took a great stone, and set it up there under an oak, that was by the sanctuary of the Lord. And Joshua said unto all the people, Behold, this stone shall be a witness unto us; for it hath heard all the words of the Lord which he spake unto us: it shall be therefore a witness unto you, lest ye deny your God. So Joshua let the people depart, every man unto his inheritance.

And it came to pass after these things, that Joshua the son of Nun, the servant of the Lord, died, being an hundred and ten years old. And they buried him in the border of his inheritance in Timnath-serah, which is in mount Ephraim, on the north side of the hill of Gaash. And Israel served 
the Lord all the days of Joshua, and all the days of the elders that overlived Joshua, and which had known all the works of the Lord, that he had done for Israel.

\section{XXIV.}

\section{Sisera allo Fael.}

Judges iv.

AND the children of Israel again did evil in the sight of the Lord, when Ehud was dead. And the Lord sold them into the hand of Jabin king of Canaan, that reigned in Hazor; the captain of whose host was Sisera, which dwelt in Harosheth of the Gentiles. And the children of Israel cried unto the Lord: for he had nine hundred chariots of iron; and twenty years he mightily oppressed the children of Israel.

And Deborah, a prophetess, the wife of Lapidoth, she judged Israel at that time. And she dwelt under the palm tree of Deborah between Ramah and Beth-el in mount Ephraim: and the children of Israel came up to her for judgment. And she sent and called Barak the son of Abinoam out of Kedesh-naphtali, and said unto him, Hath not the Lord God of Israel commanded, saying, Go and draw toward mount Tabor, and take with thee ten thousand men of the children of Naphtali and of the children of Zebulun? And I will draw unto thee, to the river Kishon Sisera the captain of Jabin's army, with his chariots and his multitude; and I will deliver him into thine hand. And Barak 
said unto her, If thou wilt go with me, then I will go: but if thou wilt not go with me, then I will not go. And she said, I will surely go with thee: notwithstanding the journey that thou takest shall not be for thine honour; for the Lord shall sell Sisera into the hand of a woman. And Deborah arose, and went with Barak to Kedesh.

And Barak called Zebulun and Naphtali to Kedesh; and he went up with ten thousand men at his feet: and Deborah went up with him. Now Heber the Kenite, which was of the children of Hobab the father in law of Moses, had severed himself from the Kenites, and pitched his tent unto the plain of Zaanaim, which is by Kedesh. And they shewed Sisera that Barak the son of Abinoam wàs gone up to mount Tabor. And Sisera gathered together all his chariots, even nine hundred chariots of iron, and all the people that were with him, from Harosheth of the Gentiles unto the river of Kishon. And Deborah said unto Barak, Up; for this is the day in which the Lord hath delivered Sisera into thine hand: is not the Lord gone out before thee? So Barak went down from mount Tabor, and ten thousand men after him. And the Lord discomfited Sisera, and all his chariots, and all his host, with the edge of the sword before Barak; so that Sisera lighted down off his chariot, and fled away on his feet. But Barak pursued after the chariots, and after the host, unto Harosheth of the Gentiles: and all the host of Sisera fell upon the edge of the sword; and there was not a man left.

Howbeit Sisera fled away on his feet to the tent of Jael the wife of Heber the Kenite: for there was 
peace between Jabin the king of Hazor and the house of Heber the Kenite. And Jael went out to meet Sisera, and said unto him, Turn in, my lord, turn in to me; fear not. And when he had turned in unto her into the tent, she covered him with a mantle. And he said unto her, Give me, I pray thee, a little water to drink; for I am thirsty. And she opened a bottle of milk, and gave him drink, and covered him. Again he said unto her, Stand in the door of the tent, and it shall be, when any man doth come and enquire of thee, and say, Is there any man here? that thou shalt say, No. Then Jael Heber's wife took a nail of the tent, and took an hammer in her hand, and went softly unto him, and smote the nail into his temples, and fastened it into the ground: for he was fast asleep and weary. . So he died. And, behold, as Barak pursued Sisera, Jael came out to meet him, and said unto him, Come, and I will shew thee the man whom thou seekest. And when he came into her tent, behold, Sisera lay dead, and the nail was in his temples.

So God subdued on that day Jabin the king of Canaan before the children of Israel. And the hand of the children of Israel prospered, and prevailed against Jabin the king of Canaan, until they had destroyed Jabin king of Canaan. 


\section{XXV. \\ Gioeon's $\mathcal{H}$ rmp.}

Judges vii.

Then Jerubbaal, who is Gideon, and all the people that were with him, rose up early, and pitched beside the well of Harod: so that the host of the Midianites were on the north side of them, by the hill of Moreh, in the valley. And the Lord said unto Gideon, The people that are with thee are too many for me to give the Midianites into their hands, lest Israel vaunt themselves against me, saying, Mine own hand hath saved me. Now therefore go to, proclaim in the ears of the people, saying, Whosoever is fearful and afraid, let him return and depart early from mount Gilead. And there returned of the people twenty and two thousand; and there remained ten thousand. And the Lord said unto Gideon, The people are yet too many; bring them down unto the water, and I will try them for thee there: and it shall be, that of whom I say unto thee, This shall go with thee, the same shall go with thee; and of whomsoever I say unto thee, This shall not go with thee, the same shall not go. So he brought down the people unto the water : and the Lord said unto Gideon, Every one that lappeth of the water with his tongue, as a dog lappeth, him shalt thou set by himself; likewise every one that boweth down upon his knees to drink. And the number of them that lapped, putting their hand to their mouth, were three hun- 
dred men : but all the rest of the people bowed down upon their knees to drink water. And the Lord said unto Gideon, By the three hundred men that lapped will I save you, and deliver the Midianites into thine hand: and let all the other people go every man unto his place. So the people took victuals in their hand, and their trumpets: and he sent all the rest of Israel every man unto his tent, and retained those three hundred men: and the host of Midian was beneath him in the valley.

And it came to pass the same night, that the Lord said unto him, Arise, get thee down unto the host; for I have delivered it into thine hand. But if thou fear to go down, go thou with Phurah thy servant down to the host: and thou shalt hear what they say; and afterward shall thine hands be strengthened to go down unto the host. Then went he down with Phurah his servant unto the outside of the armed men that were in the host. And the Midianites and the Amalekites and all the children of the east lay along in the valley like grasshoppers for multitude; and their camels were without number, as the sand by the sea side for multitude. And when Gideon was come, behold, there was a man that told a dream unto his fellow, and said, Behold, I dreamed a dream, and, lo, a cake of barley bread tumbled into the host of Midian, and came unto a tent, and smote it that it fell, and overturned it, that the tent lay along. And his fellow answered and said, This is nothing else save the sword of Gideon the son of Joash, a man of Israel: for into his hand hath God delivered Midian, and all the host. 
And it was so, when Gideon heard the telling of the dream, and the interpretation thereof, that he worshipped, and returned into the host of Israel, and said, Arise; for the Lord hath delivered into your hand the host of Midian. And he divided the three hundred men into three companies, and he put a trumpet in every man's hand, with empty pitchers, and lamps within the pitchers. And he said unto them, Look on me, and do likewise: and, behold, when I come to the outside of the camp, it shall be that, as I do, so shall ye do. When I blow with a trumpet, I and all that are with me, then blow ye the trumpets also on every side of all the camp, and say, The sword of the Lord, and of Gideon.

So Gideon, and the hundred men that were with him, came unto the outside of the camp in the beginning of the middle watch; and they had but newly set the watch: and they blew the trumpets, and brake the pitchers that were in their hands. And the three companies blew the trumpets, and brake the pitchers, and held the lamps in their left hands, and the trumpets in their right hands to blow withal: and they cried, The sword of the Lord, and of Gideon. And they stood every man in his place round about the camp: and all the host ran, and cried, and fled. And the three hundred blew the trumpets, and the Lord set every man's sword against his fellow, even throughout all the host: and the host fled to Beth-shittah in Zererath, and to the border of Abel-meholah, unto Tabbath. And the men of Israel gathered themselves together out of Naphtali, and out of Asher, 
and out of all Manasseh, and pursued after the Midianites.

And Gideon sent messengers throughout all mount Ephraim, saying, Come down against the Midianites, and take before them the waters unto Beth-barah and Jordan. Then all the men of Ephraim gathered themselves together, and took the waters unto Beth-barah and Jordan. And they took two princes of the Midianites, Oreb and Zeeb; and they slew Oreb upon the rock Oreb, and Zeeb they slew at the winepress of Zeeb, and pursued Midian, and brought the heads of Oreb and Zeeb to Gideon on the other side Jordan.

\section{XXVI.}

\section{Fłbimelecb and Fotbam.}

Judges viii. $33-\mathrm{ix}$.

AND it came to pass, as soon as Gideon was dead, that the children of Israel turned again, and went a whoring after Baalim, and made Baal-berith their god. And the children of Israel remembered not the Lord their God, who had delivered them out of the hands of all their enemies on every side: neither shewed they kindness to the house of Jerubbaal, namely, Gideon, according to all the goodness which he had shewed unto Israel.

And Abimelech the son of Jerubbaal went to Shechem unto his mother's brethren, and communed with them, and with all the family of the house of his mother's father, saying, Speak, I pray you, in 
the ears of all the men of Shechem, Whether is better for you, either that all the sons of Jerubbaal, which are threescore and ten persons, reign over you, or that one reign over you? remember also that I am your bone and your flesh. And his mother's brethren spake of him in the ears of all the men of Shechem all these words: and their hearts inclined to follow Abimelech; for they said, He is our brother. And they gave him threescore and ten pieces of silver out of the house of Baal-berith, wherewith Abimelech hired vain and light persons, which followed him. And he went unto his father's house at Ophrah, and slew his brethren the sons of Jerubbaal, being threescore and ten persons, upon one stone: notwithstanding yet Jotham the youngest son of Jerubbaal was left; for he hid himself. And all the men of Shechem gathered together, and all the house of Millo, and went and made Abimelech king, by the plain of the pillar that was in Shechem.

And when they told it to Jotham, he went and stood in the top of mount Gerizim, and lifted up his voice, and cried, and said unto them, Hearken unto me, ye men of Shechem, that God may hearken unto you. The trees went forth on a time to anoint a king over them; and they said unto the olive tree, Reign thou over us. But the olive tree said unto them, Should I leave my fatness, wherewith by me they honour God and man, and go to be promoted over the trees? And the trees said to the fig tree, Come thou, and reign over us. But the fig tree said unto them, Should I forsake my sweetness, and my good fruit, and go to be promoted over the trees? Then said the trees unto the vine, Come thou, and 
reign over us. And the vine said unto them, Should I leave my wine, which cheereth God and man, and go to be promoted over the trees? Then said all the trees unto the bramble, Come thou, and reign over us. And the bramble said unto the trees, If in truth ye anoint me king over you, then come and put your trust in my shadow: and if not, let fire come out of the bramble, and devour the cedars of Lebanon. Now therefore, if ye have done truly and sincerely, in that ye have made Abimelech king, and if ye have dealt well with Jerubbaal and his house, and have done unto him according to the deserving of his hands; (for my father fought for you, and adventured his life far, and delivered you out of the hand of Midian: and ye are risen up against my father's house this day, and have slain his sons, threescore and ten persons, upon one stone, and have made Abimelech, the son of his maidservant, king over the men of Shechem, because he is your brother;) if ye then have dealt truly and sincerely with Jerubbaal and with his house this day, then rejoice ye in Abimelech, and let him also rejoice in you: but if not, let fire come out from Abimelech, and devour the men of Shechem, and the house of Millo; and let fire come out from the men of Shechem, and from the house of Millo, and devour Abimelech. And Jotham ran away, and fled, and went to Beer, and dwelt there, for fear of Abimelech his brother.

When Abimelech had reigned three years over Israel, then God sent an evil spirit between Abimelech and the men of Shechem; and the men of Shechem dealt treacherously with Abimelech: that 
the cruelty done to the threescore and ten sons of Jerubbaal might come, and their blood be laid upon Abimelech their brother, which slew them; and upon the men of Shechem, which aided him in the killing of his brethren. And the men of Shechem set liers in wait for him in the top of the mountains, and they robbed all that came along that way by them: and it was told Abimelech. And Gaal the son of Ebed came with his brethren, and went over to Shechem: and the men of Shechem put their confidence in him. And they went out into the fields, and gathered their vineyards, and trode the grapes, and made merry, and went into the house of their god, and did eat and drink, and cursed Abimelech. And Gaal the son of Ebed said, Who is Abimelech, and who is Shechem, that we should serve him? is not he the son of Jerubbaal? and Zebul his officer? serve the men of Hamor the father of Shechem: for why should we serve him? And would to God this people were under my hand! then would I remove Abimelech. And he said to Abimelech, Increase thine army, and come out.

And when Zebul the ruler of the city heard the words of Gaal the son of Ebed, his anger was kindled. And he sent messengers unto Abimelech privily, saying, Behold, Gaal the son of Ebed and his brethren be come to Shechem; and, behold, they fortify the city against thee. Now therefore up by night, thou and the people that is with thee, and lie in wait in the field: and it shall be, that in the morning, as soon as the sun is up, thou shalt rise early, and set upon the city: and, behold, when he and the people that is with him come out against 
thee, then mayest thou do to them as thou shalt find occasion.

And Abimelech rose up, and all the people that were with him, by night, and they laid wait against Shechem in four companies. And Gaal the son of Ebed went out, and stood in the entering of the gate of the city: and Abimelech rose up, and the people that were with him, from lying in wait. And when Gaal saw the people, he said to Zebul, Behold, there come people down from the top of the mountains. And Zebul said unto him, Thou seest the shadow of the mountains as if they were men. And Gaal spake again and said, See there come people down by the middle of the land, and another company come along by the plain of Meonenim. Then said Zebul unto him, Where is now thy mouth, wherewith thou saidst, Who is Abimelech, that we should serve him? is not this the people that thou hast despised? go out, I pray now, and fight with them. And Gaal went out before the men of Shechem, and fought with Abimelech. And Abimelech chased him, and he fled before him, and many were overthrown and wounded, even unto the entering of the gate. And Abimelech dwelt at Arumah: and Zebul thrust out Gaal and his brethren, that they should not dwell in Shechem.

And it came to pass on the morrow, that the people went out into the field ; and they told Abimelech. And he took the people, and divided them into three companies, and laid wait in the field, and looked, and, behold, the people were come forth out of the city; and he rose up against them, and smote them. And Abimelech, and the company that was 
with him, rushed forward, and stood in the entering of the gate of the city: and the two other companies ran upon all the people that were in the fields, and slew them. And Abimelech fought against the city all that day; and he took the city, and slew the people that was therein, and beat down the city, and sowed it with salt. And when all the men of the tower of Shechem heard that, they entered into an hold of the house of the god Berith. And it was told Abimelech, that all the men of the tower of Shechem were gathered together. And Abimelech gat him up to mount Zalmon, he and all the people that were with him; and Abimelech took an ax in his hand, and cut down a bough from the trees, and took it, and laid it on his shoulder, and said unto the people that were with him, What ye have seen me do, make haste, and do as I have done. And all the people likewise cut down every man his bough, and followed Abimelech, and put them to the hold, and set the hold on fire upon them; so that all the men of the tower of Shechem died also, about a thousand men and women.

Then went Abimelech to Thebez, and encamped against Thebez, and took it. But there was a strong tower within the city, and thither fled all the men and women, and all they of the city, and shut it to them, and gat them up to the top of the tower. And Abimelech came unto the tower, and fought against it, and went hard unto the door of the tower to burn it with fire. And a certain woman cast a piece of a millstone upon Abimelech's head, and all to brake his skull. Then he called hastily unto the young man his armourbearer, and said 
unto him, Draw thy sword, and slay me, that men say not of me, A woman slew him. And his young man thrust him through, and he died. And when the men of Israel saw that Abimelech was dead, they departed every man unto his place. Thus God rendered the wickedness of Abimelech, which he did unto his father, in slaying his seventy brethren: and all the evil of the men of Shechem did God render upon their heads: and upon them came the curse of Jotham the son of Jerubbaal.

\section{XXVII.}

\section{Jepbtbab's Vow.}

\section{Judges xi. 30-40.}

And Jephthah vowed a vow unto the Lord, and said, If thou shalt without fail deliver the children of Ammon into mine hands, then it shall be, that whatsoever cometh forth of the doors of my house to meet me, when I return in peace from the children of Ammon, shall surely be the Lord's, and I will offer it up for a burnt offering. So Jephthah passed over unto the children of Ammon to fight against them; and the Lord delivered them into his hands. And he smote them from Aroer, even till thou come to Minnith, even twenty cities, and unto the plain of the vineyards, with a very great slaughter. Thus the children of Ammon were subdued before the children of Israel.

And Jephthah came to Mizpeh unto his house, and, behold, his daughter came out to meet him 
with timbrels and with dances: and she was his only child; beside her he had neither son nor daughter. And it came to pass, when he saw her, that he rent his clothes, and said, Alas, my daughter! thou hast brought me very low, and thou art one of them that trouble me: for I have opened my mouth unto the Lord, and I cannot go back. And she said unto him, My father, if thou hast opened thy mouth unto the Lord, do to me according to that which hath proceeded out of thy mouth; forasmuch as the Lord hath taken vengeance for thee of thine enemies, even of the children of Ammon. And she said unto her father, Let this thing be done for me: let me alone two months, that I may go up and down upon the mountains, and bewail my virginity, I and my fellows. And he said, Go. And he sent her away for two months: and she went with her companions, and bewailed her virginity upon the mountains. And it came to pass at the end of two months, that she returned unto her father, who did with her according to his vow which he had vowed: and she knew no man. And it was a custom in Israel, that the daughters of Israel went yearly to lament the daughter of Jephthah the Gileadite four days in a year. 


\section{XXVIII.}

\section{জamson.}

Judges xiii. 24-xvi.

AND the woman [Manoah's wife] bare a son, and called his name Samson: and the child grew, and the Lord blessed him. And the Spirit of the Lord began to move him at times in the camp of Dan between Zorah and Eshtaol.

And Samson went down to Timnath, and saw a woman in Timnath of the daughters of the Philistines. And he came up, and told his father and his mother, and said, I have seen a woman in Timnath of the daughters of the Philistines: now therefore get her for me to wife. Then his father and his mother said unto him, Is there never a woman among the daughters of thy brethren, or among all my people, that thou goest to take a wife of the uncircumcised Philistines? And Samson said unto his father, Get her for me; for she pleaseth me well. But his father and his mother knew not that it was of the Lord, that he sought an occasion against the Philistines: for at that time the Philistines had dominion over Israel.

Then went Samson down, and his father and his mother, to Timnath, and came to the vineyards of Timnath: and, behold, a young lion roared against him. And the Spirit of the Lord came mightily upon him, and he rent him as he would have rent a kid, and he had nothing in his hand: but he told not his father or his mother what he had done. And 
he went down, and talked with the woman; and she pleased Samson well. And after a time he returned to take her, and he turned aside to see the carcase of the lion: and, behold, there was a swarm of bees and honey in the carcase of the lion. And he took thereof in his hands, and went on eating, and came to his father and mother, and he gave them, and they did eat: but he told not them that he had taken the honey out of the carcase of the lion.

So his father went down unto the woman: and Samson made there a feast; for so used the young men to do. And it came to pass, when they saw him, that they brought thirty companions to be with him. And Samson said unto them, I will now put forth a riddle unto you: if ye can certainly declare it me within the seven days of the feast, and find it out, then I will give you thirty sheets and thirty change of garments: but if ye cannot declare it me, then shall ye give me thirty sheets and thirty change of garments. And they said unto him, Put forth thy riddle, that we may hear it. And he said unto them, Out of the eater came forth meat, and out of the strong came forth sweetness. And they could not in three days expound the riddle. And it came to pass on the seventh day, that they said unto Samson's wife, Entice thy husband, that he may declare unto us the riddle, lest we burn thee and thy father's house with fire: have ye called us to take that we have? is it not so? And Samson's wife wept before him, and said, Thou dost but hate me, and lovest me not: thou hast put forth a riddle unto the children of my people, and hast not told it me. And he said unto her, Behold, I have not 
told it my father nor my mother, and shall I tell it thee? And she wept before him the seven days, while their feast lasted: and it came to pass on the seventh day, that he told her, because she lay sore upon him: and she told the riddle to the children of her people. And the men of the city said unto him on the seventh day before the sun went down, What is sweeter than honey? and what is stronger than a lion? And he said unto them, If ye had not plowed with my heifer, ye had not found out my riddle.

And the Spirit of the Lord came upon him, and he went down to Ashkelon, and slew thirty men of them, and took their spoil, and gave change of garments unto them which expounded the riddle. And his anger was kindled, and he went up to his father's house. But Samson's wife was given to his companion, whom he had used as his friend. But it came to pass within a while after, in the time of wheat harvest, that Samson visited his wife with a kid; and he said, I will go in to my wife into the chamber. But her father would not suffer him to go in. And her father said, I verily thought that thou hadst utterly hated her; therefore I gave her to thy companion: is not her younger sister fairer than she? take her, I pray thee, instead of her.

And Samson said concerning them, Now shall I be more blameless than the Philistines, though I do them a displeasure. And Samson went and caught three hundred foxes, and took firebrands, and turned tail to tail, and put a firebrand in the midst between two tails. And when he had set the 
brands on fire, he let them go into the standing corn of the Philistines, and burnt up both the shocks, and also the standing corn, with the vineyards and olives. Then the Philistines said, Who hath done this? And they answered, Samson, the son in law of the Timnite, because he had taken his wife, and given her to his companion. And the Philistines came up, and burnt her and her father with fire. And Samson said unto them, Though ye have done this, yet will I be avenged of you, and after that I will cease. And he smote them hip and thigh with a great slaughter: and he went down and dwelt in the top of the rock Etam.

Then the Philistines went up, and pitched in Judah, and spread themselves in Lehi. And the men of Judah said, Why are ye come up against us? And they answered, To bind Samson are we come up, to do to him as he hath done to us. Then three thousand men of Judah went to the top of the rock Etam, and said to Samson, Knowest thou not that the Philistines are rulers over us? what is this that thou hast done unto us? And he said unto them, As they did unto me, so have I done unto them. And they said unto him, We are come down to bind thee, that we may deliver thee into the hand of the Philistines. And Samson said unto them, Swear unto me, that ye will not fall upon me yourselves. And they spake unto him, saying, $\mathrm{No}$; but we will bind thee fast, and deliver thee into their hand: but surely we will not kill thee. And they bound him with two new cords, and brought him up from the rock. And when he came unto Lehi, the Philistines shouted against him: and 
the Spirit of the Lord came mightily upon him, and the cords that were upon his arms became as flax that was burnt with fire, and his bands loosed from off his hands. And he found a new jawbone of an ass, and put forth his hand, and took it, and slew a thousand men therewith. And Samson said, With the jawbone of an ass, heaps upon heaps, with the jaw of an ass have I slain a thousand men. And it came to pass, when he had made an end of speaking, that he cast away the jawbone out of his hand, and called that place Ramath-lehi [i.e. "The hill of the jawbone"].

And he was sore athirst, and called on the Lord, and said, Thou hast given this great deliverance into the hand of thy servant: and now shall I die for thirst, and fall into the hand of the uncircumcised? But God clave an hollow place that was in the jaw, and there came water thereout; and when he had drunk, his spirit came again, and he revived: wherefore he called the name thereof En-hakkore [i.e. "The spring of him that called"], which is in Lehi unto this day. And he judged Israel in the days of the Philistines twenty years.

Then went Samson down to Gaza, and saw there an harlot, and went in unto her. And it was told the Gazites, saying, Samson is come hither. And they compassed him in, and laid wait for him all night in the gate of the city, and were quiet all the night, saying, In the morning, when it is day, we shall kill him. And Samson lay till midnight, and arose at midnight, and took the doors of the gate of the city, and the two posts, and went away with them, bar and all, and put them upon his shoulders, and 
carried them up to the top of an hill that is before Hebron.

And it came to pass afterward, that he loved a woman in the valley of Sorek, whose name was Delilah. And the lords of the Philistines came up unto her, and said unto her, Entice him, and see wherein his great strength lieth, and by what means we may prevail against him, that we may bind him to afflict him : and we will give thee every one of us eleven hundred pieces of silver. And Delilah said to Samson, Tell me, I pray thee, wherein thy great strength lieth, and wherewith thou mightest be bound to afflict thee. And Samson said unto her, If they bind me with seven green withs that were never dried, then shall I be weak, and be as another man. Then the lords of the Philistines brought up to her seven green withs which had not been dried, and she bound him with them. Now there were men lying in wait, abiding with her in the chamber. And she said unto him, The Philistines be upon thee, Samson. And he brake the withs, as a thread of tow is broken when it toucheth the fire. So his strength was not known.

And Delilah said unto Samson, Behold, thou hast mocked me, and told me lies: now tell me, I pray thee, wherewith thou mightest be bound. And he said unto her, If they bind me fast with new ropes that never were occupied, then shall I be weak, and be as another man. Delilah therefore took new ropes, and bound him therewith, and said unto him, The Philistines be upon thee, Samson. And there were liers in wait abiding in the chamber. And he brake them from off his arms like a thread. And 
Delilah said unto Samson, Hitherto thou hast mocked me, and told me lies: tell me wherewith thou mightest be bound. And he said unto her, If thou weavest the seven locks of my head with the web. And she fastened it with the pin, and said unto him, The Philistines be upon thee, Samson. And he awaked out of his sleep, and went away with the pin of the beam, and with the web.

And she said unto him, How canst thou say, I love thee, when thine heart is not with me? Thou hast mocked me these three times, and hast not told me wherein thy great strength lieth. And it came to pass, when she pressed him daily with her words, and urged him, so that his soul was vexed unto death; that he told her all his heart, and said unto her, There hath not come a razor upon mine head; for I have been a Nazarite unto God from my mother's womb: if I be shaven, then my strength will go from me, and I shall become weak, and be like any other man. And when Delilah saw that he had told her all his heart, she sent and called for the lords of the Philistines, saying, Come up this once, for he hath shewed me all his heart. Then the lords of the Philistines came up unto her, and brought money in their hand. And she made him sleep upon her knees; and she called for a man, and she caused him to shave off the seven locks of his head; and she began to afflict him, and his strength went from him. And she said, The Philistines be upon thee, Samson. And he awoke out of his sleep, and said, I will go out as at other times before, and shake myself. And he wist not that the Lord was departed from him. 
But the Philistines took him, and put out his eyes, and brought him down to Gaza, and bound him with fetters of brass; and he did grind in the prison house. Howbeit the hair of his head began to grow again after he was shaven. Then the lords of the Philistines gathered them together for to offer a great sacrifice unto Dagon their god, and to rejoice: for they said, Our god hath delivered Samson our enemy into our hand. And when the people saw him, they praised their god: for they said, Our god hath delivered into our hands our enemy, and the destroyer of our country, which slew many of us. And it came to pass, when their hearts were merry, that they said, Call for Samson, that he may make us sport. And they called for Samson out of the prison house; and he made them sport: and they set him between the pillars. And Samson said unto the lad that held him by the hand, Suffer me that I may feel the pillars whereupon the house standeth, that I may lean upon them. Now the house was full of men and women; and all the lords of the Philistines were there; and there were upon the roof about three thousand men and women, that beheld while Samson made sport. And Samson called unto the Lord, and said, O Lord God, remember me, I pray thee, and strengthen me, I pray thee, only this once, O God, that I may be at once avenged of the Philistines for my two eyes. And Samson took hold of the two middle pillars upon which the house stood, and on which it was borne up, of the one with his right hand, and of the other with his left. And Samson said, Let me die with the Philistines. And he bowed himself with 
all his might; and the house fell upon the lords, and upon all the people that were therein. So the dead which he slew at his death were more than they which he slew in his life. Then his brethren and all the house of his father came down, and took him, and brought him up, and buried him between Zorah and Eshtaol in the buryingplace of Manoah his father. And he judged Israel twenty years.

\section{XXIX.}

\section{TRutb.}

Ruth.

Now it came to pass in the days when the judges ruled, that there was a famine in the land. And a certain man of Beth-lehem-judah went to sojourn in the country of Moab, he, and his wife, and his two sons. And the name of the man was Elimelech, and the name of his wife Naomi, and the name of his two sons Mahlon and Chilion, Ephrathites of Beth-lehem-judah. And they came into the country of Moab, and continued there. And Elimelech Naomi's husband died; and she was left, and her two sons. And they took them wives of the women of Moab; the name of the one was Orpah, and the name of the other Ruth: and they dwelled there about ten years. And Mahlon and Chilion died also both of them; and the woman was left of her two sons and her husband.

Then she arose with her daughters in law, that she might return from the country of Moab: for she 
had heard in the country of Moab how that the Lord had visited his people in giving them bread. Wherefore she went forth out of the place where she was, and her two daughters in law with her; and they went on the way to return unto the land of Judah. And Naomi said unto her two daughters in law, Go, return each to her mother's house: the Lord deal kindly with you, as ye have dealt with the dead, and with me. The Lord grant you that ye may find rest, each of you in the house of her husband. Then she kissed them; and they lifted up their voice, and wept. And they said unto her, Surely we will return with thee unto thy people. And Naomi said, Turn again, my daughters: why will ye go with me? are there yet any more sons in my womb, that they may be your husbands? Turn again, my daughters, go your way; for I am too old to have an husband. If I should say, I have hope, if I should have an husband also to night, and should also bear sons; would ye tarry for them till they were grown? would ye stay for them from having husbands? nay, my daughters; for it grieveth me much for your sakes that the hand of the Lord is gone out against me. And they lifted up their voice and wept again: and Orpah kissed her mother in law; but Ruth clave unto her.

And she saicl, Behold, thy sister in law is gone back unto her people, and unto her gods: return thou after thy sister in law. And Ruth said, Intreat me not to leave thee, or to return from following after thee: for whither thou goest, I will go; and where thou lodgest, I will lodge: thy people shall be my people, and thy God my 
God: where thou diest, will I die, and there will I be buried: the Lord do so to me, and more also, if ought but death part thee and me. When she saw that she was stedfastly minded to go with her, then she left speaking unto her.

So they two went until they came to Beth-lehem. And it came to pass, when they were come to Bethlehem, that all the city was moved about them, and they said, Is this Naomi? And she said unto them, Call me not Naomi [i.e. "Pleasant"], call me Mara [i.e. "Bitter"] : for the Almighty hath dealt very bitterly with me. I went out full, and the Lord hath brought me home again empty: why then call ye me Naomi, seeing the Lord hath testified against me, and the Almighty hath afflicted me? So Naomi returned, and Ruth the Moabitess, her daughter in law, with her, which returned out of the country of Moab: and they came to Beth-lehem in the beginning of barley harvest.

And Naomi had a kinsman of her husband's, a mighty man of wealth, of the family of Elimelech; and his name was Boaz. And Ruth the Moabitess said unto Naomi, Let me now go to the field, and glean ears of corn after him in whose sight I shall find grace. And she said unto her, Go, my daughter. And she went, and came, and gleaned in the field after the reapers: and her hap was to light on a part of the field belonging unto Boaz, who was of the kindred of Elimelech.

And, behold, Boaz came from Beth-lehem, and said unto the reapers, The Lord be with you. And they answered him, The Lord bless thee. Then said Boaz unto his servant that was set over the 
reapers, Whose damsel is this? And the servant that was set over the reapers answered and said, It is the Moabitish damsel that came back with Naomi out of the country of Moab: and she said, I pray you, let me glean and gather after the reapers among the sheaves: so she came, and hath continued even from the morning until now, that she tarried a little in the house. Then said Boaz unto Ruth, Hearest thou not, my daughter? Go not to glean in another field, neither go from hence, but abide here fast by my maidens: let thine eyes be on the field that they do reap, and go thou after them: have I not charged the young men that they shall not touch thee? and when thou art athirst, go unto the vessels, and drink of that which the young men have drawn. Then she fell on her face, and bowed herself to the ground, and said unto him, Why have I found grace in thine eyes, that thou shouldest take knowledge of me, seeing I am a stranger? And Boaz answered and said unto her, It hath fully been shewed me, all that thou hast done unto thy mother in law since the death of thine husband; and how thou hast left thy father and thy mother, and the land of thy nativity, and art come unto a people which thou knewest not heretofore. The Lord recompense thy work, and a full reward be given thee of the Lord God of Israel, under whose wings thou art come to trust. Then she said, Let me find favour in thy sight, my lord; for that thou hast comforted me, and for that thou hast spoken friendly unto thine handmaid, though I be not like unto one of thine handmaidens. And Boaz said unto her, At mealtime come thou hither, and eat 
of the bread, and dip thy morsel in the vinegar. And she sat beside the reapers: and he reached her parched corn, and she did eat, and was sufficed, and left. And when she was risen up to glean, Boaz commanded his young men, saying, Let her glean even among the sheaves, and reproach her not: and let fall also some of the handfuls of purpose for her, and leave them, that she may glean them, and rebuke her not. So she gleaned in the field until even, and beat out that she had gleaned: and it was about an ephah of barley.

And she took it up, and went into the city: and her mother in law saw what she had gleaned: and she brought forth, and gave to her that she had reserved after she was sufficed. And her mother in law said unto her, Where hast thou gleaned to day? and where wroughtest thou? blessed be he that did take knowledge of thee. And she shewed her mother in law with whom she had wrought, and said, The man's name with whom I wrought to day is Boaz. And Naomi said unto her daughter in law, Blessed be he of the Lord, who hath not left off his kindness to the living and to the dead. And Naomi said unto her, The man is near of kin unto us, one of our next kinsmen. And Ruth the Moabitess said, He said unto me also, Thou shalt keep fast by my young men, until they have ended all my harvest. And Naomi said unto Ruth her daughter in law, It is good, my daughter, that thou go out with liis maidens, that they meet thee not in any other field. So she kept fast by the maidens of Boaz to glean unto the end of barley harvest and of wheat harvest; and dwelt with her mother in law. Then Naomi 
her mother in law said unto her, My daughter, shall I not seek rest for thee, that it may be well with thee? And now is not Boaz of our kindred, with whose maidens thou wast? Behold, he winnoweth barley to night in the threshingfloor. Wash thyself therefore, and anoint thee, and put thy raiment upon thee, and get thee down to the floor: but make not thyself known unto the man, until he shall have done eating and drinking. And it shall be, when he lieth down, that thou shalt mark the place where he shall lie, and thou shalt go in, and uncover his feet, and lay thee down; and he will tell thee what thou shalt do. And she said unto her, All that thou sayest unto me I will do.

And she went down unto the floor, and did according to all that her mother in law bade her. And when Boaz had eaten and drunk, and his heart was merry, he went to lie down at the end of the heap of corn: and she came softly, and uncovered his feet, and laid her down. And it came to pass at midnight, that the man was afraid, and turned himself : and, behold, a woman lay at his feet. And he said, Who art thou? And she answered, I am Ruth thine handmaid: spread therefore thy skirt over thine handmaid; for thou art a near kinsman. And he said, Blessed be thou of the Lord, my daughter: for thou hast shewed more kindness in the latter end than at the beginning, inasmuch as thou followedst not young men, whether poor or rich. And now, my daughter, fear not; I will do to thee all that thou requirest: for all the city of my people doth know that thou art a virtuous woman. And now it is true that I am thy near 
kinsman: howbeit there is a kinsman nearer than I. Tarry this night, and it shall be in the morning, that if he will perform unto thee the part of a kinsman, well; let him do the kinsman's part: but if he will not do the part of a kinsman to thee, then will I do the part of a kinsman to thee, as the Lord liveth: lie down until the morning.

And she lay at his feet until the morning: and she rose up before one could know another. And he said, Let it not be known that a woman came into the floor. Also he said, Bring the vail that thou hast upon thee, and hold it. And when she held it, he measured six measures of barley, and laid it on her: and she went into the city. And when she came to her mother in law, she said, Who art thou, my daughter? And she told her all that the man had done to her. And she said, These six measures of barley gave he me; for he said to me, Go not empty unto thy mother in law. Then said she, Sit still, my daughter, until thou know how the matter will fall: for the man will not be in rest. until he have finished the thing this day.

Then went Boaz up to the gate, and sat him down there: and, behold, the kinsman of whom Boaz spake came by ; unto whom he said, Ho, such a one! turn aside, sit down here. And he turned aside, and sat down. And he took ten men of the elders of the city, and said, Sit ye down here. And they sat down. And he said unto the kinsman, Naomi, that is come again out of the country of Moab, selleth a parcel of land, which was our brother Elimelech's: and I thought to advertise thee, saying, Buy it before the inhabitants, and before the 
elders of my people. If thou wilt redeem it, redeem it: but if thou wilt not redeem it, then tell me, that I may know: for there is none to redeem it beside thee; and I am after thee. And he said, I will redeem it. Then said Boaz, What day thou buyest the field of the hand of Naomi, thou must buy it also of Ruth the Moabitess, the wife of the dead, to raise up the name of the dead upon his inheritance. And the kinsman said, I cannot redeem it for myself, lest I mar mine own inheritance: redeem thou my right to thyself ; for I cannot redeem it. Now this was the manner in former time in Israel concerning redeeming and concerning changing, for to confirm all things; a man plucked off his shoe, and gave it to his neighbour: and this was a testimony in Israel. Therefore the kinsman said unto Boaz, Buy it for thee. So he drew off his shoe.

And Boaz said unto the elders, and unto all the people, Ye are witnesses this day, that I have bought all that was Elimelech's, and all that was Chilion's and Mahlon's, of the hand of Naomi. Moreover Ruth the Moabitess, the wife of Mahlon, have I purchased to be my wife, to raise up the name of the dead upon his inheritance, that the name of the dead be not cut off from among his brethren, and from the gate of his place: ye are witnesses this day. And all the people that were in the gate, and the elders, said, We are witnesses. The Lord make the woman that is come into thine house like Rachel and like Leah, which two did build the house of Israel: and do thou worthily in Ephratah, and be famous in Beth-lehem: and let thy house be like the house of Pharez, whom Tamar 
bare unto Judah, of the seed which the Lord shall give thee of this young woman.

So Boaz took Ruth, and she was his wife: and when he went in unto her, the Lord gave her conception, and she bare a son. And the women said unto Naomi, Blessed be the Lord, which hath not left thee this day without a kinsman, that his name may be famous in Israel. And he shall be unto thee a restorer of thy life, and a nourisher of thine old age: for thy daughter in law, which loveth thee, which is better to thee than seven sons, hath born him. And Naomi took the child, and laid it in her bosom and became nurse unto it. And the women her neighbours gave it a name, saying, There is a son born to Naomi; and they called his name Obed: he is the father of Jesse, the father of David.

Now these are the generations of Pharez: Pharez begat Hezron, and Hezron begat Ram, and Ram begat Amminadab, and Amminadab begat Nahshon, and Nahshon begat Salmon, and Salmon begat Boaz, and Boaz begat Obed, and Obed begat Jesse, and Jesse begat David.

\section{$\mathrm{XXX}$.}

\section{Tbe Call of Iamuel.}

I Samuel iii. I-20.

AND the child Samuel ministered unto the Lord before Eli. And the word of the Lord was precious in those days; there was no open vision. And it came to pass at that time, when Eli was laid down 
in his place, and his eyes began to wax dim, that he could not see; and ere the lamp of God went out in the temple of the Lord, where the ark of God was, and Samuel was laid down to sleep; that the Lord called Samuel: and he answered, Here am I. And he ran unto Eli, and said, Here am I; for thou calledst me. And he said, I called not; lie down again. And he went and lay down. And the Lord called yet again, Samuel. And Samuel arose and went to Eli, and said, Here am I; for thou didst call me. And he answered, I called not, my son; lie down again. Now Samuel did not yet know the Lord, neither was the word of the Lord yet revealed unto him. And the Lord called Samuel again the third time. And he arose and went to Eli, and said, Here am I; for thou didst call me. And Eli perceived that the Lord had called the child. Therefore Eli said unto Samuel, Go, lie down: and it shall be, if he call thee, that thou shalt say, Speak, Lord; for thy servant heareth. So Samuel went and lay down in his place. And the Lord came, and stood, and called as at other times, Samuel, Samuel. Then Samuel answered, Speak; for thy servant heareth.

And the Lord said to Samuel, Behold, I will do a thing in Israel, at which both the ears of every one that heareth it shall tingle. In that day I will perform against Eli all things which I have spoken concerning his house: when I begin, I will also make an end. For I have told him that I will judge his house for ever for the iniquity which he knoweth; because his sons made themselves vile, and he restrained them not. And therefore I have 
sworn unto the house of Eli, that the iniquity of Eli's house shall not be purged with sacrifice nor offering for ever.

And Samuel lay until the morning, and opened the doors of the house of the Lord. And Samuel feared to shew Eli the vision. Then Eli called Samuel, and said, Samuel, my son. And he answered, Here am I. And he said, What is the thing that the Lord hath said unto thee? I pray thee hide it not from me: God do so to thee, and more also, if thou hide any thing from me of all the things that he said unto thee. And Samuel told him every whit, and hid nothing from him. And he said, It is the Lord: let him do what seemeth him good.

And Samuel grew, and the Lord was with him, and did let none of his words fall to the ground. And all Israel from Dan even to Beer-sheba knew that Samuel was established to be a prophet of the Lord.

\section{XXXI. \\ Tbe $\mathcal{F}$ rk of the Covenant.}

I Samuel iv. I-I8.

And the word of Samuel came to all Israel. Now Israel went out against the Philistines to battle, and pitched beside Eben-ezer: and the Philistines pitched in Aphek. And the Philistines put themselves in array against Israel: and when they joined battle, Israel was smitten before the Philis- 
tines: and they slew of the army in the field about four thousand men. And when the people were come into the camp, the elders of Israel said, Wherefore hath the Lord smitten us to day before the Philistines? Let us fetch the ark of the covenant of the Lord out of Shiloh unto us, that, when it cometh among us, it may save us out of the hand of our enemies. So the people sent to Shiloh, that they might bring from thence the ark of the covenant of the Lord of hosts, which dwelleth between the cherubims: and the two sons of Eli, Hophni and Phinehas, were there with the ark of the covenant of God. And when the ark of the covenant of the Lord came into the camp, all Israel shouted with a great shout, so that the earth rang again. And when the Philistines heard the noise of the shout, they said, What meaneth the noise of this great shout in the camp of the Hebrews? And they understood that the ark of the Lord was come into the camp. And the Philistines were afraid, for they said, God is come into the camp. And they said, Woe unto us! for there hath not been such a thing heretofore. Woe unto us! who shall deliver us out of the hand of these mighty Gods? these are the Gods that smote the Egyptians with all the plagues in the wilderness. Be strong, and quit yourselves like men, $O$ ye Philistines, that ye be not servants unto the Hebrews, as they have been to you: quit yourselves like men, and fight. And the Philistines fought, and Israel was smitten, and they fled every man into his tent: and there was a very great slaughter; for there fell of Israel thirty thousand footmen. And the ark of God was taken; 
and the two sons of Eli, Hophni and Phinehas, were slain.

And there ran a man of Benjamin out of the army, and came to Shiloh the same day with his clothes rent, and with earth upon his head. And when he came, lo, Eli sat upon a seat by the wayside watching: for his heart trembled for the ark of God. And when the man came into the city, and told it, all the city cried out. And when Eli heard the noise of the crying, he said, What meaneth the noise of this tumult? And the man came in hastily, and told Eli. Now Eli was ninety and eight years old; and his eyes were dim, that he could not see. And the man said unto Eli, I am he that came out of the army, and I fled to day out of the army. And he said, What is there done, my son? And the messenger answered and said, Israel is fled before the Philistines, and there hath been also a great slaughter among the people, and thy two sons also, Hophni and Phinehas, are dead, and the ark of God is taken. And it came to pass, when he made mention of the ark of God, that he fell from off the seat backward by the side of the gate, and his neck brake, and he died: for he was an old man, and heavy. And he had judged Israel forty years.

\section{XXXII.}

\section{The Anointing of Iaul.}

I Samuel viii.-x. 9.

And it came to pass, when Samuel was old, that he made his sons judges over Israel. Now the 
name of his firstborn was Joel; and the name of his second, Abiah: they were judges in Beer-sheba. And his sons walked not in his ways, but turned aside after lucre, and took bribes, and perverted judgment. Then all the elders of Israel gathered themselves together, and came to Samuel unto Ramah, and said unto him, Behold, thou art old, and thy sons walk not in thy ways: now make us a king to judge us like all the nations.

But the thing displeased Samuel, when they said, Give us a king to judge us. And Samuel prayed unto the Lord. And the Lord said unto Samuel, Hearken unto the voice of the people in all that they say unto thee: for they have not rejected thee, but they have rejected me, that I should not reign over them. According to all the works which they have done since the day that I brought them up out of Egypt even unto this day, wherewith they have forsaken me, and served other gods, so do they also unto thee. Now therefore hearken unto their voice: howbeit yet protest solemnly unto them, and shew them the manner of the king that shall reign over them.

And Samuel told all the words of the Lord unto the people that asked of him a king. And he said, This will be the manner of the king that shall reign over you: he will take your sons, and appoint them for himself, for his chariots, and to be his horsemen; and some shall run before his chariots. And he will appoint him captains over thousands, and captains over fifties; and will set them to ear [i.e. "plough"] his ground, and to reap his harvest, and to make his instruments of war, and instruments of 
his chariots. And he will take your daughters to be confectionaries, and to be cooks, and to be bakers. And he will take your fields, and your vineyards, and your oliveyards, even the best of them, and give them to his servants. And he will take the tenth of your seed, and of your vineyards, and give to his officers, and to his servants. And he will take your menservants, and your maidservants, and your goodliest young men, and your asses, and put them to his work. He will take the tenth of your sheep: and ye shall be his servants. And ye shall cry out in that day because of your king which ye shall have chosen you; and the Lord will not hear you in that day.

Nevertheless the people refused to obey the voice of Samuel; and they said, Nay; but we will have a king over us; that we also may be like all the nations; and that our king may judge us, and go out before us, and fight our battles. And Samuel heard all the words of the people, and he rehearsed them in the ears of the Lord. And the Lord said to Samuel, Hearken unte their voice, and make them a king. And Samuel said unto the men of Israel, Go ye every man unto his city.

Now there was a man of Benjamin, whose name was Kish, the son of Abiel, the son of Zeror, the son of Bechorath, the son of Aphiah, a Benjamite, a mighty man of power. And he had a son, whose name was Saul, a choice young man, and a goodly: and there was not among the children of Israel a goodlier person that he: from his shoulders and upward he was higher than any of the people.

And the asses of Kish Saul's father were lost. 
And Kish said to Saul his son, Take now one of the servants with thee, and arise, go seek the asses. And he passed through mount Ephraim, and passed through the land of Shalisha, but they found them not: then they passed through the land of Shalim, and there they were not: and he passed through the land of the Benjamites, but they found them not. And when they were once come to the land of Zuph, Saul said to his servant that was with him, Come, and let us return; lest my father leave caring for the asses, and take thought for us. And he said unto him, Behold now, there is in this city a man of God, and he is an honourable man; all that he saith cometh surely to pass: now let us go thither; peradventure he can shew us our way that we should go. Then said Saul to his servant, But, behold, if we go, what shall we bring the man? for the bread is spent in our vessels, and there is not a present to bring to the man of God: what have we? And the servant answered Saul again, and said, Behold, I have here at hand the fourth part of a shekel of silver: that will I give to the man of God, to tell us our way. (Beforetime in Israel, when a man went to enquire of God, thus he spake, Come, and let us go to the seer: for he that is now called a Prophet was beforetime called a Seer.) Then said Saul to his servant, Well said; come, let us go. So they went unto the city where the man of God was.

And as they went up the hill to the city, they found young maidens going out to draw water, and said unto them, Is the seer here? And they answered them, and said, He is ; behold, he is before 
you: make haste now, for he came to day to the city; for there is a sacrifice of the people to day in the high place: as soon as ye come into the city, ye shall straightway find him, before he go up to the high place to eat: for the people will not eat until he come, because he doth bless the sacrifice; and afterwards they eat that be bidden. Now therefore get you up; for about this time ye shall find him. And they went up into the city: and when they were come into the city, behold, Samuel came out against them, for to go up to the high place.

Now the Lord had told Samuel in his ear a day before Saul came, saying, To morrow about this time I will send thee a man out of the land of Benjamin, and thou shalt anoint him to be captain over my people Israel, that he may save my people out of the hand of the Philistines: for I have looked upon my people, because their cry is come unto me. And when Samuel saw Saul, the Lord said unto him, Behold the man whom I spake to thee of! this same shall reign over my people. Then Saul drew near to Samuel in the gate, and said, Tell me, I pray thee, where the seer's house is. And Samuel answered Saul, and said, I am the seer: go up before me unto the high place; for ye shall eat with me to day, and to morrow I will let thee go, and will tell thee all that is in thine heart. And as for thine asses that were lost three days ago, set not thy mind on them; for they are found. And on whom is all the desire of Israel? Is it not on thee, and on all thy father's house? And Saul answered and said, Am not I a Benjamite, of the smallest of the tribes of Israel? and my family the least of all the 
families of the tribe of Benjamin? wherefore then speakest thou so to me? And Samuel took Saul and his servant, and brought them into the parlour, and made them sit in the chiefest place among them that were bidden, which were about thirty persons. And Samuel said unto the cook, Bring the portion which I gave thee, of which I said unto thee, Set it by thee. And the cook took up the shoulder, and that which was upon it, and set it before Saul. And Samuel said, Behold that which is left! set it before thee, and eat: for unto this time hath it been kept for thee since I said, I have invited the people. So Saul did eat with Samuel that day.

And when they were come down from the high place into the city, Samuel communed with Saul upon the top of the house. And they arose early: and it came to pass about the spring of the day, that Samuel called Saul to the top of the house, saying, Up, that I may send thee away. And Saul arose, and they went out both of them, he and Samuel, abroad. And as they were going down to the end of the city, Samuel said to Saul, Bid the servant pass on before us, (and he passed on,) but stand thou still a while, that I may shew thee the word of God.

Then Samuel took a vial of oil, and poured it upon his head, and kissed him, and said, Is it not because the Lord hath anointed thee to be captain over his inheritance? When thou art departed from me to day, then thou shalt find two men by Rachel's sepulchre in the border of Benjamin at Zelzah; and they will say unto thee, The asses which thou wentest to seek are found: and, lo, thy 
father hath left the care of the asses, and sorroweth for you, saying, What shall I do for my son? Then shalt thou go on forward from thence, and thou shalt come to the plain of Tabor, and there shall meet thee three men going up to God to Beth-el, one carrying three kids, and another carrying three loaves of bread, and another carrying a bottle of wine: and they will salute thee, and give thee two loaves of bread; which thou shalt receive of their hands. After that thou shalt come to the hill of God, where is the garrison of the Philistines: and it shall come to pass, when thou are come thither to the city, that thou shalt meet a company of prophets coming down from the high place with a psaltery, and a tabret, and a pipe, and a harp, before them; and they shall prophesy: and the Spirit of the Lord will come upon thee, and thou shalt prophesy with them, and shalt be turned into another man. And let it be, when these signs are come unto thee, that thou do as occasion serve thee; for God is with thee. And thou shalt go down before me to Gilgal ; and, behold, I will come down unto thee, to offer burnt offerings, and to sacrifice sacrifices of peace offerings: seven days shalt thou tarry, till I come to thee, and shew thee what thou shalt do.

And it was so, that when he had turned his back to go from Samuel, God gave him another heart: and all those signs came to pass that day. 


\section{XXXIII.}

\section{Fonatban ano bis $\mathfrak{A}$ rmourbearer.}

I Samuel xiv. r-23.

Now it came to pass upon a day, that Jonathan the son of Saul said unto the young man that bare his armour, Come, and let us go over to the Philistines' garrison, that is on the other side. But he told not his father. And Saul tarried in the uttermost part of Gibeah under a pomegranate tree which is in Migron: and the people that were with him were about six hundred men; and Ahiah, the son of Ahitub, I-chabod's brother, the son of Phinehas, the son of Eli, the Lord's priest in Shiloh, wearing an ephod. And the people knew not that Jonathan was gone.

And between the passages, by which Jonathan sought to go over unto the Philistines' garrison, there was a sharp rock on the one side, and a sharp rock on the other side: and the name of the one was Bozez, and the name of the other Seneh. The forefront of the one was situate northward over against Michmash, and the other southward over against Gibeah. And Jonathan said to the young man that bare his armour, Come, and let us go over unto the garrison of these uncircumcised: it may be that the Lord will work for us: for there is no restraint to the Lord to save by many or by few.

And his armourbearer said unto him, Do all that is in thy heart: turn thee; behold, I am with thee according to thy heart. Then said Jonathan, Be- 
hold, we will pass over unto these men, and we will discover ourselves unto them. If they say thus unto us, Tarry until we come to you; then we will stand still in our place, and will not go up unto them. But if they say thus, Come up unto us; then we will go up: for the Lord hath delivered them into our hand: and this shall be a sign unto us. And both of them discovered themselves unto the garrison of the Philistines: and the Philistines said, Behold, the Hebrews come forth out of the holes where they had hid themselves. And the men of the garrison answered Jonathan and his armourbearer, and said, Come up to us, and we will shew you a thing. And Jonathan said unto his armourbearer, Come up after me: for the Lord hath delivered them into the hand of Israel. And Jonathan climbed up upon his hands and upon his feet, and his armourbearer after him: and they fell before Jonathan; and his armourbearer slew after him. And that first slaughter, which Jonathan and his armourbearer made, was about twenty men, within as it were an half acre of land, which a yoke of oxen might plow.

And there was trembling in the host, in the field, and among all the people: the garrison, and the spoilers, they also trembled, and the earth quaked: so it was a very great trembling. And the watchmen of Saul in Gibeah of Benjamin looked; and behold, the multitude melted away, and they went on beating down one another. Then said Saul unto the people that were with him, Number now, and see who is gone from us. And when they had numbered, behold, Jonathan and his armourbearer 
were not there. And Saul said unto Ahiah, Bring hither the ark of God. For the ark of God was at that time with the children of Israel. And it came to pass, while Saul talked unto the priest, that the noise that was in the host of the Philistines went on and increased: and Saul said unto the priest, Withdraw thine hand. And Saul and all the people that were with him assembled themselves, and they came to the battle: and, behold, every man's sword was against his fellow, and there was a very great discomfiture. Moreover the Hebrews that were with the Philistines before that time, which went up with them into the camp from the country round about, even they also turned to be with the Israelites that were with Saul and Jonathan. Likewise all the men of Israel which had hid themselves in mount Ephraim, when they heard that the Philistines fled, even they also followed hard after them in the battle. So the Lord saved Israel that day: and the battle passed over unto Beth-aven.

\section{XXXIV.}

\section{জaul's Disobedience.}

I Samuel xv.

Samuel also said unto Saul, The Lord sent me to anoint thee to be king over his people, over Israel : now therefore hearken thou unto the voice of the words of the Lord. Thus saith the Lord of hosts, I remember that which Amalek did to Israel, how he laid wait for him in the way, when he came up 
from Egpyt. Now go and smite Amalek, and utterly destroy all that they have, and spare them not; but slay both man and woman, infant and suckling, ox and sheep, camel and ass.

And Saul gathered the people together, and numbered them in Telain, two hundred thousand footmen, and ten thousand men of Judah. And Saul came to a city of Amalek, and laid wait in the valley. And Saul said unto the Kenites, Go, depart, get you down from among the Amalekites, lest I destroy you with them: for ye shewed kindness to all the children of Israel, when they came up out of Egypt. So the Kenites departed from among the Amalekites. And Saul smote the Amalekites from Havilah until thou comest to Shur, that is over against Egypt. And he took Agag the king of the Amalekites alive, and utterly destroyed all the people with the edge of the sword. But Saul and the people spared Agag, and the best of the sheep, and of the oxen, and of the fatlings, and the lambs, and all that was good, and would not utterly destroy them: but every thing that was vile and refuse, that they destroyed utterly.

Then came the word of the Lord unto Samuel, saying, It repenteth me that I have set up Saul to be king: for he is turned back from following me, and hath not performed my commandments. And it grieved Samuel; and he cried unto the Lord all night. And when Samuel rose early to meet Saul in the morning, it was told Samuel, saying, Saul came to Carmel, and, behold, he set him up a place, and is gone about, and passed on, and gone lown to Gilgal. And Samuel came to Saul: and Saul 
said unto him, Blessed be thou of the Lord: I have performed the commandment of the Lord. And Samuel said, What meaneth then this bleating of the sheep in mine ears, and the lowing of the oxen which I hear? And Saul said, They have brought them from the Amalekites: for the people spared the best of the sheep and of the oxen, to sacrifice unto the Lord thy God; and the rest we have utterly destroyed. Then Samuel said unto Saul, Stay, and I will tell thee what the Lord hath said to me this night. And he said unto him, Say on. And Samuel said, When thou wast little in thine own sight, wast thou not made the head of the tribes of Israel, and the Lord anointed thee king over Israel? And the Lord sent thee on a journey, and said, Go and utterly destroy the sinners the Amalekites, and fight against them until they be consumed. Wherefore then didst thou not obey the voice of the Lord, but didst fly upon the spoil, and didst evil in the sight of the Lord? And Saul said unto Samuel, Yea, I have obeyed the voice of the Lord, and have gone the way which the Lord sent me, and have brought Agag the king of Amalek, and have utterly destroyed the Amalekites. But the people took of the spoil, sheep and oxen, the chief of the things which should have been utterly destroyed, to sacrifice unto the Lord thy God in Gilgal. And Samuel said, Hath the Lord as great delight in burnt offerings and sacrifices, as in obeying the voice of the Lord? Behold, to obey is better than sacrifice, and to hearken than the fat of rams. For rebellion is as the sin of witchcraft, and stubbornness is as iniquity and idolatry. Because thou hast 
rejected the word of the Lord, he hath also rejected thee from being king.

And Saul said unto Samuel, I have sinned: for I have transgressed the commandment of the Lord, and thy words: because I feared the people, and obeyed their voice. Now therefore, I pray thee, pardon my sin, and turn again with me, that I may worship the Lord. And Samuel said unto Saul, I will not return with thee: for thou hast rejected the word of the Lord, and the Lord hath rejected thee from being king over Israel. And as Samuel turned about to go away, he laid hold upon the skirt of his mantle, and it rent. And Samuel said unto him, The Lord hath rent the kingdom of Israel from thee this day, and hath given it to a neighbour of thine, that is better than thou. And also the Strength of Israel will not lie nor repent: for he is not a man, that he should repent. Then he said, I have sinned: yet honour me now, I pray thee, before the elders of my people, and before Israel, and turn again with me, that I may worship the Lord thy God. So Samuel turned again after Saul; and Saul worshipped the Lord.

Then said Samuel, Bring ye hither to me Agag the king of the Amalekites. And Agag came unto him delicately. And Agag said, Surely the bitterness of death is past. And Samuel said, As thy sword hath made women childless, so shall thy mother be childless among women. And Samuel hewed Agag in pieces before the Lord in Gilgal.

Then Samuel went to Ramah; and Saul went up to his house to Gibeah of Saul. And Samuel came no more to see Saul until the day of his death: 
nevertheless Samuel mourned for Saul: and the Lord repented that he had made Saul king over Israel.

\section{XXXV.}

\section{Tbe $\mathfrak{E}$ nointing of $\boxplus$ avido.}

I Samuel xvi.

And the Lord said unto Samuel, How long wilt thou mourn for Saul, seeing I have rejected him from reigning over Israel? fill thine horn with oil, and go, I will send thee to Jesse the Beth-lehemite: for I have provided me a king among his sons. And Samuel said, How can I go? if Saul hear it, he will kill me. And the Lord said, Take an heifer with thee, and say, I am come to sacrifice to the Lord. And call Jesse to the sacrifice, and I will shew thee what thou shalt do: and thou shalt anoint unto me him whom I name unto thee.

And Samuel did that which the Lord spake, and came to Beth-lehem. And the elders of the town trembled at his coming, and said, Comest thou peaceably? And he said, Peaceably: I am come to sacrifice unto the Lord: sanctify yourselves, and come with me to the sacrifice. And he sanctified Jesse and his sons, and called them to the sacrifice. And it came to pass, when they were come, that he looked on Eliab, and said, Surely the Lord's anointed is before him. But the Lord said unto Samuel, Look not on his countenance, or on the height of his stature; because I have refused him: for the Lord secth not as man seeth; for man 
looketh on the outward appearance, but the Lord looketh on the heart. Then Jesse called Abinadab, and made him pass before Samuel. And he said, Neither hath the Lord chosen this. Then Jesse made Shammah to pass by. And he said, Neither hath the Lord chosen this. Again, Jesse made seven of his sons to pass before Samuel. And Samuel said unto Jesse, The Lord hath not chosen these. And Samuel said unto Jesse, Are here all thy children? And he said, There remaineth yet the youngest, and, behold, he keepeth the sheep. And Samuel said unto Jesse, Send and fetch him: for we will not sit down till he come hither. And he sent, and brought him in. And he was ruddy, and withal of a beautiful countenance, and goodly to look to. And the Lord said, Arise, anoint him: for this is he. Then Samuel took the horn of oil, and anointed him in the midst of his brethren: and the Spirit of the Lord came upon David from that day forward. So Samuel rose up, and went to Ramah.

But the Spirit of the Lord departed from Saul, and an evil spirit from the Lord troubled him. And Saul's servants said unto him, Behold now, an evil spirit from God troubleth thee. Let our lord now command thy servants, which are before thee, to seek out a man, who is a cunning player on an harp: and it shall come to pass, when the evil spirit from God is upon thee, that he shall play with his hand, and thou shalt be well. And Saul said unto his servants, Provide me now a man that can play well, and bring him to me. Then answered one of the servants, and said, Behold, I have seen a son of 
Jesse the Beth-lehemite, that is cunning in playing, and a mighty valiant man, and a man of war, and prudent in matters, and a comely person, and the Lord is with him. Wherefore Saul sent messengers unto Jesse, and said, Send me David thy son, which is with the sheep. And Jesse took an ass laden with bread, and a bottle of wine, and a kid, and sent them by David his son unto Saul. And David came to Saul, and stood before him: and he loved him greatly; and he became his armourbearer. And Saul sent to Jesse, saying, Let David, I pray thee, stand before me; for he hath found favour in my sight. And it came to pass, when the evil spirit from God was upon Saul, that David took an harp, and played with his hand: so Saul was refreshed, and was well, and the evil spirit departed from him.

\section{XXXVI.}

\section{Đavio ano Goliatb.}

I Samuel xvii.-xviii. I6.

Now the Philistines gathered together their armies to battle, and were gathered together at Shochoh, which belongeth to Judah, and pitched between Shochoh and Azekah, in Ephes-dammim. And Saul and the men of Israel were gathered together, and pitched by the valley of Elah, and set the battle in array against the Philistines. And the Philistines stood on a mountain on the one side, and Israel stood on a mountain on the other side: and there was a valley between them. 
And there went out a champion out of the camp of the Philistines, named Goliath, of Gath, whose height was six cubits and a span. And he had an helmet of brass upon his head, and he was armed with a coat of mail; and the weight of the coat was five thousand shekels of brass. And he had greaves of brass upon his legs, and a target of brass between his shoulders. And the staff of his spear was like a weaver's beam; and his spear's head weighed six hundred shekels of iron: and one bearing a shield went before him. And he stood and cried unto the armies of Israel, and said unto them, Why are ye come out to set your battle in array? am not I a Philistine, and ye servants to Saul? choose you a man for you, and let him come down to me. If he be able to fight with me, and to kill me, then will we be your servants: but if I prevail against him, and kill him, then shall ye be our servants, and serve us. And the Philistine said, I defy the armies of Israel this day; give me a man, that we may fight together. When Saul and all Israel heard those words of the Philistine, they were dismayed, and greatly afraid.

Now David was the son of that Ephrathite of Beth-lehem-judah, whose name was Jesse; and he had eight sons: and the man went among men for an old man in the days of Saul. And the three eldest sons of Jesse went and followed Saul to the battle: and the names of his three sons that went to the battle were Eliab the firstborn, and next unto him Abinadab, and the third Shammah. And David was the youngest: and the three eldest followed Saul. But David went and returned from 
Saul to feed his father's sheep at Beth-lehem. And the Philistine drew near morning and evening, and presented himself forty days. And Jesse said unto David his son, Take now for thy brethren an ephah of this parched corn, and these ten loaves, and run to the camp to thy brethren; and carry these ten cheeses unto the captain of their thousand, and look how thy brethren fare, and take their pledge. Now Saul, and they, and all the men of Israel, were in the valley of Elah, fighting with the Philistines. And David rose up early in the morning, and left the sheep with a keeper, and took, and went, as Jesse had commanded him; and he came to the trench, as the host was going forth to the fight, and shouted for the battle. For Israel and the Philistines had put the battle in array, army against army. And David left his carriage in the hand of the keeper of the carriage, and ran into the army, and came and saluted his brethren. And as he talked with them, behold, there came up the champion, the Philistine of Gath, Goliath by name, out of the armies of the Philistines, and spake according to the same words: and David heard them.

And all the men of Israel, when they saw the man, fled from him, and were sore afraid. And the men of Israel said, Have ye seen this man that is come up? surely to defy Israel is he come up: and it shall be, that the man who killeth him, the king will enrich him with great riches, and will give him his daughter, and make his father's house free in Israel. And David spake to the men that stood by him, saying, What shall be done to the man that killeth this Philistine, and taketh away the reproach 
from Israel? for who is this uncircumcised Philistine, that he should defy the armies of the living God? And the people answered him after this manner, saying, So shall it be done to the man that killeth him.

And Eliab his eldest brother heard when he spake unto the men; and Eliab's anger was kindled against David, and he said, Why camest thou down hither? and with whom hast thou left those few sheep in the wilderness? I know thy pride, and the naughtiness of thine heart; for thou art come down that thou mightest see the battle. And David said, What have I now done? Is there not a cause? And he turned from him toward another, and spake after the same manner: and the people answered him again after the former manner. And when the words were heard which David spake, they rehearsed them before Saul: and he sent for him.

And David said to Saul, Let no man's heart fail because of him; thy servant will go and fight with this Philistine. And Saul said to David, Thou art not able to go against this Philistine to fight with him: for thou art but a youth, and he a man of war from his youth. And David said unto Saul, Thy servant kept his father's sheep, and there came a lion, and a bear, and took a lamb out of the flock: and I went out after him, and smote him, and delivered it out of his mouth: and when he arose against me, I caught him by his beard, and smote him, and slew him. Thy servant slew both the lion and the bear: and this uncircumcised Philistine shall be as one of them, seeing he hath defied the armies 
of the living God. David said moreover, The Lord that delivered me out of the paw of the lion, and out of the paw of the bear, he will deliver me out of the hand of this Philistine. And Saul said unto David, Go, and the Lord be with thee.

And Saul armed David with his armour, and he put an helmet of brass upon his head; also he armed him with a coat of mail. And David girded his sword upon his armour, and he assayed to go; for he had not proved it. And David said unto Saul, I cannot go with these; for I have not proved them. And David put them off him. And he took his staff in his hand, and chose him five smooth stones out of the brook, and put them in a shepherd's bag which he had, even in a scrip; and his sling was in his hand: and he drew near to the Philistine. And the Philistine came on and drew near unto David; and the man that bare the shield went before him. And when the Philistine looked about, and saw David, he disdained him: for he was but a youth, and ruddy, and of a fair countenance. And the Philistine said unto David, Am I a dog, that thou comest to me with staves? And the Philistine cursed David by his gods. And the Philistine said to David, Come to me, and I will give thy flesh unto the fowls of the air, and to the beasts of the field. Then said David to the Philistine, Thou comest to me with a sword, and with a spear, and with a shield: but I come to thee in the name of the Lord of hosts, the God of the armies of Israel, whom thou hast defied. This day will the Lord deliver thee into mine hand; and I will smite thee, and take thine head from thee; and I 
will give the carcases of the host of the Philistines this day unto the fowls of the air, and to the wild beasts of the earth; that all the earth may know that there is a God in Israel. And all this assembly shall know that the Lord saveth not with sword and spear: for the battle is the Lord's, and he will give you into our hands.

And it came to pass, when the Philistine arose, and came and drew nigh to meet David, that David hasted, and ran toward the army to meet the Philistine. And David put his hand in his bag, and took thence a stone, and slang it, and smote the Philistine in his forehead, that the stone sunk into his forehead; and he fell upon his face to the earth. So David prevailed over the Philistine with a sling and with a stone, and smote the Philistine, and slew him; but there was no sword in the hand of David. Therefore David ran, and stood upon the Philistine, and took his sword, and drew it out of the sheath thereof, and slew him, and cut off his head therewith. And when the Philistines saw their champion was dead, they fled. And the men of Israel and of Judah arose, and shouted, and pursued the Philistines, until thou come to the valley, and to the gates of Ekron. And the wounded of the Philistines fell down by the way to Shaaraim, even unto Gath, and unto Ekron. And the children of Israel returned from chasing after the Philistines, and they spoiled their tents. And David took the head of the Philistine, and brought it to Jerusalem; but he put his armour in his tent.

And when Saul saw David go forth against the Philistine, he said unto Abner, the captain of the 
host, Abner, whose son is this youth? And Abner said, As thy soul liveth, O king, I cannot tell. And the king said, Enquire thou whose son the stripling is. And as David returned from the slaughter of the Philistine, Abner took him, and brought him before Saul with the head of the Philistine in his hand. And Saul said to him, Whose son art thou, thou young man? And David answered, I am the son of thy servant Jesse the Beth-lehemite.

And it came to pass, when he had made an end of speaking unto Saul, that the soul of Jonathan was knit with the soul of David, and Jonathan loved him as his own soul. And Saul took him that day, and would let him go no more home to his father's house. Then Jonathan and David made a covenant, because he loved him as his own soul. And Jonathan stripped himself of the robe that was upon him, and gave it to David, and his garments, even to his sword, and to his bow, and to his girdle. And David went out whithersoever Saul sent him, and behaved himself wisely: and Saul set him over the men of war, and he was accepted in the sight of all the people, and also in the sight of Saul's servants. And it came to pass as they came, when David was returned from the slaughter of the Philistine, that the women came out of all cities of Israel, singing and dancing, to meet king Saul, with tabrets, with joy, and with instruments of musick. And the women answered one another as they played, and said, Saul hath slain his thousands, and David his ten thousands. And Sau! was very wroth, and the saying displeased hirr; and he said, They have ascribed unto David 
ten thousands, and to me they have ascribed but thousands: and what can he have more but the kingdom? And Saul eyed David from that day and forward.

And it came to pass on the morrow, that the evil spirit from God came upon Saul, and he prophesied in the midst of the house: and David played with his hand, as at other times: and there was a javelin in Saul's hand. And Saul cast the javelin; for he said, I will smite David even to the wall with it. And David avoided out of his presence twice. And Saul was afraid of David, because the Lord was with him, and was departed from Saul. Therefore Saul removed him from him, and made him his captain over a thousand; and he went out and came in before the people. And David behaved himself wisely in all his ways; and the Lord was with him. Wherefore when Saul saw that he behaved himself very wisely, he was afraid of him. But all Israel and Judah loved David, because he went out and came in before them.

\section{XXXVII.}

\section{Đaví and Fonatban.}

I Samuel xx.

And David fled from Naioth in Ramah, and came and said before Jonathan, What have I done? what is mine iniquity? and what is my sin before thy father, that he seeketh my life? And he said unto him, God forbid; thou shalt not die: behold, my father will do nothing either great or small, 
but that he will shew it me: and why should my father hide this thing from me? it is not so. And David sware moreover, and said, Thy father certainly knoweth that I have found grace in thine eyes; and he saith, Let not Jonathan know this, lest he be grieved: but truly as the Lord liveth, and as thy soul liveth, there is but a step between me and death. Then said Jonathan unto David, Whatsoever thy soul desireth, I will even do it for thee. And David said unto Jonathan, Behold, to morrow is the new moon, and I should not fail to sit with the king at meat: but let me go, that I may hide myself in the field unto the third day at even. If thy father at all miss me, then say, David earnestly asked leave of me that he might run to Beth-lehem his city: for there is a yearly sacrifice there for all the family. If he say thus, It is well; thy servant shall have peace: but if he be very wroth, then be sure that evil. is determined by him. Therefore thou shalt deal kindly with thy servant; for thou hast brought thy servant into a covenant of the Lord with thee: notwithstanding, if there be in me iniquity, slay me thyself; for why shouldest thou bring me to thy father?

And Jonathan said, Far be it from thee: for if I knew certainly that evil were determined by my father to come upon thee, then would not I tell it thee? Then said David to Jonathan, Who shall tell me? or what if thy father answer thee roughly?

And Jonathan said unto David, Come, and let us go out into the field. And they went out both of them into the field. And Jonathan said unto David, O Lord God of Israel, when I have sounded my 
father about to morrow any time, or the third day, and, behold, if there be good toward David, and I then send not unto thee, and shew it thee; the Lord do so and much more to Jonathan: but if it please my father to do thee evil, then I will shew it thee, and send thee away, that thou mayest go in peace, and the Lord be with thee, as he hath been with my father. And thou shalt not only while yet I live shew me the kindness of the Lord, that I die not: but also thou shalt not cut off thy kindness from my house for ever: no, not when the Lord hath cut off the enemies of David every one from the face of the earth. So Jonathan made a covenant with the house of David, saying, Let the Lord even require it at the hand of David's enemies. And Jonathan caused David to swear again, because he loved him: for he loved him as he loved his own soul.

Then Jonathan said to David, To morrow is the new moon: and thou shalt be missed, because thy seat will be empty. And when thou hast stayed three days, then thou shalt go down quickly, and come to the place where thou didst hide thyself when the business was in hand, and shalt remain by the stone Ezel. And I will shoot three arrows on the side thereof, as though I shot at a mark. And, behold, I will send a lad, saying, Go, find out the arrows. If I expressly say unto the lad, Behold, the arrows are on this side of thee, take them; then come thou: for there is peace to thee, and no hurt; as the Lord liveth. But if I say thus unto the young man, Behold, the arrows are beyond thee; go thy way: for the Lord hath sent thee away. 
And as touching the matter which thou and I have spoken of, behold, the Lord be between thee and me for ever.

So David hid himself in the field: and when the new moon was come, the king sat him down to eat meat. And the king sat upon his seat, as at other times, even upon a seat by the wall: and Jonathan arose, and Abner sat by Saul's side, and David's place was empty. Nevertheless Saul spake not any thing that day: for he thought, Something hath befallen him, he is not clean; surely he is not clean.

And it came to pass on the morrow, which was the second day of the month, that David's place was empty: and Saul said unto Jonathan his son, Wherefore cometh not the son of Jesse to meat, neither yesterday, nor to day? And Jonathan answered Saul, David earnestly asked leave of me to go to Beth-lehem: and he said, Let me go, I pray thee; for our family hath a sacrifice in the city; and my brother, he hath commanded me to be there: and now, if I have found favour in thine eyes, let me get away, I pray thee, and see my brethren. Therefore he cometh not unto the king's table. Then Saul's anger was kindled against Jonathan, and he said unto him, Thou son of the perverse rebellious woman, do not I know that thou hast chosen the son of Jesse to thine own confusion, and unto the confusion of thy mother's nakedness? For as long as the son of Jesse liveth upon the ground, thou shalt not be established, nor thy kingdom. Wherefore now send and fetch him unto me, for he shall surely die. And Jonathan answered Saul his 
father, and said unto him, Wherefore shall he be slain? what hath he done? And Saul cast a javelin at him to smite him: whereby Jonathan knew that it was determined of his father to slay David. So Jonathan arose from the table in fierce anger, and did eat no meat the second day of the month: for he was grieved for David, because his father had done him shame.

And it came to pass in the morning, that Jonathan went out into the field at the time appointed with David, and a little lad with him. And he said unto his lad, Run, find out now the arrows which I shoot. And as the lad ran, he shot an arrow beyond him. And when the lad was come to the place of the arrow which Jonathan had shot, Jonathan cried after the lad, and said, Is not the arrow beyond thee? And Jonathan cried after the lad, Make speed, haste, stay not. And Jonathan's lad gathered up the arrows, and came to his master. But the lad knew not any thing: only Jonathan and David knew the matter. And Jonathan gave his artillery unto his lad, and said unto him, Go, carry them to the city.

And as soon as the lad was gone, David arose out of a place toward the south, and fell on his face to the ground, and bowed himself three times: and they kissed one another, and wept one with another, until David exceeded. And Jonathan said to David, Go in peace, forasmuch as we have sworn both of us in the name of the Lord, saying, The Lord be between me and thee, and between my seed and thy seed for ever. And he arose and departed: and Jonathan went into the city. 


\section{XXXVIII.}

\section{Đavio allo sall.}

I Samuel xxiv.; xxvi.-xxvii. 4.

And it came to pass, when Saul was returned from following the Philistines, that it was told him, saying, Behold, David is in the wilderness of Engedi. Then Saul took three thousand chosen men out of all Israel, and went to seek David and his men upon the rocks of the wild goats. And he came to the sheepcotes by the way, where was a cave; and Saul went in to cover his feet: and David and his men remained in the sides of the cave. And the men of David said unto him, Behold the day of which the Lord said unto thee, Behold, I will deliver thine enemy into thine hand, that thou mayest do to him as it shall seem good unto thee. Then David arose, and cut off the skirt of Saul's robe privily. And it came to pass afterward, that David's heart smote him, because he had cut off Saul's skirt. And he said unto his men, The Lord forbid that I should do this thing unto my master, the Lord's anointed, to stretch forth mine hand against him, seeing he is the anointed of the Lord. So David stayed his servants with these words, and suffered them not to rise against Saul. But Saul rose up out of the cave, and went on his way. David also arose afterward, and went out of the cave, and cried after Saul, saying, My lord the king. And when Saul looked behind him, David 
stooped with his face to the earth, and bowed himself.

And David said to Saul, Wherefore hearest thou men's words, saying, Behold, David seeketh thy hurt? Behold, this day thine eyes have seen how that the Lord had delivered thee to day into mine hand in the cave: and some bade me kill thee: but mine eye spared thee; and I said, I will not put forth mine hand against my lord; for he is the Lord's anointed. Moreover, my father, see, yea, see the skirt of thy robe in my hand: for in that I cut off the skirt of thy robe, and killed thee not, know thou and see that there is neither evil nor transgression in mine hand, and $I$ have not sinned against thee; yet thou huntest my soul to take it. The Lord judge between me and thee, and the Lord avenge me of thee: but mine hand shall not be upon thee. As saith the proverb of the ancients, Wickedness proceedeth from the wicked: but mine hand shall not be upon thee. After whom is the king of Israel come out? after whom dost thou pursue? after a dead dog, after a flea. The Lord therefore be judge, and judge between me and thee, and see, and plead my cause, and deliver me out of thine hand.

And it came to pass, when David had made an end of speaking these words unto Saul, that Saul said, Is this thy voice, my son David? And Saul lifted up his voice, and wept. And he said to David, Thou art more righteous than I: for thou hast rewarded me good, whereas I have rewarded thee evil. And thou hast shewed this day how that thou hast dealt well with me: forasmuch as when 
the Lord had delivered me into thine hand, thou killedst me not. For if a man find his enemy, will he let him go well away? wherefore the Lord reward thee good for that thou hast done unto me this day. And now, behold, I know well that thou shalt surely be king, and that the kingdom of Israel shall be established in thine hand. Swear now therefore unto me by the Lord, that thou wilt not cut off my seed after me, and that thou wilt not destroy my name out of my father's house. And David sware unto Saul. And Saul went home; but David and his men gat them up unto the hold.

And the Ziphites came unto Saul to Gibeah, saying, Doth not David hide himself in the hill of Hachilah, which is before Jeshimon? Then Saul arose, and went down to the wilderness of $\mathrm{Ziph}$, having three thousand chosen men of Israel with him, to seek David in the wilderness of Ziph. And Saul pitched in the hill of Hachilah, which is before Jeshimon, by the way. But David abode in the wilderness, and he saw that Saul came after him into the wilderness. David therefore sent out spies, and understood that Saul was come in very deed. And David arose, and came to the place where Saul had pitched: and David beheld the place where Saul lay, and Abner the son of Ner, the captain of his host: and Saul lay in the trench, and the people pitched round about him. Then answered David and said to Ahimelech the Hittite, and to Abishai the son of Zeruiah, brother to Joab, saying, Who will go down with me to Saul to the camp? And Abishai said, I will go down with thee. So 
David and Abishai came to the people by night: and, behold, Saul lay sleeping within the trench, and his spear stuck in the ground at his bolster: but Abner and the people lay round about him. Then said Abishai to David, God hath delivered thine enemy into thine hand this day: now therefore let me smite him, I pray thee, with the spear even to the earth at once, and I will not smite him the second time. And David said to Abishai, Destroy him not: for who can stretch forth his hand against the Lord's anointed, and be guiltless? David said furthermore, As the Lord liveth, the Lord shall smite him ; or his day shall come to die; or he shall descend into battle, and perish. The Lord forbid that I should stretch forth mine hand against the Lord's anointed: but, I pray thee, take thou now the spear that is at his bolster, and the cruse of water, and let us go. So David took the spear and the cruse of water from Saul's bolster; and they gat them away, and no man saw it, nor knew it, neither awaked: for they were all asleep; because a deep sleep from the Lord was fallen upon them.

Then David went over to the other side, and stood on the top of an hill afar off; a great space being between them: and David cried to the people, and to Abner the son of Ner, saying, Answerest thou not, Abner? Then Abner answered and said, Who art thou that criest to the king? And David said to Abner, Art not thou a valiant man? and who is like to thee in Israel? wherefore then hast thou not kept thy lord the king? for there came one of the people in to destroy the king thy lord. This 
thing is not good that thou hast done. As the Lord liveth, ye are worthy to die, because ye have not kept your master, the Lord's anointed. And now see where the king's spear is, and the cruse of water that was at his bolster. And Saul knew David's voice, and said, Is this thy voice, my son David? And David said, It is my voice, my lord, O king. And he said, Wherefore doth my lord thus pursue after his servant? for what have I done? or what evil is in mine hand? Now therefore, I pray thee, let my lord the king hear the words of his servant. If the Lord have stirred thee up against me, let him accept an offering: but if they be the children of men, cursed be they before the Lord; for they have driven me out this day from abiding in the inheritance of the Lord, saying, Go, serve other gods. Now therefore, let not my blood fall to the earth before the face of the Lord: for the king of Israel is come out to seek a flea, as when one doth hunt a partridge in the mountains.

Then said Saul, I have sinned: return, my son David: for I will no more do thee harm, because my soul was precious in thine eyes this day: behold, I have played the fool, and have erred exceedingly. And David answered and said, Behold the king's spear! and let one of the young men come over and fetch it. The Lord render to every man his righteousness and his faithfulness: for the Lord delivered thee into my hand to day, but I would not stretch forth mine hand against the Lord's anointed. And, behold, as thy life was much set by this day in mine eyes, so let my life be much set by in the eyes of the Lord, and let him deliver me out of all 
tribulation. Then Saul said to David, Blessed be thou, my son David: thou shalt both do great things, and also shalt still prevail. So David went on his way, and Saul returned to his place.

And David said in his heart, I shall now perish one day by the hand of Saul: there is nothing better for me than that I should speedily escape into the land of the Philistines; and Saul shall despair of me, to seek me any more in any coast of Israel: so shall I escape out of his hand. And David arose, and he passed over with the six hundred men that were with him unto Achish, the son of Maoch, king of Gath. And David dwelt with Achish at Gath, he and his men, every man with his household, even David with his two wives, Ahinoam the Jezreelitess, and Abigail the Carmelitess, Nabal's wife. And it was told Saul that David was fled to Gath: and he sought no more again for him.

\section{XXXIX.}

\section{The ruitch of $\mathbb{E} n=00 r$.}

I Samuel xxviii. 3-25; xxxi. I-6.

Now Samuel was dead, and all Israel had lamented him, and buried him in Ramah, even in his own city. And Saul had put away those that had familiar spirits, and the wizards, out of the land. And the Philistines gathered themselves together, and came and pitched in Shunem: and Saul gathered all Israel together, and they pitched in Gilboa. And when Saul saw the host of the Phi- 
listines, he was afraid, and his heart greatly trembled. And when Saul enquired of the Lord, the Lord answered him not, neither by dreams, nor by Urim [i.e. through the high-priest], nor by prophets. Then said Saul unto his servants, Seek me a woman that hath a familiar spirit, that I may go to her, and enquire of her. And his servants said to him, Behold, there is a woman that hath a familiar spirit at En-dor. And Saul disguised himself, and put on other raiment, and he went, and two men with him, and they came to the woman by night: and he said, I pray thee, divine unto me by the familiar spirit, and bring me him up, whom I shall name unto thee. And the woman said unto him, Behold, thou knowest what Saul hath done, how he hath cut off those that have familiar spirits, and the wizards, out of the land: wherefore then layest thou a snare for my life, to cause me to die? And Saul sware to her by the Lord, saying, As the Lord liveth, there shall no punishment happen to thee for this thing. Then said the woman, Whom shall I bring up unto thee? And he said, Bring me up Samuel. And when the woman saw Samuel, she cried with a loud voice: and the woman spake to Saul, saying, Why hast thou deceived me? for thou art Saul. And the king said unto her, Be not afraid: for what sawest thou? And the woman said unto Saul, I saw gods ascending out of the earth. And he said unto her, What form is he of ? And she said, An old man cometh up; and he is covered with a mantle. And Saul perceived that it was Samuel, and he stooped with his face to the ground, and bowed himself. 
And Samuel said to Saul, Why hast thou disquieted me, to bring me up? And Saul answered, I am sore distressed; for the Philistines make war against me, and God is departed from me, and answereth me no more, neither by prophets, nor by dreams: therefore $I$ have called thee, that thou mayest make known unto me what I shall do. Then said Samuel, Wherefore then dost thou ask of me, seeing the Lord is departed from thee, and is become thine enemy? And the Lord hath done to him, as he spake by me: for the Lord hath rent the kingdom out of thine hand, and given it to thy neighbour, even to David: because thou obeyedst not the voice of the Lord, nor executedst his fierce wrath upon Amalek, therefore hath the Lord done this thing unto thee this day. Moreover the Lord will also deliver Israel with thee into the hand of the Philistines: and to morrow shalt thou and thy sons be with me: the Lord also shall deliver the host of Israel into the hand of the Philistines. Then Saul fell straightway all along on the earth, and was sore afraid, because of the words of Samuel: and there was no strength in him; for he had eaten no bread all the day, nor all the night.

And the woman came unto Saul, and saw that he was sore troubled, and said unto him, Behold, thine handmaid hath obeyed thy voice, and I have put my life in my hand, and have hearkened unto thy words which thou spakest unto me. Now therefore, I pray thee, hearken thou also unto the voice of thine handmaid, and let me set a morsel of bread before thee; and eat, that thou mayest have strength, when thou goest on thy way. But he refused, and 
said, I will not eat. But his servants, together with the woman, compelled him; and he hearkened unto their voice. So he rose from the earth, and sat upon the bed. And the woman had a fat calf in the house; and she hasted, and killed it, and took flour, and kneaded it, and did bake unleavened bread thereof: and she brought it before Saul, and before his servants; and they did eat. Then they rose up, and went away that night.

Now the Philistines fought against Israel: and the men of Israel fled from before the Philistines, and fell down slain in mount Gilboa. And the Philistines followed hard upon Saul and upon his sons; and the Philistines slew Jonathan, and Abinadab, and Melchi-shua, Saul's sons. And the battle went sore against Saul, and the archers hit him; and he was sore wounded of the archers. Then said Saul unto his armourbearer, Draw thy sword, and thrust me through therewith; lest these uncircumcised come and thrust me through, and abuse me. But his armourbearer would not; for he was sore afraid. Therefore Saul took a sword, and fell upon it. And when his armourbearer saw that Saul was dead, he fell likewise upon his sword, and died with him. So Saul died, and his three sons, and his armourbearer, and all his men, that same day together. 


\section{XL.}

\section{Đavio and JBatb=sbeba.}

II Samuel xi.-xii. 24.

AND it came to pass, after the year was expired, at the time when kings go forth to battle, that David sent Joab, and his servants with him, and all Israel; and they destroyed the children of Ammon, and besieged Rabbah. But David tarried still at Jerusalem. And it came to pass in an eveningtide, that David arose from off his bed, and walked upon the roof of the king's house : and from the roof he saw a woman washing herself; and the woman was very beautiful to look upon. And David sent and enquired after the woman. And one said, Is not this Bath-sheba, the daughter of Eliam, the wife of Uriah the Hittite? And David sent messengers, and took her; and she came in unto him, and he lay with her; for she was purified from her uncleanness: and she returned unto her house. And the woman conceived, and sent and told David, and said, I am with child.

And David sent to Joab, saying, Send me Uriah the Hittite. And Joab sent Uriah to David. And when Uriah was come unto him, David demanded of him how Joab did, and how the people did, and how the war prospered. And David said to Uriah, Go down to thy house, and wash thy feet. And Uriah departed out of the king's house, and there followed him a mess of meat from the king. But Uriah slept at the door of the king's house with all 
the servants of his lord, and went not down to his house. And when they had told David, saying, Uriah went not down unto his house, David said unto Uriah, Camest thou not from thy journey? why then didst thou not go down unto thine house? And Uriah said unto David, The ark, and Israel, and Judah, abide in tents; and my lord Joab, and the servants of my lord, are encamped in the open fields; shall I then go into mine house, to eat and to drink, and to lie with my wife? as thou livest, and as thy soul liveth, I will not do this thing. And David said to Uriah, Tarry here to day also, and to morrow I will let thee depart. So Uriah abode in Jerusalem that day, and the morrow. And when David had called him, he did eat and drink before him; and he made him drunk: and at even he went out to lie on his bed with the servants of his lord. but went not down to his house.

And it came to pass in the morning, that David wrote a letter to Joab, and sent it by the hand of Uriah. And he wrote in the letter, saying, Set ye Uriah in the forefront of the hottest battle, and retire ye from him, that he may be smitten, and die. And it came to pass, when Joab observed the city, that he assigned Uriah unto a place where he knew that valiant men were. And the men of the city went out, and fought with Joab: and there fell some of the people of the servants of David; and Uriah the Hittite died also.

Then Joab sent and told David all the things concerning the war; and charged the messenger, saying, When thou hast made an end of telling the matters of the war unto the king, and if so be that 
the king's wrath arise, and he say unto thee, Wherefore approached ye so nigh unto the city when ye did fight? knew ye not that they would shoot from the wall? who smote Abimelech the son of Jerubbesheth? did not a woman cast a piece of a millstone upon him from the wall, that he died in Thebez? why went ye nigh the wall? then say thou, Thy servant Uriah the Hittite is dead also.

So the messenger went, and came and shewed David all that Joab had sent him for. And the messenger said unto David, Surely the men prevailed against us, and came out unto us into the field, and we were upon them even unto the entering of the gate. And the shooters shot from off the wall upon thy servants; and some of the king's servants be dead, and thy servant Uriah the Hittite is dead also. Then David said unto the messenger, Thus shalt thou say unto Joab, Let not this thing displease thee, for the sword devoureth one as well as another: make thy battle more strong against the city, and overthrow it: and encourage thou him.

And when the wife of Uriah heard that Uriah her husband was dead, she mourned for her husband. And when the mourning was past, David sent and fetched her to his house, and she became his wife, and bare him a son. But the thing that David had done displeased the Lord.

And the Lord sent Nathan unto David. And he came unto him, and said unto him. There were two men in one city; the one rich, and the other poor. The rich man had exceeding many flocks and herds: but the poor man had nothing, save one little ewe lamb, which he had bought 
and nourished up: and it grew up together with him, and with his children; it did eat of his own meat, and drank of his own cup, and lay in his bosom, and was unto him as a daughter. And there came a traveller unto the rich man, and he spared to take of his own flock and of his own herd, to dress for the wayfaring man that was come unto him; but took the poor man's lamb, and dressed it for the man that was come to him. And David's anger was greatly kindled against the man; and he said to Nathan, As the Lord liveth, the man that hath done this thing shall surely die: and he shall restore the lamb fourfold, because he did this thing, and because he had no pity.

And Nathan said to David, Thou art the man. Thus saith the Lord God of Israel, I anointed thee king over Israel, and I delivered thee out of the hand of Saul; and I gave thee thy master's house, and thy master's wives into thy bosom, and gave thee the house of Israel and of Judah; and if that had been too little, I would moreover have given unto thee such and such things. Wherefore hast thou despised the commandment of the Lord, to do evil in his sight? thou hast killed Uriah the Hittite with the sword, and hast taken his wife to be thy wife, and hast slain him with the sword of the children of Ammon. Now therefore the sword shall never depart from thine house; because thou hast despised me, and hast taken the wife of Uriah the Hittite to be thy wife. Thus saith the Lord, Behold, I will raise up evil against thee out of thine own house, and I will take thy wives before thine eyes, and give them unto thy neighbour, and he 
shall lie with thy wives in the sight of this sun. For thou didst it secretly: but I will do this thing before all Israel, and before the sun. And David said unto Nathan, I have sinned against the Lord. And Nathan said unto David, The Lord also hath put away thy sin; thou shalt not die. Howbeit, because by this deed thou hast given great occasion to the enemies of the Lord to blaspheme, the child also that is born unto thee shall surely die.

And Nathan departed unto his house. And the Lord struck the child that Uriah's wife bare unto David, and it was very sick. David therefore besought God for the child; and David fasted, and went in, and lay all night upon the earth. And the elders of his house arose, and went to him, to raise him up from the earth: but he would not, neither did he eat bread with them. And it came to pass on the seventh day, that the child died. And the servants of David feared to tell him that the child was dead: for they said, Behold, while the child was yet alive, we spake unto him, and he would not hearken unto our voice: how will he then vex himself, if we tell him that the child is dead? But when David saw that his servants whispered, David perceived that the child was dead: therefore David said unto his servants, Is the child dead? And they said, He is dead. Then David arose from the earth, and washed, and anointed himself, and changed his apparel, and came into the house of the Lord, and worshipped: then he came to his own house; and when he required, they set bread before him, and he did eat. Then said his servants unto him, What thing is this that 
thou hast done? thou didst fast and weep for the child, while it was alive; but when the child was dead, thou didst rise and eat bread. And he said, While the child was yet alive, I fasted and wept: for I said, Who can tell whether God will be gracious to me, that the child may live? But now he is dead, wherefore should I fast? can I bring him back again? I shall go to him, but he shall not return to me.

And David comforted Bath-sheba his wife, and went in unto her, and lay with her: and she bare a son, and he called his name Solomon: and the Lord loved him.

\section{XLI.}

\section{The TRevolt of $\mathfrak{A b s a l o m}$.}

II Samuel xviii.

AND David numbered the people that were with him, and set captains of thousands and captains of hundreds over them. And David sent forth a third part of the people under the hand of Joab, and a third part under the hand of Abishai the son of Zeruiah, Joab's brother, and a third part under the hand of Ittai the Gittite. And the king said unto the people, I will surely go forth with you myself also. But the people answered, Thou shalt not go forth: for if we flee away, they will not care for us; neither if half of us die, will they care for us: but now thou art worth ten thousand of us: therefore now it is better that thou succour us out of the city. And the king said unto them, What seemeth 
you best I will do. And the king stood by the gate side, and all the people came out by hundreds and by thousands. And the king commanded Joab and Abishai and Ittai, saying, Deal gently for my sake with the young man, even with Absalom. And all the people heard when the king gave all the captains charge concerning Absalom.

So the people went out into the field against Israel: and the battle was in the wood of Ephraim; where the people of Israel were slain before the servants of David, and there was there a great slaughter that day of twenty thousand men. For the battle was there scattered over the face of all the country: and the wood devoured more people that day than the sword devoured.

And Absalom met the servants of David. And Absalom rocle upon a mule, and the mule went under the thick boughs of a great oak, and his head caught hold of the oak, and he was taken up between the heaven and the earth; and the mule that was under him went away. And a certain man saw it, and told Joab, and said, Behold, I saw Absalom hanged in an oak. And Joab said unto the man that told him, And, behold, thou sawest him, and why didst thou not smite him there to the ground? and I would have given thee ten shekels of silver, and a girdle. And the man said unto Joab, Though I should receive a thousand shekels of silver in mine hand, yet would I not put forth mine hand against the king's son: for in our hearing the king charged thee and Abishai and Ittai, saying, Beware that none touch the young man Absalom. Otherwise I should have wrought false- 
hood against mine own life: for there is no matter hid from the king, and thou thyself wouldest have set thyself against me. Then said Joab, I may not tarry thus with thee. And he took three darts in his hand, and thrust them through the heart of Absalom, while he was yet alive in the midst of the oak. And ten young men that bare Joab's armour compassed about and smote Absalom, and slew him. And Joab blew the trumpet, and the people returned from pursuing after Israel: for Joab held back the people. And they took Absalom, and cast him into a great pit in the wood, and laid a very great heap of stones upon him: and all Israel fled every one to his tent.

Now Absalom in his lifetime had taken and reared up for himself a pillar, which is in the king's dale: for he said, I have no son to keep my name in remembrance: and he called the pillar after his own name: and it is called unto this day, Absalom's place.

Then said Ahimaaz the son of Zadok, Let me now run, and bear the king tidings, how that the Lord hath avenged him of his enemies. And Joab said unto him, Thou shalt not bear tidings this day, but thou shalt bear tidings another day: but this day thou shalt bear no tidings, because the king's son is dead. Then said Joab to Cushi, Go tell the king what thou hast seen. And Cushi bowed himself unto Joab, and ran. Then said Ahimaaz the son of Zadok yet again to Joab, But howsoever, let me, I pray thee, also run after Cushi. And Joab said, Wherefore wilt thou run, my son, seeing that thou hast no ticlings ready? But howsoever, said 
he, let me run. And he said unto him, Run. Then Ahimaaz ran by the way of the plain, and overran Cushi.

And David sat between the two gates: and the watchman went up to the roof over the gate unto the wall, and lifted up his eyes, and looked, and behold a man running alone. And the watchman cried, and told the king. And the king said, If he be alone, there is tidings in his mouth. And he came apace, and drew near. And the watchman saw another man running: and the watchman called unto the porter, and said, Behold another man running alone. And the king said, $\mathrm{He}$ also bringeth tidings. And the watchman said, Methinketh the running of the foremost is like the running of Ahimaaz the son of Zadok. And the king said, $\mathrm{He}$ is a good man, and cometh with good tidings. And Ahimaaz called, and said unto the king, All is well. And he fell down to the earth upon his face before the king, and said, Blessed be the Lord thy God, which hath delivered up the men that lifted up their hand against my lord the king. And the king said, Is the young man Absalom safe? And Ahimaaz answered, When Joab sent the king's servant, and me thy servant, I saw a great tumult, but I knew not what it was. And the king said unto him, Turn aside, and stand here. And he turned aside, and stood still. And, behold, Cushi came; and Cushi said, Tidings, my lord the king: for the Lord hath avenged thee this day of all them that rose up against thee. And the king said unto Cushi, Is the young man Absalom safe? And Cushi answered, The enemies of my lord the king, 
and all that rise against thee to do thee hurt, be as that young man is. And the king was much moved, and went up to the chamber over the gate, and wept: and as he went, thus he said, $O$ my son Absalom, my son, my son Absalom! would God I had died for thee, $\mathrm{O}$ Absalom, my son, my son!

\section{XLII.}

\section{The fllogment of solomon.}

I Kings iii. 5-28.

IN Gibeon the Lord appeared to Solomon in a dream by night: and God said, Ask what I shall give thee. And Solomon said, Thou hast shewed unto thy servant David my father great mercy, according as he walked before thee in truth, and in righteousness, and in uprightness of heart with thee; and thou hast kept for him this great kindness, that thou hast given him a son to sit on his throne, as it is this day. And now, O Lord my God, thou hast made thy servant king instead of David my father: and I am but a little child: I know not how to go out or come in. And thy servant is in the midst of thy people which thou hast chosen, a great people, that cannot be numbered nor counted for multitude. Give therefore thy servant an understanding heart to judge thy people, that I may discern between good and bad: for who is able to judge this thy so great a people?

And the speech pleased the Lord, that Solomon had asked this thing. And God said unto him, 
Because thou hast asked this thing, and hast not asked for thyself long life; neither hast asked riches for thyself, nor hast asked the life of thine enemies; but hast asked for thyself understanding to discern judgment; behold, I have done according to thy words: lo, I have given thee a wise and an understanding heart; so that there was none like thee before thee, neither after thee shall any arise like unto thee. And I have also given thee that which thou hast not asked, both riches, and honour: so that there shall not be any among the kings like unto thee all thy days. And if thou wilt walk in my ways, to keep my statutes and my commandments, as thy father David did walk, then I will lengthen thy days. And Solomon awoke; and, behold, it was a dream. And he came to Jerusalem, and stood before the ark of the covenant of the Lord, and offered up burnt offerings, and offered peace offerings, and made a feast to all his servants.

Then came there two women, that were harlots, unto the king, and stood before him. And the one woman said, O my lord, I and this woman dwell in one house; and I was delivered of a child with her in the house. And it came to pass the third day after that I was delivered, that this woman was delivered also: and we were together; there was no stranger with us in the house, save we two in the house. And this woman's child died in the night; because she overlaid it. And she arose at midnight, and took my son from beside me, while thine handmaid slept, and laid it in her bosom, and laid her dead child in my bosom. And when I rose in the morning to give my child suck, behold, 
it was dead: but when I had considered it in the morning, behold, it was not my son, which I did bear. And the other woman said, Nay; but the living is my son, and the dead is thy son. And this said, No; but the dead is thy son, and the living is my son. Thus they spake before the king. Then said the king, The one saith, This is my son that liveth, and thy son is the dead: and the other saith, Nay; but thy son is the dead, and my son is the living. And the king said, Bring me a sword. And they brought a sword before the king. And the king said, Divide the living child in two, and give half to the one, and half to the other. Then spake the woman whose the living child was unto the king, for her bowels yearned upon her son, and she said, $O$ my lord, give her the living child, and in no wise slay it. But the other said, Let it be neither mine nor thine, but divide it. Then the king answered and said, Give her the living child, and in no wise slay it: she is the mother thereof. And all Israel heard of the judgment which the king had judged; and they feared the king: for they saw that the wisdom of God was in him, to do judgment.

\section{XLIII.}

\section{The Queen of झheba.}

I Kings $\mathrm{x}$. I-I3.

And when the queen of Sheba heard of the fame of Solomon concerning the name of the Lord, she came to prove him with hard questions. And she 
came to Jerusalem with a very great train, with camels that bare spices, and very much gold, and precious stones: and when she was come to Solomon, she communed with him of all that was in her heart. And Solomon told her all her questions: there was not any thing hid from the king, which he told her not. And when the queen of Sheba had seen all Solomon's wisdom, and the house that he had built, and the meat of his table, and the sitting of his servants, and the attendance of his ministers, and their apparel, and his cupbearers, and his ascent by which he went up unto the house of the Lord; there was no more spirit in her. And she said to the king, It was a true report that I heard in mine own land of thy acts and of thy wisdom. Howbeit I believed not the words, until I came, and mine eyes had seen it: and, behold, the half was not told me: thy wisdom and prosperity exceedeth the fame which I heard. Happy are thy men, happy are these thy servants, which stand continually before thee, and that hear thy wisdom. Blessed be the Lord thy God, which delighted in thee, to set thee on the throne of Israel: because the Lord loved Israel for ever, therefore made he thee king, to do judgment and justice. And she gave the king an hundred and twenty talents of gold, and of spices very great store, and precious stones: there came no more such abundance of spices as these which the queen of Sheba gave to king Solomon. And the navy also of Hiram, that brought gold from Ophir, brought in from Ophir great plenty of almug trees, and precious stones. And the king made of the almug trees pillars for 
the house of the Lord, and for the king's house, harps also and psalteries for singers: there came no such almug trees, nor were seen unto this day. And king Solomon gave unto the queen of Sheba all her desire, whatsoever she asked, besides that which Solomon gave her of his royal bounty. So she turned and went to her own country, she and her servants.

\section{XLIV.}

\section{Reboboam and Feroboam.}

I Kings xi. 4-13; xi. 26-xii. 20.

For it came to pass, when Solomon was old, that his wives turned away his heart after other gods: and his heart was not perfect with the Lord his God, as was the heart of David his father. For Solomon went after Ashtoreth the goddess of the Zidonians, and after Milcom the abomination of the Ammonites. And Solomon did evil in the sight of the Lord, and went not fully after the Lord, as did David his father. Then did Solomon build an high place for Chemosh, the abomination of Moab, in the hill that is before Jerusalem, and for Molech, the abomination of the children of Ammon. And likewise did he for all his strange wives, which burnt incense and sacrificed unto their gods.

And the Lord was angry with Solomon, because his heart was turned from the Lord God of Israel, which had appeared unto him twice, and had commanded him concerning this thing, that he should not go after other gods: but he kept not that which 
the Lord commanded. Wherefore the Lord said unto Solomon, Forasmuch as this is done of thee, and thou hast not kept my covenant and my statutes, which I have commanded thee, I will surely rend the kingdom from thee, and will give it to thy servant. Notwithstanding in thy days I will not do it for David thy father's sake: but I will rend it out of the hand of thy son. Howbeit I will not rend away all the kingdom; but will give one tribe to thy son for David my servant's sake, and for Jerusalem's sake which I have chosen.

And Jeroboam the son of Nebat, an Ephrathite of Zereda, Solomon's servant, whose mother's name was Zeruah, a widow woman, even he lifted up his hand against the king. And this was the cause that he lifted up his hand against the king: Solomon built Millo, and repaired the breaches of the city of David his father. And the man Jeroboam was a mighty man of valour: and Solomon seeing the young man that he was industrious, he made him ruler over all the charge of the house of Joseph.

And it came to pass at that time when Jeroboam went out of Jerusalem, that the prophet Ahijah the Shilonite found him in the way; and he had clad himself with a new garment; and they two were alone in the field: and Ahijah caught the new garment that was on him, and rent it in twelve pieces: and he said to Jeroboam, Take thee ten pieces: for thus saith the Lord, the God of Israel, Behold, I will rend the kingdom out of the hand of Solomon, and will give ten tribes to thee: (but he shall have 
one tribe for my servant David's sake, and for Jerusalem's sake, the city which I have chosen out of all the tribes of Israel:) because that they have forsaken me, and have worshipped Ashtoreth the goddess of the Zidonians, Chemosh the god of the Moabites, and Milcom the god of the children of Ammon, and have not walked in my ways, to do that which is right in mine eyes, and to keep my statutes and my judgments, as did David his father. Howbeit I will not take the whole kingdom out of his hand: but I will make him prince all the days of his life for David my servant's sake, whom I chose, because he kept my commandments and my statutes: but I will take the kingdom out of his son's hand, and will give it unto thee, even ten tribes. And unto his son will I give one tribe, that David my servant may have a light alway before me in Jerusalem, the city which I have chosen me to put my name there. And I will take thee, and thou shalt reign according to all that thy soul desireth, and shalt be king over Israel. And it shall be, if thou wilt hearken unto all that I command thee, and wilt walk in my ways, and do that is right in my sight, to keep my statutes and my commandments, as David my servant did; that I will be with thee, and build thee a sure house, as I built for David, and will give Israel unto thee. And I will for this afflict the seed of David, but not for ever. Solomon sought therefore to kill Jeroboam. And Jeroboam arose, and fled into Egypt, unto Shishak king of Egypt, and was in Egypt until the death of Solomon.

And the rest of the acts of Solomon, and all that 
he did, and his wisdom, are they not written in the book of the acts of Solomon? And the time that Solomon reigned in Jerusalem over all Israel was forty years. And Solomon slept with his fathers, and was buried in the city of David his father: and Rehoboam his son reigned in his stead.

And Rehoboam went to Shechem: for all Israel were come to Shechem to make him king. And it came to pass, when Jeroboam the son of Nebat, who was yet in Egypt, heard of it, (for he was fled from the presence of king Solomon, and Jeroboam dwelt in Egypt;) that they sent and called him. And Jeroboam and all the congregation of Israel came, and spake unto Rehoboam, saying, Thy father made our yoke grievous: now therefore make thou the grievous service of thy father, and his heavy yoke which he put upon us, lighter, and we will serve thee. And he said unto them, Depart yet for three days, then come again to me. And the people departed.

And king Rehoboam consulted with the old men, that stood before Solomon his father while he yet lived, and said, How do ye advise that I may answer this people? And they spake unto him, saying, If thou wilt be a servant unto this people this day, and wilt serve them, and answer them, and speak good words to them, then they will be thy servants for ever. But he forsook the counsel of the old men, which they had given him, and consulted with the young men that were grown up with him, and which stood before him: and he said unto them, What counsel give ye that we may answer this people, who have spoken to me, saying, Make the 
yoke which thy father did put upon us lighter? And the young men that were grown up with him spake unto him, saying, Thus shalt thou speak unto this people that spake unto thee, saying, Thy father made our yoke heavy, but make thou it lighter unto us; thus shalt thou say unto them, My little finger shall be thicker than my father's loins. And now whereas my father did lade you with a heavy yoke, I will add to your yoke: my father hath chastised you with whips, but I will chastise you with scorpions.

So Jeroboam and all the people came to Rehoboam the third day, as the king had appointed, saying, Come to me again the third day. And the king answered the people roughly, and forsook the old men's counsel that they gave him; and spake to them after the counsel of the young men, saying, My father made your yoke heavy, and I will add to your yoke: my father also chastised you with whips, but I will chastise you with scorpions. Wherefore the king hearkened not unto the people; for the cause was from the Lord, that he might perform his saying, which the Lord spake by Ahijah the Shilonite unto Jeroboam the son of Nebat.

So when all Israel saw that the king hearkened not unto them, the people answered the king, saying, What portion have we in David? neither have we inheritance in the son of Jesse: to your tents, O Israel: now see to thine own house, David. So Israel departed unto their tents. But as for the children of Israel which dwelt in the cities of Judah, Rehoboam reigned over them. Then king Rehoboam sent Adoram, who was over the tribute; 
and all Israel stoned him with stones, that he died. Therefore king Rehoboam made speed to get him up to his chariot, to flee to Jerusalem. So Israel rebelled against the house of David unto this day. And it came to pass, when all Israel heard that Jeroboam was come again, that they sent and called him unto the congregation, and made him king over all Israel: there was none that followed the house of David, but the tribe of Judah only.

\section{XLV.}

\section{Elíjab.}

I Kings xvi. 29-33; xvii. I-I6; xviii. I-2; xviii. I7-xix.

AND in the thirty and eighth year of Asa king of Judah began Ahab the son of Omri to reign over Israel: and Ahab the son of Omri reigned over Israel in Samaria twenty and two years. And Ahab the son of Omri did evil in the sight of the Lord above all that were before him. And it came to pass, as if it had been a light thing for him to walk in the sins of Jeroboam the son of Nebat, that he took to wife Jezebel the daughter of Ethbaal king of the Zidonians, and went and served Baal, and worshipped him. And he reared up an altar for Baal in the house of Baal, which he had built in Samaria. And Ahab made a grove; and Ahab did more to provoke the Lord God of Israel to anger than all the kings of Israel that were before him. 
And Elijah the Tishbite, who was of the inhabitants of Gilead, said unto Ahab, As the Lord God of Israel liveth, before whom I stand, there shall not be dew nor rain these years, but according to my word. And the word of the Lord came unto him, saying, Get thee hence, and turn thee eastward, and hide thyself by the brook Cherith, that is before Jordan. And it shall be, that thou shalt drink of the brook; and I have commanded the ravens to feed thee there. So he went and did according unto the word of the Lord: for he went and dwelt by the brook Cherith, that is before Jordan. And the ravens brought him bread and flesh in the morning, and bread and flesh in the evening; and he drank of the brook. And it came to pass after a while, that the brook dried up, because there had been no rain in the land.

And the word of the Lord came unto him, saying, Arise, get thee to Zarephath, which belongeth to Zidon, and dwell there: behold, I have commanded a widow woman there to sustain thee. So he arose and went to Zarephath. And when he came to the gate of the city, behold, the widow woman was there gathering of sticks: and he called to her, and said, Fetch me, I pray thee, a little water in a vessel, that I may drink. And as she was going to fetch it, he called to her, and said, Bring me, I pray thee, a morsel of bread in thine hand. And she said, As the Lord thy God liveth, I have not a cake, but an handful of meal in a barrel, and a little oil in a cruse: and, behold, I am gathering two sticks, that I may go in and dress it for me and my son, that we may eat it, and die. And Elijah said unto her, 
Fear not; go and do as thou hast said: but make me thereof a little cake first, and bring it unto me, and after make for thee and for thy son. For thus saith the Lord God of Israel, The barrel of meal shall not waste, neither shall the cruse of oil fail, until the day that the Lord sendeth rain upon the earth. And she went and did according to the saying of Elijah: and she, and he, and her house, did eat many days. And the barrel of meal wasted not, neither did the cruse of oil fail, according to the word of the Lord, which he spake by Elijah.

And it came to pass after many days, that the word of the Lord came to Elijah in the third year, saying, Go, shew thyself unto Ahab; and I will send rain upon the earth. And Elijah went to shew himself unto Ahab. And there was a sore famine in Samaria.

And it came to pass, when Ahab saw Elijah, that Ahab said unto him, Art thou he that troubleth Israel? And he answered, I have not troubled Israel; but thou, and thy father's house, in that ye have forsaken the commandments of the Lord, and thou hast followed Baalim. Now therefore send, and gather to me all Israel unto mount Carmel, and the prophets of Baal four hundred and fifty, and the prophets of the groves four hundred, which eat at Jezebel's table. So Ahab sent unto all the children of Israel, and gathered the prophets together unto mount Carmel.

And Elijah came unto all the people, and said, How long halt ye between two opinions? if the 
Lord be God, follow him: but if Baal, then follow him. And the people answered him not a word. Then said Elijah unto the people, I, even I only, remain a prophet of the Lord; but Baal's prophets are four hundred and fifty men. Let them therefore give us two bullocks; and let them choose one bullock for themselves, and cut it in pieces, and lay it on wood, and put no fire under: and I will dress the other bullock, and lay it on wood, and put no fire under: and call ye on the name of your gods, and I will call on the name of the Lord: and the God that answereth by fire, let him be God. And all the people answered and said, It is well spoken. And Elijah said unto the prophets of Baal, Choose you one bullock for yourselves, and dress it first; for ye are many; and call on the name of your gods, but put no fire under. And they took the bullock which was given them, and they dressed it, and called on the name of Baal from morning even until noon, saying, O Baal, hear us. But there was no voice, nor any that answered. And they leaped upon the altar which was made. And it came to pass at noon, that Elijah mocked them, and said, Cry aloud: for he is a god; either he is talking, or he is pursuing, or he is in a journey, or peradventure he sleepeth, and must be awaked. And they cried aloud, and cut themselves after their manner with knives and lancets, till the blood gushed out upon them. And it came to pass, when midday was past, and they prophesied until the time of the offering of the evening sacrifice, that there was neither voice, nor any to answer, nor any that regarded. 
And Elijah said unto all the people, Come near unto me. And all the people came near unto him. And he repaired the altar of the Lord that was broken down. And Elijah took twelve stones, according to the number of the tribes of the sons of Jacob, unto whom the word of the Lord came, saying, Israel shall be thy name: and with the stones he built an altar in the name of the Lord: and he made a trench about the altar, as great as would contain two measures of seed. And he put the wood in order, and cut the bullock in pieces, and laid him on the wood, and said, Fill four barrels with water, and pour it on the burnt sacrifice, and on the wood. And he said, Do it the second time. And they did it the second time. And he said, Do it the third time. And they did it the third time. And the water ran round about the altar; and he filled the trench also with water.

And it came to pass at the time of the offering of the evening sacrifice, that Elijah the prophet came near, and said, Lord God of Abraham, Isaac, and of Israel, let it be known this day that thou art God in Israel, and that I am thy servant, and that $I$ have done all these things at thy word. Hear me, O Lord, hear me, that this people may know that thou art the Lord God, and that thou hast turned their heart back again. Then the fire of the Lord fell, and consumed the burnt sacrifice, and the wood, and the stones, and the dust, and licked up the water that was in the trench. And when all the people saw it, they fell on their faces; and they said, The Lord, he is the God; the Lord, he is the God. And Elijah said unto them, 
Take the prophets of Baal; let not one of them escape. And they took them: and Elijah brought them down to the brook. Kishon, and slew them there.

And Elijah said unto Ahab, Get thee up, eat and drink; for there is a sound of abundance of rain. So Ahab went up to eat and to drink. And Elijah went up to the top of Carmel; and he cast himself down upon the earth, and put his face between his knees, and said to his servant, Go up now, look toward the sea. And he went up, and looked, and said, There is nothing. And he said, Go again seven times. And it came to pass at the seventh time, that he said, Behold, there ariseth a little cloud out of the sea, like a man's hand. And he said, Go up, say unto Ahab, Prepare thy chariot, and get thee down, that the rain stop thee not. And it came to pass in the mean while, that the heaven was black with clouds and wind, and there was a great rain. And Ahab rode, and went to Jezreel. And the hand of the Lord was on Elijah; and he girded up his loins, and ran before Ahab to the entrance of Jezreel.

And Ahab told Jezebel all that Elijah had done, and withal how he had slain all the prophets with the sword. Then Jezebel sent a messenger unto Elijah, saying, So let the gods do to me, and more also, if I make not thy life as the life of one of them by to morrow about this time. And when he saw that, he arose, and went for his life, and came to Beer-sheba, which belongeth to Judah, and left his servant there.

But he himself went a day's journey into the 
wilderness, and came and sat down under a juniper tree: and he requested for himself that he might die; and said, It is enough; now, O Lord, take away my life; for I am not better than my fathers. And as he lay and slept under a juniper tree, behold, then an angel touched him, and said unto him, Arise and eat. And he looked, and, behold, there was a cake baken on the coals, and a cruse of water at his head. And he did eat and drink, and laid him down again. And the angel of the Lord came again the second time, and touched him, and said, Arise and eat; because the journey is too great for thee. And he arose, and did eat and drink, and went in the strength of that meat forty days and forty nights unto Horeb the mount of God.

And he came thither unto a cave, and lodged there; and, behold, the word of the Lord came to him, and he said unto him, What doest thou here, Elijah? And he said, I have been very jealous for the Lord God of hosts: for the children of Israel have forsaken thy covenant, thrown down thine altars, and slain thy prophets with the sword; and I, even I only, am left; and they seek my life, to take it away. And he said, Go forth, and stand upon the mount before the Lord. And, behold, the Lord passed by, and a great and strong wind rent the mountains, and brake in pieces the rocks before the Lord; but the Lord was not in the wind: and after the wind an earthquake; but the Lord was not in the earthquake: and after the earthquake a fire; but the Lord was not in the fire: and after the fire a still small voice. And it was so, when 
Elijah heard it, that he wrapped his face in his mantle, and went out, and stood in the entering in of the cave. And, behold, there came a voice unto him, and said, What doest thou here, Elijah? And he said, I have been very jealous for the Lord God of hosts: because the children of Israel have forsaken thy covenant, thrown down thine altars, and slain thy prophets with the sword; and I, even I only, am left; and they seek my life, to take it away. And the Lord said unto him, Go, return on thy way to the wilderness of Damascus: and when thou comest, anoint Hazael to be king over Syria: and Jehu the son of Nimshi shalt thou anoint to be king over Israel: and Elisha the son of Shaphat of Abel-meholah shalt thou anoint to be prophet in thy room. And it shall come to pass, that him that escapeth the sword of Hazael shall Jehu slay: and him that escapeth from the sword of Jehu shall Elisha slay. Yet I have left me seven thousand in Israel, all the knees which have not bowed unto Baal, and every mouth which hath not kissed him.

So he departed thence, and found Elisha the son of Shaphat, who was plowing with twelve yoke of oxen before him, and he with the twelfth: and Elijah passed by him, and cast his mantle upon him. And he left the oxen, and ran after Elijah, and said, Let me, I pray thee, kiss my father and my mother, and then I will follow thee. And he said unto him, Go back again: for what have I done to thee? And he returned back from him, and took a yoke of oxen, and slew them, and boiled their flesh with the instruments of the oxen, and 
gave unto the people, and they did eat. Then he arose, and went after Elijah, and ministered unto him.

\section{XLVI.}

\section{Thabotb's Uincyard.}

I Kings xxi.

And it came to pass after these things, that Naboth the Jezreelite had a vineyard, which was in Jezreel, hard by the palace of Ahab king of Samaria. And Ahab spake unto Naboth, saying, Give me thy vineyard, that I may have it for a garden of herbs, because it is near unto my house: and I will give thee for it a better vineyard than it; or, if it seem good to thee, I will give thee the worth of it in money. And Naboth said to Ahab, The Lord forbid it me, that I should give the inheritance of my fathers unto thee. And Ahab came into his house heavy and displeased because of the word which Naboth the Jezreelite had spoken to him: for he had said, I will not give thee the inheritance of my fathers. And he laid him down upon his bed, and turned away his face, and would eat no bread.

But Jezebel his wife came to him, and said unto him, Why is thy spirit so sad, that thou eatest no bread? And he said unto her, Because I spake unto Naboth the Jezreelite, and said unto him, Give me thy vineyard for money; or else, if it please thee, I will give thee another vineyard for it: and he answered, I will not give thee my vineyard. 
And Jezebel his wife said unto him, Dost thou now govern the kingdom of Israel? arise, and eat bread, and let thine heart be merry: I will give thee the vineyard of Naboth the Jezreelite. So she wrote letters in. Ahab's name, and sealed them with his seal, and sent the letters unto the elders and to the nobles that were in his city, dwelling with Naboth. And she wrote in the letters, saying, Proclaim a fast, and set Naboth on high among the people: and set two men, sons of Belial, before him, to bear witness against him, saying, Thou didst blaspheme God and the king. And then carry him out, and stone him, that he may die.

And the men of his city, even the elders and the nobles who were the inhabitants in his city, did as Jezebel had sent unto them, and as it was written in the letters which she had sent unto them. They proclained a fast, and set Naboth on high among the people. And there came in two men, children of Belial, and sat before him: and the men of Belial witnessed against him, even against Naboth, in the presence of the people, saying, Naboth did blaspheme God and the king. Then they carried him forth out of the eity, and stoned him with stones, that he died. Then they sent to Jezebel, saying, Naboth is stoned, and is dead.

And it came to pass, when Jezebel heard that Naboth was stoned, and was lead, that Jezebel said to Ahab, Arise, take possession of the vineyard of Naboth the Jezreelite, which he refused to give thee for money: for Naboth is not alive, but dead. And it came to pass, when Ahab heard that Naboth was dead, that Ahab rose up to go down to the 
vineyard of Naboth the Jezreelite, to take possession of it.

And the word of the Lord came to Elijah the Tishbite, saying, Arise, go down to meet Ahab king of Israel, which is in Samaria: behold, he is in the vineyard of Naboth, whither he is gone down to possess it. And thou shalt speak unto him, saying, Thus saith the Lord, Hast thou killed, and also taken possession? And thou shalt speak unto him, saying, Thus saith the Lord, In the place where dogs licked the blood of Naboth shall dogs lick thy blood, even thine. And Ahab said to Elijah, Hast thou found me, $\mathrm{O}$ mine enemy? And he answered, I have found thee: because thou hast sold thyself to work evil in the sight of the Lord. Behold, I will bring evil upon thee, and will take away thy posterity, and will cut off from Ahab him that pisseth against the wall, and him that is shut up and left in Israel, and will make thine house like the house of Jeroboam the son of Nebat, and like the house of Baasha the son of Ahijah, for the provocation wherewith thou hast provoked me to anger, and made Israel to sin. And of Jezebel also spake the Lord, saying, The dogs shall eat Jezebel by the wall of Jezreel. Him that dieth of Ahab in the city the dogs shall eat; and him that dieth in the field shall the fowls of the air eat.

But there was none like unto Ahab, which did sell himself to work wickedness in the sight of the Lord, whom Jezebel his wife stirred up. And he did very abominably in following idols, according to all things as did the Amorites, whom the Lord cast out before the children of Israel. 
And it came to pass, when Ahab heard those words, that he rent his clothes, and put sackcloth upon his flesh, and fasted, and lay in sackcloth, and went softly. And the word of the Lord came to Elijah the Tishbite, saying, Seest thou how Ahab humbleth himself before me? because he humbleth himself before me, I will not bring the evil in his days: but in his son's days will I bring the evil upon his house.

\section{XLVII.}

\section{The Deatb of $\mathfrak{A}$ bab.}

\section{Kings xxii. 29-40.}

So the king of Israel and Jehoshaphat the king of Judah went up to Ramoth-gilead. And the king of Israel said unto Jehoshaphat, I will disguise myself, and enter into the battle; but put thou on thy robes. And the king of Israel disguised himself, and went into the battle. But the king of Syria commanded his thirty and two captains that had rule over his chariots, saying, Fight neither with small nor great, save only with the king of Israel. And it came to pass, when the captains of the chariots saw Jehoshaphat, that they said, Surely it is the king of Israel. And they turned aside to fight against him: and Jehoshaphat cried out. And it came to pass, when the captains of the chariots perceived that it was not the king of Israel, that they turned back from pursuing him. And a certain man drew a bow at a venture, and smote the king of Israel between the joints of the harness: wherefore he said unto the driver of his chariot, 
Turn thine hand, and carry me out of the host; for I am wounded. And the battle increased that day: and the king was stayed up in his chariot against the Syrians, and died at even: and the blood ran out of the wound into the midst of the chariot. And there went a proclamation throughout the host about the going down of the sun, saying, Every man to his city, and every man to his own country. So the king died, and was brought to Samaria; and they buried the king in Samaria. And one washed the chariot in the pool of Samaria; and the dogs licked up his blood; and they washed his armour; according unto the word of the Lord which he spake.

Now the rest of the acts of Ahab, and all that he did, and the ivory house which he made, and all the cities that he built, are they not written in the book of the chronicles of the kings of Israel? So Ahab slept with his fathers; and Ahaziah his son reigned in his stead.

\section{XLVIII.}

\section{Tbe Translation of Elfjab.}

II Kings ii.

AND it came to pass, when the Lord would take up Elijah into heaven by a whirlwind, that Elijah went with Elisha from Gilgal. And Elijah said unto Elisha, Tarry here, I pray thee; for the Lord hath sent me to Beth-el. And Elisha said unto him, As the Lord liveth, and as thy soul liveth, I will not leave thee. So they went down to Beth-el. 
And the sons of the prophets that were at Beth-el came forth to Elisha, and said unto him, Knowest thou that the Lord will take away thy master from thy head to day? And he said, Yea, I know it; hold ye your peace. And Elijah said unto him, Elisha, tarry here, I pray thee; for the Lord hath sent me to Jericho. And he said, As the Lord liveth, and as thy soul liveth, I will not leave thee. So they came to Jericho. And the sons of the prophets that were at Jericho came to Elisha, and said unto him, Knowest thou that the Lord will take away thy master from thy head to day? And he answered, Yea, I know it; hold ye your peace. And Elijah said unto him, Tarry, I pray thee, here; for the Lord hath sent me to Jordan. And he said, As the Lord liveth, and as thy soul liveth, I will not leave thee. And they two went on. And fifty men of the sons of the prophets went, and stood to view afar off: and they two stood by Jordan. And Elijah took his mantle, and wrapped it together, and smote the waters, and they were divided hither and thither, so that they two went over on dry ground.

And it came to pass, when they were gone over, that Elijah said unto Elisha, Ask what I shall do for thee, before I be taken away from thee. And Elisha said, I pray thee, let a double portion of thy spirit be upon me. And he said, Thou hast asked a hard thing: nevertheless, if thou see me when I am taken from thee, it shall be so unto thee; but if not, it shall not be so. And it came to pass, as they still went on, and talked, that, behold, there appeared a chariot of fire, and horses of fire, and 
parted them both asunder; and Elijah went up by a whirlwind into heaven.

And Elisha saw it, and he cried, My father, my father, the chariot of Israel, and the horsemen thereof. And he saw him no more: and he took hold of his own clothes, and rent them in two pieces. He took up also the mantle of Elijah that fell from him, and went back, and stood by the bank of Jordan; and he took the mantle of Elijah that fell from hins, and smote the waters, and said, Where is the Lord God of Elijah? And when he also had smitten the waters, they parted hither and thither: and Elisha went over.

And when the sons of the prophets which were to view at Jericho saw him, they said, The spirit of Elijah doth rest on Elisha. And they came to meet him, and bowed themselves to the ground before him. And they said unto him, Behold now, there be with thy servants fifty strong men; let them go, we pray thee, and seek thy master: lest peradventure the Spirit of the Lord hath taken him up, and cast him upon some mountain, or into some valley. And he said, Ye shall not send. And when they urged him till he was ashamed, he said, Send. They sent therefore fifty men; and they sought three days, but found him not. And when they came again to him, (for he tarried at Jericho, ) he said unto them, Did I not say unto you, Go not? And the men of the city said unto Elisha, Behold, I pray thee, the situation of this city is pleasant, as my lord seeth: but the water is naught, and the ground barren. And he said, Bring me a new cruse, and put salt therein. And they brought it 
to him. And he went forth unto the spring of the waters, and cast the salt in there, and said, Thus saith the Lord, I have healed these waters; there shall not be from thence any more death or barren land. So the waters were healed unto this day, according to the saying of Elisha which he spake.

And he went up from thence unto Beth-el: and as he was going up by the way, there came forth little children out of the city, and mocked him, and said unto him, Go up, thou bald head; go up, thou bald head. And he turned back, and looked on them, and cursed them in the name of the Lord. And there came forth two she bears out of the wood, and tare forty and two children of them. And he went from thence to mount Carmel, and from thence he returned to Samaria.

\section{XLIX.}

\section{Elísba.}

II Kings iv. I-37.

Now there cried a certain woman of the wives of the sons of the prophets unto Elisha, saying, Thy servant my husband is dead; and thou knowest that thy servant did fear the Lord: and the creditor is come to take unto him my two sons to be bondmen. And Elisha said unto her, What shall I do for thee? tell me, what hast thou in the house? And she said, Thine handmaid hath not any thing in the house, save a pot of oil. Then he said, Go borrow thee vessels abroad of all thy neighbours, 
even empty vessels; borrow not a few. And when thou art come in, thou shalt shut the door upon thee and upon thy sons, and shalt pour out into all those vessels, and thou shalt set aside that which is full. So she went from him, and shut the door upon her and upon her sons, who brought the vessels to her; and she poured out. And it came to pass, when the vessels were full, that she said unto her son, Bring me yet a vessel. And he said unto her, There is not a vessel more. And the oil stayed. Then she came and told the man of God. And he said, Go, sell the oil, and pay thy debt, and live thou and thy children of the rest.

And it fell on a day, that Elisha passed to Shunem, where was a great woman; and she constrained him to eat bread. And so it was, that as oft as he passed by, he turned in thither to eat bread. And she said unto her husband, Behold now, I perceive that this is an holy man of God, which passeth by us continually. Let us make a little chamber, I pray thee, on the wall; and let us set for him there a bed, and a table, and a stool, and a candlestick: and it shall be, when he cometh to us, that he shall turn in thither.

And it fell on a day, that he came thither, and he turned into the chamber, and lay there. And he said to Gehazi his servant, Call this Shunammite. And when he had called her, she stood before him. And he said unto him, Say now unto her, Behold, thou hast been careful for us with all this care; what is to be done for thee? wouldest thou be spoken for to the king, or to the captain of the host? And she answered, I dwell among mine own 
people. And he said, What then is to be done for her? And Gehazi answered, Verily she hath no child, and her husband is old. And he said, Call her. And when he had called her, she stood in the door. And he said, About this season, according to the time of life, thou shalt embrace a son. And she said, Nay, my lord, thou man of God, do not lie unto thine handmaid. And the woman conceived, and bare a son at that season that Elisha had said unto her, according to the time of life.

And when the child was grown, it fell on a day, that he went out to his father to the reapers. And he said unto his father, My head, my head. And he said to a lad, Carry him to his mother. And when he had taken him, and brought him to his mother, he sat on her knees till noon, and then died. And she went up, and laid him on the bed of the man of God, and shut the door upon him, and went out. And she called unto her husband, and said, Send me, I pray thee, one of the young men, and one of the asses, that I may run to the man of God, and come again. And he said, Wherefore wilt thou go to him to day? it is neither new moon, nor sabbath. And she said, It shall be well. Then she saddled an ass, and said to her servant, Drive, and go forward; slack not thy riding for me, except I bid thee. So she went and came unto the man of God to mount Carmel. And it came to pass, when the man of God saw her afar off, that he said to Gehazi his servant, Behold, yonder is that Shunammite: run now, I pray thee, to meet her, and say unto her, Is it well with thee? is it well with thy husband? is it well with the child? And she 
answered, It is well. And when she came to the man of God to the hill, she caught him by the feet: but Gehazi came near to thrust her away. And the man of God said, Let her alone; for her soul is vexed within her: and the Lord hath hid it from me, and hath not told me. Then she said, Did I desire a son of my lord? did I not say, Do not deceive me? Then he said to Gehazi, Gird up thy loins, and take my staff in thine hand, and go thy way: if thou meet any man, salute him not; and if any salute thee, answer him not again: and lay my staff upon the face of the child. And the mother of the child said, As the Lord liveth, and as thy soul liveth, I will not leave thee. And he arose, and followed her.

And Gehazi passed on before them, and laid the staff upon the face of the child; but there was neither voice, nor hearing. Wherefore he went again to meet him, and told him, saying, The child is not awaked. And when Elisha was come into the house, behold, the child was dead, and laid upon his bed. He went in therefore, and shut the door upon them twain, and prayed unto the Lord. And he went up, and lay upon the child, and put his mouth upon his mouth, and his eyes upon his eyes, and his hands upon his hands: and he stretched himself upon the child; and the flesh of the child waxed warm. Then he returned, and walked in the house to and fro; and went up, and stretched himself upon him: and the child sneezed seven times, and the child opened his eyes. And he called Gehazi, and said, Call this Shunammite. So he called her. And when she was come in unto him, he said, Take up 
thy son. Then she went in, and fell at his feet, and bowed herself to the ground, and took up her son, and went out.

\section{L.}

Raaman, the $\mathfrak{L} e$ per.

II Kings v.

Now Naaman, captain of the host of the king of Syria, was a great man with his master, and honourable, because by him the Lord had given deliverance unto Syria: he was also a mighty man in valour, but he was a leper. And the Syrians had gone out by companies, and had brought away captive out of the land of Israel a little maid; and she waited on Naaman's wife. And she said unto her mistress, Would God my lord were with the prophet that is in Samaria! for he would recover him of his leprosy. And one went in, and told his lord, saying, Thus and thus said the maid that is of the land of Israel. And the king of Syria said, Go to; go, and I will send a letter unto the king of Israel. And he departed, and took with him ten talents of silver, and six thousand pieces of gold, and ten changes of raiment. And he brought the letter to the king of Israel, saying, Now when this letter is come unto thee, behold, I have therewith sent Naaman my servant to thee, that thou mayest recover him of his leprosy. And it came to pass, when the king of Israel had read the letter, that he rent his clothes, and said, Am I God, to kill and to make alive, that this man loth send unto me to 
recover a man of his leprosy? Wherefore consider, I pray you, and see how he seeketh a quarrel against me.

And it was so, when Elisha the man of God had heard that the king of Israel had rent his clothes, that he sent to the king, saying, Wherefore hast thou rent thy clothes? let him come now to me, and he shall know that there is a prophet in Israel. So Naaman came with his horses and with his chariot, and stood at the door of the house of Elisha. And Elisha sent a messenger unto him, saying, Go and wash in Jordan seven times, and thy flesh shall come again to thee, and thou shalt be clean. But Naaman was wroth, and went away, and said, Behold, I thought, he will surely come out to me, and stand, and call on the name of the Lord his God, and strike his hand over the place, and recover the leper. Are not Abana and Pharpar, rivers of Damascus, better than all the waters of Israel? may I not wash in them, and be clean? So he turned and went away in a rage. And his servants came near, and spake unto him, and said, My father, if the prophet had bid thee do some great thing, wouldest thou not have done it? how much rather then, when he saith to thee, Wash, and be clean? Then went he down, and dipped himself seven times in Jordan, according to the saying of the man of God: and his flesh came again like unto the flesh of a little child, and he was clean.

And he returned to the man of God, he and all his company, and came, and stood before him: and he said, Behold, now I know that there is no God in all the earth, but in Israel: now therefore, I pray 
thee, take a blessing of thy servant. But he said, As the Lord liveth, before whom I stand, I will receive none. And he urged him to take it; but he refused. And Naaman said, Shall there not then, I pray thee, be given to thy servant two mules' burden of earth? for thy servant will henceforth offer neither burnt offering nor sacrifice unto other gods, but unto the Lord. In this thing the Lord pardon thy servant, that when my master goeth into the house of Rimmon to worship there, and he leaneth on my hand, and I bow myself in the house of Rimmon: when I bow down myself in the house of Rimmon, the Lord pardon thy servant in this thing. And he said unto him, Go in peace. So he departed from him a little way.

But Gehazi, the servant of Elisha the man of God, said, Behold, my master hath spared Naaman this Syrian, in not receiving at his hands that which he brought: but, as the Lord liveth, I will run after him, and take somewhat of him. So Gehazi followed after Naaman. And when Naaman saw him running after him, he lighted down from the chariot to meet him, and said, Is all well? And he said, All is well. My master hath sent me, saying, Behold, even now there be come to me from mount Ephraim two young men of the sons of the prophets : give them, I pray thee, a talent of silver, and two changes of garments. And Naaman said, Be content, take two talents. And he urged him, and bound two talents of silver in two bags, with two changes of garments, and laid them upon two of his servants; and they bare them before him. And when he came to the tower, he took them 
from their hand, and bestowed them in the house: and he let the men go, and they departed. But he went in, and stood before his master. And Elisha said unto him, Whence comest thou, Gehazi? And he said, Thy servant went no whither. And he said unto him, Went not mine heart with thee, when the man turned again from his chariot to meet thee? Is it a time to receive money, and to receive garments, and oliveyards, and vineyards, and sheep, and oxen, and menservants, and maidservants? The leprosy therefore of Naaman shall cleave unto thee, and unto thy seed for ever. And he went out from his presence a leper as white as snow.

\section{LI.}

\section{$\mathcal{F e b u}$ and $\mathcal{F e z e b e l}$.}

II Kings ix.

And Elisha the prophet called one of the children of the prophets, and said unto him, Gird up thy loins, and take this box of oil in thine hand, and go to Ramoth-gilead: and when thou comest thither, look out there Jehu the son of Jehoshaphat the son of Nimshi, and go in, and make him arise up from among his brethren, and carry him to an inner chamber; then take the box of oil, and pour it on his head, and say, Thus saith the Lord, I have anointed thee king over Israel. Then open the door, and flee, and tarry not.

So the young man, even the young man the prophet, went to Ramoth-gilead. And when he 
came, behold, the captains of the host were sitting; and he said, I have an errand to thee, $O$ captain. And Jehu said, Unto which of all us? And he said, To thee, O captain. And he arose, and went into the house; and he poured the oil on his head, and said unto him, Thus saith the Lord God of Israel, I have anointed thee king over the people of the Lord, even over Israel. And thou shalt smite the house of Ahab thy master, that I may avenge the blood of my servants the prophets, and the blood of all the servants of the Lord, at the hand of Jezebel. For the whole house of Ahab shall perish: and I will cut off from Ahab him that pisseth against the wall, and him that is shut up and left in Israel: and I will make the house of Ahab like the house of Jeroboam the son of Nebat, and like the house of Baasha the son of Ahijah: and the dogs shall eat Jezebel in the portion of Jezreel, and there shall be none to bury her. And he opened the door and fled.

Then Jehu came forth to the servants of his lord: and one said unto him, Is all well? wherefore came this mad fellow to thee? And he said unto them, Ye know the man, and his communication. And they said, It is false; tell us now. And he said, Thus and thus spake he to me, saying, Thus saith the Lord, I have anointed thee king over Israel. Then they hasted, and took every man his garment, and put it under him on the top of the stairs, and blew with trumpets, saying, Jehu is king. So Jehu the son of Jehoshaphat the son of Nimshi conspired against Joram. (Now Joram had kept Ramothgilead, he and all Israel, because of Hazael king of 
Syria. But king Joram was returned to be healed in Jezreel of the wounds which the Syrians had given him, when he fought with Hazael king of Syria.) And Jehu said, If it be your minds, then let none go forth nor escape out of the city to go to tell it in Jezreel.

So Jehu rode in a chariot, and went to Jezreel; for Joram lay there. And Ahaziah king of Judah was come down to see Joram. And there stood a watchman on the tower in Jezreel, and he spied the company of Jehu as he came, and said, I see a company. And Joram said, Take an horseman, and send to meet them, and let him say, Is it peace? So there went one on horseback to meet him, and said, Thus saith the king, Is it peace? And Jehu said, What hast thou to do with peace? turn thee behind me. And the watchman told, saying, The messenger came to them, but he cometh not again. Then he sent out a second on horseback, which came to them, and said, Thus saith the king, Is it peace? And Jehu answered, What hast thou to do with peace? turn thee behind me. And the watchman told, saying, He came even unto them, and cometh not again: and the driving is like the driving of Jehu the son of Nimshi; for he driveth furiously. And Joram said, Make ready. And his chariot was made ready. And Joram king of Israel and Ahaziah king of Judah went out, each in his chariot, and they went out against Jehu, and met him in the portion of Naboth the Jezreelite.

And it came to pass, when Joram saw Jehu, that he said, Is it peace, Jehu? And he answered, What peace, so long as the whoredoms of thy mother 
Jezebel and her witchcrafts are so many? And Joram turned his hands, and fled, and said to Ahaziah, There is treachery, $\mathrm{O}$ Ahaziah. And Jehu drew a bow with his full strength, and smote Jehoram between his arms, and the arrow went out at his heart, and he sunk down in his chariot. Then said Jehu to Bidkar his captain, Take up, and cast him in the portion of the field of Naboth the Jezreelite: for remember how that, when I and thou rode together after Ahab his father, the Lord laid this burden upon him; surely I have seen yesterday the blood of Naboth, and the blood of his sons, saith the Lord; and I will requite thee in this plat, saith the Lord. Now therefore take and cast him into the plat of ground, according to the word of the Lord.

But when Ahaziah the king of Judah saw this, he fled by the way of the garden house. And Jehu followed after him, and said, Smite him also in the chariot. And they did so at the going up to Gur, which is by Ibleam. And he fled to Megiddo, and died there. And his servants carried him in a chariot to Jerusalem, and buried him in his sepulchre with his fathers in the city of David. And in the eleventh year of Joram the son of Ahab began Ahaziah to reign over Judah.

And when Jehu was come to Jezreel, Jezebel heard of it; and she painted her face, and tired her head, and looked out at a window. And as Jehu entered in at the gate, she said, Had Zimri peace, who slew his master? And he lifted up his face to the window, and said, Who is on my side? who? And there looked out to him two or three eunuchs. 
And he said, Throw her down. So they threw her down: and some of her blood was sprinkled on the wall, and on the horses: and he trode her under foot. And when he was come in, he did eat ai. drink, and said, Go see now this cursed wornan, and bury her: for she is a king's daughter. And they went to bury her: but they found no more of her than the skull, and the feet, and the palms of her hands. Wherefore they came again, and told him. And he said, This is the word of the Lord, which he spake by his servant Elijah the Tishbite, saying, In the portion of Jezreel shall dogs eat the flesh of Jezebel: and the carcase of Jezebel shall be as dung upon the face of the field in the portion of Jezreel; so that they shall not say, This is Jezebel.

\section{LII.}

\section{The Deatb of Elisba.}

II Kings xiii. 14-20.

Now Elisha was fallen sick of his sickness whereof he died. And Joash the king of Israel came down unto him, and wept over his face, and said, O my father, my father, the chariot of Israel, and the horsemen thereof. And Elisha said unto him, Take bow and arrows. And he took unto him bow and arrows. And he said to the king of Israel, Put thine hand upon the bow. And he put his hand upon it: and Elisha put his hands upon the king's hands. And he said, Open the window eastward. And he opened it. Then Elisha said, Shoot. 
And he shot. And he said, The arrow of the Lord's deliverance, and the arrow of deliverance from Syria: for thou shalt smite the Syrians in Aphek, till thou have consumed them. And he said, Take the arrows. And he took them. And he said unto the king of Israel, Smite upon the ground. And he smote thrice, and stayed. And the man of God was wroth with him, and said, Thou shouldest have smitten five or six times; then hadst thou smitten Syria till thou hadst consumed it: whereas now thou shalt smite Syria but thrice. And Elisha died, and they buried him.

\section{LIII.}

\section{Tbezekiab.}

II Kings xviii. I-I 7; xix. I-I9; xix. 35-xx.

Now it came to pass in the third year of Hoshea son of Elah king of Israel, that Hezekiah the son of Ahaz king of Judah began to reign. Twenty and five years old was he when he began to reign; and he reigned twenty and nine years in Jerusalem. His mother's name also was Abi, the daughter of Zachariah. And he did that which was right in the sight of the Lord, according to all that David his father did. He removed the high places, and brake the images, and cut down the groves, and brake in pieces the brasen serpent that Moses had made: for unto those days the children of Israel did burn incense to it: and he called it Nehushtan [i.e. "A piece of brass"]. He trusted in the Lord God of Israel; so that after him was none like him 
among all the kings of Judah, nor any that were before him. For he clave to the Lord, and departed not from following him, but kept his commandments, which the Lord commanded Moses. And the Lord was with him; and he prospered whithersoever he went forth: and he rebelled against the king of Assyria, and served him not. He smote the Philistines, even unto Gaza, and the borders thereof, from the tower of the watchmen to the fenced city.

And it came to pass in the fourth year of king Hezekiah, which was the seventh year of Hoshea son of Elah king of Israel, that Shalmaneser king of Assyria came up against Samaria, and besieged it. And at the end of three years they took it: even in the sixth year of Hezekiah, that is the ninth year of Hoshea king of Israel, Samaria was taken. And the king of Assyria did carry away Israel unto Assyria; and put them in Halah and in Habor by the river of Gozan, and in the cities of the Medes: because they obeyed not the voice of the Lord their God, but transgressed his covenant, and all that Moses the servant of the Lord commanded, and would not hear them, nor do them.

Now in the fourteenth year of king Hezekiah did Sennacherib king of Assyria come up against all the fenced cities of Judah, and took them. And Hezekiah king of Judah sent to the king of Assyria to Lachish, saying, I have offended; return from me: that which thou puttest on me will I bear. And the king of Assyria appointed unto Hezekiah king of Judah three hundred talents of silver and thirty talents of gold. And Hezekiah gave him all the silver that was found in the house of the Lord, 
and in the treasures of the king's house. At that time did Hezekiah cut off the gold from the doors of the temple of the Lord, and from the pillars which Hezekiah king of Judah had overlaid, and gave it to the king of Assyria.

And the king of Assyria sent Tartan and Rabsaris and Rab-shakeh from Lachish to king Hezekiah with a great host against Jerusalem. And they went up and came to Jerusalem.

And it came to pass, when king Hezekiah heard it [that Rab-shakeh had incited the people against him], that he rent his clothes, and covered himself with sackcloth, and went into the house of the Lord. And he sent Eliakim, which was over the household, and Shebna the scribe, and the elders of the priests, covered with sackcloth, to Isaiah the prophet the son of Amoz. And they said unto him, Thus saith Hezekiah, This day is a day of trouble, and of rebuke, and blasphemy: for the children are come to the birth, and there is not strength to bring forth. It may be the Lord thy God will hear all the words of Rab-shakeh, whom the king of Assyria his master hath sent to reproach the living God; and will reprove the words which the Lord thy God hath heard: wherefore lift up thy prayer for the remnant that are left. So the servants of king Hezekiah came to Isaiah. And Isaiah said unto them, Thus shall ye say to your master, Thus saith the Lord, Be not afraid of the words which thou hast heard, with which the servants of the king of Assyria have blasphemed me. Behold, I will send a blast upon him, and he shall hear a rumour, and shall return 
to his own land; and I will cause him to fall by the sword in his own land.

So Rab-shakeh returned, and found the king of Assyria warring against Libnah: for he had heard that he was departed from Lachish. And when he heard say of Tirhakah king of Ethiopia, Behold, he is come out to fight against thee : he sent messengers again unto Hezekiah, saying, Thus shall ye speak to Hezekiah king of Judah, saying, Let not thy God in whom thou trustest deceive thee, saying, Jerusalem shall not be delivered into the hand of the king of Assyria. Behold, thou hast heard what the kings of Assyria have done to all lands, by destroying them utterly: and shalt thou be delivered? Have the gods of the nations delivered them which my fathers have destroyed; as Gozan, and Haran, and Rezeph, and the children of Eden which were in Thelasar? Where is the king of Hamath, and the king of Arpad, and the king of the city of Sepharvaim, of Hena, and Ivah?

And Hezekiah received the letter of the hand of the messengers, and read it: and Hezekiah went up into the house of the Lord, and spread it before the Lord. And Hezekiah prayed before the Lord, and said, O Lord God of Israel, which dwellest between the cherubims, thou art the God, even thou alone, of all the kingdoms of the earth; thou hast made heaven and earth. Lord, bow down thine ear, and hear: open, Lord, thine eyes, and see: and hear the words of Sennacherib, which hath sent him to reproach the living God. Of a truth, Lord, the kings of Assyria have destroyed the nations and their lands, and have cast their gods into the fire: 
for they were no gods, but the work of men's hands, wood and stone: therefore they have destroyed them. Now therefore, O Lord our God, I beseech thee, save thou us out of his hand, that all the kingdoms of the earth may know that thou art the Lord God, even thou only.

And it came to pass that night, that the angel of the Lord went out, and smote in the camp of the Assyrians an hundred fourscore and five thousand: and when they arose early in the morning, behold, they were all dead corpses. So Sennacherib king of Assyria departed, and went and returned, and dwelt at Nineveh. And it came to pass, as he was worshipping in the house of Nisroch his god, that Adrammelech and Sharezer his sons smote him with the sword: and they escaped into the land of Armenia. And Esarhaddon his son reigned in his stead.

In those days was Hezekiah sick unto death. And the prophet Isaiah the son of Amoz came to him, and said unto him, Thus saith the Lord, Set thine house in order; for thou shalt die, and not live. Then he turned his face to the wall, and prayed unto the Lord, saying, I beseech thee, $\mathrm{O}$ Lord, remember now how I have walked before thee in truth and with a perfect heart, and have done that which is good in thy sight. And Hezekiah wept sore.

And it came to pass, afore Isaiah was gone out into the middle court, that the word of the Lord came to him, saying, Turn again, and tell Hezekiah the captain of my people, Thus saith the Lord, the 
God of David thy father, I have heard thy prayer, I have seen thy tears: behold, I will heal thee: on the third day thou shalt go up unto the house of the Lord. And I will add unto thy days fifteen years; and I will deliver thee and this city out of the hand of the king of Assyria; and I will defend this city for mine own sake, and for my servant David's sake. And Isaiah said, Take a lump of figs. And they took and laid it on the boil, and he recovered. And Hezekiah said unto Isaiah, What shall be the sign that the Lord will heal me, and that I shall go up into the house of the Lord the third day? And Isaiah said, This sign shalt thou have of the Lord, that the Lord will do the thing that he hath spoken: shall the shadow go forward ten degrees, or go back ten degrees? And Hezekiah answered, It is a light thing for the shadow to go down ten degrees: nay, but let the shadow return backward ten degrees. And Isaiah the prophet cried unto the Lord: and he brought the shadow ten degrees backward, by which it had gone down in the dial of Ahaz.

At that time Berodach-baladan, the son of Baladan, king of Babylon, sent letters and a present unto Hezekiah: for he had heard that Hezekiah had been sick. And Hezekiah hearkened unto them, and shewed them all the house of his precious things, the silver, and the gold, and the spices, and the precious ointment, and all the house of his armour, and all that was found in his treasures: there was nothing in his house, nor in all his dominion, that Hezekiah shewed them not.

Then came Isaiah the prophet unto king Heze- 
kiah, and said unto him, What said these men? and from whence came they unto thee? And Hezekiah said, They are come from a far country, even from Babylon. And he said, What have they seen in thine house? And Hezekiah answered, All the things that are in mine house have they seen: there is nothing among my treasures that I have not shewed them. And Isaiah said unto Hezekiah, Hear the word of the Lord. Behold, the days come, that all that is in thine house, and that which thy fathers have laid up in store unto this day, shall be carried unto Babylon: nothing shall be left, saith the Lord. And of thy sons that shall issue from thee, which thou shalt beget, shall they take away; and they shall be eunuchs in the palace of the king of Babylon. Then said Hezekiah unto Isaiah, Good is the word of the Lord which thou hast spoken. And he said, Is it not good, if peace and truth be in my days?

And the rest of the acts of Hezekiah, and all his might, and how he made a pool, and a conduit, and brought water into the city, are they not written in the book of chronicles of the kings of Judah? And Hezekiah slept with his fathers: and Manasseh his son reigned in his stead.

\section{LIV.}

\section{Fogtab's TRenewal of the Covenant.}

II Kings xxii.-xxiii. 5 .

JosinII was eight years old when he began to reign, and he reigned thirty and one years in Jeru- 
salem. And his mother's name was. Jedidah, the daughter of Adaiah of Boscath. And he did that which was right in the sight of the Lord, and walked in all the way of David his father, and turned not aside to the right hand or to the left.

And it came to pass in the eighteenth year of king Josiah, that the king sent Shaphan the son of Azaliah, the son of Meshullam, the scribe, to the house of the Lord, saying, Go up to Hilkiah the high priest, that he may sum the silver which is brought into the house of the Lord, which the keepers of the door have gathered of the people: and let them deliver it into the hand of the doers of the work, that have the oversight of the house of the Lord: and let them give it to the doers of the work which is in the house of the Lord, to repair the breaches of the house, unto carpenters, and builders, and masons, and to buy timber and hewn stone to repair the house. Howbeit there was no reckoning made with them of the money that was delivered into their hand, because they dealt faithfully.

And Hilkiah the high priest said unto Shaphan the scribe, I have found the book of the law in the house of the Lord. And Hilkiah gave the book to Shaphan, and he read it. And Shaphan the scribe came to the king, and brought the king word again, and said, Thy servants have gathered the money that was found in the house, and have delivered it into the hand of them that do the work, that have the oversight of the house of the Lord. And Shaphan the scribe shewed the king, saying, Hilkiah the priest hath delivered me a book. And Shaphan 
read it before the king. And it came to pass, when the king had heard the words of the book of the law, that he rent his clothes. And the king commanded Hilkiah the priest, and Ahikam the son of Shaphan, and Achbor the son of Michaiah, and Shaphan the scribe, and Asahiah a servant of the king's, saying, Go ye, enquire of the Lord for me, and for the people, and for all Judah, concerning the words of this book that is found: for great is the wrath of the Lord that is kindled against us, because our fathers have not hearkened unto the words of this book, to do according unto all that which is written concerning us.

So Hilkiah the priest, and Ahikam, and Achbor, and Shaphan, and Asahiah, went unto Huldah the prophetess, the wife of Shallum the son of Tikvah, the son of Harhas, keeper of the wardrobe; (now she dwelt in Jerusalem in the college;) and they communed with her. And she said unto them, Thus saith the Lord God of Israel, Tell the man that sent you to me, Thus saith the Lord, Behold, I will bring evil upon this place, and upon the inhabitants thereof, even all the words of the book which the king of Judah hath read: because they have forsaken me, and have burned incense unto other gods, that they might provoke me to anger with all the works of their hands; therefore my wrath shall be kindled against this place, and shall not be quenched. But to the king of Judah which sent you to enquire of the Lord, thus shall ye say to him, Thus saith the Lord God of Israel, As touching the words which thou hast heard; bccause thine heart was tender, and thou hast humbled thyself before 
the Lord, when thou heardest what I spake against this place, and against the inhabitants thereof, that they should become a desolation and a curse, and hast rent thy clothes, and wept before me; I also have heard thee, saith the Lord. Behold therefore, I will gather thee unto thy fathers, and thou shalt be gathered into thy grave in peace; and thine eyes shall not see all the evil which I will bring upon this place. And they brought the king word again.

And the king sent, and they gathered unto him all the elders of Judah and of Jerusalem. And the king went up into the house of the Lord and all the men of Judah and all the inhabitants of Jerusalem with him, and the priests, and the prophets, and all the people, both small and great: and he read in their ears all the words of the book of the covenant which was found in the house of the Lord. And the king stood by a pillar, and made a covenant before the Lord, to walk after the Lord, and to keep his commandments and his testimonies and his statutes with all their heart and all their soul, to perform the words of this covenant that were written in this book. And all the people stood to the covenant. And the king commanded Hilkiah the high priest, and the priests of the second order, and the keepers of the door, to bring forth out of the temple of the Lord all the vessels that were made for Baal, and for the grove, and for all the host of heaven: and he burned them without Jerusalem in the fields of Kidron, and carried the ashes of them unto Beth-el. And he put down the idolatrous priests, whom the kings of Judah had ordained to burn incense in the high places in the cities of 
Judah, and in the places round about Jerusalem; them also that burned incense unto Baal, to the sun, and to the moon, and to the planets, and to all the host of heaven.

\section{LV.}

\section{The Capture of Ferusalem.}

II Kings xxiv. 8-xxv. I3.

JEHoraCHIN was eighteen years old when he began to reign, and he reigned in Jerusalem three months. And his mother's name was Nehushta, the daughter of Elnathan of Jerusalem. And he did that which was evil in the sight of the Lord, according to all that his father had done. At that time the servants of Nebuchadnezzar king of Babylon came up against Jerusalem, and the city was besieged. And Nebuchadnezzar king of Babylon came against the city, and his servants did besiege it. And Jehoiachin the king of Judah went out to the king of Babylon, he, and his mother, and his servants, and his princes, and his officers: and the king of Babylon took him in the eighth year of his reign. And he carried out thence all the treasures of the house of the Lord, and the treasures of the king's house, and cut in pieces all the vessels of gold which Solomon king of Israel had made in the temple of the Lord, as the Lord had said. And he carried away all Jerusalem, and all the princes, and all the mighty men of valour, even ten thousand captives, and all the craftsmen and smiths: none remained, save the poorest sort of the people of the land. 
And he carried away Jehoiachin to Babylon, and the king's mother, and the king's wives, and his officers, and the mighty of the land, those carried he into captivity from Jerusalem to Babylon. And all the men of might, even seven thousand, and craftsmen and smiths a thousand, all that were strong and apt for war, even them the king of Babylon brought captive to Babylon.

And the king of Babylon made Mattaniah his father's brother king in his stead, and changed his name to Zedekiah. Zedekiah was twenty and one years old when he began to reign, and he reigned eleven years in Jerusalem. And his mother's name was Hamutal, the daughter of Jeremiah of Libnah. And he did that which was evil in the sight of the Lord, according to all that Jehoiakim had done. For through the anger of the Lord it came to pass in Jerusalem and Judah, until he had cast them out from his presence, that Zedekiah rebelled against the king of Babylon.

And it came to pass in the ninth year of his reign, in the tenth month, in the tenth day of the month, that Nebuchadnezzar king of Babylon came, he, and all his host, against Jerusalem, and pitched against it ; and they built forts against it round about. And the city was besieged unto the eleventh year of king Zedekiah. And on the ninth day of the fourth month the famine prevailed in the city, and there was no bread for the people of the land. And the city was broken up, and all the men of war fled by night by the way of the gate between two walls, which is by the king's garden: (now the Chaldees were against the city round about:) and the king 
went the way toward the plain. And the army of the Chaldees pursued after the king, and overtook him in the plains of Jericho: and all his army were scattered from him. So they took the king, and brought him up to the king of Babylon to Riblah; and they gave judgment upon him. And they slew the sons of Zedekiah before his eyes, and put out the eyes of Zedekiah, and bound him with fetters of brass, and carried him to Babylon.

And in the fifth month, on the seventh day of the month, which is the nineteenth year of king Nebuchadnezzar king of Babylon, came Nebuzaradan, captain of the guard, a servant of the king of Babylon, unto Jerusalem: and he burnt the house of the Lord, and the king's house, and all the houses of Jerusalem, and every great man's house burnt he with fire. And all the army of the Chaldees, that were with the captain of the guard, brake down the walls of Jerusalem round about. Now the rest of the people that were left in the city, and the fugitives that fell away to the king of Babylon, with the remnant of the multitude, did Nebuzaradan the captain of the guard carry away. But the captain of the guard left of the poor of the land to be vinedressers and husbandmen. And the pillars of brass that were in the house of the Lord, and the bases, and the brasen sea that was in the house of the Lord, did the Chaldees break in pieces, and carried the brass of them to Babylon. 


\section{LVI.}

\section{Estber.}

Esther.

Now it came to pass in the days of Ahasuerus, (this is Ahasuerus which reigned, from India even unto Ethiopia, over an hundred and seven and twenty provinces:) that in those days, when the king Ahasuerus sat on the throne of his kingdom, which was in Shushan the palace, in the third year of his reign, he made a feast unto all his princes and his servants; the power of Persia and Media, the nobles and princes of the provinces, being before him: when he shewed the riches of his glorious kingdom and the honour of his excellent majesty many days, even an hundred and fourscore days. And when these days were expired, the king made a feast unto all the people that were present in Shushan the palace, both unto great and small, seven days, in the court of the garden of the king's palace; where were white, green, and blue, hangings, fastened with cords of fine linen and purple to silver rings and pillars of marble: the beds were of gold and silver, upon a pavement of red, and blue, and white, and black, marble. And they gave them drink in vessels of gold, (the vessels being diverse one from another,) and royal wine in abundance, according to the state of the king. And the drinking was according to the law; none did compel: for so the king had appointed to all the officers of his house, that they should do according to every man's 
pleasure. Also Vashti the queen made a feast for the women in the royal house which belonged to king Ahasuerus.

On the seventh day, when the heart of the king was merry with wine, he commanded Mehuman, Biztha, Harbona, Bigtha, and Abagtha, Zethar, and Carcas, the seven chamberlains that served in the presence of Ahasuerus the king, to bring Vashti the queen before the king with the crown royal, to shew the people and the princes her beauty: for she was fair to look on. But the queen Vashti refused to come at the king's commandment by his chamberlains: therefore was the king very wroth, and his anger burned in him.

Then the king said to the wise men, which knew the times, (for so was the king's manner toward all that knew law and judgment: and the next unto him was Carshena, Shethar, Admatha, Tarshish, Meres, Marsena, and Memucan, the seven princes of Persia and Media, which saw the king's face, and which sat the first in the kingdom;) What shall we do unto the queen Vashti according to law, because she hath not performed the commandment of the king Ahasuerus by the chamberlains? And Memucan answered before the king and the princes, Vashti the queen hath not done wrong to the king only, but also to all the princes, and to all the people that are in all the provinces of the king Ahasuerus. For this deed of the queen shall come abroad unto all women, so that they shall despise their husbands in their eyes, when it shall be reported. The king Ahasuerus commanded Vashti the queen to be brought in before him, but she came 
not. Likewise shall the ladies of Persia and Media say this day unto all the king's princes, which have heard of the deed of the queen. Thus shall there arise too much contempt and wrath. If it please the king, let there go a royal commandment from him, and let it be written among the laws of the Persians and the Medes, that it be not altered, That Vashti come no more before king Ahasuerus; and let the king give her royal estate unto another that is better than she. And when the king's decree which he shall make shall be published throughout all his empire, (for it is great,) all the wives shall give to their husbands honour, both to great and small.

And the saying pleased the king and the princes; and the king did according to the word of Memucan: for he sent letters into all the king's provinces, into every province according to the writing thereof, and to every people after their language, that every man should bear rule in his own house, and that it should be published according to the language of every people.

After these things, when the wrath of king Ahasuerus was appeased, he remembered Vashti, and what she had done, and what was decreed against her. Then said the king's servants that ministered unto him, Let there be fair young virgins sought for the king: and let the king appoint officers in all the provinces of his kingdom, that they may gather together all the fair young virgins unto Shushan the palace, to the house of the women, unto the custody of Hege the king's chamberlain, keeper of the women; and let their things for purifi- 
cation be given them: and let the maiden which pleaseth the king be queen instead of Vashti. And the thing pleased the king; and he did so.

Now in Shushan the palace there was a certain Jew, whose name was Mordecai, the son of Jair, the son of Shimei, the son of Kish, a Benjamite; who had been carried away from Jerusalem with the captivity which had been carried away with Jeconiah king of Judah, whom Nebuchadnezzar the king of Babylon had carried away. And he brought up Hadassah, that is, Esther, his uncle's daughter: for she had neither father nor mother, and the maid was fair and beautiful; whom Mordecai, when her father and mother were dead, took for his own daughter.

So it came to pass, when the king's commandment and his decree was heard, and when many maidens were gathered together unto Shushan the palace, to the custody of Hegai, that Esther was brought also unto the king's house, to the custody of Hegai, keeper of the women. And the maiden pleased him, and she obtained kindness of him ; and he speedily gave her her things for purification, with such things as belonged to her, and seven maidens, which were meet to be given her, out of the king's house: and he preferred her and her maids unto the best place of the house of the women. Esther had not shewed her people nor her kindred: for Mordecai had charged her that she should not shew it. And Mordecai walked every day before the court of the women's house, to know how Esther did, and what should become of her. 
Now when every maid's turn was come to go in to king Ahasuerus, after that she had been twelver months, according to the manner of the women, (for so were the days of their purifications accomplished, to wit, six months with oil of myrrh, and six months with sweet odours, and with other things for the purifying of the women;) then thus came every maiden unto the king; whatsoever she desired was given her to go with her out of the house of the women unto the king's house. In the evening she went, and on the morrow she returned into the second house of the women, to the custody of Shaashgaz, the king's chamberlain, which kept the concubines: she came in unto the king no more, except the king delighted in her, and that she were called by name.

Now when the turn of Esther, the daughter of Abihail the uncle of Mordecai, who had taken her for his daughter, was come to go in unto the king, she required nothing but what Hegai the king's chamberlain, the keeper of the women, appointed. And Esther obtained favour in the sight of all them that looked upon her. So Esther was taken unto king Ahasuerus into his house royal in the tenth month, which is the month Tebeth, in the seventh year of his reign. And the king loved Esther above all the women, and she obtained grace and favour in his sight more than all the virgins; so that he set the royal crown upon her head, and made her queen instead of Vashti. Then the king made a great feast unto all his princes and his servants, even Esther's feast; and he made a release to the provinces, and gave gifts, according to the state of 
the king. And when the virgins were gathered together the second time, then Mordecai sat in the king's gate. Esther had not yet shewed her kindred nor her people; as Mordecai had charged her: for Esther did the commandment of Mordecai, like as when she was brought up with him.

In those days, while Mordecai sat in the king's gate, two of the king's chamberlains, Bigthan and Teresh, of those which kept the door, were wroth, and sought to lay hand on the king Ahasuerus. And the thing was known to Mordecai, who told it unto Esther the queen; and Esther certified the king thereof in Mordecai's name. And when inquisition was made of the matter, it was found out; therefore they were both hanged on a tree: and it was written in the book of the chronicles before the king.

After these things did king Ahasuerus promote Haman the son of Hammedatha the Agagite, and advanced him, and set his seat above all the princes that were with him. And all the king's servants, that were in the king's gate, bowed, and reverenced Haman: for the king had so commanded concerning him. But Mordecai bowed not, nor did him reverence. Then the king's servants, which were in the king's gate, said unto Mordecai, Why transgressest thou the king's commandment? Now it came to pass, when they spake daily unto him, and he hearkened not unto them, that they told Haman, to see whether Mordecai's matters would stand: for he had told them that he was a Jew. And when Haman saw that Mordecai bowed not, nor did him reverence, then was Haman full of wrath. And he 
thought scorn to lay hands on Mordecai alone; for they had shewed him the people of Mordecai: wherefore Haman sought to destroy all the Jews that were throughout the whole kingdom of Ahasuerus, even the people of Mordecai.

In the first month, that is, the month Nisan, in the twelfth year of king Ahasuerus, they cast Pur, that is, the lot, before Haman from day to day, and from month to month, to the twelfth month, that is, the month Adar. And Haman said unto king Ahasuerus, There is a certain people scattered abroad and dispersed among the people in all the provinces of thy kingdom; and their laws are diverse from all people; neither keep they the king's laws: therefore it is not for the king's profit to suffer them. If it please the king, let it be written that they may be destroyed: and I will pay ten thousand talents of silver to the hands of those that have the charge of the business, to bring it into the king's treasuries. And the king took his ring from his hand, and gave it unto Haman the son of Hammedatha the Agagite, the Jews' enemy. And the king said unto Haman, The silver is given to thee, the people also, to do with them as it seemeth good to thee.

Then were the king's scribes called on the thirteenth day of the first month, and there was written according to all that Haman had commanded unto the king's lieutenants, and to the governors that were over every province, and to the rulers of every people of every province according to the writing thereof, and to every people after their language; in the name of king Ahasuerus was it written, and 
sealed with the king's ring. And the letters were sent by posts into all the king's provinces, to destroy, to kill, and to cause to perish, all Jews, both young and old, little children and women, in one day, even upon the thirteenth day of the twelfth month, which is the month Adar, and to take the spoil of them for a prey. The copy of the writing for a commandment to be given in every province was published unto all people, that they should be ready against that day. The posts went out, being hastened by the king's commandment, and the decree was given in Shushan the palace. And the king and Haman sat down to drink; but the city Shushan was perplexed.

When Mordecai perceived all that was done, Mordecai rent his clothes, and put on sackcloth with ashes, and went out into the midst of the city, and cried with a loud and a bitter cry; and came even before the king's gate: for none might enter into the king's gate clothed with sackcloth. And in every province, whithersoever the king's commandment and his decree came, there was great mourning among the Jews, and fasting, and weeping, and wailing; and many lay in sackcloth and ashes.

So Esther's maids and her chamberlains came and told it her. Then was the queen exceedingly grieved; and she sent raiment to clothe Mordecai, and to take away his sackcloth from him: but he received it not. Then called Esther for Hatach, one of the king's chamberlains, whom he had appointed to attend upon her, and gave him a commandment to Mordecai, to know what it was, and why it was. So Hatach went forth to Mordecai 
unto the street of the city, which was before the king's gate. And Mordecai told him of all that had happened unto him, and of the sum of the money that Haman had promised to pay to the king's treasuries for the Jews, to destroy them. Also he gave him the copy of the writing of the decree that was given at Shushan to destroy them, to shew it unto Esther, and to declare it unto her, and to charge her that she should go in unto the king to make supplication unto him, and to make request before him for her people. And Hatach came and told Esther the words of Mordecai. Again Esther spake unto Hatach, and gave him commandment unto Mordecai; All the king's servants, and the people of the king's provinces, do know, that whosoever, whether man or woman, shall come unto the king into the inner court, who is not called, there is one law of his to put him to death, except such to whom the king shall hold out the golden sceptre, that he may live: but I have not been called to come in unto the king these thirty days. And they told to Mordecai Esther's words.

Then Mordecai commanded to answer Esther, Think not with thyself that thou shalt escape in the king's house, more than all the Jews. For if thou altogether holdest thy peace at this time, then shall there enlargement and deliverance arise to the Jews from another place; but thou and thy father's house shall be destroyed: and who knoweth whether thou art come to the kingdom for such a time as this? Then Esther bade them return Mordecai this answer, Go, gather together all the Jews that are present in Shushan, and fast ye for me, and neither 
eat nor drink three days, night or day: I also and my maidens will fast likewise; and so will I go in unto the king, which is not according to the law: and if I perish, I perish. So Mordecai went his way, and did according to all that Esther had commanded him.

Now it came to pass on the third day, that Esther put on her royal apparel, and stood in the inner court of the king's house, over against the king's house: and the king sat upon his royal throne in the royal house, over against the gate of the house. And it was so, when the king saw Esther the queen standing in the court, that she obtained favour in his sight: and the king held out to Esther the golden sceptre that was in his hand. So Esther drew near, and touched the top of the sceptre. Then said the king unto her, What wilt thou, queen Esther? and what is thy request? it shall be even given thee to the half of the kingdom. And Esther answered, If it seem good unto the king, let the king and Haman come this day unto the banquet that I have prepared for him. Then the king said, Cause Haman to make haste, that he may do as Esther hath said. So the king and Haman came to the banquet that Esther had prepared.

And the king said unto Esther at the banquet of wine, What is thy petition? and it shall be granted thee: and what is thy request? even to the half of the kingdom it shall be performed. Then answered Esther, and said, My petition and my request is; if I have found favour in the sight of the king, and if it please the king to grant my petition, and to perform my request, let the king and Haman come 
to the banquet that I shall prepare for them, and I will do to morrow as the king hath said.

Then went Haman forth that day joyful and with a glad heart: but when Haman saw Mordecai in the king's gate, that he stood not up, nor moved for him, he was full of indignation against Mordecai. Nevertheless Haman refrained himself: and when he came home, he sent and called for his friends, and Zeresh his wife. And Haman told them of the glory of his riches, and the multitude of his children, and all the things wherein the king had promoted him, and how he had advanced him above the princes and servants of the king. Haman said moreover, Yea, Esther the queen did let no man come in with the king unto the banquet that she had prepared but myself; and to morrow am I invited unto her also with the king. Yet all this availeth me nothing, so long as I see Mordecai the Jew sitting at the king's gate. Then said Zeresh his wife and all his friends unto him, Let a gallows be made of fifty cubits high, and to morrow speak thou unto the king that Mordecai may be hanged thereon: then go thou in merrily with the king unto the banquet. And the thing pleased Haman; and he caused the gallows to be made.

On that night could not the king sleep, and he commanded to bring the book of records of the chronicles; and they were read before the king. And it was found written, that Mordecai had told of Bigthana and Teresh, two of the king's chamberlains, the keepers of the door, who sought to lay hand on the king Ahasuerus. And the king said, What honour and dignity hath been done to Mor- 
decai for this? Then said the king's servants that ministered unto him, There is nothing done for him. And the king said, Who is in the court? Now Haman was come into the outward court of the king's house, to speak unto the king to hang Mordecai on the gallows that he had prepared for him. And the king's servants said unto him, Behold, Haman standeth in the court. And the king said, Let him come in. So Haman came in. And the king said unto him, What shall be done unto the man whom the king delighteth to honour? Now Haman thought in his heart, To whom would the king delight to do honour more than to myself? And Haman answered the king, For the man whom the king delighteth to honour, let the royal apparel be brought which the king useth to wear, and the horse that the king rideth upon, and the crown royal which is set upon his head: and let this apparel and horse be delivered to the hand of one of the king's most noble princes, that they may array the man withal whom the king delighteth to honour, and bring him on horseback through the street of the city, and proclaim before him, Thus shall it be done to the man whom the king delighteth to honour. Then the king said to Haman, Make haste, and take the apparel and the horse, as thou hast said, and do even so to Mordecai the Jew, that sitteth at the king's gate: let nothing fail of all that thou hast spoken. Then took Haman the apparel and the horse, and arrayed Mordecai, and brought him on horseback through the street of the city, and proclaimed before him, Thus shall it be done unto the man whom the king delighteth to honour. 
And Mordecai came again to the king's gate. But Haman hasted to his house mourning, and having his head covered. And Haman told Zeresh his wife and all his friends every thing that had befallen him. Then said his wise men and Zeresh his wife unto him, If Mordecai be of the seed of the Jews, before whom thou hast begun to fall, thou shalt not prevail against him, but shalt surely fall before him. And while they were yet talking with him, came the king's chamberlains, and hasted to bring Haman unto the banquet that Esther had prepared.

So the king and Haman came to banquet with Esther the queen. And the king said again unto Esther on the second day at the banquet of wine, What is thy petition, queen Esther? and it shall be granted thee: and what is thy request? and it shall be performed, even to the half of the kingdom. Then Esther the queen answered and said, If I have found favour in thy sight, $\mathrm{O}$ king, and if it please the king, let my life be given me at my petition, and my people at my request: for we are sold, I and my people, to be destroyed, to be slain, and to perish. But if we had been sold for bondmen and bondwomen, I had held my tongue, although the enemy could not countervail the king's damage. Then the king Ahasuerus answered and said unto Esther the queen, Who is he, and where is he, that durst presume in his heart to do so? And Esther said, The adversary and enemy is this wicked Haman. Then Haman was afraid before the king and the queen.

And the king arising from the banquet of wine in his wrath went into the palace garden: and 
Haman stood up to make request for his life to Esther the queen; for he saw that there was evil determined against him by the king. Then the king returned out of the palace garden into the place of the banquet of wine ; and Haman was fallen upon the bed whereon Esther was. Then said the king, Will he force the queen also before me in the house? As the word went out of the king's mouth, they covered Haman's face. And Harbonah, one of the chamberlains, said before the king, Behold also the gallows fifty cubits high, which Haman had made for Mordecai, who had spoken good for the king, standeth in the house of Haman. Then the king said, Hang him thereon. So they hanged Haman on the gallows that he had prepared for Mordecai. Then was the king's wrath pacified.

On that day did the king Ahasterus give the house of Haman the Jews' enemy unto Esther the queen. And Mordecai came before the king; for Esther had told what he was unto her. And the king took off his ring, which he had taken from Haman, and gave it unto Mordecai. And Esther set Mordecai over the house of Haman.

And Esther spake yet again before the king, and fell down at his feet, and besought him with tears to put away the mischief of Haman the Agagite, and his device that he had devised against the Jews. Then the king held out the golden sceptre toward Esther. So Esther arose, and stood before the king, and said, If it please the king, and if I have found favour in his sight, and the thing seem right before the king, and I be pleasing in his eyes, let it be written to reverse the letters devised by 
Haman the son of Hammedatha the Agagite, which he wrote to destroy the Jews which are in all the king's provinces: for how can I endure to see the evil that shall come unto my people? or how can I endure to see the destruction of my kindred? Then the king Ahasuerus said unto Esther the queen and to Mordecai the Jew, Behold, I have given Esther the house of Haman, and him they have hanged upon the gallows, because he laid his hand upon the Jews. Write ye also for the Jews, as it liketh you, in the king's name, and seal it with the king's ring: for the writing which is written in the king's name, and sealed with the king's ring, may no man reverse.

Then were the king's scribes called at that time in the third month, that is, the month Sivan, on the three and twentieth lay thereof; and it was written according to all that Mordecai commanded unto the Jews, and to the lieutenants, and the deputies and rulers of the provinces which are from India unto Ethiopia, an hundred twenty and seven provinces, unto every province according to the writing thereof, and unto every people after their language, and to the Jews according to their writing, and according to their language. And he wrote in the king Ahasuerus' name, and sealed it with the king's ring, and sent letters by posts on horseback, and riders on mules, camels, and young dromedaries: wherein the king granted the Jews which were in every city to gather themselves together, and to stand for their life, to destroy, to slay, and to cause to perish, all the power of the people and province that would assault them, both little ones and women, 
and to take the spoil of them for a prey. Upon one day in all the provinces of king Ahasuerus, namely, upon the thirteenth day of the twelfth month, which is the month Adar. The copy of the writing for a commandment to be given in every province was published unto all people, and that the Jews should be ready against that day to avenge themselves on their enemies. So the posts that rode upon mules and camels went out, being hastened and pressed on by the king's commandment. And the decree was given at Shushan the palace.

And Mordecai went out from the presence of the king in royal apparel of blue and white, and with a great crown of gold, and with a garment of fine linen and purple: and the city of Shushan rejoiced and was glad. And the Jews had light, and gladness, and joy, and honour. And in every province, and in every city, whithersoever the king's commandment and his decree came, the Jews had joy and gladness, a feast and a good day. And many of the people of the land became Jews; for the fear of the Jews fell upon them.

Now in the twelfth month, that is, the month Adar, on the thirteenth day of the same, when the king's commandment and his decree drew near to be put in execution, in the day that the enemies of the Jews hoped to have power over them, (though it was turned to the contrary, that the Jews had rule over them that hated them;) the Jews gathered themselves together in their cities throughout all the provinces of the king Ahasuerus, to lay hand on such as sought their hurt: and no man could withstand them; for the fear of them 
fell upon all people. And all the rulers of the provinces, and the lieutenants, and the deputies, and officers of the king, helped the Jews; because the fear of Mordecai fell upon them. For Mordecai was great in the king's house, and his fame went out throughout all the provinces: for this man Mordecai waxed greater and greater.

Thus the Jews smote all their enemies with the stroke of the sword, and slaughter, and destruction, and did what they would unto those that hated them. And in Shushan the palace the Jews slew and destroyed five hundred men. And Parshandatha, and Dalphon, and Aspatha, and Poratha, and Adalia, and Aridatha, and Parmashta, and Arisai, and Aridai, and Vajezatha, the ten sons of Haman the son of Hammedatha, the enemy of the Jews, slew they; but on the spoil laid they not their hand. On that day the number of those that were slain in Shushan the palace was brought before the king.

And the king said unto Esther the queen, The Jews have slain and destroyed five hundred men in Shushan the palace, and the ten sons of Haman; what have they done in the rest of the king's provinces? now what is thy petition? and it shall be granted thee; or what is thy request further? and it shall be done. Then said Esther, If it please the king, let it be granted to the Jews which are in Shushan to do to morrow also according unto this day's decree, and let Haman's ten sons be hanged upon the gallows. And the king commanded it so to be done: and the decree was given at Shushan; and they hanged Haman's ten sons. For the Jews that were in Shushan gathered themselves together on the 
fourteenth day also of the month Adar, and slew three hundred men at Shushan; but on the prey they laid not their hand. But the other Jews that were in the king's provinces gathered themselves together, and stood for their lives, and had rest from their enemies, and slew of their foes seventy and five thousand, but they laid not their hands on the prey, on the thirteenth day of the month Adar; and on the fourteenth day of the same rested they, and made it a day of feasting and gladness. But the Jews that were at Shushan assembled together on the thirteenth day thereof, and on the fourteenth thereof; and on the fifteenth day of the same they rested, and made it a day of feasting and gladness. Therefore the Jews of the villages, that dwelt in the unwalled towns, made the fourteenth day of the month Adar a day of gladness and feasting, and a good day, and of sending portions one to another.

And Mordecai wrote these things, and sent letters unto all the Jews that were in all the provinces of the king Ahasuerus, both nigh and far, to stablish this among them, that they should keep the fourteentl day of the month Adar, and the fifteenth day of the same, yearly, as the days wherein the Jews rested from their enemies, and the month which was turned unto them from sorrow to joy, and from mourning into a good day: that they should make them days of feasting and joy, and of sending portions one to another, and gifts to the poor. And the Jews undertook to do as they had begun, and as Mordecai had written unto them; because Haman the son of Hammedatha, the Agagite, the enemy of all the Jews, had devised against the Jews 
to destroy them, and had cast Pur, that is, the lot, to consume them, and to destroy then; but when Esther came before the king, he commanded by letters that his wicked device, which he devised against the Jews, should return upon his own head, and that he and his sons should be hanged on the gallows. Wherefore they called these days Purim after the name of Pur. Therefore for all the words of this letter, and of that which they had seen concerning this matter, and which had come unto them, the Jews ordained, and took upon them, and upon their seed, and upon all such as joined themselves unto them, so as it should not fail, that they would keep these two days according to their writing, and according to their appointed time every year; and that these days should be remembered and kept throughout every generation, every family, every province, and every city; and that these days of Purim should not fail from among the Jews, nor the memorial of them perish from their seed.

Then Esther the queen, the daughter of Abihail, and Mordecai the Jew, wrote with all authority, to confirm this second letter of Purim. And he sent the letters unto all the Jews, to the hundred twenty and seven provinces of the kingdom of Ahasuerus, with words of peace and truth, to confirm these days of Purim in their times appointed, according as Mordecai the Jew and Esther the queen had enjoined them, and as they had decreed for themselves and for their seed, the matters of the fastings and their cry. And the decree of Esther confirmed these matters of Purim; and it was written in the book. 
And the king Ahasuerus laid a tribute upon the land, and upon the isles of the sea. And all the acts of his power and of his might, and the declaration of the greatness of Mordecai, whereunto the king advanced him, are they not written in the book of the chronicles of the kings of Media and Persia? For Mordecai the Jew was next unto king Ahasuerus, and great among the Jews, and accepted of the multitude of his brethren, seeking the wealth of his people, and speaking peace to all his seed.

\section{LVII.}

\section{Thebucbadilezjar's Dreams.}

Daniel ii. and iv.

AND in the second year of the reign of Nebuchadnezzar Nebuchadnezzar dreamed dreams, wherewith his spirit was troubled, and his sleep brake from him. Then the king commanded to call the magicians, and the astrologers, and the sorcerers, and the Chaldeans, for to shew the king his dreams. So they came and stood before the king. And the king said unto them, I have dreamed a dream, and my spirit was troubled to know the dream. Then spake the Chaldeans to the king in Syriack, O king, live for ever: tell thy servants the dream, and we will shew the interpretation. The king answered and said to the Chaldeans, The thing is gone from me: if ye will not make known unto me the dream, with the interpretation thereof, ye shall be cut in pieces, and your houses shall be made a dunghill. 
But if ye shew the dream, and the interpretation thereof, ye shall receive of me gifts and rewards and great honour: therefore shew me the dream, and the interpretation thereof. They answered again and said, Let the king tell his servants the dream, and we will shew the interpretation of it. The king answered and said, I know of certainty that ye would gain the time, because ye see the thing is gone from me. But if ye will not make known unto me the dream, there is but one decree for you: for ye have prepared lying and corrupt words to speak before me, till the time be changed: therefore tell me the dream, and I shall know that ye can shew me the interpretation thereof.

The Chaldeans answered before the king, and said, There is not a man upon the earth that can shew the king's matter: therefore there is no king, lord, nor ruler, that asked such things at any magician, or astrologer, or Chaldean. And it is a rare thing that the king requireth, and there is none other that can shew it before the king, except the gods, whose dwelling is not with flesh. For this cause the king was angry and very furious, and commanded to destroy all the wise men of Babylon. And the decree went forth that the wise men should be slain; and they sought Daniel and his fellows to be slain.

Then Daniel answered with counsel and wisdom to Arioch the captain of the king's guard, which was gone forth to slay the wise men of Babylon; he answered and said to Arioch the king's captain, Why is the decree so hasty from the king? Then Arioch made the thing known to Daniel. Then 
Daniel went in, and desired of the king that he would give him time, and that he would shew the king the interpretation. Then Daniel went to his house, and made the thing known to Hananiah, Mishael, and Azariah, his companions: that they would desire mercies of the God of heaven concerning this secret; that Daniel and his fellows should not perish with the rest of the wise men of Babylon.

Then was the secret revealed unto Daniel in a night vision. Then Daniel blessed the God of heaven. Daniel answered and said, Blessed be the name of God for ever and ever: for wisdom and might are his: and he changeth the times and the seasons: he removeth kings, and setteth up kings: he giveth wisdom unto the wise, and knowledge to them that know understanding: he revealeth the deep and secret things: he knoweth what is in the darkness, and the light dwelleth with him. I thank thee, and praise thee, $O$ thou God of my fathers, who hast given me wisdom and might, and hast made known unto me now what we desired of thee: for thou hast now made known unto us the king's matter.

Therefore Daniel went in unto Arioch, whom the king had ordained to destroy the wise men of Babylon: he went and said thus unto him; Destroy not the wise men of Babylon: bring me in before the king, and I will shew unto the king the interpretation. Then Arioch brought in Daniel before the king in haste, and said thus unto him, I have found a man of the captives of Judah, that will make known unto the king the interpretation. The king 
answered and said to Daniel, whose name was Belteshazzar, Art thou able to make known unto me the dream which I have seen, and the interpretation thereof?

Daniel answered in the presence of the king, and said, The secret which the king hath demanded cannot the wise men, the astrologers, the magicians, the soothsayers, shew unto the king; but there is a God in heaven that revealeth secrets, and maketh known to the king Nebuchadnezzar what shall be in the latter days. Thy dream, and the visions of thy head upon thy bed, are these; as for thee, $\mathrm{O}$ king, thy thoughts came into thy mind upon thy bed, what should come to pass hereafter: and he that revealeth secrets maketh known to thee what shall come to pass. But as for me, this secret is not revealed to me for any wisdom that I have more than any living, but for their sakes that shall make known the interpretation to the king, and that thou mightest know the thoughts of thy heart. Thou, $\mathrm{O}$ king, sawest, and behold a great image. This great image, whose brightness was excellent, stood before thee; and the form thereof was terrible. This image's head was of fine gold, his breast and his arms of silver, his belly and his thighs of brass, his legs of iron, his feet part of iron and part of clay. Thou sawest till that a stone was cut without hands, which smote the image upon his feet that were of iron and clay, and brake them to pieces. Then was the iron, the clay, the brass, the silver, and the gold, broken to pieces together, and became like the chaff of the summer threshingfloors; and the wind carried them away, that no place was 
found for them: and the stone that smote the image became a great mountain, and filled the whole earth.

This is the dream; and we will tell the interpretation thereof before the king. Thou, $\mathrm{O}$ king, art a king of kings: for the God of heaven hath given thee a kingdom, power, and strength, and glory. And wheresoever the children of men dwell, the beasts of the field and the fowls of the heaven hath he given into thine hand, and hath made thee ruler over them all. Thou art this head of gold. And after thee shall arise another kingdom inferior to thee, and another third kingdom of brass, which shall bear rule over all the earth. And the fourth kingdom shall be strong as iron: forasmuch as iron breaketh in pieces and subdueth all things: and as iron that breaketh all these, shall it break in pieces and bruise. And whereas thou sawest the feet and toes, part of potters' clay, and part of iron, the kingdom shall be divided; but there shall be in it of the strength of the iron, forasmuch as thou sawest the iron mixed with miry clay. And as the toes of the feet were part of iron, and part of clay, so the kingdom shall be partly strong, and partly broken. And whereas thou sawest iron mixed with miry clay, they shall mingle themselves with the seed of men: but they shall not cleave one to another, even as iron is not mixed with clay. And in the days of these kings shall the God of heaven set up a kingdom, which shall never be destroyed: and the kingdom shall not be left to other people, but it shall break in pieces and consume all these kingdoms, and it shall stand for ever. Forasmuch as thou sawest that the stone was cut out of the moun- 
tain without hands, and that it brake in pieces the iron, the brass, the clay, the silver, and the gold; the great God hath made known to the king what shall come to pass hereafter: and the dream is certain, and the interpretation thereof sure.

Then the king Nebuchadnezzar fell upon his face, and worshipped Daniel, and commanded that they should offer an oblation and sweet odours unto him. The king answered unto Daniel, and said, Of a truth it is, that your God is a God of gods, and a Lord of kings, and a revealer of secrets, seeing thou couldest reveal this secret. Then the king made Daniel a great man, and gave him many great gifts, and made him ruler over the whole province of Babylon, and chief of the governors over all the wise men of Babylon. Then Daniel requested of the king, and he set Shadrach, Meshach, and Abed-nego, over the affairs of the province of Babylon: but Daniel sat in the gate of the king.

Nebuchadnezzar the king, unto all people, nations, and languages, that dwell in all the earth; Peace be multiplied unto you. I thought it good to shew the signs and wonders that the high God hath wrought toward me. How great are his signs! and how mighty are his wonders! his kingdom is an everlasting kingdom, and his dominion is from generation to generation.

I Nebuchadnezzar was at rest in mine house, and flourishing in my palace: I saw a dream which made me afraid, and the thoughts upon my bed and the visions of my head troubled me. Therefore made 
I a decree to bring in all the wise men of Babylon before me, that they might make known unto me the interpretation of the dream. Then came in the magicians, the astrologers, the Chaldeans, and the soothsayers: and I told the dream before them; but they did not make known unto me the interpretation thereof.

But at the last Daniel came in before me, whose name was Belteshazzar, according to the name of my god, and in whom is the spirit of the holy gods : and before him I told the dream, saying, O Belteshazzar, master of the magicians, because I know that the spirit of the holy gods is in thee, and no secret troubleth thee, tell me the visions of my dream that I have seen, and the interpretation thereof. Thus were the visions of mine head in my bed; I saw, and behold a tree in the midst of the earth, and the height thereof was great. The tree grew, and was strong, and the height thereof reached unto heaven, and the sight thereof to the end of all the earth: the leaves thereof were fair, and the fruit thereof much, and in it was meat for all: the beasts of the field had shadow under it, and the fowls of the heaven dwelt in the boughs thereof, and all flesh was fed of it. I saw in the visions of my head upon my bed, and, behold, a watcher and an holy one came down from heaven; he cried aloud, and said thus, Hew down the tree, and cut off his branches, shake off his leaves, and scatter his fruit: let the beasts get away from under it, and the fowls from his branches; nevertheless leave the stump of his roots in the earth, even with a band of iron and brass, in the tender grass of the field; 
and let it be wet with the dew of heaven, and let his portion be with the beasts in the grass of the earth: let his heart be changed from man's, and let a beast's heart be given unto him; and let seven times pass over him. This matter is by the decree of the watchers, and the demand by the word of the holy ones: to the intent that the living may know that the most High ruleth in the kingdom of men, and giveth it to whomsoever he will, and setteth up over it the basest of men. This dream I king Nebuchadnezzar have seen. Now thou, O Belteshazzar, declare the interpretation thereof, forasmuch as all the wise men of my kingdom are not able to make known unto me the interpretation: but thou art able; for the spirit of the holy gods is in thee.

Then Daniel, whose name was Belteshazzar, was astonied for one hour, and his thoughts troubled him. The king spake, and said, Belteshazzar, let not the dream, or the interpretation thereof, trouble thee. Belteshazzar answered and said, My lord, the dream be to them that hate thee, and the interpretation thereof to thine enemies. The tree that thou sawest, which grew, and was strong, whose height reached unto the heaven, and the sight thereof to all the earth; whose leaves were fair, and the fruit thereof much, and in it was meat for all; under which the beasts of the field dwelt, and upon whose branches the fowls of the heaven had their habitation: it is thou, $\mathrm{O}$ king, that art grown and become strong: for thy greatness is grown, and reacheth unto heaven, and thy dominion to the end of the earth. And whereas the king saw a watcher 
and an holy one coming down from heaven, and saying, Hew the tree down, and destroy it; yet leave the stump of the roots thereof in the earth, even with a band of iron and brass, in the tender grass of the field; and let it be wet with the dew of heaven, and let his portion be with the beasts of the field, till seven times pass over him; this is the interpretation, $\mathrm{O}$ king, and this is the decree of the most High, which is come upon my lord the king: that they shall drive thee from men, and thy dwelling shall be with the beasts of the field, and they shall make thee to eat grass as oxen, and they shall wet thee with the dew of heaven, and seven times shall pass over thee, till thou know that the most High ruleth in the kingdom of men, and giveth it to whomsoever he will. And whereas they commanded to leave the stump of the tree roots; thy kingdom shall be sure unto thee, after that thou shalt have known that the heavens do rule. Wherefore, $\mathrm{O}$ king, let my counsel be acceptable unto thee, and break off thy sins by righteousness, and thine iniquities by shewing mercy to the poor; if it may be a lengthening of thy tranquillity.

All this came upon the king Nebuchadnezzar. At the end of twelve months he walked in the palace of the kingdom of Babylon. The king spake, and said, Is not this great Babylon, that I have built for the house of the kingdom by the might of my power, and for the honour of my majesty? While the word was in the king's mouth, there fell a voice from heaven, saying, $\mathrm{O}$ king Nebuchadnezzar, to thee it is spoken; The kingdom is departed from thee. And they shall drive thee from men, and thy, 
dwelling shall be with the beasts of the field: they shall make thee to eat grass as oxen, and seven times shall pass over thee, until thou know that the most High ruleth in the kingdom of men, and giveth it to whomsoever he will. The same hour was the thing fulfilled upon Nebuchadnezzar: and he was driven from men, and did eat grass as oxen, and his body was wet with the dew of heaven, till his hairs were grown like eagles' feathers, and his nails like birds' claws.

And at the end of the days I Nebuchadnezzar lifted up mine eyes unto heaven, and mine understanding returned unto me, and I blessed the most High, and I praised and honoured him that liveth for ever, whose dominion is an everlasting dominion, and his kingdom is from generation to generation: and all the inhabitants of the earth are reputed as nothing: and he doeth according to his will in the army of heaven, and among the inhabitants of the earth: and none can stay his hand, or say unto him, What doest thou? At the same time my reason returned unto me; and for the glory of my kingdom, mine honour and brightness returned unto me; and my counsellors and my lords sought unto me; and I was established in my kingdom, and excellent majesty was added unto me. Now I Nebuchadnezzar praise and extol and honour the King of heaven, all whose works are truth, and his ways judgment: and those that walk in pride he is able to abase. 


\section{LVIII.}

\section{Tbe JBurning Jiery Jurnace.}

Daniel iii.

NebuchadNEzzar the king made an image of gold, whose height was threescore cubits, and the breadth thereof six cubits: he set it up in the plain of Dura, in the province of Babylon. Then Nebuchadnezzar the king sent to gather together the princes, the governors, and the captains, the judges, the treasurers, the counsellors, the sheriffs, and all the rulers of the provinces, to come to the dedication of the image which Nebuchadnezzar the king had set up. Then the princes, the governors, and captains, the judges, the treasurers, the counsellors, the sheriffs, and all the rulers of the provinces, were gathered together unto the dedication of the image that Nebuchadnezzar the king had set up; and they stood before the image that Nebuchadnezzar had set up. Then a herald cried aloud, To you it is commanded, $O$ people, nations, and languages, that at what time ye hear the sound of the cornet, flute, harp, sackbut, psaltery, dulcimer, and all kinds of musick, ye fall down and worship the golden image that Nebuchadnezzar the king hath set up: and whoso falleth not down and worshippeth shall the same hour be cast into the midst of a burning fiery furnace. Therefore at that time, when all the people heard the sound of the cornet, flute, harp, sackbut, psaltery, and all kinds of musick, all the people, the nations, and the languages, fell 
down and worshipped the golden image that Nebuchadnezzar the king had set up.

Wherefore at that time certain Chaldeans came near, and accused the Jews. They spake and said to the king Nebuchadnezzar, O king, live for ever. Thou, $\mathrm{O}$ king, hast made a decree, that every man that shall hear the sound of the cornet, flute, harp, sackbut, psaltery, and dulcimer, and all kinds of musick, shall fall down and worship the golden image: and whoso falleth not down and worshippeth, that he should be cast into the midst of a burning fiery furnace. There are certain Jews whom thou hast set over the affairs of the province of Babylon, Shadrach, Meshach, and Abed-nego; these men, $\mathrm{O}$ king, have not regarded thee: they serve not thy gods, nor worship the golden image which thou hast set up.

Then Nebuchadnezzar in his rage and fury commanded to bring Shadrach, Meshach, and Abednego. Then they brought these men before the king. Nebuchadnezzar spake and said unto them, Is it true, O Shadrach, Meshach, and Abed-nego, do not ye serve my gods, nor worship the golden image which I have set up? Now if ye be ready that at what time ye hear the sound of the cornet, flute, harp, sackbut, psaltery, and dulcimer, and all kinds of musick, ye fall down and worship the image which I have made; well: but if ye worship not, ye shall be cast the same hour into the midst of a burning fiery furnace; and who is that God that shall deliver you out of my hands? Shadrach, Meshach, and Abed-nego, answered and said to the king, O Nebuchadnezzar, we are not careful to 
answer thee in this matter. If it be so, our God whom we serve is able to deliver us from the burning fiery furnace, and he will deliver us out of thine hand, $\mathrm{O}$ king. But if not, be it known unto thee, O king, that we will not serve thy gods, nor worship the golden image which thou hast set up.

Then was Nebuchadnezzar full of fury, and the form of his visage was changed against Shadrach, Meshach, and Abed-nego: therefore he spake, and commanded that they should heat the furnace one seven times more than it was wont to be heated. And he commanded the most mighty men that were in his army to bind Shadrach, Meshach, and Abednego, and to cast them into the burning fiery furnace. Then these men were bound in their coats, their hosen, and their hats, and their other garments, and were cast into the midst of the burning fiery furnace. Therefore because the king's commandment was urgent, and the furnace exceeding hot, the flame of the fire slew those men that took up Shadrach, Meshach, and Abed-nego. And these three men, Shadrach, Meshach, and Abed-nego, fell down bound into the midst of the burning fiery furnace. Then Nebuchadnezzar the king was astonied, and rose up in haste, and spake, and said unto his counsellors, Did not we cast three men bound into the midst of the fire? They answered and said unto the king, True, $\mathrm{O}$ king. $\mathrm{He}$ answered and said, Lo, I see four men loose, walking in the midst of the fire, and they have no hurt; and the form of the fourth is like the Son of God. Then Nebuchadnezzar came near to the mouth of the burning fiery furnace, and spake, and said, Shadrach, Meshach, 
and Abed-nego, ye servants of the most high God, come forth, and come hither. Then Shadrach, Meshach, and Abed-nego, came forth of the midst of the fire. And the princes, governors, and captains, and the king's counsellors, being gathered together, saw these men, upon whose bodies the fire had no power, nor was an hair of their head singed, neither were their coats changed, nor the smell of fire had passed on them.

Then Nebuchadnezzar spake, and said, Blessed be the God of Shadrach, Meshach, and Abed-nego, who hath sent his angel, and delivered his servants that trusted in him, and have changed the king's word, and yielded their bodies, that they might not serve nor worship any god, except their own God. Therefore I make a lecree, That every people, nation, and language, which speak any thing amiss against the God of Shadrach, Meshach, and Abednego, shall be cut in pieces, and their houses shall be made a dunghill: because there is no other God that can deliver after this sort. Then the king prcmoted Shadrach, Meshach, and Abed-nego, in the province of Babylon.

\section{LIX.}

\section{JBelsbaj3ar's Jfeast.}

Daniel v.

Belshazzar the king made a great feast to a thousand of his lords, and drank wine before the thousand. Belshazzar, whiles he tasted the wine, 
commanded to bring the golden and silver vessels which his father Nebuchadnezzar had taken out of the temple which was in Jerusalem; that the king, and his princes, his wives, and his concubines, might drink therein. Then they brought the golden vessels that were taken out of the temple of the house of God which was at Jerusalem; and the king, and his princes, his wives, and his concubines, drank in them. They drank wine, and praised the gods of gold, and of silver, of brass, of iron, of wood, and of stone.

In the same hour came forth fingers of a man's hand, and wrote over against the candlestick upon the plaister of the wall of the king's palace: and the king saw the part of the hand that wrote. Then the king's countenance was changed, and his thoughts troubled him, so that the joints of his loins were loosed, and his knees smote one against another. The king cried aloud to bring in the astrologers, the Chaldeans, and the soothsayers. And the king spake, and said to the wise men of Babylon, Whosoever shall read this writing, and shew me the interpretation thereof, shall be clothed with scarlet, and have a chain of gold about his neck, and shall be the third ruler in the kingdom. Then came in all the king's wise men: but they could not read the writing, nor make known to the king the interpretation thereof. Then was king Belshazzar greatly troubled, and his countenance was changed in him, and his lords were astonied.

Now the queen, by reason of the words of the king and his lords, came into the banquet house: and the queen spake and said, $O$ king, live for ever: 
let not thy thoughts trouble thee, nor let thy countenance be changed: there is a man in thy kingdom, in whom is the spirit of the holy gods; and in the days of thy father light and understanding and wisdom, like the wisdom of the gods, was found in him; whom the king Nebuchadnezzar thy father, the king, I say, thy father, made master of the magicians, astrologers, Chaldeans, and soothsayers; forasmuch as an excellent spirit, and knowledge, and understanding, interpreting of dreams, and shewing of hard sentences, and dissolving of doubts, were found in the same Daniel, whom the king named Belteshazzar: now let Daniel be called, and he will shew the interpretation.

Then was Daniel brought in before the king. And the king spake and said unto Daniel, Art thou that Daniel, which art of the children of the captivity of Judah, whom the king my father brought out of Jewry? I have even heard of thee, that the spirit of the gods is in thee, and that light and understanding and excellent wisdom is found in thee. And now the wise men, the astrologers, have been brought in before me, that they should read this writing, and make known unto me the interpretation thereof: but they could not shew the interpretation of the thing: and I have heard of thee, that thou canst make interpretations, and dissolve doubts: now if thou canst read the writing, and make known to me the interpretation thereof, thou shalt be clothed with scarlet, and have a chain of gold about thy neck, and shalt be the third ruler in the kingdom.

Then Daniel answered and said before the king, 
Let thy gifts be to thyself, and give thy rewards to another; yet I will read the writing unto the king, and make known to him the interpretation. $\mathrm{O}$ thou king, the most high God gave Nebuchadnezzar thy father a kingdom, and majesty, and glory, and honour: and for the majesty that he gave him, all people, nations, and languages, trembled and feared before him: whom he would he slew; and whom he would he kept alive; and whom he would he set up; and whom he would he put down. But when his heart was lifted up, and his mind hardened in pride, he was deposed from his kingly throne, and they took his glory from him: and he was driven from the sons of men; and his heart was made like the beasts, and his dwelling was with the wild asses: they fed him with grass like oxen, and his body was wet with the dew of heaven; till he knew that the most high God ruled in the kingdom of men, and that he appointeth over it whomsoever he will. And thou his son, O Belshazzar, hast not humbled thine heart, though thou knewest all this; but hast lifted up thyself against the Lord of heaven; and they have brought the vessels of his house before thee, and thou, and thy lords, thy wives, and thy concubines, have drunk wine in them; and thou hast praised the gods of silver, and gold, of brass, iron, wood, and stone, which see not, nor hear, nor know: and the God in whose hand thy breath is, and whose are all thy ways, hast thou not glorified: then was the part of the hand sent from him; and this writing was written.

And this is the writing that was written, MENE, MENE, TEKEL, UPHARSIN. This is the inter- 
pretation of the thing: MENE; God hath numbered thy kingdom, and finished it. TEKEL; Thou art weighed in the balances, and art found wanting. PERES; Thy kingdom is divided, and given to the Medes and Persians.

Then commanded Belshazzar, and they clothed Daniel with scarlet, and put a chain of gold about his neck, and made a proclamation concerning him, that he should be the third ruler in the kingdom. In that night was Belshazzar the king of the Chaldeans slain. And Darius the Median took the kingdom, being about threescore and two years old.

\section{LX.}

The $\boxplus$ Pll of $\mathfrak{L}$ ions.

Daniel vi.

It pleased Darius to set over the kingdom an hundred and twenty princes, which should be over the whole kingdom; and over these three presidents; of whom Daniel was first: that the princes might give accounts unto them, and the king should have no damage. Then this Daniel was preferred above the presidents and princes, because an excellent spirit was in him; and the king thought to set him over the whole realm.

Then the presidents and princes sought to find occasion against Daniel concerning the kingdom; but they could find none occasion nor fault; forasmuch as he was faithful, neither was there any error or fault found in him. Then said these men, 
We shall not find any occasion against this Daniel, except we find it against him concerning the law of his God. Then these presidents and princes assembled together to the king, and said thus unto him, King Darius, live for ever. All the presidents of the kingdom, the governors, and the princes, the counsellors, and the captains, have consulted together to establish a royal statute, and to make a firm decree, that whosoever shall ask a petition of any God or man for thirty days, save of thee, $O$ king, he shall be cast into the den of lions. Now, $\mathrm{O}$ king, establish the decree, and sign the writing, that it be not changed, according to the law of the Medes and Persians, which altereth not. Wherefore king Darius signed the writing and the decree.

Now when Daniel knew that the writing was signed, he went into his house; and his windows being open in his chamber toward Jerusalem, he kneeled upon his knees three times a day, and prayed, and gave thanks before his God, as he did aforetime. Then these men assembled, and found Daniel praying and making supplication before his God. Then they came near, and spake before the king concerning the king's decree; Hast thou not signed a decree, that every man that shall ask a petition of any God or man within thirty days, save of thee, $\mathrm{O}$ king, shall be cast into the den of lions? The king answered and said, The thing is true, according to the law of the Medes and Persians, which altereth not. Then answered they and said before the king, That Daniel, which is of the children of the captivity of Judah, regardeth not thee, $\mathrm{O}$ king, nor the decree that thou hast signed, 
but maketh his petition three times a day. Then the king, when he heard these words, was sore displeased with himself, and set his heart on Daniel to deliver him: and he laboured till the going down of the sun to deliver him. Then these men assembled unto the king, and said unto the king, Know, O king, that the law of the Medes and Persians is, That no decree nor statute which the king establisheth may be changed. Then the king commanded, and they brought Daniel, and cast him into the den of lions. Now the king spake and said unto Daniel, Thy God whom thou servest continuually, he will deliver thee. And a stone was brought, and laid upon the mouth of the den; and the king sealed it with his own signet, and with the signet of his lords; that the purpose might not be changed concerning Daniel.

Then the king went to his palace, and passed the night fasting; neither were instruments of musick brought before him: and his sleep went from him. Then the king arose very early in the morning, and went in haste unto the den of lions. And when he came to the den, he cried with a lamentable voice unto Daniel: and the king spake and said to Daniel, O Daniel, servant of the living God, is thy God, whom thou servest continually, able to deliver thee from the lions? Then said Daniel unto the king, O king, live for ever. My God hath sent his angel, and hath shut the lions' mouths, that they have not hurt me: forasmuch as before him innocency was found in me; and also before thee, $O$ king, have I done no hurt. Then was the king exceeding glad for him, and commanded that they should take 
Daniel up out of the den. So Daniel was taken up out of the den, and no manner of hurt was found upon him, because he believed in his God. And the king commanded, and they brought those men which had accused Daniel, and they cast them into the den of lions, them, their children, and their wives; and the lions had the mastery of them, and brake all their bones in pieces or ever they came at the bottom of the den.

Then king Darius wrote unto all people, nations, and languages, that dwell in all the earth; Peace be multiplied unto you. I make a decree, That in every dominion of my kingdom men tremble and fear before the God of Daniel: for he is the living God, and stedfast for ever, and his kingdom that which shall not be destroyed, and his dominion shall be even unto the end. He delivereth and rescueth, and he worketh signs and wonders in heaven and in earth, who hath delivered Dariel from the power of the lions. So this Daniel prospered in the reign of Darius, and in the reign of Cyrus the Persian.

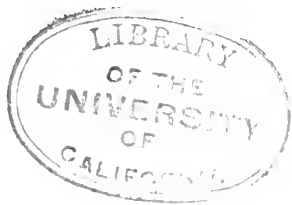


. 
"One of the best series of annotated school texts that have ever been produced."-Dial.

\section{ENGLISH READINGS \\ 16 mo, cloth. Prices net}

\section{PROSE}

Addison: Selections. Edited by EDWARD B. REED, Assistant Professor in Yale University. xxxii $+360 \mathrm{pp}$. I6mo. 80 cents.

Arnold: Prose Selections. Edited, with notes and an introduction, by LEWIS E. GaTES, sometime Professor in Harvard College. $\mathrm{xci}+34^{8} \mathrm{pp}$. $16 \mathrm{mo}$. 75 cents.

Burke: On Conciliation. Edited, with introduction and notes, by DANIEL V. THOMPSON, Teacher in the Lawrenceville School. xlivtr22 pp. r6mo. 30 cents.

Burke: Selections. Chosen, and edited with a full introduction, by BLISS PERRY, Editor of Atlantic Monthly. xxvit298 pp. $16 \mathrm{mo} .75$ cents.

Coleridge: Prose Selections. Selections chosen, and edited with introduction and notes, by HENRY A. BEERS, Professor in Yale University. $\mathrm{xxix}+146 \mathrm{pp}$. $16 \mathrm{mo}$. 5o cents.

De Quincey: The English Mail Coach and Joan of Arc. With an introduction and notes by JAMES MORGAN HART, Professor in Cornell University. $\mathrm{xxvi}+{ }_{1} 8 \mathrm{pp}$. I6mo. 50 cents.

Dryden: Essays on the Drama. Edited by William Strunk, Jr., Instructor in Cornell University. xxxviii+r8o pp. $16 \mathrm{mo}$. 60 cents.

Johnson: Rasselas. With an introduction and notes by OLIVER FARRAR EMERSON, Professor in Western Reserve University. lv+r79 pp. r6mo. 5o cents.

Landor: Selections from the Imaginary Conversations. Edited by ALPHONSO G. NewCOMER, Professor in Leland Stanford University. lix tri6o pp. r6mo. 6o cents.

Macaulay: Essays on Milton and Addison. Edited, with notes, by JAMES ARTHUR 'TUFTs, Professor in the Phillips Exeter Academy. xlix+226 pp. r6mo. 35 cents.

Macaulay and Carlyle: Croker's Boswell's Johnson. The complete essays, with brief notes and an introduction by W. STRUNK, Jr., Professor in Cornell University. With portrait of Johnson on his tour through the Hebrides. xl+192 pp. $16 \mathrm{mo}$. 5o cents.

Newman: Prose Selections. Edited, with introduction and notes, by LEWIS E. GATES, sometime Professor in Harvard University. $1 \times i+228$ pp. 16mo. Buckram, go cents. Cloth, 75 cents.

Pater: Prose Selections. Edited by E. E. HALE, Jr., Professor in Union College. 1xxvi+268 pp. I6mo. 75 cents.

Ruskin: Sesame and Lilies. Edited, with introduction and notes, by ROBERT K. ROOT, Ph.D., Instructor in Yale University. xxviii+r 37 pp. r6mo. 35 cents.

Swift: Prose Selections. Edited by Frederick C. PrescotT, Assistant Professor in Cornell University. xliiit-229 pp. 16mo. 75 cents.

Thackeray: English Humourists. Edited, with an introduction and notes, by WILliam LyON Phelps, Professor of English Literature in Yale University. xii+36o pp. 16mo. 80 cents. 


\section{ENGLISH READING:' (Continued)}

\section{FORMS OF DISCOURSE}

Andrews's Specimens of Discourse. Selected and edited by ARTHUR L. ANDREWS, Instructor in Cornell University. $\mathrm{v}+289$ pp. $16 \mathrm{mo}$. 6o cents.

Baker's Specimens of Argumentation. Chosen and edited by GEORGE P. BAKER, Assistant Professor in Harvard University. r $86 \mathrm{pp} . \quad 16 \mathrm{mo}$. 50 cents.

Baldwin's Specimens of Prose Description. Edited, with introduction and notes, by CHARLES SEARS BALDWIN, Ph.D., Assistant Professor in Yale University. 1+149 pp. r6mo. 50 cents.

Bouton's The Lincoln-Douglas Debates. Edited by A. L. Bou'ron, Assistant Professor in New York University. v+297 pp. r6mo. 60 cents.

Brewster's Specimens of Prose Narration. Chosen and edited by WILLIAM T. BREWSTER, Assistant Professor in Columbia University. $x \times x v i i+209$ pp. $16 \mathrm{mo}$. 5o cents.

Lamont's Specimens of Exposition. Selected and edited by HAMMOND LAMONT, formerly Professor in Brown University. $\mathrm{xxx}+180 \mathrm{pp}$. $16 \mathrm{mo}$. 5o cents.

Lewis's Specimens of the Forms of Discourse. By EDwiN HERBERT LEW IS, Professor in Lewis Institute, Chicago. viii +367 pp. $16 \mathrm{mo}$. 6o cents.

Nettleton's Specimens of the Short Story. Selected and edited by GEORGE H. NETTLETON, Ph.D., Instructor in Yale University. vii+229 pp. $16 \mathrm{mo}$. 50 cents.

\section{POETRY AND THE DRAMA}

Browning: Selections. Lyrical and dramatic poems. With the essay on Browning from E. C. STEDMAN's "Victorian Poets." Edited by EDWARD T. MASON. 257 pp. r6mo. 6o cents.

Byron: Selections. Edited, with introduction and notes, by F. I. CARPENTER, Assistant Professor in the University of Chicago. 1viiit412 pp. 16mo. \$1.oo.

Ford: The Broken Heart. With introduction and notes by CLINTON SCOLLARD, sometime Professor in Hamilton College. xvitr 32 pp. r6mo. 6o cents.

Iyly: Endymion. With introduction and notes by GEORGE P. BAKER, Assistant Professor in Harvard University. exxvit-rog pp. $16 \mathrm{mo}$. 85 cents.

Marlowe: Edward II. And selections from Tamburlaine ThE GREAT, and the POEMS. With notes and an introductory essay by EDWARD T. MCLaughlin, Professor in Yale University. xxi+18o pp. r6mo. 6o cents.

Milton: Minor English Poems. With an introduction and notes by MARTIN W. SAMPSON, Professor in Indiana University. li+ $345 \mathrm{pp}$. r6mo. 6o cents.

Popo: Selections. Edited by Edward B. ReED, Ph.D., Assistant Professor in Yale University. $\mathrm{xxx}+246 \mathrm{pp}$. 16mo. 75 cents.

Shakespeare: Merchant of Venice. Edited by THOMAS M. PARKOTT, Professor in Princeton University. xlit22o pp. r6mo. 35 cents.

Tennyson: The Princess. Edited, with notes, introduction, and analytical questions, by L. A. SHERman, Professor in the University of Nebraska. $1 \mathrm{xi}+\mathrm{r} 85 \mathrm{pp}$. 16mo. 35 cents.

HENRY HOLT \& CO. 34 West 33d Street, New York 378 Wabash Avenue, Chicage

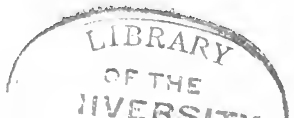





\section{UNIVERSITY OF CALIFORNIA LIBRARY BERKELEY}

Return to desk from which borrowed.

This book is DUE on the last date stamped below.

\section{$21 \operatorname{Jan}^{\prime} 60 \mathrm{GM}$} REC DO DO 


$$
\text { - }
$$




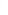




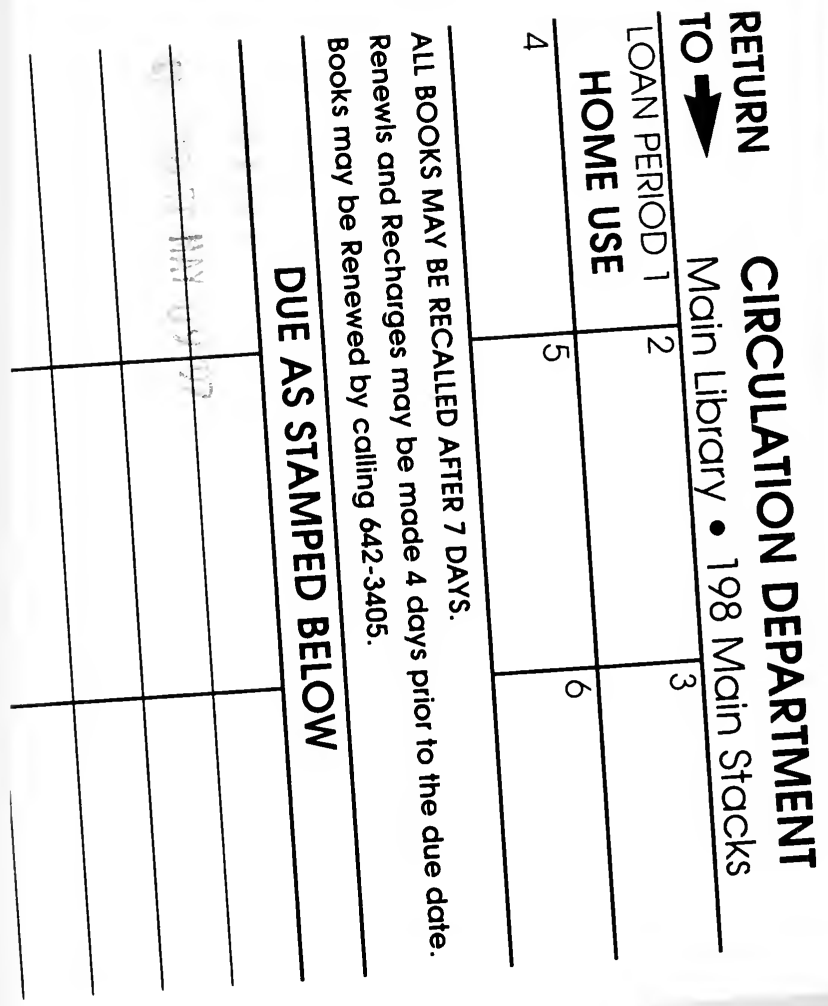


